Salata Oksana

\title{
INFORMATION CONFRONTATION OF NAZI GERMANY AND THE USSR IN THE OCCUPIED TERRITORIES OF UKRAINE (1941-1944)
}

Monograph

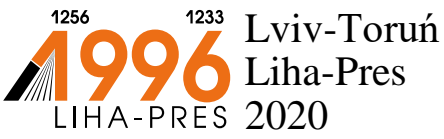




\author{
Published on the recommendation of the Academic Council \\ Borys Hrinchenko University of Kyiv \\ (Minutes № 4 of 28 May 2020)
}

\begin{abstract}
Reviewers:
O.B. Potilchak - Doctor of Historical Sciences, Professor, Head of the Department of Source Studies and Special Historical Disciplines of the Institute of Historical Education of the National Pedagogical University M.P. Dragomanova; O.B. Marushchenko - Candidate of Historical Sciences, Associate Professor, Head of the Department of Historiography and Source Studies, Vasyl Stefanyk Precarpathian National University.
\end{abstract}

\author{
Salata Oksana \\ Information confrontation between Nazi Germany and the USSR \\ in the occupied territories of Ukraine (1941-1944) : monograph. - \\ Lviv-Torun : Liha-Pres, 2020. - 208 p. \\ ISBN 978-966-397-217-6 \\ DOI https://doi.org/10.36059/978-966-397-217-6
}

The research is devoted to revealing the information confrontation between Nazi Germany and the USSR in the occupied territories of Ukraine during the Second World War. The information confrontation of the two states in domestic and foreign historiography is presented; the basic principles of information policy of Nazi Germany and the Soviet Union are revealed; the concept of Nazi Germany's military-political strategy for the Eastern Occupied Territories. The author showed the most modern, for that time, mechanisms, means and methods of dissemination of information among the population, which were used. The information policy of states has become an important element of international policy, so its study is relevant and essential.

The monograph contains a number of author's conclusions, theoretical positions and generalizations that allow to assess the impact of German propaganda on the population of occupied Ukraine. The book is intended for historians, students, and will be of interest to a wide range of readers.

UDC 94(477)«1941/1944»

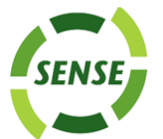

Liha-Pres is an international publishing house which belongs to the category „C” according to the classification of Research School for Socio-Economic and Natural Sciences of the Environment (SENSE) [isn: 3943, 1705, 1704, 1703, 1702, 1701; prefixMetCode: 978966397]. Official website - www.sense.nl. 


\section{CONTENTS}

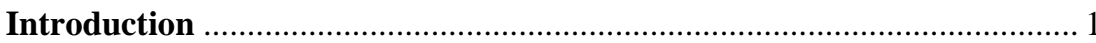

Section 1. The problem of information confrontation

between Nazi Germany and the USSR in historiography

Section 2.1. Ukraine in the Concept of Military-Political Strategy

of Nazi Germany

Section 2.2. Information policy of the Soviet regime on the occupied territories of Nazi Germany

Section 2.3. Technologies and methods for implementing the information policy of both countries in the territory of Ukraine 84

Section 3.1. Media as a mechanism for implementing the information policy of the warring parties

Section 3.2. Propaganda films and theaters during the war years:

their topics, goals, tasks and functions.

Section 4. Information conflict and its influence on the moral-psychological condition of the population in the Reichskommissariat "Ukraine" and in the zone of military administration 169

Conclusions. 197 


\section{INTRODUCTION}

The importance for the modern society is to understand the influence of Nazi propaganda and information policy on the consciousness and moral and psychological state of the occupied territories of Ukraine and implications of this policy.

The information activities of Nazi Germany has been studied by foreign and domestic scholars, including historians. Their writings analyze the process of formation of the National Socialist Party in Germany, its activities in the field of education and public relations, highlight the methods, tools and techniques of information warfare, which were used by Britain, the USA, Germany and the Soviet Union in World War I and II. The structure of Nazi propaganda apparatus was partly studied both in Germany and on the occupied territories of the USSR.

Thus, despite the significant number of works, the activities of certain organs of Nazi propaganda practically was not studied. The aim of this work is to disclose individual structures of the Ministry of Education and Propaganda and the concept of its activities; its implementation in the occupied territories of the USSR.

Studying the events, highlighted in the monographs, there were involved historical scientific methods, particularly in the study of Nazi government advocacy to know and take into account the socio-political, socio-economic, cultural, military development, the relationship with neighbor states, the place in the space of Europe. This system takes into consideration the principle achievements of not only domestic but also foreign historians studying the problem of information policy in the areas considered absolutely German by the Third Reich government. Synthesis method made it possible to synthesize a significant amount of information and its reconstruction on the data, particular situation that has emerged in Germany and Austria during the reign of the Third Reich. The method of synthesis allowed to state that the Nazi regime, which differed in various European countriese, contributed to the development of various forms of cooperation with the Nazi authorities. The statistical method was the basis for receiving, processing, selection and analysis of descriptive and statistical sources, which played a leading role in the structure of sources of this study. It gives an opportunity to determine people in percentage scale, who was really effected by Nazi information policy.

Thus, it should be noted that the Nazi propaganda machine designed and used in 1933-1945 various forms and methods of action on its own population. The main purpose of propaganda services of the Third Reich was 
to get the support of German citizens for the preparation and conduct of the war with the Soviet Union. Thus, the study of the nature and results of outreach impact on the minds of the German population in terms of preparation and conduct of the war was one of the main goals in the activity of the Ministry of Education and propaganda.

The main reception, which Nazi propaganda used in its information policy, is the most primitive sensations that contributed Nazis sympathy to the broad of the masses in Germany. It used all methods to achieve its goals: from cinema to architecture, but radio was given the most important attention of all media. Using propaganda in the mass consciousness of the German people, it implanted hatred so-called "non-Aryan" nations, praising Hitler and German military might.

To sum up, it should be noted that Nazi propaganda in 1933 promoted to the successful stabilization of the regime, which allowed to proceed in time to rapid reorientation of public consciousness. The system of Nazi propaganda, has become one of the pillars of the Third Reich along with the mechanism of state terror, and allowed its leaders to spend more and more radical internal and foreign policy without fear of resistance of the German people. 


\section{SECTION 1. \\ THE PROBLEM OF INFORMATION CONFRONTATION BETWEEN NAZI GERMANY AND THE USSR IN HISTORIOGRAPHY}

The World War of 1939 to 1945 and War of 1941 to 1945 between Germany and the U.S.S.A. are considered to be the key events of the 20th century. They have become an important factor in the change of civilizational values and reference not only for people who have suffered catastrophic losses and destruction, but also for all of humanity. That is why there is an interest of the public opinion to these Wars. It's significant that historical science should study some certain issues and problems. In

Ukrainian historical science and foreign historiography there is a wide range of interests to topics concerning these Wars. It is presented by works of many directions. Certain aspects of the problem seemed to become the subject of the discussion among Ukrainian historians. As a result of this there was published a large number of new documents and materials. There was appeared a lot of research works and papers according to the problem of information policy of Germany and the Soviet Union. As far as a complex study of information policy of the Soviet Union and Nazi Germany, and information confrontation of warring sides according to the informationpsychological impact on the population is absent. It should be pointed out a few questions with regard to studied problem: Why did information and ideological system created by the two States on their own territory begin to confront one another during an active information and ideological influence of the invaders on the population of the occupied territories? Why did using of the most advanced information technologies and methods of dissemination of information of 20-s of the XX c. seem to be not effectively to satisfy the desire of the Nazi leadership and realize plans of aggressive financial official quarters of Germany?

The theme of information confrontation between Nazi Germany and the Soviet Union in 1941-1945 is a new one because of notions "information technology", "informational-psychological influence" weren't used by historians in the 1950-1980-s. The vast majority of historians and politicians of the Soviet Union believed that the USSR became the winner in the World War of 1941-1945 only due to people who worked in the rear, powerful 
weapons and the patriotism of the soldiers who were ready to give his life for the Motherland. In this context the value of the information policy of both countries practically wasn't studied. by Soviet historians. It belongs to the problem of the means and mechanisms of the information-psychological impact on the population. Soviet historians studied mainly an ideological propaganda among the population at the head of the Communist Party as an organizer of the struggle against German fascist invaders. That's no doubt, that the Communist Party really played the role of an active Organizer: It was also conducted by the Government's information policy which had to affect the consciousness and behavior of the personnel of the Red Army and the population of the occupied territories.

At the end of 80-s of the XX century Soviet and foreign historians began to analyze the methods and mechanisms of Nazi's in the period of occupation. As far as a policy and activity of the Soviet military leadership according to propaganda and a problem of information confrontation of both countries Soviet historians didn't broach the question. Such analysis could have led to the conclusions that the Soviet Union and Nazi Germany had informational tools and means of equal worth in the period of war (Коваль 1988).

Due to these facts it's important that native historical science should give a deep study of information confrontation between two totalitarian States on occupied territories of Ukraine, Belarus and Russia during the World War of 1941-1945.

At the end of 1980-s a famous Ukrainian historian M. V. Koval began to investigate Nazi propaganda as a factor of impact on the moral state of the population of the occupied countries, including Ukraine. Studying the sociopolitical life of the Ukrainian population he researched fascist propaganda and its basic principles. One of the most important achievements of his work was the study of the methods of Nazi propaganda which were to survey moral values and the Soviet outlook created by the Bolshevik Party. M. Koval investigated the activity of German popularization apparatus: ministries, departments, military propaganda departments. He carried out detailed review of the mechanisms of popularization effects on the local population. In his opinion "liberalism" which was demonstrated by the German occupational authorities in creating of local self-government bodies was extremely a powerful propaganda move. Nazi authorities found supporters among the local population who became to collaborate with local self-government bodies. Ethnic Germans (Fol'ksdojche) happened to be the background of that policy that created favorable conditions for them to work. The author wrote that an active information policy of Fol'ksdojche had provided a cooperation with the Gestapo, police and other German institutions. While studying the 
socio-political life of the Ukrainian population during the German occupation M.Koval concluded that Nazi propaganda seemed to be inefficient one. In spite of activity of Nazi informational propaganda a large part of the population didn't collaborate the cooperation with Nazi authorities. Moreover from spring 1942 people actively started cooperating with the Resistance (movement against Germany during World War II). Analyzing the moral and psychological state of the population, the researcher evaluates its activities from the positions of the Communist Party (Коваль 1999).

The impact of Nazi and Soviet propaganda on the population of the occupied territories as information weapons is a subject of study of historians A. Ivlev and A. F. Udenkov. Their work is devoted to the political activities of the Communist Party on the occupied territories of the USSR during 1941-1944. These historians offer a huge amount of actual material that illustrates the psychological impact of Nazi propaganda on the inhabitants of the occupied territories of the USSR. It should be noted that while considering the methods and techniques of Soviet propaganda the authors didn't study profoundly the mechanisms of Nazi propaganda. Generally materials of their work give the possibility to compare and analyze German and Soviet advocacy activity (Ивлев 1988).

The problem of informational policy of both totalitarian states and the advocacy structure of the Third Reich Government wasn't the special subject of soviet historiography. Some aspects of this theme were studied by historians in the 80-90-s of the XX c. So the advocacy of Nazi Germany was studied in the works of historian D. A. Volkogonov, His works are devoted to information-ideological confrontation of the USSR and the West during the Cold war. "The author of the study showed that the Nazi propaganda techniques and methods had put into practice of Western Europe countries and the United States after the end of the World War II. It formed a bipolar world. The main aim of these studies was evidence of direct borrowing of NATO countries methods and techniques of Nazi propaganda" (Волкогонов 1983).

Another Soviet historian Y. Orlov paid attention to the methods and principles of propaganda of the Third Reich on the base of profound analysis. The scientist denied on the myth that Nazi propaganda had been a perfect and professional one. The historian also criticized the principles of Nazi manipulation by people. In his work "The collapse of the Nazi-fascist propaganda during the War against the USSR" Orlov reveals the lie "technique" and the ideology of dictatorship, violence and racism. The scientist deals with the mechanisms of psychological warfare which Hitler fascism led against the peoples of the world. However, debunking the propaganda mechanism of Nazi Germany, the author doesn't pay attention to 
the research of the advocacy popularization structure of the Nazi apparatus (Орлов 1985).

Studying an ideological and a political activity of the Communist Party of Ukraine during the War of 1941-1945 between Germany and the U.S.S.R. P.Grigorovich and other historians covered propaganda methods of Nazi Germany and ways of confrontation by the side of the Soviet Government (Григорович, 1976). The main idea of these works is considered to base on the conclusions that the Communist Party was the only consolidate power in the difficult conditions of the war to have directed the activity of all authorities and ordinary citizens by using this modern (for the time) the methods of ideological influence.

At the beginning of the 1990s when Ukraine became an independent state native historians began to develop new directions in studying of the events of the World War II dealing with not only the activities of the Communist Party but also the activities of the OUN, UPA on the occupied territories. Ukrainian researchers had to investigate deeper this problem to coordinate their researches with works of foreign historians. Working not only with national archives and materials but also with the documents being published abroad Ukrainian historians began to take an active part at international conferences presenting new documental materials relating to the problems of the information space and information of propaganda.

Due to the research of new archival materials and documents the World familiarized with scientific papers on various aspects of advocacy of Nazi Germany including the temporarily occupied territories of Ukraine. Among these works there are some representatives of modern scholars: A. Kuchma, A. Nikolajce, and G.Vetrov, A. Potil'ak, P. Rekotova, Y. Voloshin, and their Russian colleagues: MSemiragi. V. Tsymbala and G. Voronenkovoi.

Important aspects of outreach policy of Nazi Germany were considered by native historians Y. Vološinim and A. Lysenko. Examining the situation of the Ukrainian Orthodox Church in the years of the Nazi occupation Y. Voloshin reviewed also the attitude of Nazi Germany to the Orthodox Church. Nazi attempts connected to the policy of collaboration among the local population by means of religious freedom propaganda is dealt with by Voloshin. In his work a scholar analyzes the anticommunist activities of the Orthodox Church in the western regions of Ukraine. He concludes that the clergy of the Orthodox and Catholic churches didn't not only justify an aggressive policy of the Hungarian Government during the World War II but also provided financial assistance to conduct their policy (Волошин 1997).

The work of A. Lysenko is devoted to the activity of religion's authorities on the occupied territories of Ukraine during the Nazi-Fascist occupation. 
The author coves the problem studying various aspects of the situation of the faithful and Orthodox Church: the position of the Orthodox Church to the Nazi-Soviet war, changes connected with occupation, a religious life of Ukrainian people on occupied territories that was intensified due to the special policy of the Nazi authorities. In the first months of the occupation there was renewed of the Church and the churches according to the goals of Nazi occupational administration to provide order and strengthen its position. O. Lysenko demonstrated the cooperation of the Ukrainian clergy with the occupying powers, and patriotic activities of religious figures who helped to survive the Jewish population against the Nazi regime. The religious question in the practice of Ukrainian nationalism is thought to be an important matter of his research Лисенко, 1998. As far as the study of the ideological aspects of the initial stage of World War II they present the most attractive pages of his work (Лисенко 2002).

It's important for the research of the ideologically-advocacy Nazi Germany on the occupied territories of Ukraine to analyze the work of Ukrainian historian V. Potilcaka. His scientific papers cover the ways of exploiting the occupied civil population labor of Ukraine by the leadership of the Third Reich. O. Potil'čak vividly reveals the propaganda activity of the German administration to provide to convince the local population to work for Germany by labor power. It should be pointed that some part of population agreed to work in Germany. The author concluded that there were people who were against Soviet power., and who really believed in the future of Ukraine under the tutelage of Germany. These facts proved to be arguments that the Nazi propaganda was rather effective at some stage of the ocupation (Потильчак 1996, 237).

Nazi Germany waited for assistance and support in the creation of their own State from a large part of Ukrainians who didn't satisfy the policy of the Soviet power on the territory of Western Ukraine, This idea of independent state of Western Ukraine attracted a significant number of Ukrainians and urged them to cooperate with the occupying authority. This question deeply was studied in the research of the historian A. Bolânovs'kogo. He analyzed activity of the self-determination movement in Ukraine. The author also reached certain conclusions. Firstly, the German leadership, despite his propaganda, never supported the intentions of the Ukrainian nationalists to create its own army, and especially the State. The existence of the same Division "Galichina" is known to have a little big impact on population not only of the District of Galicia, but also on the population of Rejhskomisariatu "Ukraine", and the zone of military administration. A. Bolanovs'kij noted that the activities of the Division "Galichina" in the context of Ukrainian national 
liberation movement had a moral and political influence on the population of Ukraine and had German propaganda to weak (Боляновський 2000).

The work of the famous Ukrainian historian V. Serhiychuk, dedicated to Ukrainian national liberation movement to restore and strengthen the Ukrainian State on the occupied territories. In studying the author collected materials and documents about the leading mobile groups of OUN. They revealed the politiics of Nazi occupation Administration on the territory of Ukraine "Rejhskomìsariatu" and the military administration. Thanks to the records of the OUN mobile groups the reaction of the local population to Nazi information and advocacy policy seemed to be a very valuable factor in this study. Serhiichuk carried out the facts that a part of the local population supported the "OUN's underground" but Nazi propaganda did not give them the opportunity to join to this national liberation movement (Сергійчук 2005).

In modern Ukrainian historiography there is studied the problem of the influence of the German propaganda on the socio-economic and cultural development of the occupied lands. The work of 1 historian I. M. Gajdaburi. "Exploring the Cultural and Educational Development of the Population of Ukraine "Rejhskomìariatu", and the Zone of Military Administration", the author stresses that with the invasion of Hitler's army, most theaters began to work because the actors and Directors believed in the possibility of the revival of Ukrainian culture (Гайдабура 1998) "In this case Nazi propaganda emphasized the author, - worked quite effectively, but only in the first months of the war". The value of this research is dealt with studying not only the negative sides of cooperation of Ukrainian theatrical intelligentsia with the German administration. On other side, a lot of actors had the opportunity to work. And they tried to convey Ukrainian beauty and peculiarity of Ukrainian culture through theatrical performances to develop the State Ukrainian traditions and art.

Applying innovative approaches of modern historical science historians. A. Skorobagatov and S.D. Gal'čak investigated the question of the influence of the German propaganda on soldiers of the Red Army and part of the population of the occupied territories. Considering the Kharkiv region and Podolia in the period 1941-1944 and revealing features of the life of the Ukrainian population in the German occupation these scientists analyze agitation-propaganda activities of the occupying administration. A. Skorobagatov explores the process of establishing a "New Order" when the cruel policy of the Nazis caused a complete breakdown of their outreach (Скоробагатов 2004). Gal'čak, studying documents and materials that affect the policy of the German invaders on the use of the "Eastern workers" for the strengthening of the Third Reich presents the histirians and the public opinion with separate propaganda materials that the 
population of Podillya volunteered to go to Germany and work for the sake of the great future of new Europe. The author also reveals a picture of the horrific life and work of Ukrainian workers in Germany through the memories of most workers. Unfortunately, the question of the impact of Nazi propaganda wasdealt with the context in studying of general problems (Гальчак 2004).

At the beginning of the new Millennium Ukrainian historians focus their attention on the moral and psychological state of the personnel of the Red Army, and the population of the occupied territories. Scientist's goal is to understand the motives of men's behavior in period of occupation and a total war. Having an idea of what is the "information policy" and "information space", scientists examine the advocacy of Nazi Germany as a complex of measures aimed at the destruction of a significant part of the population of Eastern Europe. In this context attention is attracted by the work of "Renaissance Rose sharply on the German-Nazi occupation policy in the sphere of education". Its author is J. Tarnawsky. There were studied the common problem of organization and activity of secondary educational institutions on the occupied territory of Donbass and the issue of the implementation of education policy, which was aimed at the humiliation of the Ukrainian people and its destruction. Exploring the politics of Nazi power on the territory of the Donetsk region he states that an occupying power in order to reduce the intellectual level of the Ukrainian youth purposefully undermined the education system. Through its facilitation and later complete elimination, Nazi Administration tried to deprive citizens of cultural traditions and turn them into obedient workers (Тарнавський 2005, 125).

Studying the moral and psychological state of the soldiers of the Red Army and the mood of the population at the beginning of the Nazi-Fascist occupation, Ukrainian historian. Y. Nikolaêc' notes that part of the population did not want to go to defend the Soviet country because of being declared "enemies of the people". But not all of the population believed the German propaganda began a coperation with Nazi regime. Y. Nikolaêc' notes that a large part of the population took waiting position and observed information from the fronts. Analyzing the moral and psychological state of the population, he concludes that with the progress of the war, the attitude to the Nazi occupation administration and the Hitlerite regime in General dramatically changed as a result of the victories of the Red Army (Ніколаєць 1999).

To present the disclosure of the complete picture of the information policy of Nazi Germany is important to analyze the work of the famous Ukrainian historian B. Chernyakov. While studying the history of journalism he had devoted a considerable attention to the investigation of periodicals during World War II. It was completed by the newspapers and magazines which were released on the 
occupied Nazi army. Scientists analyzed the conditions that it was formed when the press began functioning on the territory of Ukraine "Rejhskomisariatu" and in the area of military administration. Exploring the base instructions of the periodical printed devices, the author had defined the level of significance of the press for the Nazi occupation authorities and wrote that the press seemed to play the leading role in the Third Reich (Черняков 2006, 52).

A modern historical science demands that the problem of studying such a common phenomenon as collaboration which was the result of a strong information policy of the Nazi Government on occupied territories should be studied by native and foreign historians. There is the obvious fact that a certain portion of the population was to collaborate with the new authorities under the influence of propaganda existed by the Nazi Germany on the occupied territories. For a long time the Soviet historiography has attempted to avoid coverage of the matter. Let us not forget about the fact that everyone who worked on the occupied territories unambiguously called "enemies of the people", although the people ought to work for different reasons. This fact made them cooperate with the occupying powers. To understand this important matter, comprehend the phenomenon of collaboration helped the work of V. Šajkan "Collaboration on the territory of Rejhskomìsariatu" "Ukraine"“" and "War Zones in World War II". The theme of her research is closely linked with the problem, which is considered in this paper, because the cooperation of the population of the occupied territories with the occupational regime was directly dependent on the quality of the Nazi information policy. The researcher determined the objective reasons of collaboration among the population and the extent of the impact on this phenomenon of agitation-propaganda work by the German occupation Administration (Шайкан 2005, 234).

Historian O. Lysenko suggests that new conceptual approaches should be adopted in studying of World War II. He singled out such an important trend in the research of native historians as social history. Having examined the social aspects of the occupation of the Ukraine he explored the social policy of the German Government and the reasons of collaboration of all strata of the Ukrainian population. The scientist critically notes that: "the Bolshevik government, the Nazi authorities did not propose for the local population fundamentally new ways of living. Agitation-propaganda campaign led by the German authorities on the occupied lands of Ukraine was carried out only in order to obtain voluntary labor for the economy of the Third Reich and to force peasants to work in collective farms. Analyzing propaganda campaign of Nazi power O. Lysenko concludes that the system of collective responsibility set by the Nazis was in not much different from the Soviet collectivism (Лисенко 2007, 7) 
The work of V. Grineviča,is devoted to Stalin's policy according to national minorities during World War II. Examining the overall problem the author highlights the advocacy activities of units of the Wehrmacht being directed at the education of soldiers of the German army with an aim to bring up men with ideas of racial superiority. V. Hrynevych states that the system of officer's education was introduced with the use of such tools and techniques as: lectures, films, radio shows, carefully designed leisure park. The military leadership used the reports prepared the Nazi theorists (Гриневич 2005, 184).

Ukrainian historians went further in the study of indicated problems. There was published a good deal of works devoting to Nazi propaganda on occupied territories of Ukraine. In particular the problem of Nazi propaganda in occupied Kiev was studied by M. Mykhaylyuk. In her papers there were covered the tools used by an occupying power to influence on the population of the city. Among them: radio-cinema-propaganda, newspapers and magazines that had printed on the territory of Ukraine "Rejhskomisariatu". The work is a very valuable and an important one. But that the researcher sees propaganda as an instrument which was operated by Hitler's power structure for the implementation of the impact on the population of the occupied territories of Ukraine. However the author has not explored propaganda as an element of global information policy of Nazi Germany (Михайлюк 2005, 288).

The question of the impact of Nazi propaganda on the personnel of the Red Army and the population of the occupied territories through the means of propaganda created by Vermahtom, explored the Ukrainian historian D. Titarenko. Studying the reports of German battalions of propaganda the scientist revealed the system their activities on the occupied territories of Ukraine, the methods used by them, as well as determined the degree of impact of their activities on the population of the occupied territories of Ukraine (Титаренко 2005, 167). Unfortunately the author of the study does not illuminate the advocacy of German battalions propaganda as part of the whole of the information policy of the Third Reich on occupied territories (Титаренко 2010, 480).

A great attention must be paid to the research of Russian, German, British and American scientists-historians and Essayists. The subject of their works is connected with the World War II. They introduced important captured documents, and the publication of bibliographic research and memoir literature to scientific circulation We are interested in analyzing of studies devoting to the themes of our research: "Information confrontation between Nazi Germany and the Soviet Union in 1939-1945"; "Information technologies applied by the Governments of both countries to influence the consciousness and the moral and psychological state of its own population and the population of the adversary". 
The problem of informational influence on the awareness of the population of the occupied territories during the World War II virtually was studied' in the period of the Soviet Union without introducing such notions "information technology", "German information space", "tools and mechanisms of formation of information space". Despite the fact that in the USSR the mechanisms and means of propaganda influence on the population have been studied by experts of special services and administrations, historians studied mainly ideological propaganda among the population with the priority that demonstrated the advantages of Socialist life. Partially historians covered the methods and mechanisms of agitation and propaganda used by Nazi Guide and the German occupation authorities.

In comparison Germany there is another situation. There the NSDAP came to power and began active opened work presented by the Ministry's management of propaganda and education. This authority developed the mechanisms and means of influence on the population and the personnel of the army. So much attention to the means of information impact was caused by the horrible defeat in the period of the World War I. The first study of information policy of the Third Reich is known to have appeared in 60-70s of the twentieth century.

During this period there were published works by Soviet historians which had analyzed occupation policy of the Nazi army on the territories of the U.S.S.R. The works of D. Melnikov, L Black, soviet writer I..Ginzburg reveal the effectiveness of Nazi propaganda. In his work "Those meetings" ("Potustoronnie vstrechi") I. Ginsburg emphasized the personal responsibility of the leaders of the Third Reich according to the policy that they carried out on the occupied countries of Europe and in the Soviet Union. It coves the political priorities of Nazi Germany and the consequences of propaganda which was carried out on the occupied territories (Гинзбург 1990). L. Black, exploring the Nazi apparatus dictatorship and its advocacy activities, concluded that Nazi Germany as a totalitarian state became a special form and control over all spheres of social and political life. It had been installed only the social democratic party. The work of 1 . Black is considered to be the first to have described the mechanisms of influence of the person or group of persons on the society in general and Germany in particular (Черная 1992).

The attempts to establish an information blockade for the population of Germany in the context of information policy of Nazi Germany was studied by famous Russian historian I. Bezimensky. In his work "Third front. The Secret Diplomacy of the World War II" the author reveals the period of the military rise of the Third Reich and the true intentions of major European countries and the United States that arose in the early $30 \mathrm{~s}$ of the 
twentieth century. In his research the scientist tryed to uncover the information policy of the Western powers that sought the hands of Nazi Germany to solve the problem in Eastern Europe (Безыменский 2003).

In the common work on the history of national socialism widely reported the ideology of German fascism and its ideological. In the biggest uzagal'nûval'nomu a study of German fascism - monographs A. Galkinanational-socialist ideology and its implementation in the information policy of the Nazi Germany are examined in more detail than previous the works of Soviet researchers. The author reveals the essence of the outreach activities of the National Socialist Party in Germany and its plans for the occupied territories of the USSR. As a research scientist for the first time were analyzed socio-psychological bases and socialist system component of Nazi ideology (Галкин 1967).

It was stated above in the works of Soviet and modern historians the subject of studying is an ideological propaganda which was directed on the population of their own country and the armies. Unfortunately the concept of "information space" has not yet become the object of attention of scientistshistorians who have studied the problem of the World War II and great patriotic wars. The propaganda of the USSR and Germany seemed not to research by native historians as full information policy aimed at the population and the armed forces of the enemy in the 80-90-ies of the twentieth century.

In the 1960-1970s works and papers of foreign historians due to the information confrontation and the mechanisms and means of popularization of its influence became the subject of scientific investigations.

The first works on the territory of Western Europe, which also analyzed information policy of the Third Reich, were written by direct participants in the events of World War II: members of the Nazi Government, officials of the Ministry of propaganda and education in Germany in the 40-50-ies of the twentieth century. Western European historians and publicists started studying the events of World War II, using material collected and saved by the war event's participants of 1939-1945. It should be noted that most of these researchers had accessed to the unknown Soviet historians materials which gave an opportunity to witness the events of World War II from a position of the observers. On the other hand the European historians didn't know about a true situation on the front and in the rear as the Red Army and Wehrmacht. Despite this fact, the period taken in foreign historiography of an extremely important place. The German, British and American historians have even shared the writings of more deeply explore information policy in Germany and the Soviet Union, and their interrelationship and opposition. There were 
works where priority was given to the investigation of certain aspects of socio-political, and socio-economic life of the population of the USSR being under Nazi occupation. Unfortunately there is no the generalized study in historiography's heritage which would belong to the question of German information space and information confrontation of the USSR and Germany as a separate scientific theme. For a long period most this theme wasn't the subject of the historical literature in order to give another characteristics of the occupation period in the USSR and other countries occupied by Nazi Germany. Some works of German historians A. Hadamovsky, N. Muller, P. Longeriha, R. Koela, etc. are thought to present the literature that had showed the effectiveness of information policy in Germany. It should be noted that German historians play an active role in studying this theme. If we analyze 10-th volume's edition of the series "The German Reich and the World War II" we can know about the process of creating the National Socialist Party in Germany and unprecedented in the history of the world system of state manipulation of the human masses in the history, and the information space being controlled by Nazi leadership Accordingly a special attention was paid to the disclosure of questions concerning the preparation of Nazi Germany to attack the Soviet Union, and the formation of system for informational and psychological warfare against the Red Army and the civilian population. According to works of the historians the Nazi propaganda was supposed to shake the morale of the Red Army, and promote the disorganization of the Soviet rear and organize a work of the local population on the occupied territories A final goal was to form new stereotypes of Soviet citizens on the base of Nazi ideology.

Propaganda policy of Nazi Germany,and its influence on the psychological state of the population in the period of the temporary occupation of Ukraine and Belarus was studied by the next Western European scholars and American historians D. Amstrong, G. Dzouet, I. Kersou, P. Longerìh, J. Fest, Balfor, Soesman, Vìperrman and others. A characteristic feature of their works is the widespread use of documents of the Nuremberg process, archival materials of European countries, and the participants' memories of the Soviet partisans and members of Ukrainian national liberation movements. However, consideration of the features of the occupation regime established by the Nazis on captured territories became the main subject of historiography of World War II. A lot of historians investigate Nazi propaganda mainly in the period of formation of the National Socialist Party in Germany. The informational propaganda of the Third Reich directed on the population of the occupied territories of the USSR separately is not detached in German historiography. This side of the activity 
of the Nazi leadership was considered only in the general framework of the investigations.

The first step in examining of coming of the National-Socialist Party in Germany was the work of an eye-witness of the events Goebbels O. Hadamovskì. Being a direct participant and witness of the activity of the Third Reich as a specialist-an expert of the formation of public opinion he explored mechanisms and technology influence by the means of propaganda on the population of Germany. Such activities caused O. Hadamovskì to carry out research in this area to determine its effectiveness. He concluded that an experience of exploring the propaganda techniques of the NSDAP was a very important to study by all historian scholars. He came to the conclusions that the propaganda and differentiated use of force had to supplement each other. They never are absolute opposites. The use of force should be a part of the propaganda. This principle, according to O. Hadamovskì, was ignored by the National-Socialist Party after coming to power in Germany (Hadamowsky 1933). His works gave a great number of materials for the study of the themes for researches and opened the way to study such a global modern weapons as information policy.

Many studies were carried out on the basis of a large array of archival materials, documents and diaries of the direct participants in the events of the World War. The work of J. Amstronga "Soviet Partisans in World War II" should be considered an important one in this context. This work was written on the basis of numerous documentary materials: reports and messages of Nazi political and military leaders and officials of the occupation administration and the Wehrmacht. The researcher highlights the activities of the propaganda departments of the Wehrmacht against the Soviet partisans on the occupied territories. According to the point of the historian view the activity of Soviet partisans really caused the influence of propaganda on the population to weak and forced occupation authorities to use all new techniques of influence (Armstrong 1964, 2007). Armstrong wrote about the nature and significance of the combative partisan movement during the World War II. Historians of Germany and the USSR concluded different statements in estimating of "spontaneous" patriotic reaction of the population, and of courage and organizational abilities of local party leaders who had guided the activities of the Central Party. His work is the first attempt to bring clarity on these issues through regular research of the large number of German and Soviet documents being presented at the end of the World War II (Armstrong 1964, 2007).

The plans of Nazi Germany for capturing the living space of the USSR was dealt with famous German historian N. Müller. While focusing on the 
main problem of the role of the Wehrmacht and its governing bodies in the implementation of the fascist occupation regime on the Soviet territory the author reveals the reason for the breakdown of the plans of the German occupation administration and, as a result, the collapse of the occupation regime. An important part of the work is devoted to the consideration of the matter of the failure of the attempts of fascist occupation authorities to create Nazi regime by political and social demagogy and information policy. The author has managed to uncover the true role of the Wehrmacht in the planning and implementation of occupation policy on the occupied territory of the USSR during the World War II.

Analyzing the individual aspects of the information policy of Nazi Germany Mueller has made conclusions that the political goal of Germany was to eradicate Bolshevism and Communist ideology and Soviet State. In solving the economic problems of the Third Reich the Nazis planned to convert the captured territories in South-Eastern Europe in agro-raw appendage Grand Germany's economic sphere and an important market for its industrial products (Мюллер 1974).

A great interest of German researchers caused to the activities of institutions of the Nazi popularization system created by the NSDAP after the coming to power. German historian P. Longerih explored the advocacy of the foreign Department of the Ministry of Foreign Affairs and the problem of using of radio by the Nazi leadership. He analyzed the structure of the Ministry of Foreign Affairs defining the place and role of the Department in the information policy of the Third Reich Longerih revealed the methods and technologies of influence on the population of Europe by means of the radio broadcasting and periodicals. The author observed that the radio had been used by the leadership of the Third Reich with the aim of psychological processing of the population and had become one of the main methods of Nazi information policy (Longerich 1987).

An important aspect of the research of the historian is to study the activity of the punitive machine of Nazi Germany, and the role of Himmler in the party hierarchy, and organization of National Socialist terror and destruction of the Jews. The realization of the plans according to the destruction of the population of the occupied countries that did not relate to the "Nordic race" started existing after the beginning of the World War II. P. Longerih covered the stages of formation of the consciousness of Himmler in terms of development and consolidation of the National-Socialist ideas. He presented compelling evidence that Himmler had become cynical, cold-blooded, creator and performer of the oppressive policy of the Reich. A massive punitive campaign in Poland, the Soviet Union and other countries, creating the vast 
network of concentration camps, mass deportation of the population for slave labor in Germany were evidence of the policy. The most terrible crime Himmler, according to researcher became the Holocaust, which had destroyed more than 6 million people of Jewish nationality (Лонгерих 2008). Unfortunately, in the context of these studies, P. Longerih doesn't not consider the information policy of Germany as one of the global causes of loss of political authority of Germany in Europe.

R. Koel is one of European researchers who studied the decrees of the Nazi Government to create new German colonies in the occupied eastern territories and to form a new peasantry of Folksdoiche. The study of these documents helped to define what role the Nazi Government according to departure of German peasants on the occupied territory. One of the following decrees was the beginning of the brutal directives and orders which denoted German policy on the occupied territories of Ukraine. R. Koel made the conclusion that the results of such decrees were provided by a juxtaposition of different peoples on the occupied territory. It is significant that $\mathrm{R}$. Koel managed to have analyzed the propaganda being conducted by an occupying power among the rural population, and its impact on the consciousness and behavior of peasants in the first months of the occupation (Koehl 1957).

The structure of the popularization of the apparatus of the Wehrmacht and his activity among enemy troops were studied by a military historian A. Buhbender. His works are devoted to the study of Nazi leaflets distributed in the years of the World War on the fronts and in the field of fighting (Buchbender 1974).

In his work he noted that the first phase of the war propaganda against the Red Army had the euphoria character connected with the success of Nazi army and the destruction of Red army moral and psychological state at the beginning of war. The historian stated that the leadership of Nazi Germany had understood that propaganda was a powerful tool for carrying out the desired policy. That was why a great attention had been paid to the activity at the front. Significant is the conclusions that The preparation of the propaganda war against the Soviet Union at the same time seemed to have been existed and have been trained a long before the events. April 1, 1939 when the Supreme command of the armed forces - RCC (Oberkommando der Wehrmacht - OKW) was created by the "Wehrmacht-propaganda". On the eve of the attack on the Soviet Union Ministry of propaganda organized "General Oriental Space authority" (Generalreferat Ostraum) headed by Eberhardom Taubertom, It is often referred to as well as Organization Vìneta which was transformed into the Department of the East (Ost Abteilung) in 1943. These institutions became the main centres of 
the Organization at the forefront of propaganda front line among "Eastern volunteers" (Buchbender 1974).

German historians G. Forsterch and G. Snitter investigated the activities of Prus-German general staff in 1640-1965 including its work in the conditions of World War II in the context of this problem. They regarded the activities of the leadership of the Wehrmacht and its concept of war. G. Snitter defined the role of propaganda in German acting army among the soldiers of the Wehrmacht and the troops of the enemy (Ферстерч 1966). The scientist concluded that the Department was in charge of all the activities that had an impact on the society of the Third Reich and its borders. G. Snitter focused on three main directions of information policy of the Wehrmacht: the propaganda among the German population and military personnel; propaganda in the army; "the propaganda against the enemy", i.e. the impact on the armed forces and the civilian population.

Tthe works of Australian historian M. Balfora devoted to the study of advocacy and informational propaganda of Germany on the eastern front are considered to have important documental materials. In particular the author revealed a scheme due to Ministry of the Eastern occupied territories and of the Wehrmacht on the occupied territories of the USSR was built (Balfour 1979). It is important to cover the external information policy of Nazi Germany in 1939-1945. There is studied a foreign propaganda aimed at the countries of Western and Eastern Europe by this historian.

American researchers E. Dgovet and O. Donell studied ideological conception of A. Hitler and the National Socialist Party advocacy among the population of Germany. They distinguished the basic principles of Hitler's propaganda ideas recommended by him. G. Dgovet stated that such advocacy had helped the NSDAP power to grab and control almost all spheres of life of German society for short term (Jowett 1992).

A comprehensive information policy of Nazi Germany was researched by English scientist I. Kersou. Having studied activities of A. Hitler the author had examined the Nazi propaganda as a system. To I. Kersou's mind the idea and the image of the new State was persistently implemented in the life of society and the consciousness of every German citizen. The method proved to be a very effective for psychological treatment. Examining the documentary sources I Kersou presented facts that had proved the effectiveness of psychological processing of large parts of society especially the middle class and the peasantry. In his work the scientist focuses on the fact that under the influence of information policy conducted by the Ministry of propaganda a significant number of peasants teamed up and created an organization of "peasants Union" which took the responsibility of agricultural production for the Third Reich (Кершоу 1997). 
The agitation activity guide of the National-Socialist Party touched the working class. Carrying out this question American historian V. Soesman showed that A. Hitler and Nazi Germany realized the program which was directed to the workers as the main driving force in formation of Third Reich. The workers were said about a new social policy connected with the occupation of eastern territories. According to the researcher's work oratory art of A. Hitler and Goebbels gave just shocking t results in the presence of a huge audience. In his opinion the development of broadcasting was expanded not only on the territory of the Germany but also in the territories of other countries, in particular on the occupied lands (Soeseman 2002).

The German national idea happened to play an important role in the public opinion of the post-war Germany. As the German researcher Viperrman concluded that nationalism represented such movement for the revival of the German national ideas and was widely used by A. Hitler in his speeches before the workers and other population of Nazi Germany. This type of the propaganda made post-war Germany rouse the masses in any case (Wipperman 1989).

Analysis of papers of native and foreign scholars on the issue of the formation of the German information space in the zone of military administration and in areas controlled Rejhskomisarìatu "Ukraine" in the years of the World War II allow to conclude that there is evidence that scientists use different methodological and informational and ideological principles and approaches in the study of this problem. Despite this fact the theme remains scantily explored.

Historiographical overview indicates that the problem of information confrontation between Germany and the Soviet Union needs deep study and definition of certain important issues that require an objective judgement. It is desirable that the German information space and the rapid dissemination of Nazi propaganda among the population of the occupied regions of Ukraine should be studied covering complex political, military, social, and psychological situation that existed in the years of war.

With the beginning of the German occupation there was began a massive information attack on the consciousness of the population of Ukraine. Local residents expressed a different attitude towards the occupation of the Administration. So a small part of the population was to collaborate with German soldiers with ideological motives. It believed in changes for the better. Other part of inhabitants took waiting position. Some of the inhabitants realizing the true plans of the Nazis tried to resist and support the Soviet partisans and underground fighters. There was also a certain part of the population who represented participants of the different directions of 
Ukrainian Self-Government movement. The following categories of population were pressed by the influence of the German information policy and propaganda. It had the civilian population to be in a state of discouragement, loss, doom and terror. In our opinion such information and advocacy policy of the German occupation administration put questions before a large part of the population: who was a really an enemy? With whom and against whom to fight, and fight at all? An important factor of propaganda turned out to be Ukrainian national movements. They, on the one hand, offered locals an alternative to fight against all the creation of their own State and made situation be more difficult for the peasantry.

Considering the individual works of foreign historians, it should be noted that the information policy of the Nazi Germany and its attempt to create in Europe and on the occupied territories a special information space happened to pay attention of historians and Essayists from Russia, Great Britain, the United States and Germany. Contemporary vision and understanding of the information policy, information space helps scientists to study comprehensively the events of World War II and the German-Soviet war. Information confrontation between the USSR and Nazi Germany increasingly attracts the attention of modern scholars and its study helps to cover a full picture of the events of 1939-1945. However it should be noted that historians of Germany, the United States and Great Britain dealt with Nazi propaganda on the territory of the Third Reich and its influence on the Red Army and the population of the occupied territories of the USSR mainly in the context of the Eastern policy of the Nazi Germany.

90-ies of the twentieth century and the beginning of the 21 st century were marked with the emergence of numerous works of Russian historians who studied ideological and political activities of the Communist Party of the Soviet Union and the military leadership of the country during World War II. In the context of this theme there were studied the periodical printed publications, information Bureau, oral advocacy, propaganda among the personnel of the Red Army and the population of the occupied territories in Ukraine and Belarus.

That's no doubt that the work of A. Sirokorad is considered to be original one. The author investigates the activities of Central printed periodicals and their impact on the population of the rear and occupied areas of the USSR (Широкорад 2002).

Basic principles of Soviet propaganda were also investigated by N. Kamenieva who had covered the activities of Party propaganda organs of the USSR, and the forms and methods of work of the female part of the population including the deliberations of the anti-Fascist Committee of Soviet women (Каменева 2004). 
A great attention to the leadership of the Soviet Union during the war was focused on the creation of the image of the enemy-fascist. This idea became the key of the soviet propaganda in the activities of the party and the military authorities. This aspect was dealt with the work of the Russian historian A. Fateev. He noted that Soviet propaganda was not less efficient than German because there were modern techniques and technologies of ideological influence on the population and the personnel working as of its own and enemy armies (Фатеева 1999).

Some individual Russian historians present material about the system of ideological impact that there was constructed in the USS, long before the start of the war. The work of M. Mazuricky is devoted to the changes according to the ideologically-advocacy having spread its influence on social consciousness and the consciousness of each individual in particular. $\mathrm{He}$ managed to reveal the directions of professional activities of librarians in the years of war (Мазурицкий 1995).

In his work "Soviet Propaganda in the Great Patriotic War" Russian historian A. Gorlov gave the historical-political analysis of Institute of the Soviet Communist Party propaganda of the period of the Great Patriotic war. The author managed to identify the basic structure and resource potential of propaganda as well as to detect and identify the main stages of the outreach work among personnel of the Red Army and population in the rear during the war. While analyzing a significant number of documents the historian had determined the degree of effectiveness of the Soviet military propaganda expressed in the form of their manifestation (Горлов 2009).

Having confirmed the thesis that the Soviet information and ideological influence was no less powerful than the Nazi. the work of I. Livsina and I. Orlova ("Soviet Propaganda in the Great Patriotic War, and Communication Conviction") introduced a large number of archival documents and materials. The authors covered the structure and mechanisms of functioning of the Soviet propagandist's apparatus during the War of 1941-1945 between Germany and the U.S.S.R. For the first time in the Russian historiography there were comprehensively investigated and published promotional materials of the Communist Party and State. They revealed various forms, methods and techniques of influence on the soldiers at the front and the civilian population in the rear and on the occupied territory. New found documents are known to denote the effects of Soviet propaganda on the rear and the occupied territories, as well as the depth and effectiveness of propaganda's impact on mass consciousness wholly (Советская пропаганда в годы Великой Отечественной войны: «коммуникация убеждения» и мобилизационные механизмы 2007). 
It should be noted that such powerful information attack carried out by Nazi Germany made the USSR resist on it by not less powerful informational and ideological weapon. There was the Soviet leadership. The informationideological machine that had a big impact on the vast majority of the population of the State had been functioning successfully for 24 years.

Recently the Internet network has become a necessary source of information and means to study the problems of military history of the World War II. There are being created the sites that dedicated to the activities of the Nazi administration on the occupied territories of Ukraine, and the activity of the Wehrmacht and military units formed with representatives of national minorities living on the territory of Ukraine "Rejhskomisarìatu" and the military administration. These sites are completed by archival documents and photo albums (Допрос подсудимого Шпеера 1946). Internet gives opportunity to get an information about a foreign historiography. Computer technologies promote the use of new methodological and technological methods to study the sources, and to model the social processes, to do an operational systematization of all documents and materials.

The Internet seemed to expand the historical source's base devoting to the study of the information policy of the Nazi Germany in the occupied territories of Ukraine. The information policy of the Nazi Germany and the Nazis are being discussed on the basis of the wide use of directories of archival materials, documents, Ukrainian and Russian archives.

\section{REFERENCES}

1. Общественно-политическая жизнь трудящихся Украины в годы Великой Отечественной войны 1988, за редакцией Коваля М.В. Киев : Наук. думка.

2. Коваль М.В. 1999. Україна в Другій світовій і Великій Вітчизняній війнах (1939-1945рр.) Киев : Видавничий дім «Альтернативи».

3. Ивлев И.А. 1988. Оружие контрпропаганды. Советская пропаганда среди населения оккупированной территории СССР. Москва : Мысль.

4. Волкогонов Д.А. 1983. Психологическая война: Подрывные действия империализма в области общественного сознания. Москва : Воениздат.

5. Орлов Ю.Я. 1985. Крах немецко-фашистской пропаганды в период войны против СССР. Москва: Московский государственный университет.

6. Григорович Д. Денисенко П., Немятий В. 1976. Комунистическое подполье на Украине в годы Великой Отечественной войны. Киев : Политиздат Украины. 
7. Волошин Ю. 1997. Українська православна церква в роки нацистської окупації (1941-1944рр.). Полтава: Полтавський державний педагогічний ін-т ім. В.Г. Короленка.

8. Лисенко О.С. 1998. Церковне життя в Україні. 1943-1946 pp. Київ : Ін-т історії НАН України.

9. Лисенко О.С. К., 2002. Ідеологічні аспекти початкового періоду війни: реалії та їх відлуння. Сторінки воєнної історії України: збірник наукових статей. Ін-т історії України НАН України. Вип. 6.

10. Потильчак О.В. 1996. Система примусової праці цивільного населення України в роки німецької окупації (1941-1944). Київ : Молода нація. № 4.

11. Боляновський А. 2000. Дивізія «Галичина». Історія. Львів : Львівський національний університет ім. І. Франка.

12. Сергійчук В. 2005. Український здвиг: Волинь. 1941-1955. Київ : Українська Видавнича Спілка.

13. Гайдабура В.М. 1998. Театр, захований в архівах: Сценічне мистецтво в Україні періоду німецько-фашистської окупації (1941-1944). Київ : Мистецтво.

14. Скоробагатов А.В. 2004. Харків у часи німецької окупації (1941-1943). Харків: Прапор.

15. Гальчак С.Д. 2004. «Східні робітники» 3 Поділля у Третьому рейху: Документи, нацистська каторга, опір поневолювачам. Вінниця: Книга-Вега.

16. Тарнавський I.C. 2005. Відродження на Донеччині німецькофашистської окупаційної політики у сфері освіти (1941-1943рр.). Наук. ж-л: «Історичні і політологічні дослідження». Донецький національний університет. Вип. № 1.

17. Ніколаєць Ю.А. 1999. Становище та настрої населення України на початку німецько-фашистської окупації: (червень 1941 - липень 1942 рр.). Вінниця: Тезис.

18. Черняков Б. 2006. Окупаційна преса Рейхскомісаріату Україна: розбудова і функціонування (1941-1943рр.). Збірка наукових статей. Київ : Ін-ту політичних і етнонаціональних досліджень ім. І.Ф. Кураса НАН України.

19. Шайкан В.О. 2005. Колабораціонізм на території рейскомісаріату «Україна» і військової зони в роки Другої світової війни. Кривий Ріг: Мінерал.

20. Лисенко О.Є. 2007. Соціальні аспекти окупації України: методологія проблеми. Сторінки воєнної історії України: збірник наукових статей. Київ : Ін-т історії України НАН України. Вип. 11. 
21.Гриневич В.А. 2005. Сталінська національна політика щодо національних меншин у роки Другої світової війни 1939-1945 рр. : збірка статей. «Друга світова війна і доля народів України». Київ : Сфера.

22. Михайлюк М. 2005. Нацистська кінопропаганда в окупованій Україні. Український історичний збірник. Київ : Ін-т історії України НАН України. Вип. 8.

23. Титаренко Д.М. 2005. Звіти батальйону пропаганди U як джерело 3 питання про вплив нацистської пропаганди на населення окупованої України. Збірка статей. Друга світова війна і доля народів України. Київ : Сфера.

24. Титаренко Д.М. 2010. «Німецька пропаганда в Україні мусить здійснюватися": цілі нацистської пропаганди в Україні у світлі німецьких документів. Гілея. Історичні науки. Філософські науки. Політичні науки: наук. вісник. Київ: Видавництво Національного педагогічного університету ім. М.П. Драгоманова. Вип. 36.

25. Гинзбург Л. 1990. Потусторонние встречи. Москва : Новости.

26. Черная Л.Б. 1992. Коричневые диктаторы: Гитлер, Геринг, Гиммлер, Геббельс, Борман, Риббентроп. Москва : Издательство "Республика".

27. Безыменский Л.А. 2003. Третий фронт. Секретная дипломатия Второй мировой войны. Особый архив. Москва : Вече.

28. Галкин А.А. 1967. Германский фашизм. Москва : Наука.

29. Hadamowsky E. 1933. Propaganda und nationale Macht. Die Organisation der oeffentlichen Meinung fuer die nationale Politik. Oldenburg, I.O. : G. Stalling

30. Armstrong J.A. 1964. Soviet Partisans in World War II. J. Madison: The University of Wisconsin Press.

31. Мюллер Н. 1974. Вермахт и оккупация (1941-1944): Под редакцией А. Юденкова. Москва : Воениздат.

32. Longerich P. 1987. Propagandisten im Krieg : die Presseabteilung des Auswärtigen Amtes unter Ribbentrop. Munich, Germany : R. Oldenbourg Verlag München.

33. Лонгерих, Петер. Генрих Гиммлер. 2008. Биография. Мюнхен: Сидлер.

34. Koehl R. L. 1957. RKFDV: German resettlement and population policy 1939-1945. Cambridge, Harvard University Press, 1957.

35. Buchbender O., Schuh H. 1974. Heil Beil: Flugblattpropaganda im 2. Weltkrieg. Dokumentation und Analyse. Reihe: Militarpolitische Schriffenreihe. Band 10. Видавець: Seewald Verlag, Штутгарт. 
36. Ферстерч Г. Гельмерт, Г. Отто, Г. Шниттер. 1966. Прусскогерманский генеральный штаб 1640-1965. К его политической роли в истории : перевод с немецкого Рудого Г. Москва : Мысль.

37. Balfour Michael. 1979. Propaganda in War 1939-1945. Organisations, Policies and Publics in Britain and Germany. London, Boston and Henley.

38. Jowett G.S. O’Donell V. 1992. Propaganda and Persuasion. Newbury Park etc. Stuttgart

39. Кершоу Я. Гитлер. 1997. Ростов на Дону: Феникс.

40. Soeseman B. 2002. Propaganda und Oeffentlichkeit in der "Volksgemeinschaft". Nationalsozialismus und die deutsche Geschichte: Einfuerung und Ueberblick. Deutsche Verlags-Anstalt : Stuttgart-München.

41. Wipperman W. 1989. Der кonsequente Wahn: Ideologie und Politik Adolf Hitlers / Wolfgang Wippermann; mit einem Essay von Saul Friedländer. - Gütersloh ; München: Bertelsmann Lexikon Verlag.

42. Широкорад И.И. 2002. Центральная периодическая печать СССР в годы Великой Отечественной войны (1941-1945 гг.). Москва : Московский гуманитарный университет печати.

43. Каменева Г.Н. 2004. Женщины Северного Кавказа в годы Великой Отечественной войны (1941-1945 гг.). Ставрополь: Ставропольский государственный университет.

44. Фатеев А.В. 1999. Образ врага в советской пропаганде. 1945-1954 гг. Москва : Институт росийской истории.

45. Мазурицкий А.М. 1995. Очерки истории библиотечного дела периода Великой Отечественной войны. 1941-1945 гг. Москва : Московский государственный институт культуры.

46. Горлов А.С. 2009. Советская пропаганда в годы Великой Отечественной войны: институциональные и организационные аспекты. Москва : Росийский государственный университет туризма и сервиса.

47. Советская пропаганда в годы Великой Отечественной войны: «коммуникация убеждения» и мобилизационные механизмы 2007. Уложили А.Я. Лившин, И.Б. Орлов. Москва : РОССПЭН.

48. Допрос подсудимого Шпеера. Из стенограммы заседания Международного Военного Трибунала от 21 июня 1946 г. Режим доступа: Доступ марта 20, 2014. http:/historic.ru/books/item/f00/s00/ z0000021/st018.shtml. 


\section{SECTION 2.1. \\ UKRAINE IN THE CONCEPT OF MILITARY-POLITICAL STRATEGY OF NAZI GERMANY}

Throughout the 20th century Ukraine and its territory were under close attention of the European countries and the managements, at first the Russian Empire, after the USSR, and today - the Russian Federation. "The Ukrainian question" became one of the important aspects in geopolitical and militarypolitical plans of these states. In particular, in the thirties of the20-th century the Ukrainian lands happened to became a subject of military-political plans of Nazi Germany ("The Third Reich"). The political leadership of the "Third Reich" had concrete plans for the territory of Ukraine as "living floor space" for the German colonists and resource base in aggressive plans in the east of Europe.

The military-political strategy of Nazi Germany expressed main objectives and tasks of the National Socialist Workers' Party of Germany (further NSDAP). The German national socialists under the motto of "expansion of living floor space for Germans" actually sought to establish dominance in eastern countries and to reach the aggressive ambitions.

The political concept developed by the political leadership of the Third Reich represented a complex of views of implementation of policy by the state, public organizations, certain citizens. In Germany conceptual framework of state policy actually became the doctrine reflected also for Party's political struggle and turned into ideology.

According to the political concept in Germany it was developed militarypolitical strategy which represented set of political actions in the field of safety and defense, to the state system of the military-political ideas, beliefs and practical measures, defined the purposes and the general orientation of political struggle, a form, methods and ways of its maintaining, reflected military aspects of the highest national interests and safety of the state.

Military-political strategy of Hitler's Germany of the 30th years consisted in the development and realization of a complex of the most important military-political tasks, Formation of the sequence of their performance, definition of the main directions and purposes of military policy at different stages of formation of the "Third Reich" and warfare, definition of the corresponding arrangement of military-political forces and development of the plan of their use for the longest period. 
The main questions and the general orientation of military-political strategy of fascist Germany were defined on a national level. It systemically and purposefully considered features of a social-political system and the final purpose of the state, the actual level of its military power, economic, political, diplomatic abilities in favor of the solution of important military-political tasks by providing a whole country and regional security of the state. The military-political strategy of fascist Germany took the defining place in relation onto tactics of military-political actions.

Hitler's military-political strategy became an important setup of the military policy of Germany. It expressed socio-political, strategic and military and technical bases of the military doctrine, character and problems of military strategy of the state.

According to the concept and the strategy of Nazi Germany the Hitler's administration developed the principles of military policy:

- Compliance to long-term political goals and a military-political situation in Germany, Europe and the world in the 20-30th years of the 20th century;

- Use political, economic, diplomatic and military measures for the solution of constant military-political tasks;

- Use of social and economic and strategic advantages of the country;

- Identification and use of weak and weak spots in the military system of the state opponents And also contradictions in the system of their relations;

- The solution of military-political and strategic tasks, with the minimum moral and political and material inputs;

- The attraction of the party of the maximum number of allies and ensuring unity of joint efforts;

Consecutive weakening of potential opponents.

With the coming to the leadership of the Nazis in Germany gaining new "living floor space" for Germans as people of the highest race became a main goal of foreign policy as A. Hitler proclaimed in the work "Mayne Kampf". He noted: “... For Germany the only possibility of carrying out healthy territorial policy consists only in gaining new lands in Europe... It is necessary to understand clearly that these objectives can be achieved only by war". Today we speak to Noyesli about new lands in Europe, first of all, we have to mean only Russia and border states subject to it" (Hitler 1943, 147, 152-155, 741-742, 766-767). The Nazi Fuhrer understood the western republics of the USSR, including Ukraine as the last. This thesis demonstrates that Hitler well understood that Germany had an uncountable raw richness of the Urals, the woods of Siberia, fertile plains of Ukraine - it would become a powerful raw basis of the Third Reich in the adoption of the domination over Europe, and eventually and over the world. 
The leading role in the development of the foreign policy concept of the German fascism belonged to the monopolistic bourgeoisie of Germany to increase the capitals and to expand economic influence. Monopolistic circles paid much attention to east expansion in future. An example of it is the letter which was sent to Hitler in October, 1933 on behalf of the board of Deutsche Bank. In it was noted that the German people have an opportunity to receive territory in the east. According to bankers when a part of the German people finds the homeland in the east, then it will be possible to think also of occupation of other territories (Auf antisowjetischem Kriegskurs. Studien zur militarischen Vorbereitung des deutschen Imperialismus auf die Aggression gegen die UdSSR (1933-1941) 1970, 64).

The German bourgeoisie and financial oligarchs sought for expansion of the field of the activity and east territories, according to them, were still a little more developed, not mastered. Territories of the USSR, in particular the Ukrainian SSR, they considered a perennial spring of cheap raw materials. So in November, 1938 large industrialists, the radical revisionists and aggressive anti-Semite entering in a political fraction led by A. Rekhberg sent to the chief of imperial office the appeal in which they noted: 2The space of Russia is object of expansion of Germany..., it has inexhaustible potential riches in the field of agricultural industry and raw material resources which are not developed yet. If we want that expansion provided to Germany transformations to the empire from sufficient for its needs agrarian and a source of raw materials, then it will be necessary to occupy all Russian territories to the Urals including areas where huge ore riches" (Айххольц 2002, 62-89).

About plans of the German financial oligarchy and Hitlerite management it is possible to judge also on record about a meeting of members of the economic headquarters "East" and methods of its realization which took place on May 2, 1941.Ttheir purpose was robbery of the Soviet areas which were planned to be occupied. At a meeting it was stated that it would be possible to continue war only if the armed forces of Germany on the third year of war were provided with food from Russia. At the same time most of the participants of the meeting recognized that downloading from the country of natural resources necessary for Germany, would lead to the fact that tens of millions of people would be doomed to hunger. Despite it the most important crops which will go as food for providing the German troops were defined.

In this context it was important to restore the industrial enterprises. It was decided to restore only those which make scarce products. Among them: Plants on construction of vehicles; The plants on construction of the constructions used in various industries of delivery (steel constructions); 
Textile Enterprises; The military enterprises - only such which are not enough in Germany. Also, it was offered to organize a large number of repair shops for military needs (Дашичев 2005, 23-24.).

In spite of the fact that on August 23, 1939 between Hitlerite Germany and the USSR the Non-aggression pact was signed and the confidential additional protocol is signed, Germany continued to make plans of a campaign in the East. Germany allocated the special place in the aggressive plans to the Soviet Union, including Ukraine. In its territory Germany intended to create the German military settlement which population had to become "the dominating race". In the context of this policy the program of creation of country farms from ethnic Germans was developed.

The Hitlerite political leadership and management systematically made plans for occupation of east territories. On July 21, 1940, for the first time reporting military command about the intention, to attack as soon as possible the USSR, A. Hitler, by the way, declared the next political goals of Germany, in particular plans concerning the fate of the Ukrainian statehood, Federation of the Baltic states and Belarus. Certain Hitlerite leaders expressed opinion on as soon as possible to occupy east territories, so vital Germany for the solution of the more global geopolitical problem. Among them there are I. Goebbels, G. Himmler and G. Goering (Гальдер 1969, 60). In the late thirties these thoughts were often discussed by the famous German politicians who considered that for the weakening of Russia it was necessary to tear off from it Ukraine, which, maybe, would become the independent state focused on Germany stated and would always serve as a counterbalance of Russia.

This discrepancy in plans of certain political figures reached the greatest intensity at the beginning of March, 1941 when preparation of the German attack on the USSR was already finally resolved the issue. The Supreme command developed then "The leading installations on the special questions connected with directive No. 21 (the plan Barbarossa)". As a special question future policy in the occupied Soviet territory was allocated.

In this regard on December 18, 1941 the chief of staff of military operation presented to the leadership of the military forces of Germany the advanced draft of the plan taking into account all remarks of Hitler and the document Guidelines with special questions as the addition to directive No. 21 - "The Plan Barbarossa". It is necessary to notice that in the document it is accurately noted that the campaign, which is planned is something bigger, than just military fight, is the conflict of two outlooks. In the previous version of the project, it was necessary to consider scaling of the territory of the USSR, and in this regard the Soviet country needs to be divided into a number of the certain states with own governments which would be ready to enclose peace 
treaties with Germany and further to cooperate with it. Also the fact that it is necessary to think over and develop the general principles of behavior and cooperation with these states for the creation of such governments was noted. According to the leadership of Hitlerite Germany, the old bourgeois and aristocratic, Jewish and Bolshevist intellectuals will interfere with the cooperation process therefore it is offered to destroy it (Розанов 1970, 60).

One of the important questions, according to Hitler, was not to allow fomation of the nation state because as a result it would become the enemy of Germany again. The formation of the national states was not in Hitler's plans therefore to directive No. 21 changes were made. It is offered to create not the states, but geographical units, in particular to one of them had to enter Ukraine and the Crimea with the center in Kiev (Розанов 1970, 60).

Kiev was defined by the center because the long historical period it had been the considerable cultural and political center, since Kievan Rus', later the constant rival of Moscow. The main political line in this region was to encouragement of aspirations Ukrainian for national independence, to potential creations of own statehood or reunification of Ukraine with the Don region and the Caucasus. Such an association, according to the Hitler's leadership it would be the Black Sea Union, which would resist to Moscow would make it continuous threat, protecting the german living floor space from the East. At the same time this area would form a powerful source of raw materials of the Velikogermansky empire.

Creation of a political counterbalance of Velikorossiya and conditions was an important aspect of this concept. It would lead to its easing. According to the Hitler's leadership plans, it was for this purpose it's necessary to attach the suburban areas which were earlier a part of the Russian space: part of the Kursk and Voronezh regions.

Generally in the directive it is offered to create the action plan which would provide formations of the central body for coordination of actions in the territory of the USSR. Among tasks we see the development of obligatory political instructions for separate administrative units taking into account a concrete situation and a goal; ensuring important military deliveries from all occupied areas in favor of the empire; development and solution of the general questions, essentially important for all areas, such as financing, transport, production of oil, coal and food products.

The directive also provided accurate differentiation on the competences of local governing bodies of certain administrative districts which represent the closed national or economic and political units, for the solution of local and other tasks («Совершенно секретно. Только для командования» 1967, 149-153). 
According to the formulated foreign policy concept of the "Third Reich" in the "Plan Barbarossa" the plan of use of future territory occupied by the German army in the east was developed. It is called as "Oldenburg". It was developed and approved in March, 1941Ito provide the plane right after the end of military operations by holding grandiose economic actions for use of resources of the occupied territory of the Soviet Union. It was created the economic headquarters, which was completely separated from the General Staff. The plan supposed to transport in the Reich the most valuable industrial equipment, and all the rest, it iwsa not required for the German industry - to destroy. The territory of the USSR was planned to be decentralized economy and to make a raw-material producing appendage of Germany (Загорулько 1980, 17).

The establishment of complete domination in Europe could not be realized without the destruction of the USSR. The Hitler's leadership saw the key to success in implementation of the major political, economic and strategic tasks. But the leadership of Wehrmacht understood that the western countries wiould not prevent Germany to carry out aggression in the East until it did not develop into real danger to them. The Hitler's leadership tried to avoid dragging-out war on two fronts. Therefore the first steps which were carried out by fascist Germany were drawing the first blow of France and a conclusion of war on England. Attack on the Soviet Union had to take place only after the solution of tasks in the West. This political concept was also reflected in the known work of Adolf Hitler "Mein Kampf" and became fundamental in the Nazi military doctrine. At a meeting of the governmemt of Wehrmacht on November 23, 1939 Hitler noted: "Russia does not constitute danger now. Today it is weakened owing to many internal processes. Besides, we have a contract with Russia. But contracts are observed until they are expedient... We can oppose Russia only when we are released in the West" (Дашичев 1967, 76-77).

In this regard the Military doctrine of fascist Germany was developed on the basis of military knowledge of the famous German theorists A. Shliffena, E. Lyudendorf, F. Berngardi, X. Ritter, R. Sudan and many others. It incorporated experience and a new approach in the military theory and practice of construction of the armed forces of England, France, Italy, Japan, the USA (Дашичев 1967, 76-77).

In developing the military doctrine leadership of the "Third Reich" paid much attention to information and propaganda activity of one and all ministries of the "Third Reich" both in Germany, and beyond its limits (Фрунзе 1951, 148). 
In this way the basic principles of the general strategic concept of Hitler's command consisted in weakening and dividing the main opponents of fascist Germany to avoid simultaneous war against England, France and the Soviet Union and not to allow creation of the anti-German coalition; to embody the idea about drawing the first blow in the West for the purpose of defeat of France and a conclusion from war of England, and to further begin military operations against the countries of the East. The implementation of the plan in such sequence would have to provide to Hitler's Germany total domination in Europe and further expansion of its world expansion. Also calculations were made on the fact that Italy would undermine strategic positions of Great Britain in the basin of the Mediterranean Sea, and Japan will distract the main forces of England, and further and the USA, from Southeast Asia and also was blocked by the Soviet Union on the Far East borders (Weltgeschichte der Gegenwart in Dokumenten. Geschichte des Zweiten Weltkrieges 1954, 38).

This policy of fascist Germany brought the results. Because the European states did not believe in Hitler's intentions, his government quickly enough managed to decide destiny of the countries of Central, Southeast and Northern Europe and at their expense considerably to improve a strategic and economic situation of Germany, promoted further warfare.

Along with conducting military operations in Europe, the German leaders embodied the tasks set for the German economy and armed forces till 1939. to be prepared for global war. In the memorandum of economic preparation for war created in August, 1936 it was noted: "War has demanded so large amount of raw materials in world history never before was a case who really managed to create stocks for a long time...". Here Hitler sets two main objectives for the German economy: “... I set the following tasks: 1) in four years we have to have an efficient army; 2) in four years the economy of Germany has to be ready to war" (Дашичев 1967, 76-77).

Since the mid 1940s the colonial program of Nazi Germany seemed to be developed by Hitler's leadershipt. In the last version of the program the object was set to create the German colonial empire in Africa including all German colonies. About colonial ambitions and plans it is possible to judge on Claudius, Korsvant, Ritter's memorandums. All of them came down to one that after the victory over France and England they planned to take freely economic positions in the Middle East (Schmokel 1964, 124).

How seriously German leaders prepared for colonial conquests you can judge by the fact that in 1940 in Germany the Colonial Office led by Von Jepp was secretly created and began to form colonial troops which number was planned to be brought to 100 thousand People (Дашичев 1967, 30). Till 1943. The Hitler's government did not lose hope for the creation of the German 
empire and accession of new attached territories in the east and the Southeast. This thought confirmed by Trevor-Ropera's work "Hitler's Table Talk 1941-1944" where the author noted that the fascist German leaders expected to achieve these objectives after defeat of the Soviet Army. He reminds that in one of conversations in a narrow circle of adherents Hitler said: "That day when we establish our firm order in Europe, we will be able to turn the look into Africa. And who knows, maybe, one day we will be able to undertake achievements and other purposes" (Hitler's Table Talk 1941-1944, 1953, 497).

Development of the concept of Nazi policy in eastern occupied territories was the following step in the colonial program of the "Third Reich".

The policy which was pursued by the Hitler'sleadership in the occupied territories was a component of aggressive plans of Germany in World War II. To expand "the living floor space" of Germany it was planned first of all at the expense of territories of the Soviet Union and other Slavic countries. Already on the eve of war detailed plans about the device of Eastern Europe are developed. The first version of the plan "Ost" was developed by the 1941 "Head Department Imperial Safety" and was presented on May 28, 1942. The employee of Management of the headquarters of the imperial commissioner for consolidation of the German people, the ober-Fuhrer the SS Meyer-Hetlingy under the name "Master Plan of "Ost", Basis Legal, Economic and Territorial Structure of the East" (Дашичев 2005, 13).

Unfortunately the full text of this plan is not found. At the trial, in Nurernberg the only evidence of the plan was the comments, remarks and offers of the Ministry of "East occupied territories" on the master plan of "Ost", according to the user's accusers the chief expert, the employee of the Ministry of "East territories" E. Vettsel after acquaintance with the draft of the plan prepared were on April 27, 1942 the only proof of existence of the plan PCXА (Замечания и предложения “восточного министерства" по генеральному плану "ОСТ" 2009). The main objectives of the Hitler's leadership of Germany are reflected in the plan of "Ost" and directed on:

- Political and military gaining the space taken and in the distant future by "eviction" of indigenous people, including mass destruction and colonization, that is "violent assimilation" (Umvolkung);

- Social and imperialistic interest in strong fixing of own social base by means of "settlements", that is by means of creation of the extensive, depending on the mode, economically strong layers of the German peasants and large landowners and also by means of association of the German city center;

- the expansion of the large capital directed to raw materials operation (oil, ore, metals, cotton and other agricultural raw materials) on huge sales 
markets of the consumer goods, on expansion of investment opportunities and the markets of export of the capital (in particular the military industry - weapon and military equipment) - military construction, airfields, "strong points" and the "German" settlements, country estates, industrial and transport structures of all types) and receiving cheap labor; interest in inexhaustible sources of food for "misters" for the unlimited period (Замечания и предложения "восточного министерства" по генеральному плану “ОСТ” 2009).

The separate main ideas "The Master Plan of "Ost"" are known to be developed and proclaimed during World War I.

In the period of World War II this plan united barbaric racism and antiSemitism and for officially stated purpose of genocide, destruction of the whole races and the peoples. It is clear that this plan proclaimed the policy of the "Holocaust". Including racist intention to destroy tens of millions of Slavs, "The Master Plan of "Ost" was also main experimental space for murder of Jews across the whole Europe and the whole world and had to provide territories for unlimited number of "a ghetto" and extermination camps. Unlike the "Holocaust" "The Master Plan of "Ost"" provided the wide program of robbery and expansion.

The interests of "East territories" were explained by "Bolshevist threat", or the need for expansion of "living floor space" for Germans. One of the participants of "the Nuremberg process" gave evidences that at the beginning of 1941. Himmler explained to twelve heads of groups CC, the extermination of 30000000 Slavs was "the campaign purpose against Russia" (Der Prozeß gegen die Hauptkriegsverbrecher vor dem Internationalen Militärgerichtshof 1947, 356). The same witness confirmed Soviet to the accuser, explaining the main reasons for fight against guerrillas, "that fight against the guerrilla movement was quite an important reason for extermination of the Slavic and Jewish population". By the beginning of East campaign Hilter made the order that the busy areas "as quickly, as it is possible", were calmed "best of all, shooting everyone who will glance slantwise" (Bd. 38. Nürnberg, 1949, 87).

According to L.A. Bezymensky, the Plan "Ost" was developed step by step, at first it was "The Small Plan" ("Kleine Planung"), and then Makro ("Grose Planung"). "The small plan" should be carried out during war. The German government wanted to focus on "The big plan" after the war. The plan provided different percent of germanisation for various subdued Slavic and other people. Those which are not subject a germanisation have to be moved to Western Siberia. Thus, implementation of the plan had to provide realization of the colonial policy of the Reich, and the won territories gained purely German value (Безыменский 1972, 258). 
The plan of "Ost" was thoroughly worked out.It contained tables, schedules, estimates that demonstrated serious intentions of the nazi command.. From the section "General Ideas of the Management" we see that capture and use of east territories, their transformations to full-fledged imperial areas is considered by the management of the Reich as noble of tasks. Also creation of the healthy peasantry was planned to settle of rural regions. For so global carrying out colonizer tasks, it was supposed to separate areas which had to be populated on ethnographic signs, creation of a uniform control system in all colonized regions (Безыменский 1972, 259).

The conceptual principles of policy of the "Third Reich" in relation to the population of "east areas" are brightly reflected in Himmler's note of May 25, 1940 under the name "Some Reasons about the Address with Local Population of East Areas". It was dispatched in all managements of the Hitler's device on places. The document says that: "As for separate nationalities we do not seek for their consolidation and increases, especially for the gradual instilling of national consciousness and national culture in them. For the German population of "east areas" there should not be higher schools. It's enough to have a four grade national school education to be able to count to 500, not to teach reading and ability to undersign, to suggest that the divine precept is in obeying Germans, to be honest, diligent and obedient. Except school of this kind, in "east areas" there should be no schools" (Безыменский 1972, 88-89).

According to the "Master Plan of "Ost" aggressive economic plans concerning the people of the Soviet Union closely intertwined with ideological interests. Hitler's speech at a meeting with generals on May 30, 1941 where he noted that war with the USSR was a collision of two ideologies, ruthless war for the purpose of destruction of the Bolshevism demonstrates to it, it is a war in which, "cruelty - the benefit for the future" (Безыменский 1972, 93).

Several departments of the "Third Reich" were engaged in the development of the plan of "East campaign" and use of east territories at the same time. One of developers of plans on eastern occupied territories A. Rosenberg. Since 1933 he had been the chief of the NSDAP. Within the authority of this body the special center for problems of "east territories" "the Central Political Bureau" was created in April, 1941. On Rosenberg's memoirs, on April 2, 1941 Hitler announced the decision to appoint him the Minister of Affairs of the Occupied East Territories. On the same day A. Rosenberg prepared the memorandum of the purposes and methods of the German occupational policy for territories of the Soviet Union "Armed struggle with the Soviet Russia, - it was said in it, - will lead to the fast 
occupation of the most parts of the territory of the Soviet Union, are important. It is very obvious that military operations from our party will lead to a fast crash of the USSR" (Безыменский 1972, 253).

In the memorandum Rosenberg emphasized that the relation to separate parts of the territory has to be initially directed to the achievement of the set political goals both in management, and in the economic and ideological relation. In the memorandum he drew up plans, according to different parts of the Soviet Union. The kindling of hostility between various nationalities of the USSR for the purpose of implementation of German policy. It became a cornerstone in the offered concept. The Baltics - Estonia, Latvia and Lithuania - had to become area of the German colonization. It was put also forward the plan of creation of the Black Sea union as a part of Ukraine, Don and the Caucasus in order that constantly to keep Moscow under the blow and to provide "German living floor space from the East". Along with it's creation of the state formations subordinated the "Reich" were headed by the German leaders - commissar was offered. In economic sense these states had to turn into an agrarian appendage of future fascist empire (Германский империализм и вторая мировая война 1963, 117).

The Ministry of East Occupied Territories under the leadership of A. Rosenberg developed structure of the occupational device for the Soviet territories. In the annex to the memorandum of April 7, 1941 (No. 2) it is told about the persons appointed to the major positions in administrative facilities in the east. So, to a position of the imperial commissioner of the Baltic countries and Belarus Rosenberg recommended the gauleiter Heinrich Loze, for a position of a reichskommissar of Ukraine - Shikedantsa,. Within 20 years he was busy with the development of "the Russian question". For the management of the Caucasus it was offered Bakke, who is considered to be of the Caucasus's origin. Reichkommissar it was offered to the area Don-Volga D. Klagess, the minister of Braunschweig. In case of occupation of Moscow Rosenberg planned for a position of a reichskommissar of the gauleiter of East Prussia Erich Koch (Германский империализм и вторая мировая война 1963, 118).

Proceeding from political reasons, on April 20, 1941 A. Rosenberg was appointed the representative of the "East European regions". To the chief of staff of OKV W. Keitel, it was sent the order on Rosenberg's appointment and it is recommended to render it any help (Нюрнбергский процесс. Сборник материалов. 1955, 548-549). Soon W. Keitel issued the order on a business trip of the corresponding persons in department on the development of occupational policy in the East. All negotiations on questions of "East space" were held further by public officials of OKV (Нюрнбергский процесс. Сборник материалов. 1955, 551). 
Establishing cooperation with the Ministry of National Education and promotion of Germany was the following step in the activity of the Ministry of East Occupied Territories. A number of negotiations as a result of which the agreement of rather a historical and political understanding of "East problem" was reached. All political and other articles, texts, speeches and addresses were carried out had to be carried out in Rosenberg's department. The content of propaganda work had to be coordinated with the instructions of the Ministry of National Education and Promotion.

As Rosenberg sought to use the population of the occupied territories of the USSR against Soviet leadership. Much attention had to be paid to a question of preparation of propaganda activity among locals. Responsibilities of the Ministry of National Education and Promotion and other departments were accepted by Rosenberg and "are instructed concerning positions which they will have to occupy with a request to coordinate terminology of the press, whenever possible avoiding any publicity".

Expecting a close victory over the USSR, at a meeting of the Nazi leadershipon July 16, 1941 on "a new order" in occupied territories Hitler said: The creation of military states to the west of the Urals never has become on the agenda... All followers of the Fuhrer have to know: "the empire only then will be in safety when to the west of the Urals there is no foreign army. Protection of this space against any possible dangers undertakes Germany..." ("Преступные цели - преступные средства" Документы об оккупационной политике фашистской Германии на территории СССР. 1968, 50-51].

At this meeting the question of punishment over peace the population was also considered, resisted the occupational mode. Most of the present heads of the "Third Reich" came to a conclusion that most likely this problem could be solved only by execution of participants of resistance. In the performance W..Keitel noted that it was necessary to make local population responsible for the acts because it was impossible to put protection on each shard, at each station. "Locals have to know that they will be shot everyone who shows inaction, and they will be made responsible for any offense. At the same meeting it was approved imperial commissioners for Ukraine and other occupied territories ("Преступные цели - преступные средства" Документы об оккупационной политике фашистской Германии на территории СССР 1968, 53-54].

Thus the policy of the authorities of occupied territories of Ukraine, the Baltics and the Caucasus, according to A. Rosenberg, had to be more loyal, than to the Russian population. Thanks to it the occupying command would find support in the fight against the Soviet Union. But Hitler's plans were not 
"flirting" with the population of occupied territories, fast colonization of the occupied "east areas" as it was planned. According to the leading Nazi heads G. Goering, G. Himmler and M. Borman, Germany could carry out the colonization of "east space" absolutely independently without assistance of local nationalists.

After the invasion of fascist Germany on the territory of the USSR Hitler and his government did not hide the present plans on east the people inhabiting the Soviet Union anymore. The main goal, among these plans was to deprive east people "any form of the state organization and compliance with it to hold them at perhaps a lower level of culture". Existence of east people, according to him, came true the fact that they can be useful only in an economic sense (Hitler's Table Talk 1941-1944. Trevor-Roper. 1953. 424).

Real plans of Nazi Germany are opened also by the letter of Martin Borman This letter was directed at the request of Hitler to Rosenberg. In the letter Borman stated Hitler's wish about the principles which need to be observed, according to him, in the occupied east territories.

In the letter the opinion that the leadership of the Reich is not interested to increase the population of these territories, therefore it offers the whole program of reduction of birth rates among Slavs is accurately expressed. Also the fact that it is not necessary to give to local population the higher education at all is noted: "If we make this mistake, we will generate in the future resistance against us. Therefore, according to the Fuhrer, it is quite enough to train local population, in particular so-called Ukrainian, only in reading and the letter" (Дашичев 2005, 39).

Hitler suggested that the leadership should pay a special attention to the events held by the occupying authorities. They should not contribute to the development in a local population of pride and advantage. It is necessary to take care of that Germans contacted to local population a little, did not live in the Ukrainian cities. For them the new cities and settlements supposed to be built, strictly isolated from the Russian (Ukrainian) population. Therefore houses should have been designed not like constructed for Germans in comparison with Russian (Ukrainian). Design. Mud huts, straw roofs and other for Germans were excluded.

In total in the radical territory of the empire a considerable part of "living floor space" supposed be regulated by the law. But it was offered to be avoided in the occupied east areas. According to Hitler's conception, for the local population, it was not necessary to issue many laws. "The German administration has to be small here. Regional the commissioner should work with local heads. It is not necessary to create a uniform Ukrainian board at the 
level of a general commissariat or even the Reichskommissariat" (Дашичев 1967, 122-123).

The Nazi leadership planned to minimize the population of Poland, Ukraine and Belarus and on their lands to lodge in 10 million. German colonists. Those Poles, Ukrainians and Belarusians who had to survive to be used as free labor man power for the German owners. The occupying authorities had the instruction to keep the population in obedience by extreme cruelty, to constantly apply mass executions and other types of destruction (Нюрнбергский процесс: Сборник материалов 1988, 89).

From the beginning of occupation in the occupied territories the accurate control system to A. Rosenberg was created commissariats submitted four imperial: Ostlandian, Ukrainian, Moscow and Caucasian. Each of them was divided into general commissariats. According to Reykhskomissariat Ukraine was divided into Volynsk and Podolsk, Nikolaev, Zhytomyr, Kiev, the Dnipropetrovsk and Taurian general commissariats. Regional commissariats were the lowest link on the German occupation administration. In the occupied Soviet territory it was planned to create 1050 such commissariats. Since their completion 144 officers of the assault groups (SA), 711 officials of the Ministry of Internal Affairs and the Labor Front organization (Дашичев 2005, 10).

Ostlandian Ukraine in the administrative-territorial relation also consisted of general districts, local areas ("gebit"), districts, areas, counties, ballasts which headed general, "debit" and regional commissioners. The western areas of the Soviet Union that were occupied had no uniform civil authorities and the unified power bodiest. In the cities justices, in rural districts commandant's office was created. Actually, all local authorities, in areas, belonged to the corresponding military commandants. From among the local population, local administration foremen or burgomasters, in villages - heads intended. The Soviet system of the administrative device was destroyed, and public organizations were banned (Дашичев 2005, 11).

According to the principles of implementation of rural and city colonization occupied territories of the Soviet Union were divided into two groups: also socalled borders are included in the Reich. Actions for mass German colonization were supposed to be carried out at the expense of the population of occupied territories. There were fulfilled actions on "Germanisation" of the population of the border Regions of Crimea and the Kherson region. By forcing the local population on colonized territories it was planned to carry out road, industrial, city and rural housing construction for the account, besides local population. All plans of colonization were provided to be carried out within 25 years. It was also planned to spend considerable funds for development of agricultural industry, which has become a raw appendage to the German empire 
(Немецко-фашистский оккупационный режим (1941-1944 гг.). 1965, 139). In case of implementation of the plan of "Ost" destruction large the material resources in the east and the pursued policy of a full agrarization of the occupied territories will be destroyed to occur.

The Nazi government, pursuing occupational policies in the East, created conditions, worsened the situation of the local population. So people perished from hunger, it even facilitated, according to Himmler, colonization process. During the meeting of the top management of SS in Vezelsburzi he openly said that one of the problems of East campaign was the destruction of 30 million. Slavs (Германская экспансия в Центральной и Восточной Европе 1965, 273).

The information and ideological concept which had to become the conductor of interests of Hitler's Germany not only in Western and Central Europe but also in the East figured prominently.

To keep in obedience such the large territory, avoiding resistance from local population, it was also necessary to adjust on places police functions. In this regard on July 17, 1941 Hitler signed the order for police protection of the occupied east areas. The leadership in protection was assigned to the Reichsfuhrer-SS and the chief of police of Germany G. Himmler, who was granted the right to make orders Reichkommissar on this matter. For effective implementation of police protection to everyone the senior chief of SS both police directly and personally subordinated Reichkommissar was sent. Two general commissioners, the chief and regional commissioners chiefs of the SS and police, to full submission (Немецко-фашистский оккупационный режим (1941-1944 гг.). 1965, 125). This accurate system of protection very much reminded the Bolshevist system of supervision of activity of officers during the civil war in Bolshevist Russia and the Great Patriotic War, The political worker known as the commissioner who represented law-enforcement bodies and watched was attached to each of them, the military authorities in the activity adhere to the political line of the party and the Soviet government.

The order in rural districts was provided by police officers. In large settlements there were divisions SS and security parts. It was planned to enter accurate accounting of the local population, which is subject to registration with the police. To Reichskommissariat's inhabitants Ukraine it was forbidden to leave without the permission of public agents places of a permanent residence (Немецко-фашистский оккупационный режим (1941-1944 гг.). 1965, 126-127).

Within July, 1941 Hitler published still a number of directives which gave instructions in methods to deprive of the population of occupied territories desire to resist. 
According to A. Rosenberg, in each commissariat it was necessary to treat to the population differently: "In Ukraine we should begin with cultural affairs; there we have to wake historical consciousness Ukrainian, found the university in Kiev and other educational institutions". Goering rejected this offer: "In Ukraine Germans, first of all have to think of how to receive from it a food maximum". What Rosenberg answered: "In Ukraine it is also necessary to encourage certain aspirations to independence" (Немецкофашистский оккупационный режим (1941-1944 гг.) 1965, 127).

In spite of the fact that Rosenberg planned to pursue a more moderate policy in occupied territories, he was devoted to the business of the "Third Reich", and its real policy completely corresponded to the principles of fascist Germany. The order demonstrating it was signed by Rosenberg on August 23, 1941. He content was about removal of death penalties by special courts to persons who do not want to submit to the occupying authorities. It was noted that the local population had to behave according to laws, given out by the German authorities. As locals were not the German citizens or persons of the German nationality, they were in special situation and were subject punishment for capital punishment or to the conclusion in convict prison (Преступные цели - преступные средства. 1968, 61-63). This order was the eloquent certificate of the real policy of the German occupying authority and reflected a sample of a legislative system of fascist Germany in occupied territories.

An important place occupied by the ethnic question in the policy of the "Third Reich" on occupied territories. The red line there passed the idea of the termination of further biological development of the Slavic people as the nations. This idea took roots into life in the course of positive succession of events for Hitler more and more actively at the front. On "Nurnberg" process there was presented a secret report prepared by the Academy of the German right in January, 1940 in which it was directly said that to exempt "living floor space" from Poles in the Governorate-General and in the western Polish areas attached to the Reich it was necessary to take out from Poland to Germany for the long term of one hundred thousand Poles and thus to prevent their biological development (Нюрнбергский процесс. Сборник материалов в семи томах 1959, 561).

The similar idea was stated also by Himmler in the relation not only the Polish families, but Ukrainian too. In the note "Some Reasons about the Address with the Population of East Areas which was coordinated and accepted by Hitler as directives Himmler suggested to divide the people of "east areas" into smaller branches and groups that would have to lead, according to the author, to elimination of the Polish and Ukrainian nation. 
According to Himmler, in denationalization elimination of the intellectuals and education of the local population had great value, only this way it is possible to turn it into the mass of labor (Хёне 2003, 87).

In the above-mentioned memorandum E. Vettsel "Remarks and offers to the master plan of "Ost" of a Reysfyurer of SS" were accurately checked plans of the Hitler's leadership concerning the population of east regions including the Ukrainian lands. It was stressed that after the victory over the Soviet Union its territory should be planned to move to the remote Areas of Siberia of a significant amount of the Slavic population numbering 46-51 million People, but not 31 million People as it is offered in the plan of "Ost". Eviction had to take place from the territory of Poland, the Baltic republics, Belarus, Ukraine and the European part of the USSR. In this territory, it was planned to leave for use as labor about 14 million People, including 35 percent Ukrainian (Немецко-фашистский оккупационный режим (1941-1944 гг.). 1965, 137).

Plans of resettlement and extermination of the Slavic population were grand. The documents found in archive of security police and Nazi secret service of safety (SD) of Poznan demonstrate to it. These archival materials seemed to be notes of a Gauptshturmfyurer of the CC Herman Krumey being written after the meetings in Berlin in February and in June, 1943 Krum headed so-called "the resettlement center "Vostok" in Poznan and carried out plans of $\mathrm{CC}$ in the occupied Poland. A part of documents coves the Hitler's concept of "resettlement2 of the Slavic people from the territory of the Soviet Union. It was so telling about the population of the USSR: People... These are not people in the European understanding, slaves... To form the big empire, to move in parallel with colonization (according to L.O. Bezimensky "to move" in these documents means "to destroy"). Duration - two or three generations... Further Krum provides the data confirming what number of the population of occupied territories is planned to be moved and destroyed within 30 years: Jews $-100 \%$, Poles $-80-85 \%$, Lithuanians, Latvians, Estonians - 50\%, галичан, western Ukrainian $-65 \%$, Belarusians $-75 \%$. These numbers were given also in respect of Head department of imperial safety of Germany by RSHA (German of Reichssicherheitshauptamt, abbr. RSHA) (Безыменский Л.А. 1981, 271).

A special attention was paid to so-called "ethnic plans" of Hitler's Germany concerning the ethnic minorities living in the territory of Ukraine. Prosecutions and total destruction of the Jewish and Gipsy population of the USSR held a specific place in the policy and the practice of the Nazi occupation regime It was not only "racial question" but because there were the ideological reasons. At the beginning of war Nazi leaders sought to hide a 
little the ominous background of plans of colonization of the Soviet Union. It is visible from the record of the sentence made by a Reykhslyayter M. Norman at Hitler's meeting with the heads of the "Third Reich" about the war purposes against the USSR on July 16, 1941. In legal records there were quoted the words of the Fuhrer: "All necessary Actions: executions, forced relocation and another - we do, despite everything, and we have to it the right. But we do not want to turn needlessly and prematurely any people on enemies.... It is necessary to subordinate whenever possible, rather huge space, it is the best of all to reach it by execution of everyone who will cause any suspicions" (Кенрик, Паксон 2001, 151).

Mass extermination of the Gipsy population in the occupied territory of the Soviet Union was one of aspects of the global racial concept of Nazis and their agents. However the racial criterion was not the basic. Nazis called Roma "dropouts". "The Gipsy question" was considered to be a problem of "a social and ethical order".

In a policy of Hitle's Germany mass extermination of Roma was not such relevant. This ethnic group did not make any global threat. For this reason data about rums were not selected in summary reports on the situation in the occupied territory in a separate point as it became in relation to Jews. Political crimes like sabotage or instigation were never attributed to them. Practically did not remember them also Nazi printing promotion.

However, since spring of 1942 in some cities of a military zone of occupation announcements of registration of rum and their resettlement in special quarters appeared. On June 10, 1942 the chief of security police in Chernihiv published the order about the place of residence of rums which obliged them to get registered under the threat of "severe penalty" in the next policy station for the purpose of resettlement "to precisely certain places which they without the permission of the powerful have no right to leave". This order led soon to mass extermination of the Gipsy population (Бариев 2002, 33).

Historians D. Kenrik, G. Parkinson considered that Nazis pursued first of all nomadic Roma who destroyed not only SS-men, but also troops of the Wehrmacht and therefore they did not get in reports of retaliatory bodies. Destruction of rums of Europe had no system character. Scales of their destruction and prosecution were others, than Jews. According to the order of Himmler dated November, 1942 in Germany it was supposed to leave 5000-8000 Gipsies. It is enough to say that in March, 1943 from 28627 rums, more than 4/5 (20000) lived in the native land (Кенрик, Паксон 2001, 152).

The German historian Margalit considers that not less than 15,000 of them it was succeeded to avoid deportation. By special order of a Reykhskomisar of 
Ostland to the Rod of January 27 and on April 3, 1942 it was explained, occupied on production of rum if do not constitute "social danger", are not liable to destruction (Gilad Margalit: 2001, 43).

In the Slavic and Baltic countries gypsies began to eliminate long before the decision on physical destruction of actually German Gipsy diaspora was made. Even in the Spring 1941 special retaliatory groups which task included the murder of Roma were created. Except professional chastens, SS-men and police persons from among the local population were accomplices of massacre.

Foreign researchers V. Vipperman and M. Zimmerman consider that in the territory of the USSR not less than thirty thousand Gipsies were shot and tortured. As it seems to us, the German documentation does not reflect reality. So, according to reports of retaliatory group the number of the killed rums made 78 people, whereas only near Smolensk several thousands were shot of group of Centre armies. Perhaps, it is the result of the cleaning of archives on the eve of defeat. However, even if documentation of concentration camps and retaliatory groups remained completely, it would not bring final clarity. There is a set of certificates (in particular those who escaped from the German prisoner-of-war camp) that Gipsy the camp, even ordinary soldiers shot on own initiative: each of them knew about full impunity and therefore enjoyed the power over defenseless Roma (Wippermann.; Zimmermann 1996, 374).

It is very important to note that for the extermination of the Soviet Roma in a number of the cities the same methods were used, as at "final decision" of a Jewish problem. For example, in Chernihiv, Kherson, the Crimea genocide was committed according to such scenario: to Roma suggested to be for resettlement in certain points. All who appeared were shot, and then chasteners looked for the separate families which escaped in the rural zone. Also executions according to lists were applied, and the national identity was the only criterion. Well, knowing the fate of the Jews of the occupied USSR, it is possible to draw certain parallels (Бессонов М. 2006, 4-28).

It should be noted racist motivation also. Though in reports of Einzatsgruppen there are national columns "Jews" and "Roma", the Historian M. Bessonov focuses attention on the fact that the last were often included in the category of "dropouts". As Nazis sometimes used social criteria, it gave a reason to deny the genocide of the Gipsy people. On it there are two serious objections (Бессонов М. 2007, 74).

It is impossible to forget that in Nazi ideology the concept "dropout" is treated. Paul Goebbels claimed that the train to the commission of antisocial conducts had been given "from blood". In this way also the theory of "born offenders" (as whom ranked also rum) was treated. Thus, use of the term 
"dropouts", in this case only other verbal packing for the same racial approach (Ржешевская Е. 2004, 34).

It is necessary to draw close attention to practice of the Nazis. On the territory of the USSR Gipsy people as collective farmers and also workers and employees were executed. Also in Germany before "Osventsem" gipsy employees of public institutions, workers, children from shelters and also the men mobilized by the Wehrmacht. were deported. Special methods were developed for the destruction of "defective" races in Germany. There was an Institute of Racial Hygiene. It existed the task connecting with a creation of a full card file on all Gipsy people living in Germany. To solve this problem, the police and the scammers from among the neighbors were involved.

Later on the basis of this database mass arrests were carried out. There was also an ideological justification of genocide. Together with Jews, Romans was proclaimed in additions to the Nuremberg laws by the low race disabled people. Further the decree "About Fight against the Gipsy Threat" was adopted. Of course, the intensity of gipsy elimination does not come within miles of the state anti-Semitism. However, it is impossible to deny that preparation for the destruction of Roma was effective. When the time of "final decision" came, performers have been already morally ready to kill representatives of ethnic minority.

An important place in the plans of the Nazis was given to the Turkic peoples inhabiting the South of Ukraine and the Crimea. Consequences of the first fighting between Germany and the Soviet Union let the Hitler's leadership caused Germany to promote the ideas to unite Turkic peoples on the base of anti-Soviet and the anti-Russian ideology. Nazis leadership used these elements both on the occupied "east" lands and on the territory of the Reich. It became possible a in the countries of Europe and the Middle East too.

At the beginning of 1941 in Berlin plans of use of a Pan-Turkism ideology for association of the "turkish-tatar" people of the USSR under the German flags in the possible military conflict with the USSR were considered. Representatives of national organizations in Germany (the Caucasus, the Volga region, Central Asia) were involved in the MFA in development of practical measures in this direction. However, two heads of the Crimean Tatar emigration which was in Turkey and Poland the relation at first was alerted that had a talk their rather close contacts with structures of the Polish General Staff in the past (Преступные цели - преступные средства. 1968, 21-27).

It is necessary to note the ambiguity in the solution of the "Eastern question" in the Nazi propaganda. On the one hand the invasion of the USSR under the slogan "Destruction of the Bolshevist and Asian knave". In this direction promotion was also formed. Among the military personnel leaflets 
and brochures with photos of the Soviet soldiers of various Asian nationalities with such texts were distributed to a huge number: "There are what TatarMongolian creatures! From them you are protected by the Fuhrer's slider!". Bodies of promotion of CC issued for the German troops as the handbook the brochure "Superman". The people of the East were called on it "dirty, Mongoloids, bestial as bastards” (Преступные цели - преступные средства. 1968, 27).

On the other hand the Hitler's military command sought to use the Tatar population to fight against the Soviet Union. In this regard, the relation to socalled "east" people changed, respectively. An army command demanded that they should show a maximum of respect for them on places. So in the Crimea the commander of the 11th army E. Von Manstein issued two orders in November, 1941. he demanded respect for religious customs of Muslim Tatars and urged not to allow any unjustified actions against civilians. Since October-November, 1941 the Germans began to attract the Crimean Tatars to fight against guerrillas and to form on them self-defense companies (Дробязко 2004, 265).

Creation of representative office of the Ministry of Foreign Affairs at the headquarters of the 11th army in the Crimea became an important element in coordination of work of the Supreme command of the Wehrmacht, the MFA and repressive structures on the involvement of the Crimean Tatars in antiSoviet fight, the duties of his representative were carried out by the leading expert of the MFA major Verner Otto von Hentig (Рекотов 1997, 93).

A great value, according to the German leaders, a little spiritual education of the Tatar population and an explanation for it an essence and the purpose of service in the German army. Wehrmacht manual considered the movement of Tatars as the first push to the general movement of the Turkic people living in the territory of the USSR. A total number of which made up 20.000.000 people. The potential force of these people was highly appreciated not too, but was powerful in the fight against the Bolshevist mode (Органы государственной безопасности СССР в Великой Отечественной войне. 2003, 71).

In the Supreme leadership of Germany the lack of a uniform approach to the fate of the Crimean peninsula supposed to be observed in the future. If a part of employees of the MFA held the opinion in need of providing a certain similarity of autonomy to the Crimean Tatars the guide of CC would demand radical measures for cleaning of the territory of the peninsula from the "disabled" population and its further Germanisation.

In July, 1942. the German leaders finally refused the plan of providing self-government to the Crimean Tatars. On July 27 in a rate Vervolf during a 
dinner with the permanent representative of the MFA of a brigadenfyurer Walter Hewel A. Hitler declared the desire "to clean" the Crimea (Мюллер 1974, 44-46).

The unwillingness of the Turkish leaders to enter the war on the side of Germany became a reason for the termination of discussion of questions about the future status of the Turkic people living in the occupied territories of the Soviet Union. On the Crimean Tatars ceased to look as at a link in the German-Turkish relations.

Thus the German policy for the Crimean Tatars was formed on understanding of need of attracting them to anti-Soviet fight on the one hand and attempts to talk over Turkey in an introductory question in war on the side of the countries of "Axis". However, after the final refusal of Turkey to open fighting the Crimean Tatars ceased to be considered in Berlin as an important element of foreign policy of Germany. Despite substantial assistance of Tatars in defeat of the Soviet guerrilla movement on the peninsula, the top leadership of Nazi Germany developed plans of eviction of these people from the territory of the Crimean peninsula. The peninsula was considered as part of the future Germany at the beginning of the 30th. The German occupying authority under the pretext of the solution of an "ethnic question" of the Crimean Tatars tried to use them as it is possible more effective in the fight against the USSR.

Support of the ethnic Germans living in the occupied countries, especially in the territory of the Soviet Union was one more important aspect of the political concept of the "Third Reich". To this question much attention was paid also by Hitler.

After the meeting with Stalin in Lviv in 1939. he signed the decree about "Strengthening of the German Nation". This decree provided to return the German citizens and a folksdoyche from abroad, to create new German colonies and the new German peasantry. This decree laid the foundation for cruel directives and orders which implementation became fundamentals of the German policy in the occupied territories of Ukraine and other republics of the USSR. According to the decree and other orders conditions for "opposition 2 of the different people in the occupied territory (Koehl, Robert Lewis. 1957, 247).

A. Hitler and his government saw the strengthening of the German nation first of all because of an increase in the German rural population but not only in Germany and in the territories occupied by the German army. In these plans Ukraine was considered to be as the most suitable region for maintaining the German agricultural industry. It assumed a number of the rights and privileges for ethnic Germans of Ukraine, but was also an obvious threat for all 
Ukrainian and other people of Ukraine. To wake in ethnic Germans desire to be citizens of the Third Reich, by the Ministry of national education and promotion of Germany it was developed the whole concept of promotion and information impact on this part of the population of Ukraine.

In this way from first months of the occupation the Hitler's leadership paid much attention to policy to attract to cooperation of ethnic Germans of Ukraine. The Ministry of East Occupied Territories created special department "The Head Political Department" - department of policy for ethnic Germans, special groups for studying of the German settlements in Northern Black Sea Coast. It was created administrative bodies of Reykhkomisariat of Ukraine which introduced policy of the German occupying authority on settlements to a folksdoyche. Special divisions CC $K$. Stamps sonderkommand, a sonderkommand of " $R$ ", the special headquarters of a standard of Genshel directly were engaged in involvement of ethnic Germans of Ukraine in cooperation. Along with administrative instances from a folksdoyche also public organizations - "The union of foreign Germans" worked, - with assistance of which it was created in occupied territories more than 8000 schools for Germans and 24,000 local offices: "The German society on resettlement", "The German academy", "Immigration center", "The organization for strengthening of the German nationality", etc. (Де Йонг Л. 1958, 55).

All public organizations coordinated the activity with official Nazi structures. As a separate link in the structure of the Nazi organizations aynzattskomand worked. One of the main objectives was a protection of the German colonies. As far as ethnic Germans of Reykhskomissariat of Ukraine according to the estimates of P. Reactive quantity to a folksdoyche the course of the Hitler's occupation in administrative education reached from 160 to 200 thousands people. Generally, ethnic Germans of Reykhskomissariat made up about $1 \%$ of all local population (Рекотов 1997, 92).

The position of ethnic Germans-folksdoyche in the occupied territories of Ukraine was defined by the directives of the Reich Minister of East occupied territories A. Rosenberg on February 19, 1942 and the Reichsführer-SS and imperial commissioner on consolidation and strengthening of the German nation and race G. Himmler of September 8, 1942 According to these directives the ethnic Germans living in the territory of Reykhskomissariat Ukraine have to be included in corresponding the national list "Deutsche Volksliste Ukraine". All Germans who were entered in this list were allocated with the corresponding duties, the rights and privileges unlike the Ukrainian population. The rights and privileges received as well members of families of ethnic Germans, especially if they had general children. Depending on purity 
of race, a folksdoyche were divided into several categories: which of family, where all members, ethnic Germans; others from the mixed families; those at whom far ancestors were Germans (Рекотов, 1997, 12).

In this way the policy of the German occupying authority was directed to attraction to cooperation of ethnic Germans of Ukraine. Folksdoyche after the end of war could have become owners in the territories released from the local population.

Summing up the results, it should be noted that the political concept is developed by the leadership of the "Third Reich" represented a complex of views of implementation of policy by the state, public organizations, certain citizens. In Germany conceptual foundations of public policy actually became the doctrine that had been mapped in order to conduct a political struggle and turned into ideology.

The political leadership of the "Third Reich" developed conceptual foundations concerning policy in the occupied territories, in particular the territory of the USSR. Among them: uses of the territory and the available natural resources for strengthening of defense capability of the German army and realization of colonial policy; transformations of the local Slavic population to slaves and their use in the industry and agricultural industry of future German empire with stage-by-stage destruction of bulk of inhabitants of the occupied territory; creating favorable conditions for development of ethnic Germans - "folksdoycha" in the colonized territories.

Information and propaganda activity of the Ministry of National Education and Promotion and the Ministry of East Occupied Territories of Germany and creation of effective information space was directed for realization of the above-stated tasks.

\section{REFERENCES}

1. Hitler A. 1943. Mein kampf, Munchen.

2. Auf antisowjetischem Kriegskurs. Studien zur militarischen Vorbereitung des deutschen Imperialismus auf die Aggression gegen die UdSSR (1933-1941). 1970. Berlin: Deutscher Militärverlag.

3. Айххольц Д. 2002. Цели Германии в войне против СССР. Об ответственности германских элит за агрессивную политику и преступления нацизма. Новая и новейшая история. № 6.

4. Дашичев В.И. 2005. Стратегия Гитлера - путь к катастрофе, 1933-1945: ист. Очерки, док. и материалы: в 4 т. Москва : Наука, Т. 3: Банкротство наступательной стратегии в войне против СССР, 1941-1943. 
5. Гальдер Ф. 1969. Военный дневник. Ежедневные записи начальника Генерального штаба Сухопутных войск 1939-1942 гг. В 3-х томах, 1968-1971. Москва : Воениздат. Т. 2.

6. Розанов Г.Л. 1970. План «Барбаросса». Замыслы и финал Москва : издательставо Международные отношения.

7. Дашичев В.И. 1967. “Совершенно секретно. Только для командования”. Стратегия фашистской Германии в войне против СССР. Документы и материалы. Под редакцией Н.Г. Павленко. Москва : Наука. Москва : Наука.

8. Загорулько М.М. 1980. Крах плана Ольденбург. О срыве экономических планов фашистской Германии на временно оккупированной территории СССР. М.: Экономика.

9. Фрунзе М. 1951. Вибрані твори добутки. Москва : Воениздат,

10. Weltgeschichte der Gegenwart in Dokumenten. Geschichte des Zweiten Weltkrieges 1954. Hrsg. von M. Freund. Bd. II. Freiburg.

11. Schmokel W. Dream of Empire. 1964. German colonialism 1919-1945. New Haven. London.

12. Hitler's Table Talk 1941-1944. Trevor-Roper. London, 1953, 620 p.

13. Замечания и предложения «восточного министерства» по генеральному плану “ОСТ”. Доступ 12 апреля 2014 https://www.warandpeace.ru/ $\mathrm{ru} /$ reports/view/42767/.

14. Der Prozeß gegen die Hauptkriegsverbrecher vor dem Internationalen Militärgerichtshof. 1947. Bd. 4. Nürnberg, Допрос свидетеля Эриха фон Бах-Целевски, 7 января 1946 года.

15. Bd. 38. Nürnberg, 1949. Dok. L-221, S. 92; S. 87 и след. Протокол (Борманн) разговора Гитлера с Розенбергом, Ламмерсом, Кейтелем и Герингом 16 июля 1941 г.

16. Безыменский Л.А. 1981. Разгаданные загадки Третьего Рейха, 1933-1941: Книга не только о прошлом. Москва : Изд-во агенства печать “Новости”.

17. Германский империализм и вторая мировая война 1963. Материалы научной конференции. Комиссия историков СССР и ГДР в Берлине (14-19 декабря 1959 г.). Под редакцией А.С. Ерусалимского. Москва : Изательство. иностранной литературы.

18. Нюрнбергский процесс. 1955. Сборник материалов. 3-е изд. В 2-х томах. Т. 2. Москва : Госюриздат,. Т. 2.

19. «Преступные цели - преступные средства». 1968. Документы об оккупационной политике фашистской Германии на территории СССР. Москва : Политиздат.

20. Hitler's Table Talk 1941-1944. Trevor-Roper. 1953. London. 
21. Нюрнбергский процесс: Сборник материалов. 1988. В 8 т. Т. 2. Москва : Юридическая литература.

22. Немецко-фашистский оккупационный режим (1941-1944 гг.). 1965. Сб. статей. Под ред. Е.А. Болтина. Москва : Политиздат.

23. Германская экспансия в Центральной и Восточной Европе. 1965. Сб. ст. по истории так называемого «Дранга нах Остен», перевод с польского. Москва : «Прогресс».

24. Нюрнбергский процесс. Сборник материалов в семи томах. 1959. М.: Издательство: Государственное издательство юридической литературы, Том 4.

25. Дашичев В.И. 1967. «Совершенно секретно. Только для командования». Стратегия фашистской Германии в войне против СССР. Документы и материалы. Под редакцией Н.Г. Павленко. Москва : Наука.

26. Дашичев. В.И. 2005. Стратегия Гитлера - путь к катастрофе, 1933-1945: ист. Очерки, док. и материалы: в 4 т. Москва : Наука. Т. 3.

27. Хёне X. 2003. Черный орден СС. История охранных отрядов. Москва: Олма-Пресс,: Доступ 17 апреля 2014 http://militera.lib.ru/ research/hohne_h01/index.html

28. Кенрик Д., Паксон Г. 2001. Цыгане под свастикой. Москва : «Текст». Журнал «Дружба народов».

29. Бариев И.И. 2002. Коснулся ли Голокост цыган России? Шунэн, ромалэ. Москва. № 3.

30. Gilad Margalit: 2001. Die Nachkriegsdeutschen und "ihre Zigeuner". Die Behandlung der Sinti und Roma im Schatten von Auschwitz. Metropol Verlag, Berlin.

31. Wippermann W. Op. cit.; Zimmermann M. 1996. Rassenutopie und Genozid. Die nationalsozialistische "Losung der Zigeunerfrage". Hamburg: Christians,

32. Бессонов М. 2006. Геноцид циган України в роки Великої вітчизняної війни. Рома в Україні: Історичний та етнокультурний розвиток циган (рома) України (XVI-XX ст.). Севастополь: Видавництво ТОВ «Спринт-Сервіс».

33. Бессонов М. 2007. Пораймос і Голокост. Голокост і сучасність. № 1.Київ : Український центр вивчення Голокосту.

34. Ржешевская Е. 2004. Геббельс. Портрет на фоне дневника. Москва : АСТ-пресс,

35. Дробязко С.И. 2004. Под знаменем врага. Антисоветские формирования в составе германских вооруженных сил 1941-1945 гг. Москва : Изд-во Эксмо. 
36. Рекотов П. В. 1997. Органи управління на окупованій території України (1941-1944рр.). Український історичний журнал. № 3.Київ : Видавництво Інституту історії України НАН України.

37. Органы государственной безопасности СССР в Великой Отечественной войне. 2003. Сборник документов. Т. 3. Книга первая. «Крушение блицкрига» (1 января - 30 июня 1942 г.). Москва : Издательство «Русь».

38. Мюллер Н. 1974. Вермахт и оккупация (1941-1944). [Пер. с нем. А.Артемова, А.Долгорукова, И.Карабутенко, Ю. Чупрова, Г.Шевченко]. Под редакцией А.Юденкова. Москва : Воениздат.

39. Koehl, Robert Lewis. 1957. RKFDV: German resettlement and population policy, 1939-1945; a history of the Reich Commission for the Strengthening of Germandom. Cambridge: Harvard University Press.

40. Де Йонг Л. 1958. Немецкая пятая колонна во второй мировой войне. Москва : Издательство иностранной литературы.

41. Центральний Державний архив вищих органів влади і управління України. Ф. 3676. Оп. 4. Спр. 230. 


\section{SECTION 2.2. \\ INFORMATION POLICY OF THE SOVIET REGIME ON THE OCCUPIED TERRITORIES OF NAZI GERMANY}

The Soviet Union was formed as a state in which information and advocacy has become the basis of social and political life of the Soviet people. In 1910-1930 s the definition of an information space concept has not yet become significant in European countries, and the leaders of the Bolshevik Party, without having the means of information warfare, clearly understood the importance of the information for the conquest of public opinion to their interests. Therefore, after the October Revolution in 1917, especially with the formation of the USSR, the country started to construct powerful information space.

In 1920-1930s an extensive system of various institutions and mechanisms to influence the social mass was developed in the Soviet Union, whose main goal was to maintain proper world outlook in citizens minds, which partly reflected the reality, was partly mythologized, but what is more important - met specific goals of Bolshevik authorities. Active spiritual, ideological and defense-mass work focused on the formation of the representatives of all nations and nationalities, social groups patriotism within a single country - the Soviet Union and internationalism, all these could not give significant results. Moreover, this is the daily educational activities carried out along with the repressive practices and daily informing the public about the "labor achievements of the Soviet people in building socialism", set peoples patriotic spirit to defend the gains of socialism in the event of military threat or enemy attack.

Ideological education of the masses in the USSR was put on a high level, but the German-Soviet War forced to reformulate and summarize the contents, directions, forms and means of military-patriotic education. Already in June 1941 government speakers in theirs first pubic statements and speeches characterized the German attack on the Soviet Union as treacherous. It was necessary to convince people that the war against foreign invaders was fair. The realization of this idea concluded in people's contribution to increase its forces and raise mass heroism.

It was obvious, that the Soviet state more than any other state in history, paid attention to information and psychological impact of its own citizens. According to P. Kenez, the American researcher, this field was fuccessful due 
to the pre-revolutionary experience of the Bolshevik propaganda, their organizational capabilities and the ability of the political system to isolate the population from alternative ideas and unwanted information. However, P. Kenez noted, that Bolshevik propaganda system was no longer unique: the very ideology has formed the basic guidelines, which covered all areas of life and formed the unfied outlook.

Thus, the advocacy of the Bolsheviks, which was started in prerevolutionary period among the workers and peasants, was their advantage. Later it has become a strong base for the deployment of an extensive system of propaganda including constant attention to the masses and their social life. The Bolsheviks were always close to the people and demonstrated the strength of their ideological beliefs in practice.

Today we can hardly name the country, which power in the first half of the 20th century was carried out in relation to its own population large-scale propaganda activities aimed at imposing ideas that were not perceived by society. Information space that was created in the Soviet Union, was aimed the spread socialism. Very much attention was paid to the creation and dissemination of newspapers as a tool of effective influence on public opinion. This what V.I. Lenis stressed on during is ruling times (Ленин 1967, с. 10). It should be noted that during the raise of Bolsheviks power, the publishings have become a real ideological weapon. The total Bolshevik control included all periodicals, radio, literature, education and science, in fact, - daily life of every citizen of the USSR.

According to the numerous documents of those times, the pro-government forces in both countries - in Germany, and the Soviet Union - sought to create a totalitarian system with continuous control of public opinion. Management mechanisms were similar in the two countries, just as mechanisms of mobilization in defense of each country.

The hard struggle with the Soviet Union over Nazi Germany in 1941-1945 led to information confrontation between these countries and the implementation of modern means and methods of ideological confrontation. The Soviet society was taught to hate fascism more and more and to identified it with cruelty, evil, violence and cynicism. The USSR was a powerful political propaganda industry. The word "German" was identified with the word "enemy" thanks to I.Erenburg who made great efforts to this. At a time when Hitler's propaganda showing Stalin and the Soviet leaders as stupid and criminal people, Hitler was depicted on the Soviet posters as a pathetic, cruel dog or snake, killed by a Soviet warrior.

DuringGerman-Soviet war the Soviet propaganda has performed a lot of functions and broadcasted many ideological installations. It is clearly shown 
on the example of the term "Great Patriotic War". No doubt, it was a propaganda instalation that had become the basis of the concept of information and propaganda war of the USSR. Right this phrase had to hide the complicity of the Soviet Union to Hitler's aggressive campaign, which lasted until June 1941. Since the beginning of hostilities in the USSR, its leaders tried to convince the public that the war waged by the Soviet Union with Nazi Germany, is national, liberating and fair. In particular, the decree of People's Commissar of Defense, published in May 1942, included the following: "We have no such purpose, to seize foreign countries, to conquer alien peoples. Our aim is clear and noble. We want to liberate our Soviet land from the German fascist scoundrels. We want to free our fellows - Ukrainian, Moldovans, Belarusians, Lithuanians, Latvians, Estonians, Karelians from that disgrace and humiliation to which they subjected the German fascist scoundrels. For this purpose we have to destroy the Nazi army and exterminate all the German invaders..." (Сталін, 1952).

The same order stated that the Soviet leadership had no such purposes as the Nazis had, that it does not seek to impose it will and regime to Slavonic and other enslaved nations of Europe. There is no intend to interfere the internal affairs of other nations (Сталин 1952).

The method of fasteninf systems was often used in military reasons, based on the fact that the perception of people is very limited due to their small amount of operational memory. That person did not have time to process a large mass of data and the excessive amount of information perceived as chaos. That's why, during ideological impacts, simple expressions plan an important role such as: "Everything for the front! Everything for victory!","Ukraine has been and will be Soviet", "Glory to the great Stalin the leader and friend to Ukrainian people!" and many other bright slogans (Центральний державний архів громадських об’єднань України. Фонд 1). The concept of "Patriotic War" is well-known in world history and appeals to the senses of man to an innocent victim, who traditionally and in new conditions has the right to take part in "Great Patriotic defensive War". Although it's hardly possible to call the war between Germany and the USSR the "Patriotic" one for all Ukrainians, even knowing how many million people were in concentration camps, in captivity as political prisoners and built fortifications under the muzzles of machine guns.

The leaders attitude to the Red Army worriors, who fell into captivity, was really impressive. This clearly demonstrates the decree of the Supreme Command of August 16 $6^{\text {th }} 1941$ № 270. This document stated, that the Red Army, surrendered by the enemy, must be "destroyed by all means, both by land and air, and Red Army family, who surrendered, must be deprived of 
state aid". The order of People's Commissar of Defence of the USSR of July $28^{\text {th }} 1942$ № 227 included the importance of the formation of "armed enclosures" (up to 200 people in each) emphasizes the need to develop "armed zahorodzahoniv (up to 200 people in each)". The decree also contained the information to place them "in the immediate rear of unstable divisions and oblige them in case of panic and disorderly retreat of division parts to shoot on the spot all cowards...” (Король 2002, 51).

This situation shows that, on the one hand, not all soldiers understoond what was happening, why the Red Army retreated. They were not ready to defend the regime that has brought so much grief to most of their families. On the other hand - the order pointed out that the Bolshevik government and the leaders of the Red Army did not trust its own soldiers and commanders, the defense of "Homeland" has become a compulsion to many of them.

Since June 1941, when the fascist German army started to occupy the territory of the Ukrainian SSR, its advocacy activity was quite effective and therefore could withstand the advocacy work of Soviet propaganda activists. But since December 1941 the effectiveness of information-psychological influence of the invaders started being less intensive, as a result of the confrontation methods ofs Soviet leaders.

The Soviet Union reacted on Hitler's information attack already in early days of the USSR western regions occupation. On June $23^{\text {rd }}$, 1941 GHQ was established and on July $17^{\text {th }} 1941$ the Main Political Directorate of the Red Army was founded. In accordance with the directives issued by this Department, the main task of military press was to train heroism, courage, martial arts, discipline. The press used specially formulated slogans, such as: "Fascism - is the enslavement of peoples. Fascism - a hunger, poverty, bankrupt. All forces should be aimed at the fight against fascism!", "We are for the right actions. The enemy will be defeated. Victory will be ours!". In the first months of the war such slogans determined the contents of leading military and civilian newspapers. (Панарин 2006, 18)

The next step in Stalin information policy was to create an information mechanism to ensure the GHQ. The mechanism of managing information was created. On June $24^{\text {th }}, 1941$ the joint decree of the Communist Party and the government of the USSR "On the establishment and tasks of the Soviet Information Bureau" was legislated. The same resolution defined the main tasks of the newly created outreach departments, namely:

- Guidance to coverage of international events and domestic life of the Soviet Union on radio and in the press;

- Organizing counter-propaganda against the German and other hostile propaganda; 
- Coverage and hostilities at the front, preparation and publication of reports on the materials of military Command.

Throughout the period of the war, information agencies were the main sources of information of the situation at the front both in Germany and in the Soviet Union. Sovinformburo messages were the most valuable for the citizens of the USSR, which came up directly from the Supreme Command, as well as major newspapers, which hired correspondents of Sovinformburo.

An important mechanism for the formation of the Soviet information space among the soldiers of the Red Army and the population of temporarily occupied areas were linguistic and stylistic means, which undoubtedly influenced the minds of people like emotive words and linguistic expressions, epithets, comparesons etc. which had the status of permanent. They were often used as headlines in newspapers and leaflets, which were dropped from aircrafts to the occupied territories. In particular, these are some words and expressions, which characterized Soviet soldiers: "fighting brotherhood", "ingenuity and courage", "initiative commander", "courage", "their" and so on. In contrast, the image of a brave Soviet soldier had an image of the enemy, which was wittingly negatevily described with the help of stained words and phrases: "terrible atrocities", "atrocities of the Nazi monsters", "massacre of the Nazis", "Crimes of Nazi thugs" and others. In proverbs and sayings which appeared during the war, invaders were compared with evil invaders, exotic animals, representatives of evil spirits, creatures from the other world. The newspapers and leaflets often published even swear words "cheater", "bandit", "proydoha", "Scarecrow" and others (Советская пропаганда в годы Великой Отечественной войны: “коммуникация убеждения" и мобилизационные механизмы 2007, 19).

A good example of propaganda texts of those times, which combines positively and negatively stained words and linguistic expressions can be allocution of the Commander of the South-West direction and the CCCP (B) to the population of the occupied territories with a call to fight against the Nazis: "The Nazis have seized part of our native Ukraine. They captured and your neighborhood also, and now German boots trample native land. Intrigue, betrayal and cunning helped the enemy to manage it in the first months of the war. In the occupied towns and villages the invaders celebrate bloody feast: they rob, kill, rape women and even teenage girls, take out everything valuable. German fascists want Ukrainian people to become the German one. They want to turn Ukraine into a colony, and you - to become slaves". (Русский архив: Великая Отечественная) As we see, polititians of 1940s well understood that any war is impossible without appropriate information 
actions. In their opinion, the wars "should be fair, an enemy - cruel, own soldiers - real heroes “ (Почепцов 1998, 34).

The powerful information campaigns took place already from the beginning of the deployment of hostilities on both sides, whose purpose was primarily to discredit the enemy, the creation of an enemy. The main objective of informational war was to demonstrate the advantages of country's armed forces, concealing their own loss, exaggerating the losses caused by hostile armies, military and industrial facilities and means of communication, including enemy's radio stations. Thes the information distributed through military-controlled press and radio.

The next important step in strengthening the information policy of the Soviet Union was the propaganda of extreme vigilance. On June $29^{\text {th }}, 1941$ the SNK and CC of the CPSU (b) derective was issued by party and government organizations of frontline areas. Its contens was brought to the public on July $3^{\text {rd }}, 1941$ through the speech of Stalin. The document stated the need to organize a relentless struggle with various disorganizers, like deserters and alarmist, and those spread rumors. Spreading rumors was often defined as a crime and fell under the appropriate criminal penalties. At the same time distributed pamphlets and other propaganda materials, which explained that the spread of false rumors was a "moral sabotage", which could be primarily interested by enemy (Коммунистическая партия в Великой Отечественной войне 1970, 42).

To coordinate and manage the information streams, which sprang in the rear and on the occupied regions of the USSR, the Office of propaganda and agitation of the CPSU (b) has created five new departments: radio and radio information, advocacy groups, literature, cinema, arts (Коммунистическая партия в Великой Отечественной войне 1970, 42). Each department was self-sufficient entity, and industry was completely controlled and subjected to total censorship.

According to the plan "About the work behind the enemy lines, approved by main political administration of the Red Army plan, there were defined following tasks from November 1942 to September 1943”: (Центральний державний архів громадських об'єднань України. Фонд 1, 68)

1) distract the Germans and attract the Soviet citizens who were under the influence of German propaganda and for various reasons appeared in enemy camp, at the police service, the gendarmerie, the so-called Cossack detachments of "Russian Liberation Army", etc.;

2) to mobilize the population to prepare for a national uprising against the occupiers, to extend the armed struggle of the occupied areas against the Nazis; 
3) to organize a mass boycott of all activities of the Germans during the seizure of areas;

4) to strongly promote the success of the Red Army, the soviet front and thereby give hope to close the liberation from Nazi rule.

The Soviet Information Bureau has become an accumulation and dissemination center of important information. But to conrol the information flows and to prevent unauthorized listening and hostile foreign radio broadcasts, on August $23^{\text {rd }}$, 1941 I. Peresypkin, the Deputy Commissar of Defense, issued the decree about the verification of the implementation of Council of People's Commissars of the USSR dated June $25^{\text {th }}$, 1941 № 1750 , according to which all citizens, living in the Soviet Union, were obliged to hand over personal radios to local connection authorities (Русский архив: Великая Отечественная 1997, 72).

Soviet Informbureau, in accordance to the basic activities, constantly managed coverage of international events and domestic life of the Soviet Union on the radio and in press, organizing counter-propaganda against the Nazi media, publishings of military reports by materials of the Command of the Red Army. Sovinformburo also guided activities of anti-fascist and Slavic committees created at the beginning of the war: Soviet women, youth, scholars, Jewish Committee (КПСС в резолюциях и решениях съездов, конференций и пленумов ЦК 1985, 213). Since 1942 vector of the Soviet Information Bureau was radically changed and focused mainly on communication with foreign media, public and political organizations. For this purpose, 11 departments were created in the structure of the information and propaganda agency (Советское Информационное Бюро в годы Великой Отечественной войны 1999, 59).

The most difficult task was to inform the world community about events which took place on the Soviet-German fronts and on the work of the home front. The Soviet Information Bureau had no connections with the international information space. It was necessary to form new ones. Opponents of the Soviet Union, including Germany, had a powerful propaganda apparatus, had a large number of radio stations, newspapers in major European countries. The Soviet Union allies quickly created a powerful information and propaganda organ. The Soviet Information Bureau faced tough task: to develop and maintain relationships around the world, to use all available methods - newspapers, magazines, radio stations, agencies, etc., to transmit official information about the Soviet Union and the events which took place in the country.

Sovinformburo let the readers and listeners from abroad know to fight for the Soviet army and people against Hitler's army through 1171 newspapers, 
523 magazines and 18 radio stations in 23 countries (Советское информационное бюро 1944-1945).

Radio programs Sovinformburo such as "In the last hour", "The construction of the Soviet Information Bureau", "Letters from the front and the front" and others were available for listening to almost every citizen of the USSR, although the radio points worked with major interruptions. Operational summary of Sovinformburo was published daily from June 25, 1941. News from the front was gatherd from $5 \mathrm{am}$ to $6 \mathrm{am}$. Sovinformburo reports were always published on the front pages of Soviet newspapers. They were the main sourse of spreading information in almost every town.

At the beginning of July1941 the Informbureau Soviet Berau together with All-Union Radio Committee, conducted a new form announcing information, which has not been used in practice before. It was regular radio transmission of political reviews. At first they were broadcasted only on the territory of the USSR, and later for listeners abroad. The reviews were broadcasted once a week (later - twice) at a specific date and time named "Averin". In fact, their authors were a few dozen of people: Yaroslavsky, Pik, Omelchenko, Varga, Zvavych and others- 30 people on total. The certain Comintern officials were hired to work as commentators. Even more, thanks to the People's Commissariat of Defense there were involved officers to prepare articles, who were treated in hospitals, as well as those who were sent from the front. These materials were sent abroad after Informbureau Soviet literary group processings. Commentators work seemed impossible without the efforts of the authors and compilers of the texts. All of them were united in the Literary Sovinformburo Department. During July - October 1941 the department's staff prepared and sent abroad around 140 articles. Soinformberau has prepared more than 400 articles during this period together with specially ordered materials for newsletters of England, the USA, China and Sweden (Салата 2009, 117).

The management of Sovinformbureau in conjunction with the All-Union Radio Committee was worked out clear requirements for the contents of all materials which were broadcasted on the radio. The messages of Soviet Informbureau were based on some clear pattern. First, there were summed up the battles for different directions, then - figures of destroyed equipment and manpower of the enemy, then - losses of Soviet troops (sometimes this order was violated). The morning digest contained the last night events, and the evening issue expressed analyzed results of hostilities during the day. From the first day of the war correspondents provided descriptions of battle scenes and exploits of Soviet soldiers. During the German-Soviet war, 14470 names of the soldiers were announced, who distinguished themselves at the front 
(Советская военная энциклопедия 1979, 415). Together with this, in shoul be noted that sometimes daily and summary reports from the fronts were false and biased, that even Stalin did not believe in them (Сообщения Советского Информбюро 1944-1945, 3).

The information, provided by Sovinformburo, was immediately published in newspapers and leaflets, which were later distributed on the fronts and on the occupied territories by the German army.

The information materials, submitted in messages, were subjected to strict censorship. Despite the specific requirements regarding the Informbureau materials which were allowed/probihited for publishing, the editors had to make adjustments in messages, or to publish it in the way which absolutely did not meet basic line of Soviet information and political propaganda.

For example, the "Komsomolskaya Pravda" newspaper contained "The Spring", essay by Iyulsky, in which the author, following the requirements of propaganda, showed the situation in the besieged Leningrad as if life on the streets and boulevards of the city was in rush, kids played in the gardens etc. Despite shells and bombs bursted nearby, noone paid attention on them. This information was designed for soldiers of the Red Army and the population of the occupied territories, who had to believe that the German army could not break the spirit of the Soviet people that their whole life has changed and keep on moving forward. But if this essay was read by Leningrad residents, who were starving and dying from cold in the besieged city, they would be very indignant, and who knows how it all could be finished (Советская пропаганда в годы Великой Отечественной войны 2007, 156).

The "Izvestia" newspaper stopped publishings of "Fuel is delivered on time" by A.Kuznetsov, correspondent. To show the courage and heroism of Soviet railroad workers, the autoher mentioned in the article the amount of destroyed railway stations, broken trains, damaged tracks etc. One part of this correspondence should have had positive influence on the population and the soldiers of the Red Army, but the rest would support the creation of German Informbureau, but it could bot be allowed to happen.

Due to different reasons, 65 articles and essays have been canceled in such newspapers as "Pravda", "Izvestia", "Komsomolskaya Pravda", "Red Star", which covered the main events of war (Русский архив: Великая Отечественная 1997, 157).

To make Soviet broadcasting more accessible to all social groups of different nationalities, on November $17^{\text {th }}, 1941$ according to the Decree № 904 by the State Defense Committee, there was approved the mandatory radio broadcast in Ukrainian and in Polish. To this end, it was ordered to use one radio in October broadcasting center in Moscow for 12 hours a day to 
perform Ukrainian radio and oblige Broadcasting Committee to finish the installation in Engels one of the radio tools, taken from evacuated Kharkv, till December 3, 1941.It was specifically intended for radio broadcasts in Ukrainian and Polish (Русский архив: Великая Отечественная, 25).

Based on the above, we can state that Sovinformburo leaders faced great difficulties with recruitment: they were required language skills, experience in advocacy and peronl information. The particular attention was paid to the selection of correspondents who worked with foreign newspapers and agencies.

The military propaganda held abroad, played an important role in work of the Soviet Information Bureau. Thus, the report of the Soviet Informbureau of 1941-1943 showed that this department daily controlled and supervised 22 central newspapers, all military correspondence Tass and Radio Committee, TASS pictures, publishing products. This correspondence was sent to England, USA, Sweden, Turkey and Iran, which helped to adjust direct relationships with the US military magazines (Сообщения Советского Информбюро, 1944-1945, 258-259).

The government and the main political administration of the Red Army understood that to announce the information to the public in such a way was very dangerous. Therefore, the daily combat Sovinformburo construction took a long way from the General Staff to the speaker of Radio Committee and its text was significantly changes. Sovinformburo management adhered the rules under which the loss ratio had always been in favor of the Red Army. According to these claims, the messages dated June 22-24 ${ }^{\text {th }} 1941$ about the downed aircraft, mentioned that the Soviet Air Forces lost 374 aircrafts, and the Germans - 381 (Сообщения Советского Информбюро, 1944-1945, 4). On June $25^{\text {th }} 1941$ it was reported that the Soviets lost 17 aircrafts, and Germans -76 . June $30^{\text {th }}-21$ lost Soviet aircraft and 102 German airplanes (Сообщения Советского Информбюро 1944-1945, 5). To check this data in the offices was wery difficult, that's why the worriors could not understand why such large army losses were presented as a victory.

Another eloquent example proves, that the information, supplied through Sovinformburo, did not always reflect the true events that took place at the front. So, we know that during the defense of Sevastopol, compounds remains (109th Infantry Division, 142nd Infantry Brigade, 4 consolidated battalion in total about 5.5 thousand people) under the command of Major General P.G. Novikov kept on fightings. They were not mentioned in vaults at all. In such circumstances, soldiers and officers completely lost morale. And it effected the situation on the front. Such cases were not rare. The control over events at the front was lost quite often, and whole units dropped out of sight of command, resulting their commanders to operate on their own. 
The Sovinformberau message shows the relation of the command to combat groups of the the Red Army, as the Soviet troops left the Sevastopol on July $3^{\text {rd }}$, 1942, which (the message) also contained the following: "The Soviet troops losses during June $7^{\text {th }}-$ July $3^{\text {rd }}$ : 11385 people killed, 21099 people - wounded, 8300 - missing, 30 tanks, 300 guns, 77 airplanes. Soldiers, commanders and wounded people were evacuated from Sevastopol" (Сообщения Советского Информбюро, 1944-1945, 284). However, we know that these data was not true. In fact, according to the reports declared by P.Oktyabrsky, the Chief of the Defence of Sevastopol district, the commander of the Black Sea Fleet, Vice Admiral, to the General Headquaters on July $9^{\text {th }}$ 1942, the total number of Soviet troops amounted to 130125 persons, the losses - 31068 people, injured - 17894 people, those who died in field hospitals -1207 people. Knowing these numbers, it is easy to count the number of defenders of Sevastopol, the remained - 79956 people. Almost 80 thousand soldiers and sailors who heroically defended Sevastopol were forgotten and doomed to death (Меленберг, 200).

When Hitler's troops almost captured Kyiv and Soviet troops retreated, there were no reports from Soviet Informbureau neither on $19^{\text {th }}$ nor on $20^{\text {th }}$ of September 1941 about it. All that we know about Kyiv of these days is: "During the night of September $20^{\text {th }} 1941$, our troops were fighting the enemy on all fronts". As a result, major Kyiv residents and people from the suburbs had no time to evacuate (Меленберг, 200, 74). And later, those, who did not evacuate from the area of German occupation, were called "traitors at the national level".

Instead, we read in the same statement about Soviet soldiers freed villages in Smolensk region from the Nazis, about Bosnia and Herzegovina that keeps on fighting between Yugoslav rebels and Italian troops, about good harvest in the Omsk region and Altai Territory and other regions of the Soviet Union (Сообщения Советского Информбюро, В 8 т. 1944-1945, 74).

Despite the messages in the government newspapers, they published articles with authors, summing up weekly news or other hostile period. They wrote about about a significant advantage of the Red Army over Nazi troops, urging the population and the soldiers of undeniable victory of the Soviet troops. As an example, an article written by A.S. Shcherbakov "Hitler deceives his people", which was published in the newspaper "Pravda" on October $5^{\text {th }}, 1941$ and broadcasted by Sovinformburo on air (Великая Отечественная война 1941-1945: Энциклопедия, 640). The draft of the article stated: “... the loss of the Germans near Leningrad - 105 thousand"; but after revision of A.S. Shcherbakov the figure was 140 thousand. In the draft we can see: "... it was documentaly proved that during three months of war the 
Germans had lost 11,100 tanks, about 13200 guns, 10000 aircrafts, the Red Army inflicted 3-4 times more damage to the enemy". The final "3-4 times" were corrected to "2-3" and deleted the phrase "documentaly proved" (Советское Информационное Бюро в годы Великой Отечественной войны 1999, 37). There were also removed outright expressions and some German losses were understated for 3 months of the war the Germans lost more than 11 thousand tanks, 13 thousand guns, 9 thousand aircraft and more than 3 million soldiers (Советское Информационное Бюро в годы Великой Отечественной войны, 1999, 39). It should be noted that in service in the Wehrmacht did not have so many tanks. Comparing Soviet losses to German ones, the first ones looked more optimistict: " 1,128 thousand in manpower, about 7 thousand tanks, 8,9 thousand Guns, 5,316 aircrafts" (Советское Информационное Бюро в годы Великой Отечественной войны 1999, 41)

Comparing Informbureau messages to the figures of the Soviet military losses in A.S. Scherbakov records, we can conclude that digital material reports did not meet reality but consisted of propaganda purposes. All these events created the image of the invincible Soviet Army for the Soviet population, who worked behinf the enemy lines or was in the zone of Germa occupation; the Army, which could not be defeated.

The last issue of "The Great Patriotic War of 1941-1945" encyclopedias edited by M.M. Kozlov, contains the information that the German Arm lost in November 1941 only 750 thousand people (Великая Отечественная война 1941-1945: Энциклопедия 1985, 13.). The studies of M.I. Meltyuhov shows that the Germans before the war with the Soviet Union had only 3899 tanks and 4841 aircraft (Мельтюхов 1991, 18). Thus, it appears that the article of the Soviet Information Bureau and propaganda leaders, of A.S. Scherbkov in particular, showed that German military units were destroyed almost two times more than it was in reality.

Similar technologies were also used by Nazi propaganda. Wehrmacht Supreme Command spread the information on the occupied territories about the huge losses of the Red Army and downplayed self losses at the front. This information was distorted to maintain the morale of soldiers and to hide the true figures of Wehrmacht losses on the Eastern Front. Propaganda departments made stories about "the Red Army defeat", about the number of captured Soviet soldiers. With the help of misinformation, the enemy tried to influence the Soviet soldiers, on the population of temporarily occupied areas of the Soviet Union and the global public opinion.

To somehow counteract Nazi propaganda, the Soviet leaders launched counter-Informbureau: only during the first six months of the war there were published over 15 major materials (1941-1945. Публицистика и очерки 
военных лет, 1982, 74). In its publications the Informbureau disclosed methods of counting enemy losses of Soviet tanks, planes, guns and more. The collection contains many other data that make an undeniable interest to historians.

The influence of the ideological concept of the party on the activities of the Soviet Informbureau leaders was deliberately determined. The situation of that time forced the editors and reporters to carefully follow certain rules, such as: the Soviet system - the fairest system in the world, all the Soviet - the best in the world, the Soviet people - the freest, the proletariat of other countries certainly oppressed etc. Deviation from established ideological postulates led the person, accused in it, to the rank of enemies, and then - to the repression. It happened with a group of employees of the Jewish Antifascist Committee. When its influence on the international community increased, the committee was dissolved at the end of 1948, and many employees were arrested. They spread the blame of anti-Soviet information. Military Collegium condemned 13 people to death (В комиссии Политбюро ЦК КПСС, 1989, 38).

Studying Sovinformburo work during the Great Patriotic War, we can conclude, that:

1) Soviet Informbureau had become a powerful tool of counterpropaganda of the Red Army and the population of the occupied territories;

2) the formation of an information space on the occutpied territories took an important role in the activity of the Soviet Information Bureau, where all the messages were delivered in newspapers or leaflets;

3) Foreign political propaganda and dissemination of information "from the first hands" to the United States, Britain, Turkey and other countries was an important aspect of its activity;

4) the materials of Sovinformburo during hostilities served as an information and advocacy function, so that all materials tested and contolled by main political administration of the Red Army to follow the ideological and propaganda requirements.

In general, it should be noted that the materials, that indicate the activity of the main body of Soviet propaganda - the Soviet Informbureau, make it possible to expand scientific research on the World and the Great Patriotic War and answer important questions. They help to explore the methods and mechanisms of Soviet information space on the occupied territories of the German army.

Messages to the areas, temporarily occupied by German fascist invaders, were broadcasted through Ukrainian radio stations. Thus, the most popular among them was the station of Taras Shevchenko. It should be noted that the broadcast was intended mainly to working-age population of temporarily 
occupied areas of the Soviet Ukraine, in particular its most active representatives - guerrillas. Broadcasting was based mainly themed, namely:

- Systematic coverage of the heroic struggle of the multinational Red Army, including sons and daughters of the Ukrainian people, who fougt in its ranks for the liberation of all temporarily occupied Soviet lands from the German yoke;

- Show selfless labor on the home front, inspired by high noble aim to defeat the German invaders;

- A wide and systematic show of Stakhanov work on evacuated enterprises and collective farms, further development of Ukrainian science, culture and art in the Soviet rear;

- Show courageous struggle of Ukrainian people's avengers - partisans behind enemy lines, unfolded under the slogan "Ukraine has always been and always will be the Soviet state";

- Systematic coverage of the terrible Nazi hordes on the occupied Ukrainian lands, exposing their man-hating program extermination, enslavement and Ukrainian people's transformation into German ones, the destruction of national culture and science with its historical and cultural relics (В комиссии Политбюро ЦК КПСС, 1989, 1).

Particular attention was paid to radio message created already during the war: "Soviet Ukraine", "partisan" radio station by Shevchenko and others. These stations were used by the Soviet government as mechanisms of propaganda-agitation direction. Their activity on the occupied territories of the Nazi army was especially active (Центральний державний архів громадських об'єднань України, фонд 1, 23).

The overall volume of Ukrainian Radio Committee was 19 hours 35 minutes daily, which included: 6 hours 25 minutes of Moscow relaying transmissions, 12 hours $35 \mathrm{~min}$ of personal broadcast. The prodaganda and agitation department was given 2 hours and 28 minutes per day (the rest of the time was used to create the desired mood of the population) (Центральний державний архів громадських об’єднань України, Фонд 1,2).

Radio broadcast of propaganda and agitation departments was based on appearances, speeches and orders of Stalin and others. Promotion of these documents, the impact on the Soviet people on the occupied regions of Ukraine and directing them to fight against the German invaders - all these issues covered all leading positions in broadcasting.

During 1942 the department of propaganda and agitation has announced about 2 thousand papers, correspondence, individual notes, out of thi amount - more than 1,500 original articles and correspondence. 
The majority of radio programs were dedicated to the famous Red Army heroism, wisdom and courage of the Soviet people. In order to fulfill this task, special articles were ordered and organized the systematic performances on the radio to the people on the front. The articles were about some combat operations of units, departments, military units of the Red Army, the heroism in the fight against the German invaders. Among them there were such programs: "The power of Stalin's prediction", "noble, lofty goals Patriotic War", "Infinite heroism of Sevastopol people calling on the exploits", "In the name of the motherland", "For you, Ukraine" and others (Центральний державний архів громадських об'єднань України, фонд 1, 3-4).

A large number of transfers was devoted to the Communist Party and its leaders - Lenin and Stalin. The Party was hown as the only power that organized the Soviet people in the struggle against the Nazi invaders. Such programs constantly emphasized that the Soviet people always win just because of its great leader Stalin.

On November $23^{\text {rd }}, 1941$ "Latest news" radio station resumed its activities which continued to broadcast radio programs in Ukrainian cites from Saratov. During 1942 this radio station daily broadcasted six editions of the latest news, two issues of "News from the fronts of World War II", two issues of "guerrilla news", two issues "the newspaper" (Центральний державний архів громадських об’єднань України, фонд 1, 8).

The "Ostanni Visti" newspaper was focused on such issues:

- Official reports;

- Soviet Informbureau messages;

- TASS correspondents' and central newspapers' messages;

- the information from abroad about struggle of oppressed peoples against Nazism, about mighty coalition of great powers - the USSR, the Great Britain, the USA;

- Message from the World War II fronts;

- News from the Soviet motherland (Центральний державний архів громадських об'єднань України, фонд 1, 11).

Printed and visual materials were not as operative as radio programs, and therefore could not fully perform its functions.

To defeat the enemy in the information confrontation, Chief Political Department of the Red Army also stepped up its activities in countering German advocacy attacks. On August $19^{\text {th }}, 1941$ all military councils and fronts' chiefs were sent the directive "About the work among with the population of the occupied areas and the party-political leaders of the guerrilla movement" (Бурцев, 1981, 104). This step of the Soviet government testified that the outreach military policy factor was of great importance to defeat the 
enemy. According to this directive, in the Main Political Department of the Red Army and in front political directorates there were established relevant departments, and in the political department of the army - similar departments. Their main task was to conduct information flows and propaganda among the population of the occupied areas and the guerrillas, to improve the experience of information warfare. These departments existed in the structure of the Main Political Directorate of the Red Army till September 1942, and then refered to created headquarters of the guerrilla movement.

According to the directives instructions, the departments of party-political work among the people and the Red Army, which worked on Soviet territory occupied by the enemy, assigned certain responsibilities:

- to send their representatives to the enemy lines to guide the work of the occupied areas of the Soviet political management and guerrilla movement;

- to publish special literature (monuments, cards, addresses, etc.) and distribute them among the population of the occupied areas, among guerrilla groups formed by local people distribute "News from the Soviet Motherland" issued by the Chief;

- to organize daily radio broadcast for the population of the occupied areas;

- to provide central and local periodicals to the occupied areas through its daily delivery to nearby areas with specially selected people and drop it from the aircrafts to remote locations (Русский архив: Великая Отечественная, 1997, 24).

The issue of leaflets and bulletins started on August $18^{\text {th }}, 1941$ in Russian, Ukrainian and Belarusian. During the war 681 different newspapers were published with a total circulation of about 510 million copies, including in Ukrainian - 112 newspapers (about 35 million copies). These types of printed campaign expressed the situation on the Soviet-German and other fronts in the Soviet rear and on the occupied territories etc. Thus, one of the bulletins dated January $22^{\text {nd }} 1942$ stated: "Dear brothers and sisters from Soviet areas, temporarily occupied by German troops! Hitler's soldiers hide from you the fact of the defeat of German troops and spread false messages about our country. Do not believe fascist dogs!" Postcards call all learn the truth about the Red Army and the real events occurring at the front, from Soviet newspapers and leaflets (Чайковський, 1990, 301).

The bulletins contained the events, which took place in the front and in the rear of the Soviet army at this time. There was the review of foreign press about the defeat of German forces at Moscow, reports on the status of military production in the countries - allies of the USSR, the activities of the guerrillas and their subversive activities and so on (Чайковський 1990, 302). 
To increase the informational confrontation and reduce the pressure of Nazi propaganda on the population in the rear and on the occupied territories, the Soviet management started the rapprochement with the Russian Orthodox Church. Stalin, realizing tremendous unifying and spiritual, ideological role of the Russian Church (and it was the outlet for the entire territory of the USSR), initiated the restoration of the patriarchate. Before this, the huge funds collected to help the church in front of armored columns, aviation equipment etc. were a motivative factor. On the first day of the war, Metropolitan Sergiy blessed the Soviet people in his message to "defense of the sacred borders of the motherland." The next step in this policy was the closure of anti-religious periodicals. The "Union of the Godless" was also dissolved. Its editor was Yemelyan Yaroslavsky (Hubelman). In 1943 Stalin agreed to elect the patriarch. It was the Metropolitan Sergiy. Since then the church has began to actively use "moral justification for war" conducted by the Soviet Union against fascism (Советская пропаганда в годы Великой Отечественной войны, 2007, 20).

By strengthening its position in the information space, the State Defense Committee formed Command Headquaters of the partisan movement at Central Headquaters on May $30^{\text {th }}$, 1942. P.K. Ponomarenko was a head of the CPSU (b) Belarus. In accordance with the directives of the Main Political Directorate on September $28^{\text {th }}, 1942$ the Political Department was founded and connected to the Central Staff of the partisan movement, headed by B.I. Malin, the secretary of the CPSU (b). The main task of this administration was to widespread deployment of agitation and propaganda work among the population of lands temporarily occupied by the Nazis. At the same time the Political management gave orders to all its structural subdivisions to organize oral propaganda and counterpropaganda, and also publications and distribution of printed leaflets etc (Волковский, 2003, 392).

The protocols № 6-10 of the subterranean meetings of Communist Party (Bolsheviks) dated $29^{\text {th }}$ January $-30^{\text {th }}$ April 1943 we can see that the leaders of Bolshevik subterranean organizations performed a strong agitation and propaganda work among the population on temporarily occupied regions of Ukraine. They carried out not only the dissemination of information about the plight of the population and its slave labor, but also to ensured by the collection of materials from the occupied areas for processing and using information as a weapon against themselves as occupiers. The members of the subterranean studied, systematized these materials in order to use them for counter-propaganda (Центральний державний архів громадських об'єднань України, фонд 1, 117-124) 
Not remained aloof and Komsomol governing bodies did not remian asside. The Decree of the Central Committee of Komsomol about measures of Komsomol organizations on the temporarily occupied areas we can see which activities they performed among the local population: they widelyspread printed and oral propaganda aimed to strengthen the faith of young people in the victory of the Soviet Union, they increased production of leaflets on practical issues of guerrilla warfare, they popularized folk heroes, destroying traitors etc (Русский архив: Великая Отечественная, 1997, 112).

The political management of the Central Headquaters of the partisan movement performed the party-political work in guerrilla groups, constantly stuffed propaganda materials, hardware behind enemy lines, sent propagandists, journalists, typists and printers, while the supply of arms was very limited.

In June 1942 to explore the experience of advocacy of all units in the structure of the Main Political Directorate of the Red Army, military-political propaganda Council was created, whose task was to scientifically generalize study of scientific political propaganda and on this basis identify ways and means to increase its efficiency.

On July $4^{\text {th }}$, 1942 the Council of the military-political propaganda legislated directive, which contained instructions for managing work on a specific materials and its application differentiation related to the specific characteristics of the existence of enemy units and formations. To firmly root the idea of inevitable military defeat of Nazi Germany and its allies in soldiers minds, advocates emphasized the growing strength of the Soviet Army, the intensity of the anti-Hitler coalition and boundless faith in the victory of the people of the Red Army (Волковский, 2003, 393).

The Soviet leaders made a big bet on partisan advocacy. It was due to some reasons: firstly, the partisans were more affordable to settlements that were already contoled by the Nazis; secondly, part of the guerrillas could move relatively freely along the occupied territories, introducing themselves as residents of this or that settlement. It was almost the only opportunity for the Soviet leaders to influence the local people.

For the German command guerrilla movement and the movement of resistance to Soviet territory was completely unexpected. German leaders have had to study forms of guerrilla struggle, its character already during the war.

The information space played a significant role in the activities of guerrilla units on the occupied territories, which was formed directly by the USSR government, the was aimed to influence the minds of the population on the occupied areas by German fascists. 
Partisan movement for the Soviet Union, especially for the Russian people, was not a new phenomenon. It is known that in the USSR in 1920-30s a lot of work was carried out to prepare guerrilla warfare in case of a possible attack of the enemy. Hundreds of partisans of civil war were specially trained, sabotage agents developed special emphasis in case the guerrillas could make them on their own from scrap materials behind the enemy lines. But before the beginning of World War II major trained guerrillas were repressed. No one else was involved in the development of subversive technology, even the establishment of such technology was not ever raised (Салата, 2007, 71).

The formation of the guerrilla movement in this war was not provided in advance. The issue before the war was not studied at all. Soviet doctrine, as mentioned above, claimed that in case of aggression of the enemy the Soviet army could strike crushing retaliation and the enemy would be defeated yet on its territory. In 1939 this doctrine was focused not only by all the combat strength of the Red Army, but by the population of the USSR.

Only the Soviet-Finnish War, which ended in shame for the Soviet Union and significant losses proved that the use of subterranean subversive and intelligence activities and the creation of special units that would use guerrilla warfare tactics were necessary.

In fact, not only the leaders, but also the Soviet people were not prepared to conduct guerrilla warfare. Timothy Strokach words prove this fact (who was appointed a head of the Ukrainian Partisan Movement Headquarters in June 1942): "Our people morally was not prepared for possible defeat at the front, for a possible hard war, for a possible hard clandestine subversive activities in the enemy lines, which require special training" (Безсмертя. Книга Пам'яті України. 1941-1945, 2000, 222).

But despite the lack of specific experience, before November 1941 the guerrilla movement spread almost along the entire territory of Ukraine, which was occupied by German fascist invaders. The government faced the task tocontrol the activities of guerrilla units and vector it to the support of the Red Army.

With the assistance of the Information Office, headed by Lavrentiy Beria, the occupied territories, with guerrilla groups, particularly in Ukraine, in July 1941 the information space started its formation. Its main objective was to inform the partisans with the news from the front and carry out propaganda campaign aimed at "unconscious" citizens who fell into guerrilla groups in different conditions.

With the assistance of the agency, there were developed a number of measures and mechanisms that ensure the creation of the necessary information field. 
One of the most powerful tools were newspapers and radio. Thus, to provide the necessary information, the locations with the partisans were dumped a large number of newspapers from the aircraft which were published in the rear. Among them: "Partizan", "Red Partisans", "Bolshevik" and others (Центральний державний архів громадських об’єднань України, фонд 1, 40).

Ukraine party management developed measures that helped to spread the necessary information among the guerrillas and the people, who remained on the occupied lands. They included:

1) "For Soviet Ukraine" newspaper was planned to be published and droped behind enemy lines in circulation of 100 thousand copies. In addition, till 10.11.2014 such newspapers as "Communist" and "Bloshevik" had to be published behind the enemy lines;

2) extra 28 mobile printers ("F" -2 ; comrade. "K" -2 , comrade. "C2 - 2, comrade. "P" - 1, comrade. "L" - 2; comrade. "B" - 1, comrade. "B" - 1) were delivered for pulications of newspapers, postcards and leaflets by Sovinformbureau till December $1^{\text {st }} 1942$. Plus extra 22 printers till January $1^{\text {st }}$ 1943;

3) to deliver 30 radio starions till the end of the year;

4) to drop off the aircrafts 100 libraries to the guerrilla groups;

5) Increase the publication of leaflets, in appeal to the Ukrainian population. In November-December, it was planned to publish least 45 titles, including 10 illustrated. Most of the cards were spread among partisan groups, having created a network of agents to the distribution of newspapers and leaflets among the population. Use maximum capabilities to supply printed materials to the Right Bank regions of Ukraine;

6) to organize day-time radio broadcastings subterratean and partisan newspapers published behind enemy lines, and also fo guerrilla groups;

7) to publish a series of pamphlets about the struggle of the Red Army and the guerrillas and distribute them among guerrilla groups;

8) to issue a series of small essays about life and work of the Soviet people in the cities of Moscow, Leningrad, Tula, Kalinin, Kuibyshev, Saratov and others (Центральний державний архів громадських об'єднань України, фонд 1, 47-48).

Chief Political Department of the Red Army paid particular attention to leaflets distribution: during June 1941 - November 1942 the Department of Propaganda of the Central Committee of the CP (B) U Komsomol Central Committee and the Political Administration of South and South-Western Fronts have printed such publications for the population of Ukraine on the occupied territories: 
- "Communist" newspaper - 155 issues of total circulation 1340 thousand copies;

- "Communist" leaflet-newspaper - 535 thousand copies;

- "Soviet Ukraine" newspaper - 185 issues of 435 thousand copies;

- "Soviet Ukraine" leaflet-newspaper - 120 thousand copies;

- "For Soviet Ukraine" newspaper for guerilas - 141 issues of circulation of 23 thousand copies. Totaly delivered around 25 thousand copies (Центральний державний архів громадських об'єднань України, фонд 1, 41).

The management was worried about leaflets supply to the occupied areas of Ukraine, as they made it clear about what was really happening on the fronts and disclosed the policy of German occupation government on Ukrainian lands. The articles revealed the true plans of the enemy, its cunning plans and the criminal actions of the German administration. Most of the leaflets were left by the Red Army soldiers while retrograding. There were 25 issues in total of total circulation of more than 26100 thousand copies. Among them - 10 issues of illustrated leaflets, they were more attractive to the population of the occupied territories. Their circulation was 10000 thousand copies. A considerable number of leaflets were dropped from airplanes - 140 issues of total circulation of 251616500 copies (Центральний державний архів громадських об'єднань України, фонд 1, 42).

The main Political Directorate of the Red Armym the leaders of guerrilla groups organized systematic permanent notification of the population on the occupied regions of Ukraine about the domestic and international position of the USSR; spoke about active and productive work of Soviet citizens in the rear, spread the Nazi propaganda, printed articles, wrote correspondence and other materials which later spread in the rear of the German invaders (Центральний державний архів громадських об'єднань України, фонд 1,26). There were various leaflets' headlines: the situation at the front, Nazi atrocities, appeal to different segments of the population, exposing traitors etc.

Thus, the Soviet government has made every effort to control mood and behavior of the population, especially on the occupied territories. Newspapers and leaflets had become a necessary means of maintaining information space, which was formed in those regions with the help of the developed countries and the leaders of the Communist Party of methods and technologies.

The proof of such policy of the Government is the memories of O. Saburov, the "Hercules" partisan unit Commissioner: "In the first weeks of the war partisans had only small homemade receivers. With the help of them, partisans listened to "Latest news from Moscow", then copied by hand and distributed among the population". 
The proof if the management and contents of radio programs, which were in air for guerrillas and the population on the occupied territories, was radio inquiry about managing radio programs for partisan newspapers, propagandists and agitators of guerrilla groups of Ukraine. The document stated that radio programs contained:

- Materials, which described the situation at the front. Special messages of Soviet Informbureau, data about losses of Nazi forces; the morale state of the German army and armies of German allies;

- Materials, which characterized the situation in the Soviet rear: increase the production of weapons, ammunition, food (factories, farms); Soviet people's patriotic movement; unity of the Soviet front and rear;

- Information about Ukrainian guerrillas military actions and other occupied territories;

- A commented information from abroad. Chronicles of the anti-Nazi struggle of the peoples of the occupied European countries by Nazi Germany;

- Articles which reveal the lies of Nazi propaganda, leaflets for publication in partisan detachments (Центральний державний архів громадських об'єднань України, фонд 1, 11).

There was also founded "Guerrilla truth" newspaper, which included printed materials, broadcasted by the Soviet Informbureau which were later distributed among the partisan units and people on the occupied territories (Центральний державний архів громадських об’єднань України, фонд 1, 7-9).

For example, S. Kovpak union raided from the Bryansk forests to the RightBank of Ukraine. Going in the raid, the guerrillas preparing a huge number of leaflets with pictures, which were in their possession (Центральний державний архів громадських об'єднань України, фонд 1, 13).

Commissioners of guerrilla groups and political instructors often conducted interviewsby their own with local people. Sometimes partisans hung leaflets in villages conquered by the Nazis directly on their windows for ads. The invaders did quickly notice that it was not their newspapers (Центральний державний архів громадських об’єднань України, фонд 1, 15-16). These "tricks" of the guerrillas made it possible to disseminate the information in the most remote parts of the occupied territory.

One of the commissioners of guerrilla group proved that they often spread information that refuted the provocative materials in response to a provocation of German newspaperd.

A special theme was developed in all newspapers which were published for the guerrillas. For example, front-line journalist Georgy Rzhanov said: "Guerrillas listened to Moscow. They have known about news of intensified guerrilla movement throughout Ukraine from messages of the Soviet 
Informbureau, about the establishment of the Central Headquaters of the partisan movement at the Supreme Command, which would conduct this movement. Almost every night guerrillas listened to special programs created for them and the population of the occupied territories" (Салата, 2007, 74).

In the first place the Soviet Informbureau issued latest messages. Anchormen announced morning and evening live arches to partisans. Then, there were messages "The last time". Sometimes it was possible to broadcast the material which could wind up the Nazi propaganda.

Along with the official reports of the Soviet Informbureau they tried to give the best information about the guerrillas, which appeared in the national press and in which their activities were positively characterized by population on temporarily occupied territories.

Broadcasting all necessary information to partisan newspapers fully justified itself (Радио в дни войны, 1975, 52).

At the beginning of the war, with the assistance of guerrilla groups there were published 270 subterranean books! The usual place of publishing office: house, vehicle or just a shelter in forest, turning into a kind of club - cell of concentration and distribution of information. Farmers and the youth from the surrounded villages came with the guerrillas to read the latest reports from the war fronts (Радио в дни войны, 1975, 53).

In addition, leaflets were replicated in many partisan groups. For example, according to incomplete data, in S. Kovpak group during the second half of 1942 ther were published 900 thousand copies, and in groups A.Saburov and A. Fedorov - 800 thousand and 400 thousand copies (Центральний державний архів громадських об'єднань України, фонд 1, 28-29).

Thus, we see that one of the priorities in the activities of the guerrillas was campaigning and advocacy on temporarily occupied territories. It included: preparation of wall newspaper, leaflets; dissemination of information broadcast by the Soviet Information Bureau; hanging leaflets, slogans, appeals on the trees in the forest. They criticized the false reports of Nazi propaganda, and others (Центральний державний архів громадських об'єднань України, фонд 1, 36).

Political control was given instructions for the organization of "Soviet Ukraine" radio station to the population of the occupied territories of Ukraine and the guerrillas who operated deep behind enemy lines. In June 1941 the Political Berau of the Communist Party (Bolshevik) of Ukraine legislated resolution about the format and frequency of issued "Communist" and "Soviet Ukraine" papers. Subsequently there was legislated about the format and frequency of such publications as "Komsomolets Ukraine", "Stalin tribe" and others (Центральний державний архів громадських об’єднань України, фонд 1, 28). 
In order to strengthen the activities of Soviet agitators and propagandists, the circulation of "People's agitators" magazine was increased from 120 thousand copies to 150 thousands. In this magazine soviet propagandists could find detailed instructions of the methods and techniques of propaganda and informational influence on masses in general and on individual in particular (Центральний державний архів громадських об’єднань України, фонд 1, 2).

There were systematically organized special programs which had the task to convey the experience of guerrilla warfare to some other units (Центральний державний архів громадських об'єднань України, фонд 1, 17).

A powerful tool for partisan political education and increase of their responsibility to the people was military oath regarding hard work on strengthening discipline and organization in groups and education of hatred for the invaders (Центральний державний архів громадських об'єднань України, фонд 4620, 179).

Various forms of verbal propaganda were widely used. According to numerous memoirs of participants of guerrilla warfare, the forms of work were sufficiently well-known: there were mass meetings in the liberated villages, conversations of partisan agitators, intermittent rallies and meetings during combat conversion unit.

In these cases guerilla units used forms of political work, customary for Soviet people, such as rallies, demonstrations and even military parades in the days of revolutionary holidays. For example, the resonant response took place in Dubovichy village during parade on February $23^{\text {rd }} 1942$ by Putivly combined detachment (Центральний державний архів громадських об'єднань України, фонд 4620, 180-181). A large number of local residents took part in parade. This action demonstrated support to the Soviet regime.

According to the decree of Defense Commissar of the USSR dared September $5^{\text {th }} 1942$ "About the tasks of the guerrilla movement", to the decree of CPSU (b) dated October $2^{\text {nd }} 1942$ and to the decree of the State Defense Committee of the USSR dated November $11^{\text {th }} 1942$, Partisan groups of A.F. Fedorov, A. Saburov, S.A. Kovpak, K.S. Melnik etc. were spread published newspapers and leaflets, which were distributed among local people. O. Saburova squad had published more than 102 titles of newspapers, leaflets, newsletters by total circulation of 156,183 copies (Центральний державний архів громадських об’єднань України, фонд 4620, 18-23).

During 1942 CC CP (B) U and political department of the Southern and Southwestern Fronts have delivered 222 million copies of different publishings behind the enemy lines in total. Most of the printed materials had little impact (Ивлев, 1988, 58).

Only in January 1943 they have sent 13 kinds of leaflets to the occupied territories of Ukraine. 
During the whole war the were distributed about 400 million newspapers, leaflets, appeals and other printed materials on the territory of Ukraine.

Equally active was publishing in Crimea, where the information space was in quite tough conditions. Here, since May 1942 to February 1943 there were published 35 issues of the newspaper "Red Crimea" total circulation of 735 copies. They were sent to the rear of the enemy (Ивлев, 1988, 61).

For the manufacture and distribution of printed propaganda directly into the units there were delivered 56 portable printers (including 21 body printers). During short-term typing courses there were taught 37 people (later 8 people were sent in to the front). 350 libraries, mobile cinema unit (which could serve more than 10 thousand people) were packaged and shipped to guerrilla.

Since November 1942 till April 1943103 issues of leaflets have been published in Ukrainian. Total circulation was about 8100 thousand copies. 1980 thousand copies of magazines and 300 thousand of brochures ("Communist", "Soviet Ukraine", "Sovetskaya Ukraina", "For Soviet Ukraine”) were also published (Центральний державний архів громадських об'єднань України, фонд 4620, 24).

To distribute the necessary information, the Central Committee of the CPSU (b) outlined such tusks tp the leaders of guerrilla groups:

1) to deliver 50 portable printers to guerrilla groups;

2) to organize broadcasting the information for the newspapers, flyers and other printed publications on the temporarily occupied Soviet lands through "Soviet Ukraine" and "T. Shevchenko" radio stations;

3) to increase the publication of leaflets for different social groups with a call to go to and strengthen the guerrilla fighting against the German invaders;

4) periodically to dispatch active guerilla groups for meetings, lectures and reports to partisan detachments.

To fulfill task list on the activities of Ukraine guerrilla groups, CPSU (b) requests to allocate Ukrainian Partisan Movement Headquarters:

- Weapons, ammunition, clothing, equipment, medicines and food;

- Radio of the following types: "RAO" -1 pc. "RAF" -2 pcs., "Jack" 30 pcs., "Sever" - 100 pcs., "CA-I" - 100 pcs., "RPM" - 25;

- The receiving equipment such as: "Seagull" - 5 pcs., "Hamer-Lund" 3 pcs., "A-5" -5 pcs.;

-50 pieces of portable printers (Центральний державний архів громадських об'єднань України, фонд 4620, 53-54).

As noted above, lectures, conversations and other forms of communication with the people who carried out the guerrillas played an equally important role in the information space created on the occupied territories. So, judging by reports, 
in Sumy, there were held 698 meetings, attended by 73 thousand people, organized by members of guerrilla groups. In July-August 1943 there were held 392 meetings in 104 towns, under command of A. Saburov in 104 towns, which attended more than 40 thousand people (Богатырь, 1963, 263).

In 1944 the activists of the 1st Ukrainian partisan division had more than 1600 meetings in political topics witht the residents of Rivne, Volyn and Lviv regions. Activists unions under the command of M.V. Taratuto in September 1943 - February 1944 have organized 1100 interviews. The guerrillas under command of S.O. Olesiyenko covered more than 900 settlements in 36 regions of Zhytomyr, Kamenetz-Podolsk, Rivne, Ternopil and Volyn regions (Григорович, 1983, 89).

The propaganda activities of guerrilla groups was directed not only against the Nazi army. The Ukrainian national movement was also its ideological opponent on the occupied territories. According to the famous historian J. Amstrong, Soviet partisans opposed the Ukrainian national movement, searched for information about the Ukrainian conscious, preparing various provocations, eliminated a number of Ukrainian patriots. Since 1942 each squad of Soviet partisans had a special department of the NKVD, later called "SMERSH". One of the major tasks of partisan movement in Ukraine was the disruption of life of local civilians struggle with nationalist forces that spontaneously arise during people's resistance to invaders and operated without the control of the Soviet government (Armstrong, 1964, 29-32).

Wehrmacht management faced extremely difficult tasks on the occupied territories. Its main reasin was constant counteractions of Soviet information flows. Forming the information space on the occupied territories of the USSR, the Nazi management leadership, on the one hand, had to justify and disguise the colonial policy, which was based on exploitation, hunger and mass murders, and on the other - had to stimulate the occupied areas for cooperation. German propaganda was based on anti-Semitism, and Bolshevism and on the opposition of individual nations and nationalities of the Russian people. As the Wehrmacht management paid great attention to the information during the war, enemy propaganda was well organized and the number of the invaders increased. Even despite the fact that the Soviet government also used the various campaign activities, the number of defectors during the 1943-1944 still remained high. Thus, according to the historian L. Naumov, the number of prisoners amounted to 994 thousand people, and those, who was considered deserters - 376 thousand people. Overall, he estimated, 1.8 million people returned from captivity (among them wounded and injured) (Наумов, 1996, 429-435). As to the population of the temporary occupied territories, the German information space had almost no support. 
Hunger, exploitation, deportation, persecution and mass extermination of Jews and representatives of other nations left no illusions about the future structure of social life. People were increasingly convinced that to survive in combat was more real than to serve for the Wehrmacht

Wermacht leaders believed that people's emotional state played and important role in the dissemination of any information, which finally let to the formation of commitment to the new government.

According to psychologists, an emotional injection was necessary to maintain a permanent human interest to propaganda, and to make information more easy to remember, to penetrate into very consciousness. The het-up person carries out rash act much easier. This is what mainly pushed for the leaders of the Third Reich. In addition, very emotional excitement alters human behavior, even daily one. As a rule, a person can feel the body mobilizing, the surge of power. These forces were successfully used by politicians of both totalitarian states, skillfully guiding them to the proper direction (Гогун, 2004, 25).

The Soviet government stuggled to create powerful information space on the occupied territories. Although official propaganda was not fully trusted by the population, true-to-life stories seemed to be told by farmers from the occupied areas. They were sent to the villages, not yet occupied by Hitler, to tell stories about their life during the Nazi occupation, so they could call on farmers to greater diligence during harvesting.

The German army, as already noted, measured its success or failure by the number of defectors. Reports of many agencies were filled with figures showing the growth of production, an increase in personnel, materials, vehicles, media etc. At the same time, Soviet propaganda industry did not provide a sufficient number of equipment, materials and personnel. For example, only reporters from "Red Star" newspaper and "News" governmental newspaper possessed aircrafts. The Central Committee did not inform TASS about editors' mistakes. TASS device was extremely ineffective. Sometimes it took months for the device to make decisions, but not minutes as it had to be (Советская пропаганда в годы Великой Отечественной войны, 2007, 32).

In total, in November 1943 - January 1944 in Donbas, there were published 34 newspapers, which attracted best propaganda promoters to work on the publishing office. Particular attention was paid to the materials that reflected the political topicality. Local departments of the Communist Party carried out an active mobilization of party organizations, communists and Komsomol members at the elimination of Nazi propaganda (Державний архів Вінницької області, фонд Р-6022. 28). 
Thus, in terms of World War II, there was formed information space on the whole territory occupied by the German army - Reich Commissariat "Ukraine" and in the area of military administration and throughout the Soviet Union, by the Communist party leadres and the government with the help of specially developed methods. Its main task was to keep the faith of the population in communist ideas, by any plea unite the people to fight against the Nazi invaders, destroy-insurrectional subterranean formation, which, although opposed the invaders, but constituted a great danger to the Soviet regime.

A considerable information flow was aimed at guerrillas and people on the occupied territories. Soviet government are the Communist Party managed to develop strong mechanisms and means of information dissemination and its transformation into information space. Guerrilla groups were mainly used more as a means to spread necessary information to the population of the occupied territories and as a tool to combat enemy forces and the regime and all entities whose ideas contradicted the current communist regime. Despite a great amount of losses, the results of the war shows, that these methods were very effective.

\section{REFERENCES}

1. Ленин В.И. 1967. С чего начать? Полн. собр. соч. Т. 5. Москва : Издательство политической литературы.

2. Сталін Й. 1952. Про Велику Вітчизняну війну Радянського Союзу. Москва : Издательство политической литературы.

3. Центральний державний архів громадських об'єднань України. Фонд 1 - Центральний Комітет Комуністичної партії (більшовиків) України. Оп. 70. Спр. 32.

4. Король В.Ю. 2002. Трагедія військовополонених на окупованій території України в 1941-1944 роках. Киъв: Видавничий центр «Академія».

5. Панарин И. Н. 2006. Информационная война и геополитика. Москва : Издательство "Поколение”,

6. Советская пропаганда в годы Великой Отечественной войны: “коммуникация убеждения" и мобилизационные механизмы 2007. Авторы-составители А.Я. Лившин, И.Б. Орлов. Москва : Российская политическая энциклопедия.

7. Русский архив: Великая Отечественная 1997, за редакцией Золотарева В.А. Т. 20 (9): Партизанское движение в годы Великой Отечественной войны 1941-1945 гг.: документы и материалы. Москва : Teppa. 
8. Почепцов Г.Г. 1998. Информацтонные войны - основы военнокоммуникативных исследований. Киев: «Славянский университет».

9. Коммунистическая партия в Великой Отечественной войне (июнь 1941-1945 гг.): Документы и материалы. 1970. Москва : Политиздат.

10. Центральний державний архів громадських об'єднань України. Фонд 1 - Центральний Комітет Комуністичної партії (більшовиків) України. Оп. 70. Спр. 989.

11. Русский архив: Великая Отечественная, за редакцией Золотарева В.А. 1997. Т. 13 (2-2): Приказы Народного комиссара обороны СССР. 22 июня 1941 г. 1942 г. Москва : Терра.

12. КПСС в резолюциях и решениях съездов, конференций и пленумов ЦК (1898-1986). 1985. Издание 9-е. дополненое Москва : Политиздат, Т. 7.

13. Никулина Н.Ю., Сорока 3.Н. 1999. Советское Информационное Бюро в годы Великой Отечественной войны. Проблемы источниковедения и историографии. Калининград: Калининградский государственный университет.

14. Советское информационное бюро (Совинформбюро). Риановости: Доступ 2 мая 2014 http://ria.ru/spravka/20140624/1012873157.html.

15. Салата О.О. 2009. Радянське Інформаційне бюро як механізм управління інформаційними потоками в умовах Великої Вітчизняної війни. Наукові записки Вінницького державного педагогічного університету ім. Коцюбинського. Вінниця. Видавництво Вінницького державного педагогічного університету ім. Коцюбинського. № XIV.

16. Советская военная энциклопедия 1979. Под ред. Гречко А.А. Москва : Воениздат.

17. Сообщения Советского Информбюро. 1944-1945. В 8 т. Москва : Совинформбюро. Т. 1.

18. Русский архив: Великая Отечественная. 1997. Под редакцией В. А. Золотарева. Т. 20 (9): Партизанское движение в годы Великой Отечественной войны 1941-1945 гг.: документы и материалы. Москва : Teppa.

19. Меленберг А. 2005. Взорваны и забыты. По материалам сайта “Новая газета" Доступ 11 июня 2015: http://2005.novayagazeta.ru/ nomer/2005/16n/n16n-s23.shtml.

20. Великая Отечественная война 1941-1945: Энциклопедия 1985. Под редакцией М.М. Козлова. Москва : Советская энциклопедия,

21. Мельтюхов М.И. 1991. 22 июня 1941 г.: цифры свидетельствуют. История СССР. № 3.

22. 1941-1945. Публицистика и очерки военных лет. 1982. Т. 1-2. Москва : АПН. Т. 1. 
23. В комиссии Политбюро ЦК КПСС. 1989. Известия ЦК КПСС. № 12 .

24. Ржанов Г. 1975. Партизаны слушали Москву. Радио в дни войны. Москва : Политиздат.

25. Центральний державний архів громадських об’єднань України. Фонд 1 Центральний Комітет Комуністичної партії (більшовиків) України. Оп. 70. Спр. 57.

26. Бурцев М.И. 1981. Прозрение. Москва : Воениздат.

27. Чайковський А.С. 1990. За нами Большая земля: Помощь советского тыла в организации народной борьби против фашистских захватчиков на временно оккупированных территориях Украины, 1941-1944 гг. Київ : Вища школа.

28. Советская пропаганда в годы Великой Отечественной войны: «коммуникация убеждения» и мобилизационные механизмы. 2007. Автори и составители Лившин А.Я., Орлов И.Б. Москва: Российская политическая энциклопедия.

29. Волковский Н.Л. 2003. История информационных войн. В 2 ч. Ч. 2. Санкт-Петербург: ООО Издательство «Полигон».

30. Центральний державний архів громадських об’єднань України. Фонд 1 - Центральний Комітет Комуністичної партії (більшовиків) України. Оп. 19. Спр. 5.

31. Салата О.О. 2007. Роль партизанських з'єднань у створенні інформаційного простору на окупованих землях України у 1941-1944 роках. «Університет». Київ : Видавництво Київського Славістичного університету. № 2.

32. Безсмертя. Книга Пам’яті України. 1941-1945 2000. За редакцією I.O. Герасимова, І.T. Муковського, П.П. Панченка. Київ : Пошукововидавниче агенство «Книга Пам’яті України».

33. Центральний державний архів громадських об'єднань України. Фонд 1 Центральний Комітет Комуністичної партії (більшовиків) України. Оп. 70. Спр. 12.

34. Центральний державний архів громадських об'єднань України. Фонд 1. Центральний Комітет Комуністичної партії (більшовиків) України. Оп. 19. Спр. 2.

35. Центральний державний архів громадських об'єднань України. Фонд 1. Центральний Комітет Комуністичної партії (більшовиків) України. Оп. 70. Спр. 19.

36. Центральний державний архів громадських об'єднань України. Фонд 1. Центральний Комітет Комуністичної партії (більшовиків) України. Оп. 70. Спр. 199. 
37. Радио в дни войны 1975. По редакции М.С. Глейзер и Н.М. Потапов. Москва : Искусство.

38. Центральний державний архів громадських об'єднань України. Фонд 1 - Центральний Комітет Комуністичної партії (більшовиків) України. Оп. 70. Спр. 989.

39. Центральний державний архів громадських об’єднань України. Фонд 1 Центральний Комітет Комуністичної партії (більшовиків) України. Оп. 70. Спр. 5.

40. Центральний державний архів громадських об'єднань України. Фонд 1 Центральний Комітет Комуністичної партії (більшовиків) України. Оп. 6. Спр. 649.

41. Центральний державний архів громадських об'єднань України. Фонд 1 Центральний Комітет Комуністичної партії (більшовиків) України. Оп. 6. Спр. 678.

42. Центральний державний архів громадських об'єднань України. Фонд. 4620 Колекція документів 3 історії Великої Вітчизняної війни. Оп. 3. Спр. 128.

43. Центральний державний архів громадських об'єднань України. Фонд. 4620 Колекція документів 3 історії Великої Вітчизняної війни. Оп. 3. Спр. 100.

44. Ивлев И.А. 1988. Оружие контрпропаганды, Советская пропаганда среди населения оккупированной территории СССР. Сборник материалов. Москва : Мысль.

45. Богатырь 3.А. 1963. В тылу врага (Боевая деятельность соединения партизанских отрядов под командованием Героя Советского Союза А.Н. Сабурова). Москва : Соцэкгиз,

46. Григорович Д.Ф. 1983. Идейно-политическая деятельность Компартии Украины в годы Великой Отечественной войны. Киев: Политиздат Украины.

47. Armstrong J. A. 1964. (Ed.) Soviet Partisans in World War II. Мадісон.

48. Наумов Л. 1996. Советский Союз во Второй мировой войне: Критический очерк советской историографии войны. Русское издание Александра Прегер. Los Angeles,

49. Гогун А. Черный PR Адольфа Гитлера: Документы и материалы. Москва : Эксмо, Яуза, 2004.

50. Державний архів Вінницької області. Фонд Р-6022. Колекція свідчень, спогадів та інших документів колишніх в'язнів гетто, концентраційних та робочих таборів, а також громадян, примусово вигнаних до Німеччини. Оп. 2. Спр. 17. 


\section{SECTION 2.3. \\ TECHNOLOGIES AND METHODS FOR IMPLEMENTING THE INFORMATION POLICY OF BOTH COUNTRIES IN THE TERRITORY OF UKRAINE}

The 20-th century was the period when informational propaganda was actively used in political, economic and military spheres. During this period the totalitarian states sought to create a single common information space controlled by the country's leadership.

Concepts such as "information war", "information aggression", "information security" as it was known originated during World War II and the Great Patriotic War. There was a close connection of mass media with conflict situations. It should be noted that in armed conflicts a fight on an information field seemed not to be less important than directly military operations.

In our opinion the change in the information and military sphere took place just on the eve of World War II. The German military command has repeatedly stated that the cause of the defeat was not only the courage of the Soviet soldiers and the population but also influence on the consciousness of the mass media of both states as the U.S.S.R. and Germany. Then the existence of "information and psychological ensuring fighting" was recognized necessary to form through media public opinion that any military operations found support among its population. Methods practically do not differ from usual signs "public relations". It is known to be the creation of quantitative and qualitative own point of view of advantage in media and the introduction of steady associations, schemes, myths that meet the interests of information campaign organizer. It was also applied by the Nazi government of Germany already during World War II and in occupied territories.

In the U.S.S.R. and Germany there were qualified personnel in the field of propaganda. It should be noted also, as that increased the experience far before coming to power. For example, political circles of the USA noted that Bolsheviks of 1918 carried out a great influence on the population of the Russian Empire. So, the Ukrainian army which totaled one million people under the influence of Bolshevist propaganda was demobilized within two months (Камінський, Дашкевич, 1998, 121). The Russian political scientist Mr. Pocheptsov explains the fact that "the slogans of Bolsheviks reflected the 
interests of fighters of the Ukrainian army which consisted of vast majority of ordinary peasants. They wanted to work on earth in peaceful conditions" (Почепцов, 2001, 66).

In the military-political concept of Hitler's Germany attention was paid the creation of information space not only in their own country but also in Europe and the territories of other countries occupied by the German army that

Thus, so that political concept, military strategy and tactics developed by the Hitler's leadership of Germany would be realized it was necessary to exert a powerful information pressure on the German population space, first of all, and then the population of the territories occupied by German fascist army.

How the Nazi leadership of Germany understood the role of information and information space? It is possible to say with confidence. that they understood. Experience of flippant attitude information and propaganda led Germany to defeat in World War I. Therefore on the eve of World War II Hitler and his entourage paid much attention to the formation of propaganda bodies and information influence across the vertical of military and political leadership. It is proved by documents that the financial oligarchy of Germany financed the propaganda campaigns of Nazis.

In the 20-30s of the 20-th century the international community, in particular, Great Britain and the USA, already owned methods and technologies of impact on the consciousness of the population and its behavior. They created own information space using advanced communication technologies of that time.

Today, as well as seventy-five years ago, information space is, first of all, the sum of difficult information technologies which are a basis and the defining component of an industrial and economic complex of transnational communities which influence formation of world outlook processes in society (Shreyder, "the theory of communications") (Шрейдер, Шаров, 1982, 71).

There are general models of influence within propaganda and counterpropaganda. They represent a modification to an information field to obtain results of their change in real living floor space. Such information field is used for the solution of social, political, economic, military tasks. Information space has particular importance during the war. For example, the fascist leadership of Germany during 1941-1944 understood the role of information which impacted on the consciousness of the population and and their willingness to fight.

From the very beginning of the political activities A., Hitler and the leadership of fascist Germany paid much attention to information impact on the mentality of the person. Having analyzed consequences of World War I they concluded that information, propaganda weighs not a less powerful in comparison with 
well-armed army. Having come to power for the first time Nazis applied information impact on the population of other countries. At first, it influenced the population of Germany, then the European countries. A powerful information, and psychological influence laid down on the population of occupied territories of the USSR. Information influence was carried out by various methods. Information extended through news agencies, radio, including also that were located abroad through the German correspondents working in the different countries through foreign newspapers; by holding exhibitions in Germany and abroad; in the course of implementation of cultural exchange with the friendly countries in science, art, sport. (Панарин, 2006, 156).

A. Hitler noted that in the researches concerning political events he was always interested in propaganda activity more. “... To what extreme results propaganda can bring, it is correctly used, it was necessary to wish passionately only during the war of it. Unfortunately, everything needed to be studied in other directions as results of the activity of politicians were very "modest". It is necessary to refuse completely an old education system for the German soldiers and to deal more persistently with propaganda issues" (Hitler, 1953, 141). These words of Hitler demonstrate that he understood the need to use a propaganda, moreover. He sought to change an education system and education of Germany including military education to create such information space which would direct the activity of all the population of Germany and army to a victory.

Hitler considered that propaganda had to be the best means to influence people. "Propaganda - the fight tool, and in hands of the person who well knows this business, - the most terrible weapon. The propaganda has to be turned to masses. The art of propaganda is in forcing people to believe that this or that fact exists. The art of propaganda is to understand the feelings of broad masses. National feeling simple and monotonous. The people speak yes or no. Truth or lie! The people argue rectilinearly. The susceptibility of masses is very limited, the circle of her understanding is narrow, but the forgetfulness is very high" (Макаревич, 1993, 63).

For that time technologies of information space being formed on the ideological principles not only used by the Hitler's government. The Soviet Union where the ideology and mechanisms of its introduction were extremely developed was the most powerful in this regard. The methods and mechanisms were developed by the government of the Communist Party which controlled information flow both in the USSR and beyond its limits made society undoubtedly closed.

In considering an arsenal of means and mechanisms of information space and concrete methods of impact on public consciousness we could analyze the 
basis of method's transition from simple and primitive forms to more difficult and graceful ones.

The method of psychological impact on the population of occupied territories, guerrillas, fighters and officers of the Red Army was one of the mechanisms which played an extremely important role in the formation of information space.

As a famous Russian political scientist V. Krysko thinks "the social systems of government are carried out through providing information and psychological impact on the object" (Крысько, 1999, 121).

Psychological influence is a way to influence on people (on certain individuals and groups). It is directed to change of ideological and psychological structures of their consciousness and subconsciousness, the transformation of emotional states, stimulation of certain types of behavior with the use of various ways of the obvious and hidden psychological coercion. Complex using of various ways of the hidden psychological compulsion of people in the form of the system of psychological operations, various propaganda campaigns is considered to be widespread means of political struggle, in particular, during the war (Прокофьев, 1999, 97-99).

During active fights and occupation of a part of the territory of the USSR psychological influence seemed to be existed by various methods and the main means wholly. They affected consciousness and subconsciousness of the population. Firstly, there were actually psychological methods as belief, suggestion, informing, encouragement, coercion, punishment, example method. Secondly, psychological impact was carried out with attraction of military means. Thirdly, the adverse psychological climate among the population of occupied territories which undermined the credibility of the enemy. Such as special forms of psychological influence were used: verbal, publishing, graphic, broadcasting forms.

So, at once from the beginning of the war against the USSR the Supreme Command of Wehrmacht issued "The Directive for Front Propagandists". In it it was emphasized that "in planning propaganda actions on the enemy it is necessary to define accurately what purpose of propaganda campaigns will be; a circle of people to perform these actions; place and area of the forthcoming actions; main methods of influence and main theses; technical means of distribution of information materials; optimum time of holding propaganda campaigns. In the Directive the basic principles of propaganda impact on the enemy were represented:

1. "It is not necessary to use difficult, tangled, artificially constructed designs. The more simply, more clearly, contents, higher its efficiency.

2. The person naturally is an emotional subject, therefore, it is much more effective to address her feelings. 
3. Propaganda's texts have to be logically thought over but they are not necessarily logically stated.

4. Repetition is an important mechanism of propaganda. Successful propaganda is necessary to adhere to a thesis until conditions of a psychological situation change.

5. It is very important to make use of already existing experience for an increase in efficiency of front propaganda" (Крысько, 1999, 125-126).

As far as the principles of information propaganda in the USSR there were ideological and political restrictions to use information space.

It was the prerogative of the Soviet government. It was brightly shown in information processes that took place in the Soviet society. That's no doubt that there was the characteristic phenomenon for any totalitarian political regime of the 20-th century.

Without seeking to absolutize the value of information control in the formation of totalitarianism we will note that the great influence on its formation was made by various factors Including direct state violence, traditions of the Russian statehood, etc. However, information monopoly attempts to establish control over processes that proceeded in society. And this fact happened to have played a significant role in the tragic period of 1941-1944 in the history of the U.S.S.A.

According to plans of A. Rosenberg who sought to use the population of occupied territories of the USSR, in particular of Ukraine in fight against Bolshevist Russia, there was put a question to create the information space before the Ministry of National Education and Propaganda, the Ministry of East Occupied Territories and Head Department of Imperial Safety of Germany.

It's important to study the main directions defining the information space of Hitler's Germany in occupied territories of the Ukrainian SSR and mechanisms and methods applied the government of the Reich to the distribution of the power.

On occupied territories the Department of Military Propaganda of Wehrmacht which coordinated the main propaganda strategy with Goebbels dealt with problems of military propaganda. The ministry of national education and propaganda became the largest and most influential authority authorized to control all other ministries.

At the headquarters of the Supreme main command of Wehrmacht in April 1939, the Department of Propaganda was created. In its structure there were special military units as propaganda companies. According to Instruction No. 51/39 to their competence, the solution of the following tasks entered: conducting propaganda among the German population and the military 
personnel, conducting propaganda in a front-line zone and among troops of the opponent. By the beginning of World War II, the Wehrmacht already had at the order 14 companies of propaganda (Панарин, 2006, 157).

Propaganda companies were staffed with persons who had to own equally well as journalistic (literary, radio - photo or cinema) skills, and any military weapon. The last circumstance was an especially a great value when publicizing actions of pilots, tankmen, seamen of torpedo boats, etc. As, for example, the crew of the warplane was not able to afford the luxury to take aboard any superfluous the person who would be only the observer of events which took place. But at the same time, it was not necessary to imagine a business in such a way that companies of propaganda worked only in shooting and other divisions. Each company of propaganda was applied to the whole army. The military personnel of these companies acted individually or as a part of compact groups. They were located far from other direct employees on service.

Companies of propaganda were designed to serve not only mass media of the Reich but also "to carry on propaganda directly in parts and connections of Wehrmacht, to provide psychological processing of troops and the population of the opponent..." (Орлов, 1985, 31).

"Till June 22, in general, there were 19 companies of propaganda (the twelfth ground forces, the fourth the Air Force, 3 companies in the fleet and 6 platoons of war correspondents in Troops of $\mathrm{CC}$ ). Besides, each of the three groups of armies ("North", "Center", "South") had besides also on a battalion of propaganda. They were engaged in the edition of newspapers, conducting radio-propaganda, display of movies..." (Жуков, 2000, 7).

After an attack of the German army on the Soviet Union also the population of occupied territories of the USSR fell within the scope of their propaganda. Such changes in the activity of companies of propaganda are explained by the fact that their divisions had amplified and became an almost independent type of military force since 1943. This authority was under the observation of the Ministry of national education and propaganda. Propaganda companies used leaflets, newspapers as a form of propaganda (Панарин, 2006, 283).

Instructions were developed by Department of the Ministry of East Occupied Territories. They determined the content of information and propaganda activity of structures of Wehrmacht in the territories of the Ukrainian SSR occupied with fascist army. they pursued the next aims: ensuring moral and psychological impact on local population by political and cultural propaganda by means of the press, broadcasting and cinema; implementation of propaganda campaigns which had to influence moods of 
the population for the benefit of the Reich and the German administration on places; information and cultural support of the troops which are in a zone of activity of propaganda structures (Дашичев, 1973, 196).

In the occupied territories of the USSR in the structure of the Ministry of the Press and Propaganda headed by the major Kranz there was created socalled "Russian committee" under the direction of the imperial Minister of Foreign Affairs Ribentrope in the summer of 1942.

Thus, in the East propaganda and the press in which there were the main mechanisms of formation of information space, organizationally were under supervision at once of several structures which were on hand directly Wehrmacht and to Rosenberg's ministry, and indirectly - to the Ministry of National Education and Propaganda and a number of other Nazi departments. In different territories the level of propaganda activity i was not identical. It, of course, could not but affect its efficiency. The propaganda of Wehrmacht differed in the greatest "irrelevance" and illegibility. The crucial importance as its products fell into hands of the population and enemy quicker than any other was attached to it. Cards and posters for distribution among the population of occupied territories were made rather skillfully and quickly. At the same time, not all soldiers of Wehrmacht supported methods that were applied by their government against civilians and it complicated a propaganda campaign. (Жуков, 2000, 8).

A total number of these troops of propaganda during the period from June 1941 to April 1942 was about 15 thousand People whereas the average contingent of "a propaganda company" made - 115 people (Орлов, 1985, 132).

Distribution of the German press, leaflets, holding small conversations among the population of occupied territories was the main objective of companies of propaganda: "The power of the Third Reich", "Only Germany will help Ukraine to get rid of Bolshevist slavery", "Work in Germany makes the Soviet person cultural" and many others.

It will be interesting to consider examples of propaganda leaflets which were distributed by members of propaganda companies in the occupied territory of Ukraine of 1941:

"Peasants and workers!

Who Adolf Hitler?

Ask about it the German soldier who exempted your homeland from Bolshevist animals!

Ask about it the German worker to whom he gave work, bread, and wellbeing again, that is all that it was deprived earlier...

Ask about it the German peasant who can leave the earth in inheritance to the son and the grandson now... And all of them will answer you: 
Adolf Hitler is the embodiment of force, power, kindness, justice..." (Гогун, 2004, 345).

Analyzing such pathos cards and appeals it should be noted that very few people from inhabitants of occupied territories trusted them. But a difficult life, especially the Ukrainians, and belief that other best living conditions could have been created a good basis for fascist propaganda.

In preparation for a propaganda campaign, special attention was paid into the training of the German agents and the foreign organizations of the National Socialist Party. So, for example, for propaganda in the Soviet Union agents from among the former Russian citizens who were for one reason or another forced to leave before the war the USSR prepared. Under the leadership of national socialists they prepared analytical materials for bodies of propaganda, defined weaknesses of the Soviet society, developed recommendations on information and psychological impacts on the staff of the Soviet Army and the population of the areas occupied by fascist army taking into account national psychological peculiarities, traditions and culture (История ВКП(б), 1938, 317).

The use of the former Soviet citizens was caused by the realization of the purpose of Wehrmacht to demoralize the Soviet Army and to give the population of occupied territories to full disappointment in the Bolshevist mode. Not only cards but also periodic material prepared for this purpose and used: books, photos, movies, put on the Soviet political figures). At the same time information of the Soviet newspapers issued in a borderland, large-circulation editions of the enterprises and the departmental periodical press appearing big circulations, broadcasts, etc. was exposed to processing. Since the end of 1940, the leadership of Hitlerite Germany begins to show great attention to the internal life of the Soviet Union, trains agents already from among the German experts for obtaining important information on the economic and political situation of the USSR (История ВКП(б) 1938, 317 - 318).

Carrying out the task, bodies of propaganda were guided developed by department of propaganda of Wehrmacht and given out in the first half of June, 1941 "By instructions on implementation of propaganda during implementation of the plan Barbarossa". "Instructions..." defined organizational, political, psychological bases of activity of bodies of propaganda and contained ideological and political installations. Among them were also such: an enemy of Germany is not the people of the Soviet Union but only "yids-Bolshevist" with the functionaries and the Communist Party; the German Wehrmacht came not as the enemy of civilians, it, on the contrary, seeks to exempt them from tyranny of Councils; each attempt of resistance will be ruthlessly suppressed; it is not allowed to propaganda to 
nominate the idea of creation of the national states (disintegration of the Soviet Union to the certain states) for the economic reasons dissolution of collective farms it is not planned yet (История ВКП(б), 1938, 317).

Information and psychological impact on the population of occupied territories from the Hitler's government were periodically weakened because the Soviet power also applied not less effective propaganda, military, police and psychological remedies.

From the very first days of the war Soviet leadership created organizational and information mechanisms that complicated the activity of the occupational guide to the introduction of own ideological and political theories and strengthened the information and ideological field which already worked at the territory of Ukraine. The information and ideological field which was created in Ukraine by Soviet leadership was used for impact on the consciousness of the population, introducing the socialist ideas and propagandizing hatred to everything the capitalist world.

By the beginning of the Great Patriotic War the ideological sphere of the USSR had already became a core of the Soviet information space being formed in the country. Methods that were applied by the government of the All-Union and Communist Party (bolshevik's) were considered by Party's leadership on places the most effective. Although many ideological campaigns looked absurd and compromised the existing way of life in public consciousness. It is interesting that such methods suppressed a considerable part of the Soviet people, estimated operations of ideologists of the Communist Party, characterized them as absolute nonsense (Цыбмал, 1995, 35).

Despite the activity and importance of the Soviet propaganda, nevertheless, a considerable part of the population understood what happened in the state and could analyze consciously events and realities of the Soviet life.

Despite of it, the traditional direct way of psychological impact on consciousness which relied on the belief of people was one of the methods used by Hitler's administration in occupied territories of Ukraine and it was turned to their mind. Rational arguments, logic were applied. This method was used by both the Hitler's administration, and the Soviets.

Let's take an example of this method in the USSR. The application of rational arguments of logic was characteristic of Marxism where the thesis "life was the starting point of an explanation defines consciousness". At the beginning of the Great Patriotic War, the country appeared before a terrible accident: danger of loss of statehood and transformation of the population into slaves. At the same time the society was driven to extreme despair by own government and its policy of collectivization, repressions against "enemies of 
the people" and Famine-Genocide. Despite of it, the leadership of the USSR and Soviet Ukraine, in particular, understood that it was necessary to fight back the enemy and not to allow occupation of the country by the fascist army. And as the major task in this context was the idea to build such information space in which everyone realized need to save the socialist homeland and its gains.

A necessary component of carrying out such explanatory work turned to the reason for people and consciousnesses was an accounting of real conditions. At the same time, it is important to understand the distribution of forces, the real interests of people to carry out the analysis. At the same time it was necessary to consider a condition of public consciousness, that was to give accurate, noticeable, clear slogans: "Our right cause! The enemy will be broken! The victory will be for us" and "All for the front, all for a victory!" and others. A characteristic example - events of civil war, we will remember Furmanov's "Mutiny": "How to take it in hand, this rebellious crowd? it is necessary to act firmly, surely as strong and without the slightest concessions, fluctuations. This the first: firmly and without being given generally. And the second not to release for one moment from under an inquisitive look all crowd, together with observing it from all directions and in all manifestations... thirdly, here that: know, then there lives the crowd: the most essential knowledge in its interests. and in them speak... Then, fourthly look on faces, all in eyes, catches at proper words, guess on movements... If did not strike the right note, business was gone... in - the last, so to speak, on separation олько two words: when no measures and means help... - I will descend from a tribune, from a barrel, from a box, all the same from what, I will descend as safely as ascended there... perishes under fists and butts, the agitation. So did that and from your death, there was an advantage" (Фурманов, 1985).

The principles of accounting of a real situation were widely used also by leaders of Nazi Germany. The characteristic example is given in the book by M.I. Burtsev "Enlightenment" devoted to propaganda fight against the fascist army in 1941-1945 Hitler then told: "We brought up youth against which the whole world, youth rough, exacting, cruel" (Бурцев, 1981, 24).

But in that time the cruelty generated another feeling. The German soldier was sentimental. He thought about the future of his family and he did not understand for what future he would have to die. The Soviet card with the image of the snow-covered field, corpses of the German soldiers became the proof of it for them, already froze, and on this background close up the child, cries; and under the drawing only three words: "Fater ist tod" "“The father is killed"). Most of the German soldiers held in hand this card as the admission 
in captivity (Кочергин, Коган, 1980, 20). As we see, this method was a very effective tool in the belief of soldiers of Wehrmacht.

In the period of the Great Patriotic War both sides paid a lot of attention to the distribution of leaflets in the back of own army and temporarily occupied territory. The Soviet leadership understood that at the front soldiers did not less need for cartridges, clothes, food, resting. They waited for information and moral support. This fact seemed to define moral of soldiers.

The maintenance of such cards and posters caused the Ukrainians to dump Bolshevist domination and to support the German army in the release of their territory. The posters and the cards, told about what merciful German soldiers to children, etc. (Немецкая пропаганда на территории СССР, 2013).

Placing differently semantic accents in several leaflets devoted to the same question both the German and Soviet propaganda managements considered psychological features of various groups of the military personnel and the civilian population of the opponent. Printing registration of a card promoted strengthening its emotional actions. Reproduction in leaflets of photos, copies of official documents increased their persuasiveness. Contents of the leaflet consisted most concisely so that it was easily perceived even at forcedly fast reading. Thanks to a small format, it was easy to be hidden, transferred, kept as the admission in captivity.

For drawing up cards and other types of propaganda by the German propaganda structures various methods and receptions were used. Rational arguments when for explanatory work the real interests of people and public consciousness, in this case, this population of occupied territories was used and his desire to live and to manage freely in the independent country was applied.

Granting selective information was the following important method which was applied by the Nazis. It was formulated by simple phrases and repeated many times. Thus, the person subconsciously absorbed this information. The card which was released in April 1943 agitated for a transition to the party of Germans and the introduction in the Russian liberation army. It was used such method when its name repeated in the leaflet of 12 times (Лисичкин, 2005, 41-43).

A large number of propaganda materials for strengthening of ideas of "a liberating mission" of the German army was given by the Ministry of National Education and Propaganda together with the Ministry of East Occupied Territories. The whole series of cards were directed to discredit the leaders of the Soviet state and the command structure of the Red Army. Among them, there were cards about Stalin and his government (Гогун, 2004, 64-65).

In the first months of the war in Kyiv, the Ukrainskoye Slovo newspaper, (later "A new Ukrainian word") which editor was K. Shteppa was issued. The newspaper had to cover all events which positively reflected the activity 94 
of the German occupying authority and "to expose" Bolshevist policy. Along with political messages and publications articles about the cultural life of Kyiv and the policy of the German authorities were published in the newspaper (Верба, 1999, 27-29).

To strengthen a negative impression about the activity of the Soviet government, the Nazis government distributed comical images. They were also in local newspapers, and on cards. So in the "Volyn magazine" there was the caricature where Bolsheviks was shown as a hungry wolf who looked up at a basket (Ukraine which lifts the German cross) (Волинь. Часопис для Волині, 1943. 2).

The caricature became one of the most widespread levers on the population of occupied territories even if at first sight the person was not engaged to see and read on the picture, over time this picture had been already renewed in the memory at the level of subconsciousness. Caricatures were in the majority of issues of any newspaper published in the occupied territory of Ukraine. The issues of the Vinnitskiye Vesti newspaper published on Vinnichchin from April to July 1941 (Вінницькі вісті, 1942, 3; Вінницькі вісті, 1942, 3; Вінницькі вісті, 1942, 4, Вінницькі вісті, 1942, 2; 4; Вінницькі вісті, 1942, 2; Вінницькі вісті, 1942, 4).

In the first months of the war of Hitler's Germany with the USSR a considerable part of the population of occupied territories of Ukraine believed that now having exempted from the Bolshevist mode they would be able to create the independent state where they would be owners on the earth. The German propagandists tried to maintain an exact balance between the absolute truth, half-truth and a lie (you should not forget that there is also "white lie") on this problem. And this balance depended on the present provision and events at the front because the population of occupied territories recognized the real policy of the fascist leadership very quickly.

In such and similar situations the German government sought to influence the local population to form his morale in the necessary direction.

Knowing how the population of Ukraine treated the process of collectivization and sought to have its plots the Hitler's leadership convinced the population of occupied territories that the fascist army had fought for a new order to change an old system, a communistic arbitrariness. There was the next slogan: bread, instead of hunger and poverty.

As an example we offer the text of one of the most popular German leaflets - as addresses to citizens of the Soviet Union, fighters and commanders of the Soviet Army, especially peasants:

"Citizens of the Soviet Union, fighters and commanders of the Red Army!" 
The German army fights for a new order, instead of an old system, a communistic arbitrariness; bread, instead of hunger and poverty.

Return of landowners-capitalists it will not be allowed. Though the war continues.

The country yards and personal plots which were still in private use of collective farmers are transferred to the full possession to peasants and will not be assessed with taxes and requisitions... (Окороков, 2007, 96).

Thus, having considered the desire of peasants, their serious condition owing to the "managing" of the Bolshevist power, the German occupational administration tried to turn the population of occupied territories on the allies in the fight against the Soviet Union.

Totally in the German leaflets, unlike the Soviet, the main focus is concentrated on the personality which is on the fact that for each person it "I" am the most important in life that she does not care about grandiose losses of the country, failures at the front. Generally the German propaganda hoped for the natural law of self-preservation, aspiration of the person to survive at any cost, to settle safely in any conditions. The Soviet power, addressing the population, fighters, and officers of the Red Army, focused on the rescue of the socialist Homeland and its gains.

Other principles of information space formation gave the chance to get much more deeply into the consciousness of the person. Together with rational ways of impact on consciousness there were ways to call irrational actions. They carried out destructive action, suppressed a rationale and to force people to serve the purposes of those who established them. In this direction, in due time big practices were made by Goebbels's Department.

During the almost entire period of occupation Hitler's ideologists and the occupying authorities applied a direct way of impact on the consciousness of the Ukrainian population. From the protocol of a meeting of Hitler with Rosenberg, Lyammers, Keitel, and Goering of July 16, 1941, about further plans concerning Ukraine and its territory we see that there were to develop concrete principles concerning policy in the occupied areas. Here Hitler agreed with Rosenberg that a victory would be received quicker if the German army had the support of the local population. He also agreed with the opinion that in each commissariat it was necessary to develop the attitude towards the population. In Reykhskomissariat Ukraine, according to Rosenberg, it was necessary to put in action "cultural guardianship", it is necessary to wake historical consciousness Ukrainian, to create in Kyiv favorable conditions for education... (Косик, 1998, 172).

Implementing the program of influence on the local population the German administration addressed to historical consciousness of Ukraine 
Almost in each journal number "Vinnytsia Messages", articles about the famous Ukrainian figures and national avengers who fought for the freedom of the Ukrainian people were published. In the same articles the fascist army was compared to fighters for its freedom. In many articles, Mikhail Grushevsky's activity (Вінницькі вісті, 1941, 2), Ivan Gonta Philip Orlik (Вінницькі вісті, 1941, 2), Nikolay Hvylevy (Вінницькі вісті, 1941, 2), Ivan Kotlyarevsky (Вінницькі вісті, 1941, 3), Lesya Ukrainsky (Вінницькі вісті, 1941, 3), Boris Grinchenko, etc. (Вінницькі вісті, 1941, 3).

Continuing the political line the Minister of East Occupied Territories A. Rosenberg during the stay in Kyiv addressed consciousness Ukrainian. He delivered a speech in which he explained a place and tasks for the Ukrainian in new Europe and said that the Ukrainian culture would be revived be with the assistance of the Germans. It was noted that traditions, customs, native language, dances, freedom of religion should be renewed. The German power took responsibility for a cultural revival of Ukraine. Respectively and Ukrainians had to become consciously and readily on service of the future destiny (Нове Запоріжжя, 1942, 1).

To influence on consciousness of the population of occupied territories more effectively the occupational administration used the most modern levers and well- known communication technologies: opened movie theaters, adjusted and supported work of theaters where performances of the famous Ukrainian directors with the heroic past of the Ukrainian people - the performance "The Zaporozhets Beyond Danube", "Taras Bulba", etc. were put (Волинь. Часопис для Волині, 1941, 4).

From the chronicle of the "Vinnitskiye Vesti" newspaper, we see the work of the "Vinnytsia radio station" which program was made so that works by the Ukrainian poets and composers as often as possible were distributed. During the day, for example, on October 3, 1941, works by the Ukrainian composers performed by symphonic and wind orchestras sounded, sang the Ukrainian theatrical chorus, read the best samples of the Ukrainian poetry and prose (Вінницькі вісті, 1941, 4). Such reception made an impression at the local population that the Ukrainian culture revives, so behind it would revive also economic life.

The method of a big lie was a favorite method of Goebbels. It was applied among troops of Wehrmacht and the military of the Red Army and in occupied territories, it is successfully applied and reasonable A. Hitler in due time. Studying Goebbels's activity in the context of propaganda the historian V. Lisichkin concluded that the propaganda machine of Nazi Germany staked on what in the USSR the population got used to trust politicians and therefore, dissemination of any false information will be perceived by people positively, 
with trust (Лисичкин, Шелепин, 1999, 24). То open true plans concerning the fate of the population of occupied territories the Hitler's government had no intentions, therefore, the outright lie became the main instrument of Nazi propaganda.

This principle of creation of information society became one of the most important in the policy of the Hitler's government in the occupied territory. A large number of the examples recorded in magazines and newspapers of the period of occupation demonstrates to it. So, in the "Volyn magazine" of September 21, 1941, we learn how the German leaders resorted to bald open lies and misinformation of the population. In the diary "Soldatenzeitung der Ukraine" the positive characteristic Ukrainian allegedly was given. The author, the famous expert on the Ukrainian traditions, Gekel, reported about the Ukrainian and state traditions, big Ukrainian princely the state, eternal fight of the Ukrainian people against the Moscow and Polish aggressors which repeatedly encroached on independence of Ukraine. "That the Ukrainian people, certainly, cost to fight for freedom of Europe per the present on side of Germany" (Волинь. Часопис для Волині, 1941, 3). So, the German soldiers were given it seems manuals, to be respectful to the Ukrainian population, to help to fight for the rights and freedoms.

One more graphic evidence of occupational lie was the campaign of children school training. At the beginning of August 1942 in all occupied areas of Ukraine entering Reykhskomissariat Ukraine it was proclaimed a set of children of seven-year age for training at high comprehensive school. Lists of children were made and it was noted them compulsory education (Державний архів Сумської області, фонд 1955, оп. 1. спр. 12. 1. 1, 2, 19, $26,61)$. It would seem, here it, the real educational policy, at last children had an opportunity to study in the native language. But we see the real policy which was pursued by Hitler already on Erich Koch's reaction that in Ukraine not only 4-great national schools but also a set of other schools and gymnasiums for which he did not grant permission work. He noted that when in Germany the growth of education stood still and even the vital professions such as a doctor, could not have necessary development. It was not important at all whether in Ukraine education which could plan the German authorities only in 10 years will increase (Чайковський 1990, 168).

As a result of such a policy which testified to the present plans of fascist Germany the order of a Reykhskomisar of Ukraine Koch about closing in Ukraine schools and institutes and about sending teachers and pupils for forced labor to Germany was published on October 24, 1942. At the same time, he demanded that, except 4-great national schools, there was no school to which it did not allow. Paid attention to that, as 4-great schools could work 
only when he was convinced of their need (Немецко-фашистский оккупационный режим (1941-1944 гг.), 1965, 169).

How the Ukrainian children studied, we can judge by memoirs of V. Kachanov, the pupil of Akimovsky elementary school of the Zaporizhzhia region. He remembers that during occupation neither he, nor other Ukrainian children could study. Only the German children studied. He remembers only as the occupying authority concerned his mother in commandant's office to beat her. And on February 1943 they were expelled from a home (Державний архів Запорізької області, фонд 1676, Оп. 2, Спр. 3, 3).

At the same time about not to lose arrangement and to create illusion free public life the occupying authority promoted formation of regional centers of Land committees which had to be engaged in agricultural works and train experts for work in large-scale enterprises. So, in. The first was exactly created by the Regional Land Department of District Administration. At once after creation the Department started to found the circles of "Rural Owner" in each community on all areas. For this purpose, the Regional Land Department gave out and distributed in all regional land departments of an area the document of such contents that allegedly once, in far times. Ukraine was a granary of Europe. The people of Ukraine became unfortunate. They were removed into place and brought together to ethnographic vegetation, the slave.

Bolshevist collective farms finally destroyed the Ukrainian peasantry. Modern times have come. It is created by our independent lives... There is a wide field for the device of various courses. The main purpose is to teach farming to develop it. On those courses, farmers learn about new in agriculture, livestock production, engineering science, gardening, truck farming, poultry farming, and other industries (Волинь. Часопис для Волині, 1941, 3).

Information which is contained in sense of this document was partially truthful and therefore drew attention of the local peasantry, but further and there was an outright lie which purpose was a formation of opinion about "the big future", about obtaining qualification, about creation of appropriate working conditions - all that the Ukrainian peasants aspired for a long time to.

Departments of Propaganda which were not only in each area but also in each area, the city made a maximum of efforts for strengthening information and psychological impact on the population. What only they did not resort to. In one of newspapers "Volyn" of December 18, 1941 article was written where the Ukrainian students continuing the general historical way with the German youth studied at the universities of Germany long ago. In the German higher education institutions such famous Ukrainian figures as, I. Khmelnytsky, I. Paletika, V. Stefanovich, S. Todorovsky and many others 
studied. G. Skovoroda aws known to respect the Germans more. For confirmation of these words there was the small statistics submitted such: in a summer semester, 1941-1942 academic years 464 students from other countries, among them 319 Ukrainian studied at the German universities. This number increased at the expense of students from Volhynia and Galichina (Волинь. Часопис для Волині, 1941, 3).

Demonstrating to the Ukrainian population aspiration of the German administration to bring it out of darkness and to give the chance to reach in the cultural and educational level of what the German people already had and the best way was the purpose of such publications to prove it, showed results of cooperation of the Ukrainian and German people throughout several centuries. It should be noted that such information completely contradicted that educational policy which was pursued in occupied territories by Erich Koch.

That's no doubt that both sides were not frank. The soviet leadership tried to show the Germans as the real monsters and confirm the above-stated indications. The German leaders constantly reminded about negative sides and the Soviet collective-farm system, and they not bad managed it as for this purpose there were serious reasons. It would be desirable to note the consequences of the occupational policy of 1941-1944.

In the periodical press and cards constantly compared former life Ukrainian to what it would be in the future, noted how badly they lived of Bolsheviks and which bright future could be for them in future with the assistance of the Germans. The thought that Bolsheviks according to plan organized hunger in Ukraine was in large quantities imposed, their policy was directed to extermination of the Ukrainian nation. To the Ukrainian people the feeling of uncertainty imparted. "It deprived of any human dignity. Had all aspirations of the personality to be limited to such an extent only to calm the physical hunger" (Волинь. Часопис для Волині, 1941 379, 2).

The population of occupied territories convinced that the Soviet Union prepared for the approach for the whole world. Having built powerful army, made various weapons all possible forces for a campaign were mobilized for the West. (Сумський вісник, 1941, 3). Streams of misinformation were directed to the population of occupied territories, still doubted, to support the occupational mode and to create the appearance that in the future Ukraine would become an independent state.

In the conditions of war it was necessary for any psychological influence the truth and its certain volume. In this background also necessary portions of false data were allowed. But the method of "the partial truth" became the most effective, it consisted of the differentiation of described events, allocation of true, but isolated facts and their identification with an event. In more general 
formulation of the question - creation based on the facts of false information structure. Such difficult educations received the name of political myths (Бурцев, 1981, 27).

Such an obvious example is the message of the Kharkiv Regional Commissariat about the strategy of the Red Army at retreat from the territory of the Ukrainian SSR. Propagandists noted that the Soviet troops, receding, destroyed everything on the way that nothing remained to the population which could not leave the territories occupied by the German army (Державний архів Харківської області, фонд 2984, Оп. 1. Спр. 7, 41). It is necessary to recognize that partially this information was truthful. Many miscalculations and mistakes which were made by Soviet leadership and the Red Army at retreat became a reason for the German propaganda and propaganda. People who witnessed such retreat of the Red Army were already easy to be convinced of anything.

From articles that contain in the "New Ukraine" newspaper issued with the assistance of the occupying authority we see that with the arrival of Hitler's army Kharkiv prospers happened to restore a spiritual life. Authors of articles claimed that people should watch a performance moving daily gather to watch a performance With the assistance of the German command which cared for the spiritual life of residents there were put 18 elementary schools where about 3 thousand were studied to work. There were opened 6 regional libraries (Державний архів Харківської області, фонд 2984, оп. 1, спр. 7, 59).

A famous Ukrainian historian A.V. Skorobagatov wrote about a true life realities in the Kharkiv region. He noted that the occupational policy on the Kharkiv region differed from the policy in Rekhskomisariat of Ukraine radically. It took place when the government of this territory was transferred to the commander-general field marshal Walter von Reichenau (Скоробагатов, 2004, 66-68). Before the occupation of the Kharkiv region the German troops were already strongly exhausted in the fight against the Soviet Army, broken the plan of "lightning war" and to that Rejchenau demanded further draconian measures in the fight against the Soviet guerrillas and underground workers (Державний архів Харківської області, 60-61).

The Wehrmacht established a new order in Kharkiv with extreme cruelty. In the first days of occupation on balconies of houses and cable columns of the city 116 people were hung up. It was terrible to go outside, everyone was suspected of cooperation with Bolsheviks (Харьковщина в годы Великой Отечественной войны, 1941-1945 гг. 1965, 552).

So, from the first days of occupation against civilians the Nazis it made cruel repressions. So intimidated the population and showed what waits for those who would not carry out the order of military authorities. 
Life in the occupied Kharkiv was very heavy. Lack of food, an opportunity to earn a living, or to somewhere exchange something edible, a curfew - all this affected opinion of Kharkiv citizens of rather new power. And even opening and work of theater or attempt of the occupying authorities to begin academic year did not make people more favorable to military authorities in the city (Скоробагатов, 2004, 279-280).

Throughout all war, the Hitler's government tried to create information space not only in occupied territories. During war it was important for the fascist leadership of Germany to support the trust among the German population that was an inexhaustible source of military forces, illusions of constant victories and big achievements of invincible German army. People manipulation through information influence was possible because there was feedback. All schemes of information influence worked in German society on the eve of and during World War II because grew consciousness of many people. Here, certainly, a role was played not only by the principle of submission of information, and, first of all, a difficult economic situation of the country and each German citizen in particular.

German society existed also a powerful tool of realization of receptions and methods of creation of artificial information space - the mass media (MM). Rather figuratively the founder of the Society of Krishna told about the action of media:

"Now for anybody, not a secret that using mass media it is possible with unprecedented to create skill a veil of deception and illusion so nobody will be able to distinguish the truth from a lie, reality from fiction" (Лисичкин, Шелепин, Боев, 1997, 37).

Support of the German population was also necessary also because of most of the printing products, transfers of broadcasting and movies for the occupied areas created in Germany.

Fixed assets of dissemination of information were as it was already noted, radio, the German information bureau, and the press. Therefore the first task which faces the Hitler's government in occupied territories of Ukraine, in the shortest possible time to restore broadcastings and printing houses of the regional, regional press as most effective remedies of formation of information space (Панарин, 2006, 154). The population of Ukraine was in the specified information space, daily scooped information from the press, broadcasts, from screens of TVs. Being often in the world of the symbols which are torn off from reality, they went even against own interests. The reality faded into the background. In this sense of people became dependent. Several ways of effective information actions were fulfilled. Occurred socalled "brainwashing". Mind zombies of people was carried out. It was 102 
created obedient to the person, the people turned into manageable weight (Дичев, Бийчанинова, Берестенко, 1993, 68).

A very interesting and productive method was also the method of a declaration of ideals in using appeals. According to the political scientist Mr. Pocheptsov a considerable part of people especially in the rural zone almost did not read books. It gave the chance to impose to people thought in the form of slogans. A slogan had to be short, attractive and expressive one (Почепцов, 1998, 62-63).

It should be noted that the majority of headings of articles in the occupational press had the character of slogans, for example, in the Vinnitskiye Vesti newspaper - "The peasantry - the vital force of Europe" (Вінницькі вісті, 1942, 1), "Germany wins on all fronts" (Вінницькі вісті 1941, 1), "Awakening to new life" (Вінницькі вісті, 194, 3). Such slogans aimed to show to the population of occupied territories what aims are pursued by Hitlerite Germany according to the solution of the Ukrainian question.

Also the method of a denial of information influence of the opponent was actively used. This method was rather often used by all Departments of Propaganda of the Ministry of East Occupied Territories and Wehrmacht. It consisted of content that the German propaganda tried to deny that information which got to the population of occupied territories through the Soviet channels are banned: newspapers, leaflets, radio, etc. So, for example, when the German citizens listened to the "Swiss" radio stations or BBC Frich as known for the Germans as the radio commentator discredited completely propaganda efforts of allies (Герцштейн, 1996, 241).

A similar situation developed when the German occupational administration disproved the Soviet messages and tried to show information from a different angle of sight. For example, we will provide a fragment to the political article in the "Wolhynien newspaper", Nr. 25 (53), vom 29 Maerz 1942, Rowno. An article can be considered as one of many responses to Stalin propaganda in which crimes of the fascist mode are reflected in occupied territories and the real aspirations of Hitler. In the article, it is said that all efforts of Soviet leadership to break force at the head of which there is a big European Adolf Hitler were vain. "Nothing surprising as on flags which unite the whole of Europe in the fight against Asian Moscow of the user also the family is clear to Europeans appeals" (Центральний державний архів вищих органів влади та управління України, фонд 2, оп. 1, спр. 103, 29).

To deny information of the Soviet press that the German government broke the nonaggression pact signed by both parties in August 1939 occupational administration in newspapers, in particular in the "Volyn magazine" of December 25, 1941, proved that treason happened from Stalin. 
Proofs that representatives of the Soviet party circles showed to the American correspondent V. Kerel that Stalin used were provided the contract is signed thoroughly to be prepared for war. In the article it is noted that it is Stalin war and its purpose - to destroy the European people (Центральний державний архів вищих органів влади та управління України, 2) This strategy of Stalin was confirmed in other publications "Moskovia against Europe" in which the opinion that the Russian monarchs with HVIII of a century sought to take and divide Europe is leading. In confirmation of it the example is given: the partition of Poland three states of 1772-1795, the initiator whom Russia (Центральний державний архів вищих органів влади та управління України, фонд 2, оп. 1, спр. 103, 2).

The famous historian A. Necreech considered that the non-aggression pact between Germany and the Soviet Union was used by Stalin for strengthening of the Soviet Army in war with Finland. According to him, Stalin planned participation of the USSR in the large-scale European war, but at the same time he was afraid to face the union of the leading capitalist states and first of all was afraid of change of front England and its conspiracy with Germany against the USSR (Некрич, 1995, 325-327).

The former officer of GRU V. Suvorov considers that Stalin used Hitler to begin the war in Europe. But this thought only confirms the existence of the Soviet doctrine which provided warfare in the territory of the opponent. Suvorov notes that Stalin prepared for drawing a preventive strike and even time was defined (Суворов, 1990, 175). Therefore there was enough information which gave a reason to the German leaders to speculate on this thought.

In the "New Zaporizhia newspaper" of August 19, 1942, we read an article about how Bolsheviks justify with a lie the real situation at the front. As the people do not want to support Soviet in the authorities in, she somehow to hold the positions, almost in each construction from fronts tells about the achievements and victories over the German army. Actually "received nothing for all the time of approaches, and only small huge losses in manpower and military equipment (Нове Запоріжжя, 1942, 3). In the same newspaper, we read also about losses of the Red Army and words about losses of the German army in northeast loops of the Don arch.

An active development of propaganda naturally generates counterpropaganda. It is one of the methods of information and psychological impact on people of the occupied Ukrainian territories. According to the same G. Pocheptsov, counter-propaganda is a response to communicative actions of the opponent, for example, a denial of this or that information that goes from the opponent. Opponents, Hitler's Germany and the Soviet Union actively studied 
propaganda and propaganda activity and messages of each other to prevent their mass impacts on consciousness Ukrainian (Почепцов, 2001, 68).

First of all, it should be noted that the leader of Fascist party Adolf Hitler and therefore the considerable stream of propaganda of Soviet leadership was directed against it was one of the main objects of propaganda. The Hitler's team in the counterpropaganda activity worked on a problem of publicizing of activity of Hitler and Stalin in a foreshortening, convenient for them. So in one of the brochures "Adolf Hitler and children" who extended on the occupied territory in the fall of 1941, it was said:

"Cut off for long years from the rest of the world by Bolshevist executioners, you could not know the naked truth.

Constantly lied to you and inspired that the German people hate Adolf Hitler, across Germany blood flows the river and that the world does not know the cruel despot.

The Jewish propaganda especially sought to blacken the person Fyurer and it is clear that Jews also hate him as it is loved by the German people...

We will try to show you how the people of Germany and especially children love Fuhrer and as he loves children and the people...

Adolf Hitler will destroy the devil system of the Bolshevism and on your Homeland and will give to your people the world, happiness and an order" (Гогун, 2004, 342).

All these words were followed by photos with the image of Hitler who communicated with children and worked on the solution of global problems.

In the German policy also using of anti-Semitic moods was not new. To receive the favor of the local population the German leaders in occupied territories imposed a thought that in all vital difficulties, in the period of the Soviet power Jews and Bolsheviks were guilty. In the directive of the Supreme Commander of Wehrmacht in September 1941. It was said: "Fight against the Bolshevism demands ruthless and vigorous actions first of all against Jews who are the main carriers of the Bolshevism" (Коваль, 1999, 164).

Similar example "Address to the population of occupied territories of Reykhkskomisar Erich Koch's Ukraine: "England is your enemy as there is it the enemy of all European people. This war was imposed on Europe by England! She is an ally of the Bolshevism! It has to be beaten because the world and wellbeing can come only when the victory over England is won. Put your gratitude of Germany and your contribution to fight against England the work..." (Центральний державний архів вищих органів влади та управління України, фонд 57, оп. 4, спр. 185,1).

In propaganda also the Soviet power adhered to the same principle. So, the address to fighters of the Red Army, the guerrilla and the population of 
temporarily occupied territories was published in the "Communist newspaper" No. 174/6654 of July 23, 1941: "Beat mad fascists! The impudent enemy perfidiously attacked our native Homeland, the blood-thirsty fascism wants to enslave our freedom-loving people, our home ground... fascists open wide to fall to the ground of the blossoming Ukraine, to its forests and the rivers, to riches of our people. We will not allow it, we will not assume that the mean enemy scoffed at ours of honor and freedom. By fire and sword we will expel the Hitler swine from the cities and villages..." (Центральний державний архів вищих органів влади та управління України, фонд 3206, оп. 2, спр. 72, 10).

From this, the important principle of military propaganda follows: any attacks to the country and her leader, any propaganda, discredits the power, only enhances the commitment of those who else not quite identify themselves with the state system. This problem cannot be solved even by the cleverest and skillful propaganda. It can solve only a military victory. At the adverse course of fighting such is propaganda, in general, it is doomed to failure. "Extremely low efficiency of propaganda of the Red Army on the German troops in the first two years of war of Hitler's Germany against the USSR is explained by these reasons. In this case, information influence faced also a rejection of hostile propaganda, and strong nationalist sentiments... If the level of a moral and political condition of the opponent is insufficiently high, and fighting develops unsuccessfully for it, then psychological influence has every chance to be productive" (Крысько, 1999, 90).

This fact is confirmed after the defeat of the German armies near Stalingrad when weakened and is disappointed the German soldiers with the whole parts and divisions were given in captivity.

One more significant fact from the report of guerrilla connection of the colonel Melnik in villages of the Rivne region where nationalist groups of bulbovets and Banderovites spread provocative rumors about that, as if the Soviet guerrillas destroy civilians, the population sometimes fled from the village to the forest at our approach.

All population is hostile against Germans, traitors of the Homeland. In many villages which we passed the population addressed guerrillas with complaints to criminal acts of police officers, heads and those who served the Nazis.

The moral and political spirit of most of the peasants became sharply hostile the "German invaders" (Центральний державний архів вищих органів влади та управління України, фонд 4620, оп.3, спр. 112, 74а-75.).

The concept of Nazi policy in occupied territories of Ukraine provided, first of all, the creation of the powerful information space placed at service to the "Third Reich" and directed to a clear victory in this war. The main 
objective of information space is to win the favor of the local population to the occupying authority and its support in the fight against the Soviet Union during an initial stage of the war.

\section{REFERENCES}

1. Камінський Є., Дашкевич А. 1998. Політика США щодо України. Витоки. Концептуальні основи. Практична еволюція. Київ : Політична думка.

2. Почепцов, Г.Г. 2001. Информация \& дезинформация. Москва : Эльга.

3. Шрейдер Ю.А. Шаров А.А. 1982. Системы и модели. Москва : Радио и связь.

4. Панарин И.Н. 2006. Информационная война и геополитика. Москва : Издательство “Поколение”.

5. Hitler A. 1953. Hitler's Table Talk 1941-1944. Trevor-Roper. London.

6. Макаревич Э. 1993. Германия: програмирование человека. Диалог. Минск: РУП “Початкова школа”. № 4.

7. Крысько В.Г. 1999. Секреты психологической войны (цели, задачи, методы, формы, опыт). Минск: Харвест.

8. Прокофьев В.Ф. 1999. Тайное оружие информационной войны. Москва : СИНТЕГ.

9. Орлов Ю.Я. 1985. Крах немецко-фашистской пропаганды в период войны против СССР. Москва: Изд-во Московского университета.

10. Жуков Д.А. 2000. Власовцы и нацистская пропаганда. Москва : Яуза-пресс.

11. Дашичев В.И. 1973. Банкротство стратегии германского фашизма: Исторические очерки. Документы и материалы. В 2 т. Т. 2. Агрессия против СССР. Падение «Третьей империи» (1941-1945 гг.). Москва : Наука.

12. Гогун А. 2004. Черный PR Адольфа Гитлера: Документы и материалы. М.: Эксмо, Яуза.

13. История ВКП(б). 1938. Краткий курс. Под редакцией Комиссии ЦК ВКП(б). Москва : Политиздат.

14. Ortwin Buhbender. 1978. Das tötende Erz. Deutsche Propaganda gegen die Rote Armee im zweiten Weltkrieg. Seewald Verlag Stuttgart.

15. Цыбмал В.И. 1995. О концепции информационной войны. Информационный сборник «Безопасность». Москва : Фонд нацтональной и международной безопасности. № 9. 
16. Фурманов Д.А. 1985. Чапаев. Мятеж. М.: Правда. Сайт «Военная литература». Доступ 27 июля 2015 http://militera.lib.ru/prose/russian/ furmanov2/03.html.

17. Бурцев М.И. 1981. Прозрение. Москва : Воениздат.

18. Кочергин, А.Н., Коган В.3. 1980. Проблема информационного взаимодействия: философско-социологический анализ. Москва : Наука.

19. Немецкая пропаганда на территории СССР. 2013. Москва. Военное обозрение. Доступ 30 июля 2015 https://topwar.ru/30938nemeckaya-socialnaya-reklama.html

20. Лисичкин В.А., Шелепин Л.А. 2005. Война после войны: Информационная оккупация про-должается. М.: Изд-во Алгоритм, Изд-во Эксмо.

21. Верба I.В. 1999. Кость Штеппа (окончание, на укр. языке). Український історичний журнал. № 4. Київ : Інститут історії України НАН України.

22. Волинь. Часопис для Волині. 1943. 7 жовтня.

23. Вінницькі вісті. 1942. № 30.

24. Вінницькі вісті. 1942. № 33.

25. Вінницькі вісті. 1942. № 39.

26. Вінницькі вісті. 1942. № 43.

27. Вінницькі вісті. 1942. № 44.

28. Вінницькі вісті. 1942. № 47.

29. Окороков А. 2007. Особый фронт. Немецкая пропаганда на Восточном фронте в годы Второй мировой войны. Москва: Русский путь.

30. Косик В. 1998. Україна Другій світовій війні у документах: Збірник німецьких архівних матеріалів. Львів: Львівський національний університет ім. Івана Франка. Т. 2.

31. Вінницькі вісті. 1941. № 13, 28 вересня.

32. Вінницькі вісті. 1941. № 18, 10 жовтня.

33. Вінницькі вісті. 1941. № 22, 19 жовтня.

34. Вінницькі вісті.1941. № 31, 20 листопада.

35. Вінницькі вісті. 1941. № 36, 7 грудня.

36. Вінницькі вісті. 1941. № 38, 14 грудня.

37. Нове Запоріжжя. 1942. № 67 (81), 7 липня.

38. Волинь. Часопис для Волині. 1941. 1 вересня.

39. Вінницькі вісті. 1941. № 15.

40. Лисичкин В.А. Шелепин Л.А. 1999. Третья мировая война. Москва : Институт социально-политических исследований $\mathrm{ACH}$.

41. Волинь. Часопис для Волині. 1941. 21 вересня. 
42. Державний архів Сумської області (далі - ДАСО). Ф. 1955. Оп. 1. Спр. 12.

43. Чайковський А.С. 1990. За нами Большая земля: Помощь советского тыла в организации народной борьби против фашистских захватчиков на временно оккупированных территориях Украины, 1941-1944 гг. Киев: Вища школа.

44. Немецко-фашистский оккупационный режим (1941-1944 гг.). 1965. Сборник статей. Под редакцией Е.А. Болтина. Москва : Политиздат.

45. Державний архів Запорізької області (далі - ДАЗО). Ф. 1676. Оп. 2. Спр. 3.

46. Волинь. Часопис для Волині. 1941. 7 вересня.

47. Волинь. Часопис для Волині. 1941. 18 грудня.

48. Волинь. Часопис для Волині. 1941. 28 грудня.

49. Сумський вісник. 1941 р. № 14, 4 грудня.

50. Державний архів Харківської області. Ф. 3077. Оп. 1. Спр. 7.

51. Державний архів Харківської області. Ф. 2984. Оп. 1. Спр. 2.

52. Скоробагатов А.В. 2004. Харків у часи німецької окупації (1941-1943). Харків: Прапор.

53. Державний архів Харківської області. Ф. 3086. Оп. 1. Спр. 1. 39 арк.

54. Харьковщина в годы Великой Отечественной войны 1941-1945 гг. 1965. Сборник документов и материалов. Харьков: Прапор.

55. Лисичкин В.А., Шелепин Л.А, Боев Б.В. 1997. Закат цивилизации или движение к ноосфере. Экология с разных сторон. Москва: ИЦ Гарант.

56. Дичев Т., Бийчанинова А., Берестенко М. 1993. Информационный Чернобыль. Советская Россия. Москва : Военная мысль. № 6.

57. Почепцов Г.Г. 1999. Информационные войны. Основы военнокоммуникативных исследований. Ровенский институт славяноведения Киевского института «Славянский университет». Ровн : Волинські обереги.

58. Вінницькі вісті. 1942. № 54.

59. Вінницькі вісті. 1941. № 28.

60. Вінницькі вісті. 1941. № 14.

61. Герцштейн Р.Э. 1996. Война, которую выиграл Гитлер. [перевод с английского]. Смоленск: Русич.

62. Центральний державний архів вищих органів влади та управління України. Ф. 3206. Оп. 2. Спр. 86. 
63. Центральний державний архів вищих органів влади та управління України. Ф. 3206. Оп. 1. Спр. 103.

64. Некрич А.М. 1941, 22 июня. 1995. Москва: Памятники исторической мысли.

65. Суворов В. 1990. Ледокол. Кто начал вторую мировую войну?: Неофантастическая повесть-документ. М.: АСТ.

66. Нове Запоріжжя. 1942. № 75 (89). 19 серпня.

67. Коваль М.В. 1999. Україна в Другій світовій і Великій Вітчизняній війнах (1939-1945 рp.). Київ: Видавничий дім «Альтернативи».

68. Центральний державний архів вищих органів влади та управління України. Ф. 3206. Оп. 1. Спр. 103.

69. Центральний державний архів вищих органів влади та управління України. Ф. 4620. Оп. 3. Спр. 100, 112. 


\section{SECTION 3.1. \\ MEDIA AS A MECHANISM FOR IMPLEMENTING THE INFORMATION POLICY OF THE WARRING PARTIES}

The media play a huge role in shaping and functioning of public consciousness. A special impact of the media is known to take place in the period of military conflicts when leaderships of warring countries are interested in a victory at any price.

Since the invention of I. Gutendergom printing press in 1450 began to talk about the impact of the printed word on the public consciousness. History shows that "at first only the ruling clique of society realized the potential social influence of the printed word. Many state leaders being afraid of consequences of general literacy and availability of printed materials sought for control over publications to disfranchise opposition". The similar fear before the influence of media still exists in many societies with totalitarian regime where leaders suppress or control activity mass to remain in power.

The period of 19 - the beginning of the 20th century is marked by the distribution of literacy and development of technologies in various areas that led to the emergence of new forms of mass communication (the invention of the phone, radio). Since then, concern about the consequences of mass media exposure has become a sphere of activity aseducated elite and individuals and all groups of the society.

The broadcasting is considered to the second type of the media after the print media. The use of radio waves allows an information to be transferred to unlimited distances and on the air. A history knows a set of examples of the influence of broadcasting on public consciousness. This influence could have both positive and negative effects.

The emergence of television marked a new stage in the development of public consciousness technologies. Today television seemed to be the most widespread channel of information influence on masses. Due to ample communication opportunities "effect of presence" is the most effective instrument of management of outlook of the personality at the present stage. The television (unlike printed media and radio) influences on two bodies of perception at once - hearing and sight, - thanks to what the viewer obtains the bigger volume of information when the listener or the reader for the same time. In turn, it affects also the impact of television on public consciousness: 
"Possibilities of telecasting allow to transfer the maximum quantity of information in the form in which it is most easily acquired, providing the greatest influence".

In the last decades the worldwide computer network actively is being developed. The media information takes an important place in network. In a worldwide web there is a set of electronic versions and digests of printed media (change the contents in real-time), Internet radio, network telecasts.

Thus, in the conditions of the information society people are influenced by all kinds of mass media that manipulate their minds. So at the expense of what similar manipulation does become possible and who is "manipulator"?

At the beginning of the 20th century the German philosopher Spengler foresaw the role of information in a person's life. In the "The Decline of Europe" he wrote: "In the near future only three or four world newspapers will direct the thoughts of the provincial press and control the consciousness and will of the people". According to his statement in the $20^{\text {th }}$ and the next centuries "periodicals will play an extremely important role. It will influence the political and public relations and also the military conflicts" (Шпенглер, 1998, 191-193).

The 20-th century, really, became a time when mass media, in particular newspapers, magazines and radio developed and affected public opinion. Since World War I, the media, in particular newspapers and leaflets, were always active participants of armed conflicts. It is possible to consider the attack on the radio station in Gleyvitsa. Radio and newspapers became the tool for distribution an information with the high speed and necessary comments. Also the leader of the Italian fascists B. Mussolini understood an important role of the press. According to his colleagues in planning the military operations he paid more attention to headings published in newspapers than military operations of Italy.

Most theorists and researchers define periodicals the place in the life of society, especially during politically active periods and at the time of armed conflicts. Periodicals are considered to the main source of information, discussion and protection.

Already in the late 20 -s of $20^{\text {th }}$ century Hitler and other leaders of the German National Socialist Party understood that the periodicals had to become one of the most powerful tools in the fight for establishment in Germany of the Nazi regime.

As soon as Hitler came to the power he announced that the press of the Third Reich should be an object of (Gleichschaltung known as the Nazi political concept of the conquest of all spheres of Germany's life. It was in the interests of the national socialist mode. At once after the formation of the 
Ministry of National Education and the Promotion of Germany headed by I. Goebbels all newspapers and magazines of the Third Reich appeared under strict control. All oppositional editions were forbidden by the law on the press adopted on October 4, 1933 by the Nazi regime. This law deprived of publishers of the right to make independent decisions in the field of editorial policy. Such rights were transferred to editors who were, according to the management of the Reich, "carriers of public concerns". The journalism appeared profession of the state value. To control the edition of periodicals completely it was necessary to put journalists under complete control of the national socialist leadership. In 1935 for this reason there was distributed the order on obligatory membership of journalists in the National Socialist Workers' Party of Germany (NSDAP). So way a considerable part of the qualified journalists lost opportunities to be engaged in the activity (Волковский, 2003, 192).

The ban of the Berlin's Press Conference which actually was a public association of capital journalists became an important step in total control over periodicals. The government motivated it with the fact that only the state could have rights for the dissemination of information. But it was created "Administration Press Conference". Earlier in 1934 Max Amann reconstructed a very influential professional organization called the Union of Newspaper Journal Publishers. It became the Department headed by him personally. In the structure of this department was a number of various mass media departments and the periodical press. That year under the observation of NSDAP it was reconstructed known "German News Agency" and united these authorities in one big agency which actually became the "German Information Bureau and NSDAP" (Вороненкова, 1999, 295).

Liquidation of newspapers and magazines which belonged to Jewish became the following step of Nazi policy. They had to sell the editions to the German owners. It should be noted that the majority of newspapers and magazines belonged Jewish's periodicals. There were such editions as the Central Fereyns Tsaytung newspaper (Berlin, 1922-38) (Энциклопедия третьего рейха, 1996, 379]; also at this time, Zionist newspaper "Yudisha to a Rundsha" (1896-1938) gained great popularity. Well new editions, such as "Der Schild" established in 1921 by Association of the former Jewish military personnel appeared. More than three three dozen public newspapers and magazines which appeared during that period in Berlin, Frankfurt, Munich, and other cities, as a rule, were not political editions. They were addressed to various social groups of the Jewish population of Germany: young people, teachers, women, employees, etc. "The Der Morgen Magazine" (Darmstadt, 1925-38) reflected in the editions "German-Jewish Assimilation policy". 
Contrary to those editions monthly newspaper of M. Bubera "Year" (Berlin, 1916-24) became a tribune for those who preached the Jewish spiritual revival in Central Europe. Supporters of "Mizrakhi's" movement issued the monthly journal "Tsion2 (Berlin, 1929) (Периодическа печать, 1992).

Later "Crystal night" the Jewish press in Germany almost stopped the existence. The majority of editions were crushed. There was a mass emigration of Jews from Germany. The Nazi leadership decided to leave only the edition of the "Yudisha Nakhrikhtenblatt newspaper" (left since November 23, 1938) which limited the publication of official decrees and bulletins so-called "Imperial Organization of Jews in Germany" (Периодическа печать, 1992).

As soon as it was finished with the press belonging to representatives of the Jewish people, NSDAP established a total control and monopoly on Jewish periodicals. The Nazi government founded its own editions and own periodicals such as "Felkisherbeobakhter" which became an influential official newspaper of the Third Reich. A. Rosenberg headed it. In Berlin I. Goebbels established an own newspaper "Angrif" and started publishing it. There were some old newspapers which Goebbels personally monitored their contents personally (Энциклопедия третьего рейха, 1996, 380).

Thus if to trust statistics in 1932 year a total number of newspapers was 4700. In 1939 there were 3500, and in 1944 editions left 977 (Вороненкова, 1999, 302). This data demonstrates that an enormous work has been done to eliminate newspapers and other periodicals by the Ministry of National Education and Promotion because this press did not profess to support the ideological bases of National Socialist's Party.

It is necessary to recognize that in the first year of staying in power of the Hitler's government there were periodicals, conceptually unified, subordinated to Nazi policy and economic requirements. The number of Nazi newspapers annually increased. The following data demonstrate it. In 1932 at the initiative of the National Socialist Workers' Party 70 printing editions turned out to appear. In 1935 the Party already had 140 newspapers. In 1944 there were 352 newspapers (История Второй Мировой войны, 1974, 303).

No less important role was played by periodicals and printing materials and in the territories occupied by the German army. Except for troops of Wehrmacht in invaded territories promotion of propaganda by print press was carried out by the Ministry of East Occupied Territories. There were special structures and departments which were created for this purpose.

The structure of the ministry assumed at the disposal of the Reich commissioners the special departments of the propaganda. There were also 114 
included divisions of occupational administration known as village headman, burgomasters and representatives of other office ranks. The structure provided institutions of regional governments. The village headmen should have provided the population with propaganda materials. If in some villages the newspaper and the leaflet were not got the headmen would be able to bring newspapers and read its independently. It was made a special order of reading reports of the German Supreme command to the population. That necessary information constantly was accompanied by each resident of the cities and villages. Special boards in the most crowded places were established where posters and leaflets had been pasted and hung.

In the Ministry of National Education and Promotion of Germany it was created a special "East" department with "Vineta". This branch of power carried out coordination and the management of propaganda campaigns in the occupied territories directed against the USSR.

The occupational administration applied various forms of promotion through the edition of newspapers and magazines Ukrainian. They were as demonstration at movie theaters of special movies and an evident propaganda in the form of posters and leaflets, documentary exhibitions and also theatrical performances. It was broadcasted in Ukrainian, Russian and other languages. But influential means of periodicals remained the most important ones.

As it was stated above in the previous section, at the front and on occupied territories special propaganda groups worked with the Hitler's army. Each of them also had separate departments. So the Wehrmacht had high hopes on a group of" South" which serviced by the "Propaganda-Abteilung U" battalion. Their task included propaganda activities among troops of Wehrmacht and the psychological processing of military and the population of the enemy (Орлов, 1985, 31).

On the eve of military operations on June 6,1941, by the chief of staff of General headquarters of Wehrmacht it was issued the directive where it was instructed in a strengthening of companies of promotion and departments which were responsible for this site of work as experts from propaganda activities. There were entered the departments of censorship which had to monitor the maintenance of the press in the occupied territory in German and local languages. Also, "the fact that the main objective of the press is the calming impact on the population of occupied territories to keep him from any resistance" (Коваль, 1988, 157-158).

In the middle of July 1941 at a meeting of the Supreme Council of the Reich the decision to renew the Ukrainian press for more active influence in the occupied territories was made (Косик, 1998, 240-241). As the Soviet printing enterprises were destroyed by the Red Army at a retreat, In most 
cases typographical equipment was delivered from Germany or from other occupied countries of Europe. The former head of publishing in Reykhskomissariat Ukraine G. Gornauyer wrote that for years of occupation (1941-1943) "the most part of the printed materials were made by the civilian population and army of Wehrmacht” (Ивлев, Юденков, 1988, 119).

From the beginning of the creation Reykhskomissariat of Ukraine there was formed the political authority operating according to instructions of the political department of the Ministry of East Occupied Territories led by A. Rosenberg. Its' task was to unify editions specially those that had been planned and had been already given. Political management consisted of 14 departments among which there was a department of the general promotion. Its structure included sections: promotion, the press, radio, cinema, foreign communications, economic recruitments, exhibition, service of troops, etc. (Черняков, 2006, 8). The Ministry of East Occupied Territories named Oettinger carried out the plans Vermwacht as the inspector (Державний Російський воєнний архів, фонд 1358, оп. 1спр. 1, 26).

In the Ministry of East Occupied Territories there was an accurate system of the organization to function the German and occupational press both and to provide it by necessary materials. The Head of that Department Zimmerman and secretary Ludwig Bulish organized the work. This department was engaged in providing propagandists with the equipment, film materials, paper for newspapers, loudspeakers, etc. (Державний Російський воєнний архів, фонд 1358, оп. 1спр. 1, 38).

In addition for service of the "East Press" in the Ministry of East Occupied territories the group being consisted of 18 where the head was Kikhben Schmidt was also in addition created. Serving of the press was the main function of this group, as well as an above-mentioned department: plans, card files. That Department had to hold information with helping of trips to places and control and processing of materials for the "East press". The newspapers and magazines extended in the occupied territory of the Ukrainian SSR directly submitted to it (such as "New word", "Voice..., etc." (Державний Російський воєнний архів, фонд 1358, оп. 1спр. 1, 40).

The political management of the press was rather influential. It was engaged in the development of accurate instructions for censorship for publishers of periodicals. The correspondents of the "East Press" served there. There was a bright propaganda in this department Germany in which it was told about the best in the world and in Germany. Brochures and books printed materials about Adolf Hitler and his aspiration to create a new Europe and about the German peasants and workers who were well off (Державний Російський воєнний архів, фонд 1358, оп. 1спр. 1, 42). 
The thesis about the dismissal of the people of the USSR from "the Bolshevism" was the main objective of the occupational press. Fight against the Soviet political and social order was the central point of this promotion. In it the major part was assigned to Jews (together with communists).

At the end of 1941 the Directive of the Reich Minister Rosenberg on the introduction of fascist orders in the occupied Soviet areas was published. It was noted that all questions connected with permission of issue of local newspapers had to be solved by the Reich Minister of the occupied East areas on the basis of offers Reichkomissar. It was noted that newspapers should have been to give out so much information how it would be necessary for the population. But at the same time, it was necessary to seek restriction of a number of local newspapers in a Reykhskomissariat. Further, it was noted that permission to the edition of local newspapers depended further on existence in each separate case of politically reliable publishers and editors. A necessary condition was the existence of enough German acceptable bodies (Німецькофашистський окупаційний режим на Україні, 1963, 65-66).

The power bodies of the periodical press supervision were created in each "Gebitkomissariats". From the letter of the commissioner of Uman to the General Commissioner we see that all articles and publications were published in the Umansky's newspaper "Ukrainsky Golos" and were exposed to captious censorship from propaganda departments of occupational administration. The letters arriving from citizens also underwent censorship, some of them were not included in newspapers (Центральний державний архів вищих органів влади та управління України, фонд 3206, оп. 2спр. 74, 4).

For local residents of the city and village he press was the main source of information. It is important to stress that a local radio regularly transferred its detailed reviews. Selections of newspapers were also available to readers of city libraries. The popularity of the press among the population was caused by regular publications of data on the situation on fronts of World War II and also orders and orders of local administration. Periodicals were read and discussed by millions of people in the occupied territories.It was extremely important for the occupational press to cover "Jewish problem". In the occupied territory the periodicals did not only inform the population by means of the occupying authority but also directly influenced a change of the attitude towards Jews from the local population. And that time it was significant to provide necessary help to them (Гитлеровская пропаганда юдофобии в прокламациях и карикатурах, 2005. 190, 56-58).

In the territory of the Ukrainian lands periodicals appeared to be under German control in the first weeks of occupation. Since the end of the summer 
of 1941 newspapers in Ukrainian had begun to appear already in all territory occupied by Germans. Since the fall of 1941 periodicals printed in each regional or regional center Since the fall of 1941 there were Distributed newspapers in city of Volyn.( such as "A free word" in Drogobyche, "the Voice of Poltavshchyna" in Poltava, "Sword" in Kryvyi Rih, "Nova of Dob" in Berdichev, etc.) (Черняков, 2006, 23-32).

For the purpose of unification and systematization of periodicals in the territory of Reykhskomissariat "Ukraine" the news department of the Ministry of East Occupied Territories developed a strong and an accurate system of divisions. One of them, in particular, "German Publishing Society in Ukraine with Limited liability" that took place in Lutsk. This edition was corresponded in German. The main task was to print all German-language periodical press and also official bulletins of a Reykhskomisar and general rulers, book-trade. There were many correspondents and photographers in their structure The societies "Press of Ukraine", "Ukrainiya", "Applied Press Ukraine" the "Agricultural publishing house of Ukraine" were subordinated to it.

The society "Press of Ukraine" was formed on December 1, 1941 by the same founders as "German Publishing Society". G. Grornauyer became the director. The society coordinated the work of all enterprises and printing houses in the "Reykhskomissariat of Ukraine" and in a zone of military authorities which controlled their economic activity. Provided with necessary materials, etc. Society "Ukrainiya" was also founded in Lutsk (November, 1941) by he National Union of the German publishers of newspapers in Berlin. At the beginning of 1943 this department of the press had the $32^{\text {nd }}$ own points of distribution. And in August of the same year periodicals had already extended in 65 cities.

In general at the beginning of 1943 society "Press of Ukraine" provided an issue of 91 newspapers with a general single circulation of about one million pieces. Thus, according to the estimates of the scientists investigating the occupational press in the territory of Ukraine there were about 300 issued newspapers and magazines (Черняков, 2006, 57-58). Permission to a such a number of periodicals can be explained with the aspiration of fascist administration to make completely control on information field of occupied territories, to distribute necessary propaganda character and thus to affect consciousness and behavior of the local population.

When in the summer of 1942 the Hitler's leadership understood that war would not end as quickly as they wanted. The press was used actively among the population and the periodicals became the major front in this case. Despite it, special methodical approaches that were used for the purpose of promotion among the Ukrainian population were developed for the edition of the occupational press. 
Staffing issue was equally important in the publication of the periodical press also. In the first months of occupation in newspapers and magazines the German administration employed mainly those Ukrainian journalists who in the period of the Soviet power government could not, for one reason or another circumstances to realize their professional and creative abilities.

The newspapers and magazines appearing in the occupied territory were issued in many languages. Most of them were given a circulation from 2.5 to 10,000 copies. The newspapers issued in the territory of Ukraine and zones of military authorities were issued mainly in Ukrainian, sometimes in Russian and language of the numerous ethnic minorities living during this period in Ukraine (Волковский, 2003, 207).

The majority of the newspapers and magazines issued in the occupied territory not too differed from each other according to contents and the nature of publications. On the first pages victorious reports from fronts and praise of the German soldiers were printed. The articles of the second and third pages published an information about the Bolshevist model and its hostile intentions on Ukrainian, about the famous Ukrainian figures of the past, about achievements of the Ukrainian peasants in the conditions of occupation mainly. The majority of reports presented through a prism of views of the German journalists or Ukrainian journalists cooperating with the occupying authorities. This fact formed a certain ideological and psychological mark of the reader.

Headings of articles in the "Volyn" and "Vinnytsia Messages Magazine" were the next: "Kyiv and Poltava are freed" (Волинь. Часопис для Волині 1941, 1), "Success on the Donetsk front" (Волинь. Часопис для Волині, 1942, 1), "Тhe German troops successfully constrain an enemy impact". In these articles it is said that the fascist army successfully had resisted to the Soviet troops in the northwest of the Kirovohrad region (Волинь. Часопис для Волині 1943, 1). It is interesting that those days - on November 23-24, 1941 - in the Soviet reports we can read that "the Soviet troops took the regional center of the Kirovohrad region, Onufriyevki. Around the lower watercourse Pripyat, continuing approach, they also occupied the regional center of the Polesia region with the city of Hoyniki" (Жадов 1978). What information was truthful? How did feel the population of occupied territories having obtained information from the German reports, at the same time and from Soviet?

Having glanced over occupational newspapers you are convinced that the allegedly fascist army really brought to the people of Ukraine peace and harmony. Opposite information was given in the Soviet press.

In the "Vinnitskiye Vesti" newspaper on the first page we read "Germany wins on all fronts" (Вінницькі вісті 1941, 1), on the second and third pages 
we see the publications "Awakening to New Life" (Вінницькі вісті 1941, 3), "The real face of the Bolshevism" (Вінницькі вісті 1942, 2), etc.

Most publications focused on differences in public administration in the USSR and during the German occupation. It was written in the "Sumskoy Vestnik" newspaper No. 6 of November 5, 1941: "The invincible German army brought to the city of Sumy the true freedom, having exempted it from a communistic yoke. Only recently citizens began to breathe a full breast..." (Сумський віник 1941, 2). The article headlined "Elimination of a Bolshevist Collective-farm System" there was noted that unlike Bolsheviks German the government had issued the order on granting the earth to peasants in individual use. It was published in the (New Ukraine, 6, 1942, 54-65). There it was told about difficuliest in life of the Ukrainian peasants and how thanks to "a New Order" and a "New Land Law", peasants would be able to become prosperous and would be able to provide "Great Germany State". However, it's known that the "Land Law" remained on paper. The collective-farm system continued to exist in another format. It was a very convenient form of managing in the conditions of which it was possible to control completely work of peasants and to withdraw the most part of the made products.

The press, first of all, carried out a strategic task of Nazi ideology to promote that the population of occupied territories stuck to anti-Semitic and anti-Bolshevist moods. So the important place was given to "Jewish question" in periodicals. Moreover, the Jewry was identified with the Bolshevism and the Soviet power (Вінницькі вісті. 1943, 3). In the "Vinnitskiye Vesti" newspaper of August 9, 1942, under the title "Real Face of the Bolshevism" it was represented a caricature which demonstrated how the Jew had removed the mask of Stalin. It was commented so way that Jews actively led the country and Stalin was their mask (Вінницькі вісті 1942, 3).

"Jewish question" occupied a prominent place in periodicals. In editorial articles as propaganda materials which prepared in Berlin the speeches and the reports of Nazi's leaders regularly had been published. The thought was accurately carried out that Jews as the support of the Bolshevist mode was the main enemy not only Germany but also other people of the USSR.

In addition to professional journalists, the authors of anti-Semitic and antiSoviet publications were historians, art critics, doctors, musicologists, etc. Practically all newspapers issued in the territory of Ukraine published special orders of the occupying authorities concerning Jews in a zone of military authorities on the last page of the edition. It was published also a huge amount of materials about the prosecution of Jews at all times and worldwide. The periodicals quoted from anti-Semitic sayings of the famous philosophers and politicians. Thus the ideological foundations of anti-Semitism were created on the territory of Ukraine. 
It should be noted that such publications especially appeared to be at the end of 1943 after the defeating of the fascist army near Stalingrad. The Hitler's government tried to convince the population of occupied territories that the Jewish people and the Bolshevist historically happened to become a threat and danger to humanity.

As soon as the occupied territory was given to German authorities, the process of publishing standardization and replacing of their owners began at once. In the first months of the Great Patriotic War a part of newspapers appeared at the time of the Soviet power continued submitting their censorship. This was explained by the fact that the Hitler leadership could not cancel periodicals in occupied territories because of disseminating information and messages.

Publishing activities in zones of military authorities was based on instructions of the Ministry of National Education and Propaganda. As an example we will consider a sample of one political directive concerning the press: "The Ukrainian and other newspapers issued in "Reykhskomissariat of Ukraine" - an exclusive tool for propaganda and administration policy. They do not serve national or cultural needs of the population or religion... Every line has to help with the implementation of a great mission of the "Fuhrer" in the creation of new Europe" (Косик 1998, 240-241). This directive is graphic evidence of functions of the German periodicals in Ukraine. There was no aim for any Ukrainian state or cultural aspirations.

The Germans treated very seriously the creation of a new network of mass media on the conquered lands. In particular it belonged to delivery of fresh information to Lviv at first by train from Berlin and Vienna then by the telegraph and finally across all territory of "Reyskomisariat of Ukraine2. Thereby the problem of providing all magazines with monotonous official information concerning events in Germany, in the world, on fronts and so forth was solved.

To run the press business a special "Press Service" was created in the Governorate-General territory. The chief of the press disposed to note that a state language in the territory of "Reyskomisariatu Ukraine" was to be German. There was separate publishing of official press in Ukrainian and Russian languages. The Nazi power adopted providing newspapers with necessary materials and the paper. The "Press Service" in "Reykhskomissariat of Ukraine" and in a zone of military authorities gave permission to the acquisition of the paper of each edition separately there. Printing houses could publish circulations only with the permission of the authorities too and it was possible to distribute only the editions allowed by the authorities.

So within a short period of time the beginning of the formation of information space seemed to become. The occupying authority conducted 
a policy of reduction of Ukrainian editions. Therefore within the first months the majority of publications ceased to leave in general. But already in 1942 newspapers were issued practically in each Governorate-General territories and almost in each area and the large city.

Periodicals in temporarily occupied territory became an important instrument of propaganda. It is possible to claim that the press played the leading role in the policy of the Hitler's government. The majority of newspapers in the territory of "Reykhskomissariatof Ukraine" were published on behalf of the local community. Local authorities had to resolve organizational issues of the press. Despite it all newspapers and magazines were under fixed control of censorship which was carried out by representatives of Wehrmacht propaganda structures and military authorities.

At the end of 1943 in the occupied territory of Ukraine, as it was noted above, about 300 newspapers and magazines were issued. The structure of each of these editions was also typical. So, if we revise several newspapers, such as "Ukrainian word", "New Ukrainian Word", "Volyn", "The Vinnytsia messages", "Kostopilsky News", published during 1941-1943, then we will see that the first page of these editions had aimed subject. On the first page the reports from fronts which moved in a pathos form on behalf of winners were printed. On the same page there was the review about the international events. It's interesting to note that information about allies and opponents was divided. For example, an Italy and Japan and the opponents as Great Britain, France, the USA and the Soviet Union. If it was talked about Great Britain or the USA authors of messages criticized practically all actions of the leaders of these states. If it was talked about Italy or Japan it was then said mainly about their achievements. Rather seldom on the first-page there was an information about the important events in the city or "Reykhskomissariat" or in a zone of military authorities. Generally such information was printed on the 3rd, $4^{\text {th }}$ pages along with usual announcements and orders of local authorities.

The second page of each printing edition is devoted to the fighting of the fascist army against Bolsheviks or military operations of allies of Germany in the South or in the Far East against Great Britain, France and the USA. There were too articles about the international events. They were often published international events in the world and caricatures of Churchill, Roosevelt, Stalin. The fourth page is devoted to the everyday's life of the population of the cities and villages. There the messages to a "gebits" and various nature of the announcement took place. It was reported about work of theatres, cinemas, the cultural chronicle, about the enrollment of children in school and their training. There were the articles devoted to sports subject. Considering informational content of the $4^{\text {th }}$ page, an impression was made that in the occupied Ukraine life rages at full 
speed and people were happy and joyful. The periodicals avoided giving information about all sorts of executions in the occupied territories, confiscation of housing and property, compulsory evacuation of youth to Germany, etc.

As confirmation consider a few several typical newspapers appearing in the territory occupied by Hitler's army, including the 88th issue of the "New Zaporizhia" newspaper of October 4, 1942. On the 3rd page we read the article titled "Education of Youth" where the author gave manuals as it was necessary to bring up and to educate young people of Ukraine on the examples of German youth. On the 4th page article titled "Cinema at This Time" it was told about with what pleasure the local population had got watching the German movies (Нове Запоріжжя, 1942, 3, 4).

In the 4th issue of the same newspaper of January 13, 1943 we read the message from the main apartment of the Fuhrer of January 9, 1943 about the victorious fight of the fascist army between the Caucasus and Don, in Stalingrad (Нове Запоріжжя, 1943, 1). Information was given from positions of winners. It caused the local population to believe of the hopelessness Red Army and its attempts to resist to troops of the Reich. In the message the achievements of the German army were shown and actions of the Red Army were humiliated. It was made with aim of demonstrating the destruction of the Soviet equipment or troops.

In the13th issue of the "Vinnitskiye Vesti" newspaper of September 28, 1941 on the first page there was a summary data of the fronts for September 26 and the message about fighting in the East from Kуіv (Вінницькі вісті, 1941) was given. It was important that the characteristic scheme of construction and arrangement of material should be in the periodicals. In the 14-th issue of the same newspaper of October 1 on the first page there was given a military construction till September 28, 1941. On the 2nd page of the same issue M. Ilyinsky wrote about the Jewish writers in Ukraine, on the $3^{\text {rd }}$ page there was the article titled "Awakening to New Life" in which the author told that process of revival of the Ukrainian culture would be promoted by German occupying authority and with its assistance the Ukrainian public organizations in which the Ukrainian population could fully realize the creative abilities. The fourth page is devoted to basic provisions of "An Order of Administration2 (self-government). The Second section headlined as "Spirit of Administration" was the most interesting It was noted that selfgovernment demanded that discipline, organization and worthy attitude should be obligatory and any free-minded position prevented restoration. The administration had to be guided by the idea of the Ukrainian people and the interests of the German armed forces. It was responsible for depriving of Bolshevist dissoluteness to return to national discipline and working rising. 
Further stated that the administration had had to care for that and to attract the people to the voluntary partnership, avoiding at the same time any coercion. "It was necessary that honest cooperation should be especially in branches of social, sanitary, cultural and sports work" (Вінницькі вісті, 1941, 1, 2, 3, 4). Similar installations to peasants were given by the Soviet authorities too. Actually Hitler's government created a regime of complete obedience to the laws and orders of the "Third Reich".

In the "Sumskoy Vestnik" newspaper editor clearly adhered to the structure of the coverage of events and the presentation of its position.

So in the first issue of this newspaper of October 19, 1941, on the 1st page, we read the address to the Ukrainian people under the heading "Joyful Time Came Big" where the author started to say about Ukraine with Taras Shevchenko's words. He told about how Ukraine was destroyed and led to death. "Big promises of free trade, of the full development of a private initiative, really free work, private ownership and full spiritual liberation promised by Bolshevic's power were not realized" (Сумський вісник, 1941, 1). On the $2^{\text {nd }}$ page of the 6th issue of the same newspaper there was given the article that the invincible German army brought to Sumy the true freedom, having exempted it from communistic domination and that "right now citizens began to breathe with a full breast and can be given peace" (Сумський віник, 1941, 2).

The newspaper "Novoye Ukrainskoye Slovo" issued in Kyiv was no an exception. The 229th issue of this newspaper of September 30, 1943, also completely corresponded to structural accents of creation of an information field in the occupational press. On the first page, as well as in the majority of newspapers, messages about successful fights of the German army near Zaporizhia and about big losses of the Soviet Army were given. There was an article titled "Guarantor of a Victory" where the author claimed that the Soviet Army had sought to take the whole of Europe and only intervention of Germany stopped "a red invasion". Hitler's Germany acted in this article as the guarantor of the peace in Europe. In September 1943 fascist troops receded under the pressure of the Soviet Army. Now the main objective of Hazi was to stay in occupied territories and to achieve the trust of the population. Therefore on the same page there was sent a message to the Ukrainian people that war would be coming closer again and the population have to help the German power (Центральний державний архів громадських об'єднань України, 1-2).

Through periodicals the German occupational regime created an illusion of a benevolent attitude of the Hitler's mode towards the Ukrainian population. Publications about constant underlining achievements and peaceful work for the sake of Great Germany and the publication how the 
Ukrainian culture blossomed and developed, constant comparison of the German regime with the Soviet one, of course, not in favor. A certain part of the Ukrainian society at first really trusted the occupying authority and cooperated with it.

From the very first days in all newspapers issued in "Reykhskomissariatof of Ukraine", mainly on 3-4 pages, it was told about work and achievements of the Ukrainian peasants. At the same time, it was noted that Ukrainian peasants would receive big crops and for this purpose and the German authorities would organize special agricultural courses to teach the Ukrainian peasantry

In the "Volyn magazine" of September 7, 1941, it was reported that with the assistance of the German power on the Ukrainian lands would have plentiful opportunities for the professional development of agricultural workers. In each area peasants should improve the technology of processing of the soil, increase in a number of cattle and improve the financial position (Волинь. Часопис для Волині, 1941, 3).

The old Soviet collective-farm system which the German occupying authority did not liquidate and placed to itself at service, even more often caused discontent. In this regard at the beginning of 1942 the occupying authority proclaimed reforms in the agrarian sector. On February 15, 1942 was reported the law "About New Agrarian System" was reported by the administration of agricultural industry. It was issued practically in all occupational periodicals on February 26. On pages of periodicals the broad campaign of promotion of the new "Land Law" and its provisions under the slogan "The earth to each peasant" was given. (Нестеренко, 2004, 282). It seems that reform has begun to act was far from the truth. The German occupational administration did everything to delay destructions of a collective-farm system.

Within two-three months in newspapers "The Temporary Charter of Work" detailed instructions on the organization of new land economy were lit. (Державний архів Сумської області, 1-10). An active discussion of the law created the illusion of its introduction. When peasants saw that really nothing shifts and they continued to work in collective farms, they began to oppose openly, warmed up by the Soviet propaganda.

In April-May, 1942 the occupational administration began to carry out the distribution of land and to issue the special documents certifying land ownership rights. But, according to officials of the economic headquarters "East" of May 18, 1942, peasants were dissatisfied that they had been forced to work in public economy system again. For them, it was the same collective farms. Even active propaganda about the advantages of this type of farms did not affect the moods of peasants. 
We find confirmation of these words in information message No. 7 of June 17, 1942, of the German retaliatory groups about the political situation in the areas which were temporarily occupied by fascist troops and in which the occupational administration noted that agrarian reform had been actively discussed generally among a rural population. At first, peasants were happy with the introduction of the new "Land Law" but interest in this subject fades, and the trust to local government had been lost. The author of the message concluded that "such situation made propaganda activity weak" (Центральний державний архів громадських об’єднань України, 27).

Next important question in periodicals was the culture and education of the Ukrainian population. Less often there were publications about scientific research.Considering the conceptual principles of the German policy on the cultural development of the population in East occupied territories, including Ukrainian, it should be noted that the administration of the "Third Reich" did not wish to encourage the development of national consciousness and national culture there. Himmler noted that education of the population in occupied territories could lead to disobedience. He stressed that "it does not correspond colonial policy of Nazi Germany" (Центральний державний архів громадських об'єднань України, 89). The policy of Hitler's regime in occupied territories came down to suspension of cultural development of Ukrainian and other people and to the destruction of their material and spiritual treasures.

But during the war when the German leaders understood that they were losing positions at the front, it was necessary to change the plans to gain trust and support of the local population and to force them to work for the fascist army. From that moment it was reasonable to influence thoughts and activity of civilians through culture.

Glancing over periodicals, almost in each newspaper on the 4th page we can see announcements of opening of the theatre, a premiere of this or that performance, demonstration of movies. So, in the "Volyn" magazine of January 1, 1942 we read the message about life in occupied territories: "In organized national theatre, of November 9, 1941, performing "Natalka Poltavka", "Nazar Stodolya", "May night". Also on the basis of the former theatre of miniatures in Kyiv, it has been organized "Cheerful theatre" where the performance "Green Island", Overchenko's "Torzhik" are given. The Kyiv theatre "Myuzik-hall" developed own repertoire which included dances and singing. (Волинь. Часопис для Волині 1942, 4). In the "Vinnitskiye Vesti" newspaper on which $4^{\text {th }}$ page advertises the opera in 3 actions "The Zaporozhets beyond the Danube" was performed (Вінницькі вісті, 1941, 4). And in the "New Zaporizhia" newspaper No. 88 for 1944 the author told about mass watching of German production 
movies by the Ukrainian audience and about impressions which were received by locals and esthetic pleasure, about the discussion which lasted after (Вінницькі вісті, 1941, 4). During an initial stage of occupation, the Ukrainian intellectuals were not evacuated. Having various reasons and circumstances they continued to work and support own people.

Working in educational institutions, teachers could influence pupils and their parents maintaining hope for the temporality of occupation. Others convinced the population for the German liberating mission. The most part of the intellectuals directed the activity of supporting Ukrainians to release from fascist aggressors, among them: O. Teliga, I. Rogach, O. Chemerinsky, V. Samchuk, I. Tiktor.

Analyzing the conditions of education in the occupied Ukrainian territory, it should be noted that Ukrainian children successfully studied at schools of the different directions: initial, four-class national, professional, the highest, etc. But actually, a considerable part of schools in Ukraine was closed in November 1941 and at the beginning of 1942. Only on Donbas, in the need of the qualified labours, the German administration supported the activity of craft vocational schools (Донецкий вестник 1942, 4). As the number of teachers sharply decreased (by "reliability"), and also the number of schools decreased (Донецкий вестник, 1942, 4).

From document No. 60 of separate orders of the department of army No. 34 of Wehrmacht, we see educational instructions in occupied territories regarding school policy in particular. It was said that according to order No. 30 of 08.12.41 pupils of primary school of national schools had been allowed to study. As far as higher educational institutions and schools they were forbidden: the universities, technical colleges, gymnasiums, lyceums and equivalent educational institutions (Косик, 1998, 368).

Despite it, it should be noted that in the periodic press it was constantly noted that Germany brought the European education on the Ukrainian lands, publications about opening and work of high comprehensive and vocational schools constantly were published in newspapers. So, we read in "The Donetsk bulletin" of November 15, 1941, that in Stalino since November 20, 1941, there were 9 schools (Донецкий вестник 1941, 4). In Artemivsk and vicinities, 14 schools were opened, but most of them were closed until the end of June 1942 (Бахмутский вестник, 1942, 4). In the "New Zaporizhia" newspaper No. 105 of 1942, it was reported about craft school where studied115 pupils and were taught mechanics, physics, technology and drawings (Нове Запоріжжя 1942, 4). In the "Volyn" newspaper of September 1, 1941, we read messages that from the beginning 1941-1942 academic year in Berdichev it would be opened gymnasiums for 
girls and boys separately. In addition, women's teacher's seminary had been organized (Волинь. Часопис для Волині 1941, 4).

About opening and running of primary and four-grade national schools was reported by "Putivlsky regional Department of Propaganda" and formation of the Sumy region. This report gave detailed information on applied improvements by the inspectorate and directors of schools. And in the report of educational institutions of Putivlsky district it was noted that since September 1942 started 46 elementary national school started to work. From them there were the forty-three in the countryside and 3 in the city of Putivl where studied 3797 pupils (Державний архів Сумської області, 6, 7).

It should be noted that in newspapers it was constantly told about education at schools and about what importance has it for Ukrainian. There were less students at most of the schools. If we consider the documents confirming the movement of children of school age, then we will see that, for example, in Deneshivsky national school of the Zhytomyr region at the end of September studied 385 pupils and already on January 11942 there were 203 pupils (Державний архів Житомирської області, 36). In ShpetskoBUDSKY elementary school at the end of September studied 70 pupils, and for December 1 of 1942 there were 57 pupils (Державний архів Житомирської області, 70). The reason was the next that because children were forced to throw school and to help parents somehow to live.

The administration issued instructions not to open a large number of schools and to close those which had been already worked. So in Rivne all schools were closed on November 14, 1941. It was explained by the shortage of fuel and in order to avoid the danger of spreading of infectious diseases caused by war (Волинь. Часопис для Волині 1941, 1). The requirement that in a class there were not less than $42-48$ pupils was another reason which actually restricted opening of schools. (Державний архів Житомирської області, 6) It is clear that such number of pupils could not be among the Ukrainian pupils so they were closed. There were some more reasons which interfered with work of educational institutions. It was lack of textbooks and insufficient quantity of notebooks and writing-materials, absence of libraries (Державний архів Житомирської області, 7-9). Here it should be noted that the Soviet textbooks were destroyed previously and new ones were not produced.

To support necessary moods among the population of occupied territories, the occupational administration constantly published in newspapers information on the activity of agricultural workers, about good harvests which are received by the Ukrainian peasants in collective farms, about the creation of various organizations and circles which helped the Ukrainian peasants to increase the 
cultural and professional level. In the "Volyn" newspaper of September 7, 1941, an article was printed. It covered activity of regional Land department of a district justice placed emphasis on labour productivity as fundamental principles of the welfare of the Ukrainian peasantry destroyed by Bolsheviks. It started the organization of "Rural Owner" community, in all areas (Волинь. Часопис для Волині 1941, 3). The regional department began an active promotion among the population of the Rivne region. From the first days of the activity there was published in the same newspaper that Ukraine was always the rich country and supported by the resources Europe. It was stated that Ukraine had everything to develop industry to be a separate and independent state. But the Bolshevist administration used the richness of Ukraine in their own interests. The collective farms created by Bolsheviks finally destroyed the Ukrainian village (Волинь. Часопис для Волині 1941, 3).

Rather effectively occupying authority used policy of withdrawal of the Soviet troops in the territory of the Ukrainian SSR. In articles it was told how roughly Soviet power destroyed crops, the plants and factories, mines, destroyed water supply systems and roads when receding and for this reason, it is so difficult to restore everything and to adjust normal life (Салата, 2005, 113-116). There were no difficulties for the German occupational administration to give this kind of information in newspapers for the local population. Actually, people saw what occurred during the withdrawal of Bolsheviks. In the "New Zaporizhia" newspaper No. 109, 1942 in article titled "Way to a Victory" the author wrote that Germans who had come to the Ukrainian land were struck with vandalism of Bolsheviks. The author focused the attention of readers that everything that was made and constructed by hands of peasants and workers. An iron, highways, bridges, crossings, the horse and motor transport, bakeries, bakeries, industrial and the enterprises were ruthlessly destroyed by Bolsheviks. The author called the Ukrainians to cooperate with the German administration and urged to undertake the recovery of the agricultural industry (Нове Запоріжжя 1942, 4). Unfortunately, many people witnessed such "activity" of the Soviet troops and therefore propaganda got positive.

For strengthening of propaganda among the population practically in all territories of "Reykhskomissariat" of Ukraine and in a zone of military authorities public and educational societies known as "Prosvita" and the "Union of the Ukrainian Writers" were created. Since October 1941 there were published messages that in the cities and the regional centres earlier operating societies "Prosvita" would have been opened. Readers got acquainted with the main aim of those societies and a plan of their activities. But the main thing what it is necessary to pay attention is that all societies 
were taken by occupational administration under the strict control and all activity completely either was regulated to a German administration or submitted to them. Actually occupational administration used society "Prosvita", as well as other public and educational organizations, for the dissemination of necessary information and for influence on the Ukrainian population. Despite strict control from the occupying authorities, most of the figures of "Education" sought to awake national consciousness and help to survive under critical conditions. One of the first societies "Prosvita" began to act in Vinnica. In October 1941 local society was created. It was told that it was made for strengthening national consciousness of Ukrainian and for development of the members, to give them good knowledge, to help to assert the civil and national rights, to teach to spend substantially the time. Among tasks which society "Prosvita" set for itself there were such:

- to open libraries, bookstores, reading;

- organise public readings, lectures, reports, conversations;

- to publish books, newspapers and leaflets for ordinary citizens;

- to create schools for adults and children;

- to open children's communities;

- to organize evenings, Christmas Eves. (Вінницькі вісті 1941, 2).

The same society worked also in the territory of Kharkiv. In February 1942 in the draft copy of the protocol of board of the Kharkiv society "Prosvita" we read about acceptance of citizens in the list of society members and about the estimate approval. It was also accepted the Charter and definite purposes and tasks for work among the population (Державний Архів Харківської області, 1-3).

On January 3, 1942 the meeting of Council of "Prosvita" in Lyubomla was held. It accepted the resolution about new organizational forms and methods. During this period some sections began to work. They were of different directions as the cultural, educational, youth and female section. Besides it was made a decision to create "Public Court of Honour" which should be coordinated by a Chairman of "Prosvita" society (Волинь. Часопис для Волині, 1942, 3).

The activity of "Prosvita" was completely regulated. Its activity demonstrated in administrational messages from local communities in Kyiv. It is noted that "Prosvita" bore responsibility for the local activity of societies and developing it only according to the directions which would be formed by the local administration. Without permission of occupational administration no one society could be created in the area. Unauthorized societies were considered to have been illegal organizations. Also, it was noted that 
"the organizational scheme, as well as democratic methods and bases of societies "Prosvita" will be changed and adapted for modern requirements" (Волинь. Часопис для Волині 1942, 4).

In Kyiv the theatre's repertoire was developed in on the initiative of the "Prosvita" office. It included dances and songs, small representations (Волинь. Часопис для Волині 1942, 4). In Kyiv "Department of propaganda" the "Union of the Ukrainian Writers" was founded. At the disposal of Department there were all culture authorities of the city as the periodicals, cinemas, theatres and radio. Elena Teliga headed the "Union". Boris Vinnitsky and Ivan Irlyavsky entered it also. The "Union" set the task to unite all Ukrainian writers and to direct their creative activity in favour of the Ukrainian national culture. Own publishing house "Kultura" was created, It prepared a series of literary and publicistic works. With the assistance of the "Union" for the third day after Hitler's troops captured Kyiv, the diary "Ukrainian Word" began to appear. Since October 19, 1941 seemed to issue the literary supplement "Literatura I Iskusstvo" which was compound the "Ukrainskoye Slovo" magazine (Волинь. Часопис для Волині, 1941, 4). O. Teliga made a lot for the activity of the Union and the edition of the "Ukrainskoye Slovo" newspaper. After the arrest of an edition of "Ukrainskoye Slovo" she did not take the resolution of the German power into account and continued to defend the position ignoreing instructions of Germans provocatively and essentially.

Periodicals gave an opportunity to the population of occupied territories to monitor the activity of societies "Prosvita" and, at first sight, the picture developed very well: as if Ukrainians had an opportunity to realize all the talents and abilities to develop national culture and to realize the national idea. But actually, as it was already noted above, all activity of this organization was controlled tightly: printing editions which appeared were exposed to strict censorship, library stocks were formed according to requirements of the new government, performances and evenings were held on the specified subjects and contents, etc.

The problems concerning a cultural life were brightly covered on pages of the occupational press. It can be explained with the fact that the occupying authority sought to gain trust among the local population, especially Ukrainian intellectuals which remained in occupied territories.

Through the press, the occupational administration tried to influence also youth and its education. A set of newspapers devoted the pages to units for the education of younger generation Ukrainian. In the Volhynia territory the newspaper "Information service" began to publish. On its pages much attention was paid to the education of youth and questions of culture. In one of 
the issues of this newspaper, it is told that the Ukrainian men and women who visited Germany and saw the high level of culture would try to be wellmannered, cultural people if they wanedt to develop their. "It is necessary to send Ukrainian youth to Germany where it will be grown up in such conditions". The author of article urged to send every Ukrainian to Germany where they would see the beauty of the "Reich" and get a knowledge and speciality which would be so necessary for the development of their own state (Державний архів Рівненської області, 5).

In the "Vinnitskiye Vesti" newspaper activity of the Ukrainian National Student's Union of the Vinnytsia (SUOS)" is propagandized and emphasized that "it is the only youth organization capable to deal with various problem tasks facing the nation and its youth during the war. The main objective of this organization is the education of the Ukrainian youth in the spirit of the fight for statehood against remnants of slave spirit among individuals" (Вінницькі вісті, 1941, 4).

Newspapers printed not only articles but also propaganda pictures and video records which were prepared by the Ministry of National Education of Promotion. On the picturesque landscapes were shown the Ukrainians working in Germany. They were well dressed, smiling, happy, working with pleasure behind machines. It was shown how they had a rest after a day of work. Letters of the Ukrainian workers published from Germany with certain comments called for join them and other young people for the sake of the future of Ukraine (Гальчак, 2004, 57).

Materials of the majority of newspapers about the good life of Ukrainian population under the German occupation were prepared in advance. Authorized representatives, travelling on "Reykhskomissariat" took pictures of the best corners of the Ukrainian nature, indicative work of peasants and all this placed in Nazi newspapers in Germany in newspapers which were issued in the occupied territory. These pictures had to convince the population of Germany and Ukrainian that the Hitler's power really brought on the Ukrainian lands freedom and welfare (Центральний державний архів вищих органів влади та управління України, 40).

Exposing people in the USSR became a widespread subject in the local periodical press. In the "Podilya" newspaper which appeared in KamyanetsPodilsky it was published the feuilleton "About Ivan Ivanov", articles "Soviet Paradise", "Picture of Streets from Moscow" where in comic style there was told about the life of the population of the Soviet Union.

The message was published in the same newspaper in which the Ukrainian committee of Kamyanets-Podilsky urged to offer money for the families of scientists who were killed or deported by the Soviet government 
(Центральний державний архів вищих органів влади та управління України, 11-12).

One of the departments of East Occupied Territories was engaged in the production of pictures about the life workers and peasants in Germany. They intended for use in the German periodicals for the population of Germany and also in the newspapers issued in Russian for residents of temporarily occupied areas of the USSR. Among them there were pictures of the working industrial enterprises standing at machines and showing products which they made and the peasants who were working with pleasure at the wheat field and spending leisure-time: reading books, playing soccer, celebrating birthdays among the friends, etc. (Державний Російський воєнний архів, 7-24).

Actually, it was not so easy for the Ukrainians to work in Germany. Everything depended on two important factors: places and the owner. From testimonies of the Reich Minister of Arms and Ammunition A. Speer we can study how they forcibly transported workers from all occupied countries and distributed on the enterprises and in what awful conditions they had to work. Those who violated working conditions were sent to concentration camps (Допрос подсудимого Шпеера 1946). In the resident's memoirs of the Vinogradnoye village (Murovanokurilovetsky Region, Vinnytsia region) who were taken out for work to Germany shown that conditions of accommodation were extremely heavy and inhuman. The camp where they lived was enclosed with a four meter fence connected to the power supply network so that workers did not run away. The people were fed very badly moreover and constantly beaten. Fascist security guards noticed: "You are not people you are cattle. Faster you will die, better would be for you and for us". Also workers from Ukraine were dying daily. They were dumped in a hole which was often forgotten even to be estimated (Державний архів Вінницької області, 7).

The same memoirs of the Nemirovsky Region of Vinnytsia region told that they "lived in Stuttgart, in the barrack where placed 12 people because none of the owners hired them". There stayed for 6 months. Food was very poor: in the morning - the 2 nd swede and 1 cup of tea, in the afternoon bread "brick" for 10 people. Children who constantly were ill had been visited by the doctor and after sent back home" (Державний архів Вінницької області, 724).

During the first period of the Great Patriotic War, the recruiting campaign still was somehow conducted. But already at the beginning of 1942 it was almost impossible to send voluntarily from youth or mature age to Germany. Therefore newspaper became one of the most important form of propaganda towards departure for work to this country. 
Caricatures became a very effective instrument of dissemination of necessary information.

In T. Lawson and D. Gerrod's Dictionary reference it is one of media images which reproduced culture and society through mass media and led to the creation of stereotypes (Лисенко, 1998, 218). It was a genre of the fine arts of the main form of graphic satire. It had an accurate social and critical or political orientation.

By the beginning of World War II, there were already two types of political caricatures: caricatures of active perception and caricature of passive perception. The caricatures of active perception provided a rich imagination of the prepared reader and saving freedom of interpretation to it through depersonification of heroes. But the population of occupied territories had been in special conditions. Firstly, under pressure of Bolshevist and then the Hitler's information attack. The German occupational administration used caricatures of passive perception which did not demand a special reflection over the image. There was no opportunity to interpret a caricature in own way because it was followed by a determined inscription. It imposed others opinion in advance. The caricature took the important place not only in newspapers but also in leaflets, brochures (Стернин, 1970, 428).

As it was already noted above, caricatures often placed on pages of the regional newspapers "Svobodna Ukrainf", "Volyn", "Golos Volyni", "Gazeta Horlivka", "Donetsky vestnik" and others. So, for example, in the "Vinnitskiye Vesti" newspaper for 1941-1942 almost in each issue there was a political caricature of Stalin and his administration. In newspaper No. 43 of May 31, 1942, a political caricature, on Stalin and Churchill who in a team carry Roosevelt and under the image there was the text "Step by step. The "lord of a lie2 Churchill to Stalin's father: 2My dear Stalin, a year ago I sat on goats and invited you to sit down2 (Вінницькі вісті, 1942, 3). Authors of a caricature tried to distort the relations between three Presidents and to show to the population of occupied territories that these three leaders who made among themselves the agreement did not worth attention.

In September 1942 amount of caricatures increased. On the pages of occupational newspapers one more interesting caricature was placed with headline Liars at the microphone. It represented three Presidents at the microphone with the text "U.S. President Roosevelt: "Our purpose is a freedom”. Britain Prime Minister Churchill: “... and everlasting peace!”. Father Stalin: “... and the Soviet paradise” (Вінницькі вісті, 1942, 2).

In October 1943 the army of Wehrmacht was forced to conduct defensive actions and to recede on the West. It tried to take away industrial and agricultural property from Ukraine and to take out people. The caricatures 
published in newspapers seemed to have been of other character. They showed attractive to Bolsheviks Ukraine "which was being saved by the German army” (Волинь. Часопис для Волині, 1943, 2).

Really caricatures impacted on the population of occupied territories and made everyone Ukrainian be in a state of a big impression. They forced to think over the situation which developed at that time. Often, to share an impression, the Ukrainian citizens paid $t$ attention to this or that caricature, again and again, discussing it, giving it new sense.

The periodical press was an effective remedy of propaganda. But even the Hitler's administration which used huge material resources to print and to extend the circulation of occupational newspapers, could not capture all population of occupied territories of the USSR. Not often periodical press got to the Ukrainian villages. Therefore the local administration was forced to organize conversations about the situation on fronts and a new land reform and many other questions. About these problems we learn from the Information message of the German Retaliatory Divisions No. 48. The message was dealt with an economic and a political situation in temporarily occupied territories in April-May, 1943. The document demanded that the periodic press and book should observe among the local population and arouse the interest to daily news especially from the occupied territories. Providing with the press was very bad because of the delivery problems. In this regard, the administration decided to start regular speeches of local commissioners and heads who carried out political informing (Центральний державний архів громадських об'єднань України, 7).

From the message of the German Retaliatory Divisions No. 32, we have got and analysed information how Zhytomyr commissariat had compensated a small number of newspapers because the local population wished to get news and read those newspapers with a great interest. The Commissariat offered that "broadcasting should be about the latest news only in Ukrainian at least in market days. It was even made the map of a warlike situation tagged with fights of the fascist army" (Центральний державний архів громадських об'єднань України, 21).

Except for periodicals on Reykhskomissariat's territory various literature delivered for the population. Books from fascist Germany were distributed in the libraries which still remained in reading rooms opened in the cities for the purpose of dissemination of necessary information. Actually, they became the centres of propaganda.

Thus, the German occupational administration set periodicals to the first place with the purpose to create information space. It applied various forms of propaganda by issuing newspapers and magazines in Ukrainian; showing 
movie theatres; releasing evident propaganda in the form of posters and leaflets and also documentary exhibitions; through theatrical performances, broadcasts in Ukrainian, Russian and other languages. It was all modern methods of using the press in war conditions.

The population of temporarily occupied territories of the USSR demanded news as the only opportunity to be guided in those difficult conditions. For this reason, the Hitler's administration used the press as one of the effective tools applied not only on the mind but also on the consciousness of the population of temporarily occupied territories. The German occupying authority tried to use the information hunger reigning after the temporary withdrawal of the Soviet troops and to fill the information vacuum with own propaganda. For this purpose, almost in each area the city newspapers and magazines were issued. In the rural zone where newspapers extended, arranged limited special boards where they hung out separate releases with comments of local authorities.

One of the components of information space in occupied territories were radio and film promotion propaganda. Radio, as well as periodicals, treated on the consciousness of the person and in the conditions of war - on troops and the population of the enemy. The analysis of properties of radio technologies which has been carried out by the famous Russian scientists V.L. Petrov, S.M. Sholokhov and A.V. Snegurovim demonstrates that radio was rather powerful information weapon. It was many-sided on the nature of the manifestation (Петров, Шолохо, Снегуров, 2001, 60-66). In 30-40th years of the 20th century radio and television were still insufficiently developed but their influence was powerful.

Radio and television were considered to be more easy for perception by the person rather than printing promotion. It is important that it should perceive not only through judgment but also aurally and visually. For this reason as technological tools of information weapon they quickly strike consciousness of the person and destroy ways and forms of its identification on own societies.

From the beginning of World War II of 1939 methods of radio propaganda and promotion were developed and improved. Then a radio favourably differed in the fact that it easily overcame borders of the states and worked instantly. Radio propaganda became the integral element of military tactics and the strategy of Nazi Germany where psychological processing of the population preceded before military operations. This technology was adopted by the majority of the European countries as opponents of Germany. So, Great Britain, having conceded in war ought to at once organize broadcastings abroad in German. Also it was done by the United States of America. There 
were different types of radio stations and types of propaganda corresponding to them. Among them "white" radio propaganda stations were officially registered. They transferred the authentic but thinly picked up for the solution of specific objectives information. Another type known as "grey", as a rule, it was official station which used as the checked, reliable, and unchecked, unreliable information: rumours, conjectures, etc. As far as "black" underground stations they transferred frankly false information misinforming the population, committed information diversions. Often "black" stations were conducted by means of the transmitters installed on cars which moved along the border of the state to which it is sent "black" broadcastings or along the front line. Quite often the ships which plied in neutral waters acted as carriers of transmitters of "black" radio stations. Both "white" and "grey", and "black" were used by the conflicting countries (Шариков, 2008, 514).

Thus, already today we have to understand that radio and television as information weapon became an important factor in the war of Hitler's Germany against Britain, France, the USA and against the Soviet Union during 1941-1944.

Seeking to capture as it is a possible large audience, the fascism adopted the new, still a little developed communicative technology as radio. Thanks to new technology, dissemination of information, activity covered broad masses of the population that the most important, at the same time kept the most effective method of communication as an oral speech. Loudspeakers were installed at restaurants, at the plants, in public places (Jowett G., O'Donell, 1992, 187).

Germany had experience of maintaining radio war at the sea even during World War I. It rather effectively influenced the fleet and troops of enemies. Thus during an initial stage of war Nazi Germany fixed big advantages over the enemies. Not only radio as military technology but also radio and television as public communications actively were developed in the interwar period in Germany. Broadcastings occurred not only within Germany but also for the European community in what the German radio had already certain experience.

Since 1929 in Vusterkhauzen, near Berlin, "German Wave" which problem was preparation of broadcast for the Germans living outside Germany began to broadcast the transmissions. After the fascist revolution in 1933, this activity assumed an extremely wide. During the same period the government institution known as "The German broadcasting society" was created with Department of Foreign Countries Broadcasting". At the disposal of Hitler and Ministry of National Education and Propaganda headed by Joseph Goebbels there was one of the most modern radio station in the world. 
From Konigsberg it was possible to conduct broadcasts to Poland and from Hamburg and Bremen to Great Britain, from Stuttgart, Frankfurt - am-Main and Saarbruecken to France and other European countries (Энциклопедия третьего рейха, 1996, 387).

Opened in April 1933 transferring of broadcast radio to North America where at that time there was rather powerful German diaspora which had about 10 million People (Международный интернет-журнал "Русский глобус", 2004) became one of the most powerful activities of the German radio.

During the period from 1933 to 1939 German broadcastings extended to Africa, Latin America, East and Southern Asia, Central America, Brazil and the Arab world. By the beginning of World War II Nazis conducted broadcast round the clock for 8 regions in seven languages. Their average daily volume was equal to 75 hours (Радиожурналистика, 2000).

Extending broadcastings to foreign countries fascist promotion sought to reach such popularity which would allow it to compete with mass media of these countries and broadcasts of foreign states. Almost all programs of Nazi promotion were focused first of all on consolidation of ethnic Germans abroad. The significant role was played by broadcast which propagandized the greatest mission of Germany.

Having secured European radio space, the propaganda headquarters of Hitler began the real radio war in Europe. As one of striking examples aggression against Austria could show that fact. Motivating ethnic unity between the German and Austrian people existing for a long historical period the Austrian earth was considered to be a part of the German living space. The Nazi leadership of Germany began an active radio propaganda against the government of Austria. It was ended by the entrance of the German troops on its territory. The powerful propaganda campaign was conducted as well against Czechoslovakia. The propaganda directed against the Slavic people was the main maintenance and the direction of these broadcasts.

Poland became the following subject of Nazi political propaganda. The information war against this country began in January 1939. The Polish government was accused that it threatened Germany and rendered pressure on German ethnic minority. Exactly here the radio also played an important role. On September 1 Nazi radio distributed the false version about an invasion of Poles to the German territory having declared aspiration of the German government to the peaceful resolution of the German-Polish conflict (Радиожурналистика, 2000).

Such activity of the fascist government of Germany demonstrates that carrying out provocations, shifting responsibility for the aggression to other 
countries. That's no doubt that radio propaganda promotion played a very important role and became the effective tool of Nazi policy.

Information weapon of broadcasting became not less powerful also in the territory of Germany. It was one of the main mechanisms of the formation of information space of the "Third Reich".

A special attention in the broadcasting of the 30th years was paid to the organization of the audience. Nazis organized the all-German campaign under the slogan "Each Citizen of the Country - the Radio Listener". The active work on collective listening to radio programs in public places and at the enterprises was conducted. Drastic measures were taken to save Germans from foreign broadcasting. For this purpose since 1933 new types of receivers for collective listening were begun to release "the national receiver" and "the receiver of the German popular front". Those devices did not allow to accept foreign stations. The receiver intended for mass listening was known to appea for the first time that year in Germany under the name "Kamerad". It could serve the audience up to 500 people. Special short-wave receivers were released only by two firms called "Telefunken" and "AEG". They intended as it was specified in the advertising price list "for the Germans who are located abroad" (Радиовещание в Третьем Рейхе, 2009).

Right after coming to power the Nazi leadership, as well as all other mass media placed radio to themselves at service. According to the decree of September 22, 1933, the "Imperial Chamber of Culture" was created. It was under control of the Ministry of National Education and Propaganda. It consisted of seven departments such as press, broadcasting, cinematography, theatre, literature, music and fine arts. Membership in one of those chambers was obligatory for each creative specialist of Germany. Any creative activity without the existence of the relevant member documents was punished by the Nazi authorities, up to imprisonment.

Radio and cinemas, as well as the press, quickly became the major tools and levers on the population having placed at service to the state. Goebbels considered radio and later television as the main tools of propaganda in the modern society. Through the Department of Radio of the Ministry of National Education and Propaganda and through the Chamber of Broadcasting it was established a complete control forming such contents of the program on the radio. It helped with the achievement of the Nazi purposes to adapt their contents for the ordinary listener.

It should be mentioned that the task was solved successfully due to the fact that the state had a monopoly on broadcastingwas as in Germany so in other of Europe. In 1933 Nazi government became the owner of broadcasting corporation of the Reich (Ширер, 1991, 279-280). 
The cinema remained in the hands of private companies but the Ministry of National Education and Propaganda and Chamber of Cinema controlled all aspects of film production. They set the task to remove the film industry from the sphere of liberal and economic ideas and to allow it to carry out the tasks assigned to it by the National Socialist Party and the Nazi government. In the middle of 1936 cinema was subordinated to the Ministry of National Education and Propaganda of Germany. The film industry completely passed under control of the state and began to be financed by the National-Socialist government (Ширер, 1991, 281-282). In both cases the identical result was achieved. As a result an empty radio programs and movies were offered the German people.

Hitler turned well-developed mass media as the instrument of propaganda. From all media which influenced masses, Hitler preferred radio. By means of broadcasting, the Nazi government carried out reorganization in the consciousness of many Germans. For quite a short term Nazis turned the most part of the population into the followers.

Character and extreme effectiveness of Nazi propaganda at that time was the fact that Goebbels before others analysed possibilities of scientific and technical progress in the field of media and communication, including propaganda opportunities of radio. In Germany of the 20-30th years of 65000000 population, 26000000 listened to the radio. In the country, despite the crisis, there was one of the world's best networks of radio stations: 10 main transmitters and 15 auxiliaries. Radio conveyed information including propaganda of NSDAP. In all corners of the country and, thanks to low cost and availability, it was much more effective even than the press. It was only necessary to provide penetration on radio. Disinformation of the population seemed to give automatically. It existed on a national socialist information background receiving an ideological interpretation of any events necessary to the National Socialist Party which took place in Germany and in the world. After 1933 the Minister of Promotion of the "Third Reich" Goebbels recognized the force of the radio: "Our descendants will be forced to note that the radio as means of spiritual impact on masses was the same value presently, as to the Reformation the invention of the press. It is possible, without being afraid of an exaggeration, to tell that if there was no radio and planes, then the German revolution could not take place in such form as it сате" (Киевский телеграф, 2005).

With coming to power of the National Socialist Party the control of work of the German radio stations was entrusted to Y. Goebbels.

In March 1933 Goebbels transferred national broadcasting from under guardianship of the "Head Post Department" to submission of the Ministry of 140 
National Education and Propaganda. Work of the German radio stations was rather carefully controlled personally by Goebbels. At the head of Imperial radio chamber which was a part of the Ministry of National Education and Propaganda as administration, he appointed Euzhen Hadamovsky who got down to business transformations of radio to the effective instrument of Nazi propaganda not only in Germany and Europe but also in occupied territories.

One more public authority directly was engaged in broadcasting in East occupied territories. It was a Ministry of East Occupied Territories. Within the directions of the activity departments were engaged in propaganda activity and creation of broadcast for the East which were broadcast through Radio named "Vostok Radio" station. The staff of departments formed short reports, comments, debates, etc. (Державний Російський воєнний архів, 1).

Listening to foreign radio in the territory of Germany without the permission of the Information Bureau of Germany was strictly forbidden. Information bureau controlled this process and gave permissions to the listening of foreign broadcast to individuals (Державний Російський воєнний архів, 27-35). The ministry of East occupied territories prescribed punishment for listening to foreign broadcasts without special permission. To avoid mistakes and to strengthen control of propaganda by the department it was made the list of persons and firms which already got such permissions (Державний Російський воєнний архів, 17-23, 48-54).

Under the leadership of Goebbels broadcasting in Nazi Germany was controlled and extended three divisions: leadership of the Nazi party, Ministry of National Education and Propaganda and Department of Culture of the "Reich". 26 radio stations represented institute of the all-German broadcasting known as "Big German radio". Political programs and speeches of the "Fuhrer" went synchronously on all stations (Энциклопедия третьего рейха, 1996, 388).

Providing broadcast the Ministry at the beginning of World War II the Ministry of National Education and Propaganda developed the project of creation of a transmitting centre which power would reach $1000 \mathrm{~kW}$. But in connection with the shortage of financing and rather a capacious process of production those plans were not carried out. But at the beginning of war 6 long-wave and 10 mediumwave motorized stations of the facilitated type on $20 \mathrm{~kW}$ were created (Жолквер-Краснопольской). These stations were rather mobile, They were easy to be thrown by rail in occupied territories or to areas of the front. The fact that they could be dismantled quickly was positive. It was possible to collect for 2:00. Such mobile radio stations were used in the occupied territory of Ukraine. 
With the attack of Germany on the USSR, the German radio cardinally changed into the military direction of the work. From now on the main place by air a block of political and military programs was taken Since 1940 the Soldier's Voice broadcast began to leave. It was created a special information and political program about war events on fronts which were called "Spot news". There was one more program later. It is called as "The Message from the Front". Broadcast of its messages went straight in the air from planes when the cities of Britain were bombed from the advanced parts of the German troops entered on the territory of other countries.

Having entered on the territory of the USSR, troops of "Wehrmacht" understood that radio propaganda at this stage was almost impossible as the Soviet power confiscated all radio receiver devices from the population. The German newspaper titled "Nakhtausgabe" of March 11, 1942, in the article headlined "Low Level of the Soviet Radio" noted that in the Soviet Union radio had been a very poorly developed. There were only 350000 radio sets on 170 million population (Державний Російський воєнний архів, фонд, 34).

The leadership of Hitler's Germany had to create a new network of powerful broadcasting centres and to adjust broadcastings in occupied territories. It was created the Ukraine radio group whose main transmitter was in Vinnytsia. By November 1941 in Ukraine there were 7 radio stations. Subsequently the number of radio stations increased to 15 .

Thus, practically in each settlement radio transmitters which informed the local population on the current events and new directives were located. (Окороков, 2007, 44).

The advisor of the East department of the Ministry of National Education and Propaganda doctor Taubert in the report noted that in occupied territories it was necessary to create a radio network with the centre in Berlin. For its effective work he proposed it was necessary to unite the work of a staff of radio and heads of the group. "To recruit whenever possible such employees from among local population was to involve them in cooperation" (Федеральний архів Німеччини, 55). This report proved the fact that that the majority of broadcast which East department of the Ministry of national education and propaganda sent to the East was generally aimed to the German soldiers and the population of the occupied eastern territories. Broadcast for the population was being conducted in the Russian, Ukrainian, Belarusian, Lithuanian, Latvian and Estonian languages. The majority of messages arrived directly from Berlin. It was caused by the need of fast transfer of various information as orders, directives, resolutions and urgent messages for coordination of control of the population at the occupied eastern territories and implementation of necessary actions (Федеральний архів Німеччини, 56). 
Propagating the political goals and military aspiration among the population of occupied territories of the USSR the German occupying authority paid much attention to broadcasting as means of dissemination and the instrument of control. At the beginning of 1942 the Supreme Command of the fascist army sent the special operation manual of radio under title "The Organization of Hearing of Broadcasts in the Occupied East Areas" to troops of Wehrmacht. In it it was noted that the German troops which had involved in the military operations in the East and also the occupied areas which were in the rear had to understand how important for further warfare would have been the coverage of all population with political propaganda. It was noted including the fact that all technical equipment which was in military units at that time and was not used for the duty purposes could have to be used for propaganda (Юденков, 1971, 71).

At the Ministry of East Occupied Territories the sections which were responsible for propaganda were created. They were carried out in various directions. Among them there was the "Department of Group $18^{\text {th }}$ " which was responsible for work of cinema and radio in occupied territories of the USSR. Among its main objectives of the Department, there was a submission to the interests of Hitler's Germany of cinema and radio for eastward propaganda. Demonstration of week reviews, display of short films, propaganda, educational and documentaries was planned. Through a radio network planned to broadcast news, reports, temporary events and other broadcast. Also, musical funds of propaganda were raised. To powers of this department control and supervision of cinema, radio, theatres, etc. (Державний Російський воєнний архів, 39).

The similar department of "Group 18" of the same Ministry which directed by doctor Goyenstein had a political focus. Its functions were the regulation of radio and cinema to the political course, the organization of programs of special maintenance, control of secret radio stations, care of the equipment and control and the management on the central society of cinema of the East (Державний Російський воєнний архів, 42).

All materials which arrived on radio had to be transferred to "Reykhskomissariat's territory" and other territories occupied by the German army. Underwent political processing in the Department of Propaganda of the Ministry of East Occupied territories (Державний Російський воєнний архів, 12). broadcasting of "Radio East", in particular for "Reykhskomissariat of Ukraine", was prepared in two language Russian and Ukrainian.Daily 14 Russian, 14 Ukrainian broadcast came out. They consisted of news, short reports, comments and pieces of music (Державний Російський воєнний архів, 2). 
From the correspondence of the Ministry of National Education and Propaganda and the Ministry of Foreign Affairs of Germany it was studied which attention was paid by the Hitler's administration on the radio as to one of the main instruments of formation of information space. Both branches of power were also involved in forming up programs for occupied territories of the Soviet Union. Together with the Ministry of East Occupied Territories they developed the programs directed to discredit of the Soviet government and military authorities of the USSR, for obtaining favour of local population (Державний Російський воєнний архів, 90, 15-27).

Already during the Great Patriotic War technological achievements of broadcasting were used not only the Nazi but also Britain, the USA and the USSR. A famous American intelligence agent P. Laynbardzher who investigated features of the psychological war came to the conclusion that the German radio propaganda had been carried out by means of specially developed receptions and methods. Among them he called the following: official reports in which favourable news obtained in details and unfavourable. They were the next to have worked as methods: superficial; repetition of official reports of the opponent with a definite propaganda purpose to undermine belief in success of the opponent; sensational broadcast in which the attention focuses on one important subject or an event; transfer of absolutely counterfeited materials, that is fictional what listeners can understand not at once; transfer of official programs or with reference to fictional sources and also such broadcast based on information source which is secretly controlled by Germany, etc. (Волковский, 2003).

In instructions on propaganda application according to the plan Barbarossa it was noted that loudspeakers should be used not only to impact on the military of "Wehrmacht" but also for the population of occupied territories (Волковский, 2003).

To influence the population of occupied territories with more force, the Hitler's government created the system of "black" radio stations. In 1942 one of such radio stations sounded for the population of occupied territories of the USSR on behalf of "Old Lenin Guard" (Орлов, 1985, 133, 134).

With the arrival of the fascist army on the territory of Ukraine all radio receivers were confiscated from local population. And though how many the administration of occupied territories did not speak about freedom of the social and political relations in occupied territories, the fact that it was forbidden to have radio receivers and furthermore to listen broadcasts of other countries, especially Soviet radio stations, testified to true their intentions concerning to the Ukrainian people. A luminescence of such policy was the case occurred on January 17, 1942. The sentence of the Velikooleksandrivsky 144 
commissioner in which Alexander Sosnovsky who listened to Soviet broadcasts on the radio receiver designed independently (Немецкофашистский оккупационный режим (1941-1944 гг.), 1965, 75). It was also forbidden to read and distribute information from the Soviet newspapers, through guerrillas fell into hands of the local population.

Radio programming schedule of the German radio stations prepared for the population of occupied territories was standard. So, for example, if to consider the program of a radio station of "Vinnytsia" for a week from October 5 to October 10, 1941, we can see that actually overview of events being happened in "Reykhskomissariat of Ukraine" took place in the same time. The messages were transferred in German but music, poetry and prose were more prime time. Broadcast continued from 12 o'clock and till 14 o'clock. Music programs alternated with short news and messages of local occupational administration. In separate days there were economic messages in German and the sowing calendar generally for ethnic Germans. From 16 o'clock and till late on radio evening there was classical music. The Ukrainian poetry and prose, the Ukrainian songs were sounded. Periodically changing short news were broadcast in Ukrainian and German languages and survey of the press in German. On the weekend for local population music programs where it was possible to hear the Ukrainian chorus, symphonic orchestra and brass bands, arias of the Ukrainian operas were broadcast too (Ведєнєєв 2003, 4). Thus, the German occupational administration minimized informing the local population. For Ukrainian there was information on achievements of the German army on fronts and the orders of local administration and music programs.

From the first days of occupation the German military authorities organized continuous or incidental broadcastings in the cities and settlements. For example, the "Vinnytsia Broadcasting Centre" had began to broadcast since August 5, 1941. The first day of the work it was began with the German march from 4 loudspeakers equipped on the Ukrainian avenue having notified the population of the city. The majority of broadcasting centres of Vinnytsia region, as well as in other areas of Ukraine, was destroyed during withdrawal of the Soviet Army. In a year $161.65 \mathrm{~km}$ of a radio network was repaired. It was included 3.095 receivers. 809 loudspeakers were repaired, 1087 damages of a radio network were (Вінницькі вісті, 1941, 3).

With the arrival of the fascist army and introduction of the occupational mode in Kyiv the so-called "Sector of Information" was created. The main task of that branch of informational power was to "Sectors..." collect data in the field of public opinion of the city. That authority collected an information about the response of people to actions of the power and the illumination of 
news about work of city institutions. It was important that administration of the "Sector of Information" should be informed about people and their life, structure of authorities, etc. The realization of these tasks was enabled through the press, radio, exhibitions, during the visit by locals of theatres and also through the "Ukrainskye Slovo" newspaper later "Nove Ukrainskye Slovo" (Державний архів Київської області, 2).

It's proved by documents that the most part of work in that direction fell just on the radio. Nearly every day on the radio letters of citizens were read and given answers on them. There were transmitted messages about meetings of citizens through loudspeakers if it needed to be carried out urgently, etc.

As a part of offensive troops of Germany near Kyiv and Dnipropetrovsk in the fall of 1941 two central radio stations for East countries were created. They served as so-called repeaters of transfer and dissemination of information from Berlin across all territory of "Reykhskomissariat of Ukraine2 and zones of military authorities. Under their direct control began the activity of mobile broadcasting stations (Федеральний архів Німеччини, 56).

Since December 1941 from Kyiv "The central Radio Station of Ukraine" began to work. Further amount of fascist radio stations seened to be in the territory of "Reykhskomissariat of Ukraine". Their number was 16. During 1941-1942 the fascist occupational administration actively created a network of broadcasting in all territory of "Reykhskomissariat". They were controlled by occupational administration and troops of "Wehrmacht". Since January 1943 when the position of the Hitler's army on fronts against the Soviet Army reeled, the occupational administration began to create the cable agencies and stations of broadcasting together with local government showing the loyalty to locals. In this regard "Society of Information for Ukraine" was founded. It was located in Rivne but conducted broadcastings spread almost to all territory of "Reykhskomissariat" (Коваль, 1988, 157).

In many regional cities there were created Ukrainian Administrative broadcastings. So in Kyiv, such administration was created in December 1941. It had to broadcast in Ukrainian anti-Comintern and anti-Bolshevist propaganda. Its tasks also included propaganda of the ideas of New Europe and the leading role of the German people in the creation of a new system and partnership of the Ukrainian people in this work. The obligation to organize educational, literary, music and other programs contributed the cultural development of the population and its rest on the radio were assigned to an administration. Besides, Ukrainian administrative broadcastings had to submit the message of the Supreme Command of Germany and allied armies. These were the main announcements of the government of Kyiv relaying of a programme of the German stations, reviews of the press, articles of national 
and educational contents, broadcast of God's service, broadcast of performances, concerts of classical and modern western and Ukrainian music, Ukrainian national songs, literacy programs, etc. (Державний архів Київської області, 3).

It should be noted that the religious policy of Nazis in the occupied territory during an initial stage of the war was rather loyal. It was caused by the need of positive influence on the population. Giving certain opportunities for the activity of Orthodox church the Hitler's leadership sought for reduction of oppositional moods among the Ukrainian population. Such "religious freedom" promoted the revival of the Orthodox church life. So, the Orthodox church in "Reykhskomissariat of Ukraine" and in a zone of military authorities was used as a lever on the population for the purpose of carrying out a more effective occupational policy of the Reich (Гордієнко, 1998, 107).

In early 1942 an active recruiting campaign of Ukrainian workers began in Germany. In Kharkiv the recruitment of workers began in December 1941. Even with the active propaganda and agitation those who wanted to go to Germany became less and less. In this regard the occupation authorities of the Kharkiv region and the Kharkiv city administration began to increasingly use radio and speakers to appeal to young people and middle-aged people to work in Germany (Скоробагатов, 2004, 113).

From the report of the former professor of history of church at theological faculty of the Konigsberg University Hans Koch who well knew Russian and also Ukrainian languages, character of East Slavs and during World War II was the officer of the German intelligence we know and can do conclusion that the Hitler's government considered radio as the most influential media. But as it was stressed above in the villages and the towns of Ukraine there were catastrophically not enough receivers. If in the cities it was carried out a radio communication, in villages the occupying authorities could install only loudspeakers. Thus, most of the population lived in villages propaganda in the rural zone had a smaller effect in comparison with rural population. By the beginning of September 1942 in the Ukrainian regional cities the leading role of radio was adjusted. There were 2000 loudspeakers for 200000 people. It was not enough. The posters were a less effective remedy than broadcastings. Due to the shortage of loudspeakers of local administration it was offered to apply photomontages which somehow would have shown new war events, pictures of working Ukrainians in the "Reich" and a trip of the Ukrainian workers and peasants across Germany (Центральний державний архів громадських об'єднань України, 9).

In Kirovohrad the leading radio had with 35000 loudspeakers. It transferred messages and music from Kyiv and from "Gustav" radio station 
of Dnipropetrovsk. The city commissioner who was engaged in work of radio was responsible for the work of radio and content of broadcast (Центральний державний архів громадських об’єднань України, 11-12).

In September 1943 when fascist troops conducted defensive actions under the pressure of the Red Army radio among rural workers became more active. So, in the Dnipropetrovsk region, the occupying authority explained to the Ukrainian peasants that the German army would return soon and therefore the Ukrainian did not need to be supported Bolsheviks who would bring on the Ukrainian land a grief and tears (Поліщук, 1998, 19).

Oral broadcasting was widely used together with printing propaganda. The texts of programs of oral broadcasting were, as a rule, simple according to contents and short. They repeatedly transmitted them through loudspeakers as announcers used captured Red Army men and also often girls from the local population (according to the German experts in the field of the psychological war, female voices better perceived by soldiers).

In radio propaganda promotion, except trophy Soviet long-wave stations, mobile radio stations of "Wehrmacht" were used. They carried out broadcasting in German for the troops and on the population of occupied territories. Especially Ukraine population happened historically to be experienced powerful radio brainwash.

Often various forms of propaganda were used at the same time and in a complex. Most often it was a combination of printing production and oral broadcasting through loud-speaking installations.

Generally broadcastings played an extremely important role in Hitler's informational propaganda. to sum it up we can conclude that despite a large number of loudspeakers and a wide network of fascist radio the majority of villages remained out of the German information space. In the rural zone and small towns, there was practically no press. There was one loudspeaker on all settlement. But the message of guerrilla connections got into the most remote corners of occupied territories. It very much disturbed occupational administration and forced it to apply certain measures.

\section{REFERENCES}

1. Шпенглер О. 1998. Закат Европы. Очерки морфологии мировой истории. В 2 т. Т. 2. Всемирно-исторические перспективы. Перевод с немецкого. Москва : Мысль.

2. Волковский Н.Л. 2003. История информационных войн. В 2 ч. Ч. 2. Санкт-Петербург: Издательство «Полигон».

3. Вороненкова Г.Ф. 1999. Путь длиною в пять столетий: от рукописного листка до информационного общества. Национальное 
своеобразие средств масовой информации Германии. Москва : Изд-во «Языки русской культуры».

4. Периодическа печать. 1992. Электронная еврейская энциклопедия Доступ 20 июля 2017. URL: http://www.eleven.co.il/article/13190\#02.

5. Энциклопедия третьего рейха. 1996. Москва : Локид-Миф.

6. История Второй Мировой войны. 1974. В 12 т. Начало войны. Подготовка агрессии против СССР. 1939-1945. Москва : Воениздат. Т. 3.

7. Коваль М. В. 1988. Общественно-политическая жизнь трудящихся Украины в годы Великой Отечественной войны: Сборник научных трудов Киев: Наукова думка.

8. Косик В. 1998. Україна Другій світовій війні у документах: Збірник німецьких архівних матеріалів. Львів: Львівський національний університет ім. Івана Франка. Т. 2.

9. Ивлев И.А., Юденков А.Ф. 1988. Оружие контрпропаганды, Советская пропаганда среди населения оккупированной территории СССР. Сборник материалов. Москва : Мысль.

10. Черняков Б. 2006. Окупаційна преса Рейхскомісаріату Україна: розбудова і функціонування (1941-1943 рр.). Наукові записки. Збірник. Київ: Видавництво Інституту політичних i етнонаціональних досліджень ім. І.Ф. Кураса НАН України.

11. Державний Російський воєнний архів. Фонд 1358. Оп. 1. Спр. 1.

12. Німецько-фашистський окупаційний режим на Україні. 1963. Збірник документів i матеріалів. Київ: Державне видавництво політичної літератури УРСР.

13. Центральний державний архів вищих органів влади та управління України. Ф. 3206. Оп. 2. Спр. 74.

14. Гитлеровская пропаганда юдофобии в прокламациях и карикатурах 2005. Автор-составитель Авербух С.Л. Київ : Украинский Центр изучения Холокоста.

15. Волинь. Часопис для Волині. 1941. 12 вересня.

16. Волинь. Часопис для Волині. 1943. 25 листопада.

17. Волинь. Часопис для Волині. 1942. 12 лютого.

18. Жадов А. С. 1978. Четыре года войны. Москва: Воениздат. Доступ 7 октября 2018. URL: http://militera.lib.ru/memo/russian/zhadov_as/ index.html

19. Вінницькі вісті. 1941. № 16.

20. Вінницькі вісті. 1941. № 14.

21. Вінницькі вісті. 1942. № 63.

22. Сумський віник. 1941. № 6.

23. Вінницькі вісті. 1943. № 56. 
24. Вінницькі вісті. 1942. № 63.

25. Косик В. 1998. Україна Другій світовій війні у документах: Збірник німецьких архівних матеріалів. Львів: Львівський національний університет ім. Івана Франка. Т. 2.

26. Нове Запоріжжя. 1942. № 88.

27. Нове Запоріжжя. 1943. № 4.

28. Вінницькі вісті. 1941. № 13.

29. Вінницькі вісті. 1941. № 14.

30. Сумський вісник. 1941. № 1.

31. Сумський віник. 1941. № 6.

32. Центральний державний архів громадських об'єднань України. Фонд 1. Оп. 22. Спр. 390.

33. Волинь. Часопис для Волині. 1941. 1 вересня.

34. Нестеренко В.А. 2004. Аграрні перетворення окупаційних властей у військовій зоні України, 1941-1943 рр. Сторінки воєнної історії України: Збірник наукових статей. Київ : Інститут історії України НАН України. Вип. 8 Част. 1.

35. Державний архів Сумської області. Фонд 1858. Оп. 1. Спр. 2.

36. Центральний державний архів громадських об’єднань України. Фонд 1. Оп. 22. Спр. 390.

37. Волинь. Часопис для Волині. 1942. 1 січня.

38. Вінницькі вісті. 1941. № 7.

39. Вінницькі вісті. 1941. № 14.

40. Донецкий вестник. 1942. 29 декабря.

41. Донецкий вестник. 1942. 9 августа.

42. Донецкий вестник. 1941. 15 ноября.

43. Бахмутский вестник. 1942. 8 июня.

44. Нове Запоріжжя. 1942. № 105.

45. Волинь. Часопис для Волині. 1941. 1 вересня.

46. Державний архів Сумської області. Фонд 1955. Оп. 1, Спр. 15.

47. Державний архів Житомирської області. Фонд 1153. Оп. 1. Спр. 9.

48. Волинь. Часопис для Волині. 1941. 30 листопада.

49. Салата О.О. 2005. Значення економіки України у створенні оборонного потенціалу СРСР у період оборонних боїв (22 червня грудень 1941 р.). Київ : Видавництво Київського національного університету імені Тараса Шевченка.

50. Нове Запоріжжя. 1942. № 109.

51. Вінницькі вісті. 1941. № 21.

52. Державний Архів Харківської області. Фонд 3188. Оп. 1. Спр. 2.

53. Волинь. Часопис для Волині. 1942. 22 січня. 
54. Волинь. Часопис для Волині. 1942. 29 січня.

55. Волинь. Часопис для Волині. 1942. 1 січня.

56. Волинь. Часопис для Волині. 1941. 26 жовтня.

57. Державний архів Рівненської області. Фонд Р-22. Оп. 1. Спр. 29.

58. Вінницькі вісті. 1941. № 19.

59. Гальчак С.Д. 2004. «Східні робітники» 3 Поділля у Третьому рейху: Документи, нацистська каторга, опір поневолювачам. Український національний фонд «Взаєморозуміння і примирення» та ін. Вінниця: Книга-Вега.

60. Центральний державний архів вищих органів влади та управління України. Фонд 3206. Оп. 2. спр. 71.

61. Центральний державний архів вищих органів влади та управління України. Фонд 3206. Оп. 2. Спр. 68.

62. Державний Російський воєнний архів. Фонд 1363. Оп. 5, Спр. 56.

63. Допрос подсудимого Шпеера. 1946. Из стенограммы заседания Международного Военного Трибунала от 21 июня 1946 г. Доступ 10 марта 2015. URL: http://historic.ru/books/item/f00/s00/z0000021/st 018.shtml

64. Державний архів Вінницької області. Фонд Р-6022. Оп. 1. Спр. 13.

65. Державний архів Вінницької області. Фонд Р-6022. Оп. 2. Спр. 17.

66. Лисенко О.С. 1998. Церковне життя в Україні. 1943-1946 pp. Київ : Інститут історії НАН України НАН України.

67. Стернин Г.Ю. 1970. Карикатура. Большая советская энциклопедия. Т. 11. Москва : Издательство «Советская Энциклопедия».

68. Вінницькі вісті. 1942. № 43.

69. Вінницькі вісті. 1942. № 81.

70. Волинь. Часопис для Волині. 1943. 7 жовтня.

71. Центральний державний архів громадських об'єднань України. Фонд 1. Оп. 22. Спр. 82.

72. Центральний державний архів громадських об'єднань України. Фонд 1. Оп. 22. Спр. 81.

73. Петров В.Л., Шолохов С.Н., Снегуров А.В. 2001. Применение нейрофизиологической концепции интеллектуальной деятельности человека для моделирования сложных систем управления - объектов информационного противоборства. Збірник наукових праць. Харьков: Харьковское военное училие. Вип. 4(34).

74. Шариков А. 2008. Политическое радио через призму истории. Режим доступу до журналу: Журнал «Broadcasting. Телевидение и радиовещание» № 3, Доступ 14 июля 2018: URL: http://broadcasting.ru/ articles2/humanit/history-radio. 
75. Jowett G., O’Donell V. 1992. Propaganda and Persuasion. Newbury Park etc. Stuttgart.

76. Международный интернет-журнал “Русский глобус". 2004. № 12, декабрь 2004. Доступ 4 июля 2019: www.russian-globe.com/N34/ Lulechnik.NemstuVAmerike1.

77. Радиожурналистика. 2000. Учебник. Под редакцией A.A. Шереля. Москва: Издательство московского университета. URL: http://evartist.narod.ru/ text5/44.htm.

78. Радиовещание в Третьем Рейхе. 2009. Доступ 30 июня 2019: http://mirslovarei.com/content_his/RADIOVESHHANIE-V-TRETEMREJXE-52288.html

79. Ширер У. 1991. Взлет и падение третьего рейха. Перевож с английского. Под редакциуй О.А. Ржешевского. Москва : Воениздат, Т. 1.

80. Киевский телеграф $1-7$ июля 2005. № 26 (268). Доступ 7 жовтня 2019: URL: http://209.85.129.132/search?q=cache:e4EK1vWJBb0J: www.telegrafua.com/268/history

81. Державний Російський воєнний архів. Фонд 1358. Оп. 1. Спр. 6.

82. Державний Російський воєнний архів. Фонд 1363. Оп. 1. Спр. 67.

83. Державний Російський воєнний архів. Фонд 1363. Оп. 1. Спр. 78.

84. Жолквер-Краснопольской В. Радиополитика и радиопропаганда в Третьем Рейхе. Доступ 7 жовтня 2019. URL:http://209.85.129.132/search? q=cache:0oaoxU1ynaAJ:www.radioscanner.ru/info/article

85. Державний Російський воєнний архів. Фонд 1363. Оп. 1. Спр. 88.

86. Окороков А. 2007. Особый фронт. Немецкая пропаганда на Восточном фронте в годы Второй мировой войны. Москва: Русский путь.

87. Федеральний архів Німеччини (Bundesarchiv). Фонд R 55/606.

88. Юденков А.Ф. 1971. Политическая работа среди населения оккупированных советских территория 1941-1944. Москва : Политиздат.

89. Державний Російський воєнний архів. Фонд 1358. Оп. 1. Спр. 1.

90. Державний Російський воєнний архів. Оп. 1. Спр. 6.

91. Державний Російський воєнний архів. Фонд 1363. Оп. 1. Спр. 88.

92. Орлов Ю.Я. 1985. Крах немецко-фашистской пропаганды в период войны против СССР. Москва: Издательство Московского университета.

93. Немецко-фашистский оккупационный режим (1941-1944 гг.). 1965. Сборник статей. Под редакцией Е.А. Болтина. Москва : Политиздат.

94. Ведєнєєв Д.В. 2003. Розвідувальна діяльність Української повстанської армії (1943-1945 рр.). Проблеми історії України: Факти, 
судження, пошуки: Міжвідомчий збірник наукових праць. Київ : Інститут історії України НАН України. Вип. 10.

95. Вінницькі вісті. 1941. № 100.

96. Державний архів Київської області. Фонд 2356. Оп. 3. Спр. 1.

97. Федеральний архів Німеччини (Bundesarchiv). Фонд R 55/606.

98. Коваль М. В. 1988. Общественно-политическая жизнь трудящихся Украины в годы Великой Отечественной войны: Сборник научных трудов. Киев: Наукова думка.

99. Державний архів Київської області. Фонд 2356. Оп. 3. Спр. 1.

100.Фонд 2356. Оп. 3. Спр. 4.

101.Гордієнко В.В. 1998. Німецько-фашистський окупаційний режим і православні конфесії в Україні. Український історичний журнал. № 3. Київ : Інститут історії України НАН України.

102.Скоробагатов А.В. 2004. Харків у часи німецької окупації (1941-1943). Харків: Прапор.

103.Центральний державний архів громадських об'єднань України. Фонд. 57. Оп. 4. Спр. 196.

104.Поліщук Я. 1998. Рівне. Мандрівка крізь віки: Нариси історії. Рівне: Ранок. 


\section{SECTION 3.2. \\ PROPAGANDA FILMS AND THEATERS DURING THE WAR YEARS: THEIR TOPICS, GOALS, TASKS AND FUNCTIONS}

Cinematography was an integral part and means of forming the information space in the occupied territories.

Cinematography as a means of propaganda can make an extremely high emotional impact. It actively generates an illusory picture of the world in an idealized form in the imagination of viewers. In accordance with the author's conception, the film may arbitrarily create in the viewer a sense of "justice" and moral rightness of a particular character, regardless of its true role in history. At the same time, a propaganda impact on a person is hidden on an emotional level, beyond his/her conscious control.

Any rational counterarguments do not work in this case. For example, at a rational level, we all well understand who Adolf Hitler was and what he did. However, using the game of talented actors and special dramatic techniques, the film director may well create and demonstrate everything so that the sympathy of the audience will clearly be on the side of the Führer. His terrible crimes may not seem like a crime, but rather a noble cause - because the victims themselves will look like villains who deserve to be destroyed.

Cinematic art is an important and powerful tool, which was not ignored by any of the belligerents - neither Germany nor the USSR. In the 20-30's of the twentieth century German cinematography has gained world recognition due to the identity and talent of German actors and directors. But since the first years of the National Socialist Party's coming to power in Germany, cinema has become a part of the "Gleichschaltung" program - the conquest of all German spheres of life by Nazi ideology. Even then, J. Goebbels, who was appointed as a Minister of Public Education and Propaganda, was entrusted with the control of cinematography at all stages - from production and "racially alien elements" to rental and creative process openly declared: "I want to use cinema as an instrument of propaganda" (Энциклопедия третьего рейха, 1996, 256).

Imperial Chamber of Cinematography was created for the development and control of cinema. It supervised the film industry of the Third Reich, and membership in it was a must for creative film production workers. It existed 
organizationally as a sub-chamber of the Imperial Chamber of Culture. In 1937 J. Goebbels established control over the last independent film company in Germany - the UFA film studio. From that moment, all funding for film production was concentrated in the hands of the Nazi authorities.

J. Goebbels was especially proud for the opportunities of the German cinema. He wanted every newspaper and a book read by the people, each film and radio broadcast were permeated with the spirit of a great idea of victory, then, in his opinion, people would no longer be able to reflect on something else. Goebbels openly admitted that historical truth should not be objectively truthful. The only goal of the country's leadership should be success. He proclaimed that Machiavelli proclaimed 500 years ago, namely: the sole purpose of propaganda was the artistic management of affairs (Родс, 2008, 18).

The film for Goebbels has become a special tool of propaganda and a means to create the necessary information space. Both in Germany and on the territory occupied by the German-fascist army of countries, this new kind of art could reach a larger audience than literature and theater. In addition, cinema with its usual themes - intense interest, adventures, love, crimes, and murders - should be addressed to the poorest human intelligence. Thanks to the government's stimulus the visiting of cinemas in Germany during ten years from 1933 to 1942 grew fourfold. One of the most important tasks of cinematography was the imposition of a certain way of thinking among young people (Родс, 2008, 19-21).

Despite the fact that films were created by well-known filmmakers and producers, the creative level of new films was not always high. This is due to the fact that all films were subject to mandatory censorship for the Third Reich ideas. Thus, almost all of the films had propagandistic content. Between 1933 and 1939, such well-known films as "The Fierce SS Fighter", which glorified the exploits of the attack aircraft, films by Leni Riefenstahl "Triumph of the Will" and "Olympia", which featured Olympic Games in Germany in 1936, series of anti-Semitic films "Rothschild in Waterloo", "Jewish Zuss" and others (Родс, 2008, 257).

The German authorities conducted massive reviews of such films. But, apart from the organized columns of assault rifles, which stepped to the cinemas, virtually nobody watched these films - the civilian population simply ignored them.

In the early years of the Second World War, Nazi films praised the triumphant feats of the Wehrmacht soldier, in a caricatured form showing the opponent as weak, sneaky and timid. The German newsreel daily reported on the victories of the war fronts to the population of Germany and the inhabitants of the occupied territories. Since 1943 the content of most films 
has begun to change. Then, due to every battle took place in difficult conditions for the Nazis, they gave false information to raise the fighting spirit of the army and the nation.

Having convinced that film propaganda is an effective means of creating the necessary information space; the Nazi command began to actively work on the creation of films for the population of the occupied territories. These were predominantly films about the difficult life in the Soviet Union in the prewar period (about hunger, collectivization, repression, etc.), about a highly cultured life in Germany, how to work well for eastern workers at German enterprises, and more.

In the structure of the Ministry of the Eastern Occupied Territories, a department of the 18th group was created which was responsible for the activities of cinematography in the occupied territories of the USSR. It provided the occupation administration with film production, which included weekly reviews, propaganda films, educational films, short films and documentaries that demonstrated the life in Germany (Державний Російський воєнний архів, 39).

In many cities of occupied Ukraine, German fascist invaders opened cinema halls. German security and intelligence officials reported on their work to Berlin: "Film propaganda is much more convincing than leaflet and newspapers propaganda, it is affecting the Ukrainian population not only by word but also by moving pictures. Unfortunately, in most cases such films come only in the third grade and do not constitute a very high value in propagandistic terms. First of all, the chronicle, documentary films on the life of the Germans in Germany are of interest in, as well as some valuable German movie films, which, on the one hand, satisfy the desire of the population, and on the other, provide a broad opportunity to knock out the ground from under the feet of propaganda of the enemy" (Энциклопедия третьего рейха, 1996, 258).

The first motion pictures, which served as propaganda, appeared in the occupied territory of Ukraine in the first days of occupation. These movie theaters about the "friend of Russian nation - Adolf Hitler" (Hitler-liberator, 1941 and others) talked about the liberation mission of the German army.

In order to promote propaganda of the film production, a special division was established - the Central Cinematic Association "East" with two branches: the "Ostland Film" with the authoritie in Riga and "Ukraine-film" with the authorities in the Reichskommissariat of Ukraine in Kyiv. This cinematic society specialized mainly in two types of products - a weekly review of events abroad with the translation on the languages of the peoples of the USSR and full-length propaganda films. 
All propaganda cinematographs shot at the Berlin Film Studios were shown in the occupied territories of Ukraine. These film studios also duplicated weekly reviews in the Oriental languages. Great popularity in Germany and in the East used films about the culture of Germany (Федеральний архів Німеччини, 59).

Significant interest in the population of the occupied territories was caused by feature films, both German and Soviet. But the Nazi authorities were not interested in watching Soviet films by the local people that influenced the patriotic feelings of Ukrainians. The demonstration of purely propaganda materials, which according to eyewitnesses, were later triggered by the population of the occupied territories only disgusted. Subsequently, the vast majority of locals tried to avoid watching German films (Окороков, 2007, 38; Салата, 2009, 125-126).

So, already in the first months of the Great Patriotic War the German filmmakers created the "Ninochka", set in the Russian scenario. But the film was only a few weeks left. The German Occupation Administration decided that the film "Ninochka" was too political, and that local people needed something easier, and therefore took it out of revision (Федеральний архів Німеччини, 7).

The first German films were without translation, so most Ukrainian viewers did not understand what was happening on the screen. Subsequently, the German occupation administration began to recruit translators from among the locals, and the vast majority of documentaries were translated into Ukrainian and Russian. Despite the fact that very few people attended cinemas, German propaganda authorities wrote about watching such films in the newspapers that local people were happy to go to their viewing, got aesthetic pleasure from playing actors and music (Нове Запоріжжя, 1942, 4).

During April-September 1942 in order to increase the moral and psychological impact on the local population, the Nazi command almost in all clubs in Podilia, demonstrated the propaganda film "The Road to Germany" (Гальчак, 2004, 59). In order to attract the attention of the population, in a number of places were equipped photo-treadmills, opened the traveling exhibitions that praised the "Nazi paradise", talked about the happy life of workers from the East.

In March-September 1943, the German Armed Forces Staff and the Commander-in-Chief of the Land Forces of the South issued an order for the work of cinemas in the regional centers: Korostyshev, Fastiv, Bila Tserkva, Vasilkiv, Zhytomyr, Ovruch, Nizhyn, Kyiv, Pereiaslav and other cities of the Reichskommissariat of Ukraine (Державний архів Київської області, 136). A separate order was issued on the work of the cinemas in the Kyiv region. 
The Nazi occupation authorities paid special attention to the population of this region, since Kyiv and the region are a politically active region formed prior to the occupation (Державний архів Київської області, 154-169).

From October 1941 the expulsion of Ukrainian citizens to work in Germany was expanded. At first they were trying to recruit voluntarily. For this purpose, propaganda films about good working conditions in Germany and about what modern enterprises were waiting for employees to work began to show.

An example of propaganda material can be a propaganda film intended to demonstrate to the population of the occupied territories of the USSR, about Ukrainian youth, exported to work in Germany. The film tells how well the girls and boys live in Germany. Girls work on farms of German masters, where their children are cared for and work on the plots, and the boys work in modern well-equipped enterprises... (Центральний державний кінофотофоноархів України імені Г.С. Пшеничного).

Next, one of the German newspapers "German Weekly Review" in 1943 has shown how prisoners of war from the Soviet Union lived well, in particular, in Berlin, Soviet prisoners of war, who have just arrived, fit on clothes and shoes at the store before being sent to German enterprises (Центральний державний кінофотофоноархів України імені Г.С. Пшеничного).

About the workers exported from the Donetsk region and the Kharkiv region, tells the film magazine "German Weekly Review" № 615, 1943. The viewer can see a huge shop, with a large number of heavy machines, which are used by Ukrainian specialists: turners, welders. Though their faces are tired and exhausted, the announcer tells us that they are learning new professions that they can then apply in their native country, about how workers from Ukraine work and rest well (Центральний державний кінофотофоноархів України імені Г.С. Пшеничного).

Practically a film "We Go to Germany" shot by the German director G.A. Dalstv and operator V.F. Ludtke was demonstrated in all cities of Ukraine.

The film tells about the journey of Ukrainian girls and boys who voluntarily went to Germany. The journey begins from the village to Kyiv in carriages, then by rail to the large German industrial city. The announcer, commenting on the screen, remarks that those who go to Germany is provided with good food rations, a bottle of vodka, hot food at each station, medical care. In Germany, at the destination, a solemn meeting and a comfortable bus, which takes them to places of work, are waiting for those arriving (Окороков, 2007, 39). 
This film shows the working conditions at German factories, life and leisure. The audience sees clean shops, living rooms of the hostel, and shelves of shops where you can buy any trifle. See also the dining room, hairdressers, shower room, swimming pool, stadium, where the workers from the Eastern countries are happy to play football (Окороков 2007, 40).

The film director tried to convince the population of the occupied territories that the workers from Ukraine in Germany felt really good, that there was peaceful work for the Great Germany and Ukraine. Throughout the film, the idea that working in Germany gives prospects is imposed, that you can become a master and return to the Motherland and, with modern engineering knowledge, become a great specialist.

As we see, cinema is a very effective means of propaganda, it is capable of influencing human emotions and consciousness. The films featured by the occupation authorities for the population were intended to show Germany as a highly cultured state that carries the culture of the occupied territories and freedom from the Bolshevik regime. According to the plan of the German authors and directors, the cinema had to produce great moral and psychological influence on people, to provide support to the local population and to facilitate the Nazi military moving further east, into the country.

The propaganda effect of such films on a person was hidden, on an emotional level, beyond its conscious control, creating the picture of the contemporary present, necessary for the occupation authorities. For example, as already mentioned above, it would seem that the population of the occupied territories is well aware of who Adolf Hitler is, what army he led and why came to the Ukrainian lands, but after watching propaganda films, people sometimes rethought about it. Here is one of many examples of such cinema propaganda: "Hitler's Children", "The Union of German Girls" and others, which show Hitler's infinite love for children. Most of population, watching such films, thought: if Hitler so loves children, he could not carry out those terrible crimes that accused him.

There were people who, in the first months of the war, believed in such propaganda, believed that Ukrainian workers lived well in Germany, and they worked at the enterprises side by side with German workers, but later, when it was possible to communicate with the fugitives, the population of the occupied territories understood, what was actually "Hitler's Paradise". Here are some eyewitness comments that were taken to Germany, but they tried to escape. They testified to the Ostarbeiters' journey: "They are dying in trains. Women give birth on the road and newborns are thrown into the windows ... Those who die fall in the train even without straw, and sometimes the dead fall out of the trains and remain on the railroad canvas" (Двинов, 1950, 41). 
In the "Sumy Visnyk" newspaper of October 22, 1941, we can read information on how the population of the occupied territories visited cinemas, where German films were shown. So, on Sunday, October 20, a film screening was conducted for the population - with chronicle and artistic content. The first review of German films, based on the testimony of the occupation authority, took place in the full hall, and featured films were in great demand (Сумський вісник 1941, 2). It is clear that the population went to watch films due to curiosity or fear, but the point that the films had a great influence on the consciousness of the population of the occupied territories is an indisputable fact.

In another edition of the same newspaper, we can see a message that there a cinema was created for the population in Sumy, where the best German films are shown twice a week: "Personal secretary", "Ride for Germany". According to the author of the article we can see that documentary and chronicle films about the greatest in the world history of war, the war for justice, the war against communism (Сумський віник, 1941, 2) were very popular.

Most newspapers by the Reichskommissariat "Ukraine" and in the zone of military occupation tell how you feel friendly and cozy in the city cinemas and that German films gained great popularity among the local population. It is also noted that the cinema chronicles from the place of hostilities are particularly popular (Сумський вісник, 1941, 4). Such articles were written by those who supported the occupation power, and it is unlikely that this testimony can be fully trusted, but among them there were also people who frankly believed that the German authorities would promote the development of Ukrainian culture.

In an information message from the occupied eastern regions № 32 from December 4, 1942 to January 15, 1943, we see that the first German films shocked Ukrainian viewers in Kyiv. These were mostly comedies about love or movies from the secular life of the Germans. Such films should not be shown to the population of the occupied territories. For the show it is necessary to select films that are propagandistic, and not show the secular life of the wealthy circles of Germany (Центральний державний архів громадських об'єднань України, 7).

In each occupied city, a city administration was established, which in fact was responsible for the mood of the local population and advocacy work, conducted in conjunction with the occupation administration. Thus, in Kharkiv, with the advent of the Nazi troops, a Kharkiv city administration was set up, in which the propaganda department acted. The authority of this department was to provide leadership and control over political propaganda in 
the city and surrounding villages. The workers of the propaganda department were supposed to detect hostile elements on the territories occupied by the German-fascist army, and at the same time resolutely apply appropriate measures; to provide political control over theaters, cinema, radio, concerts, meetings, exhibitions, etc. (Центральний державний архів громадських об'єднань України, 55-56).

The structure of the propaganda department also included a cinema inspection. Its task was to organize and assist in the management and demonstration of motion pictures, control over their subjects, provision of technical support and equipment installation, etc. (Центральний державний архів громадських об'єднань України, 59).

The Kyiv City Council, headed by Doctor of Historical Sciences Oleksandr Ogloblin, also worked under the close supervision of the occupation administration, but could solve certain economic issues on its own. Water pipes, tramways and electricity were restored. Along with this, significant work was carried out in the field of culture and education, the functioning of research institutions, sports, artistic and religious institutions, museums, libraries, and preservation of architectural monuments. The employees of the board decided on the development of the Ukrainian theater, the opening of the "Music Hall", the conservatory, the formation of the Writers' Union (Українське слово, 1941, 4).

With the assistance of the City Council in Kyiv, the Ukrainian Red Cross was created to help orphans and prisoners of war. The supervision of the work of the institutions of the health care system was left by the Nazi commandant's office also in the area of authority of the city administration (Українське слово, 1941, 4).

The occupying power actively used all possible means of influencing the population of the occupied territories. Film propaganda has become one of the most widespread means of influence on the Ukrainian population, since it was perceived much easier than other means of propaganda. But the use of active propaganda, in particular cinematography in the struggle against the population of the Soviet Union, was unsuccessful only at the beginning of the war. This is due to the positive mood of a certain part of the population of the occupied territories and their favorable attitude to Hitler's authorities during the initial period of the war.

Film propaganda has made a great contribution to the formation of the German information space in the occupied territories. The main goals pursued by the Nazi authorities, using film propaganda, were:

- creation of the necessary public opinion regarding the occupation power and the USSR; 
- discrediting the Soviet regime;

- undermining the morale of the Red Army and the population of the occupied territories;

- psychological adjustment of the population of the occupied territories to the fact that the Nazi army is invincible.

Summing up the above, it should be noted that the conviction of the population of the occupied territories that the German army was invincible was denied already at the end of 1941. Film propaganda, although it was widespread, but could not properly affect the population, since it was shown mainly entertaining and adventure films, which did not have a significant propaganda burden. The documentary films showed extremely rarely and with obvious propaganda exaggerations that gave rise to the population not to trust their content. Nazi propaganda in the occupied territories, despite its largescale character, was generally ineffective. The population of occupied Ukraine in general did not trust the Nazi authorities and the "new order", since after the Stalingrad campaign, the real state of affairs did not meet the propaganda promises and declarations of the Nazis.

Theaters were played equally important tasks in the intensification of information space in the occupied territories of Ukraine which used by the German authorities as radio and cinema to promote and propagate their own power and new order.

Part of Ukrainian artists: writers, painters, actors and other theatrical figures - remained in the occupied territory by the German army. The German administration understood the influence of these people on the consciousness of the local population, but in order to demonstrate their loyalty in the first period of occupation, they encouraged the work of theaters, the publication of works of Ukrainian writers in the newspapers, and printing of Ukrainian artists' works.

The new order set strict requirements for the activities of Ukrainian artists and cultural figures. The German administration encouraged them to create cultural and educational organizations through which they sought to influence the population of the occupied territories. The activities of such organizations, which stood in the position of struggle for rights to Ukrainian independence, were not limited to educational, cultural and social measures. A widespread phenomenon was the revival and the founding of new educational organizations. Thus, already on October 17, 1941, an article on the revival of the "Prosvita" organization and its task was published in the newspaper "Vinnytski Visti" (Вінницькі вісті, 1941, 2).

The departments of the military administration of the feld- and ortsmenedatur and local self-government bodies helped to establish new ones 
and to revive existing theaters. The development and the activities of the theaters were also engaged in the propaganda of the Wehrmacht. They were engaged not only in the cultural service of the Wehrmacht military, but also in the propaganda processing of the occupied territory. All issues related to the organization of the theaters were to be agreed with the Nazi occupation administration (Титаренко, 2005, 101).

Thus, the order of the General Staff of the German Armed Forces and the commander-in-chief of the land forces of the South oblige to involve the Ukrainian population in cultural work to increase their cultural level, we see that the occupation administration paid much attention to cinema, theaters and concert activities. Among them is the activity of the theatrical society "Power through Joy", which offered works of Western European, in particular German authors (Державний архів Житомирської області, 27-29).

From the report for the month of the Main Department of Enlightenment and Propaganda of the Ministry of Education and Publicity for June 1941, we can see that the theatrical society "Power through Joy" was fully assured of the ministry and also engaged in the collection of corpses and theatrical groups that were tested for reliability (Державний архів Київської області, 5).

In the first months of occupation, the German occupation authority encouraged the activities of educational institutions, theaters, museums, and individual scientific institutions. On the other hand, the German occupation administration carried out regular campaigns to check on political confidence all those who agreed to cooperate, and first of all, lecturers and teachers. The actors from the local theaters, who were supposed to bring the inhabitants of the occupied territories the idea that the occupation authorities want to preserve the Ukrainian culture and give it a new life, were also checked for reliability. As a result of such events, theaters and educational institutions became led by people completely loyal to the "new" power (Шайкан, 2005, 313).

Under such conditions, during the first months of occupation, for example, in the territory of the Vinnytsia region, a cultural revival began; social life was partially intensified, new and opened previously founded various professional and amateur creative circles, performances of theatrical performances, movie theaters were shown on the works of Ukrainian and German authors. Much of the editors and journalists involved earlier in the press publishing house also continued to work with the only difference that they printed products under the close supervision of the German administration (Безсмертя. Книга Пам'яті України. 1941-1945, 2000, 518).

The theater was played an important place in the information space and the impact on the population of the occupied territories. So, in Zhytomyr - the city theater under the direction of I. Klepachenko staged performances 
"Zaporozhets after the Danube" (ukr. Zaporozhets za Dunaem), "Natalka Poltavka". The first performance of the Ukrainian theater on the works of S. Vasylchenko "On the first party" (ukr. Na pershi guli) and V. Dmytrenko "Godfather Miroshnyk" (ukr. Kum Miroshnyk) took place in Berdychev, on August 26, 1941. In Lutsk, under the direction of the theatrical figure P. Orla, a theatrical ensemble was organized, which began its theatrical season on August 31, 1941 (Волинь. Часопис для Волині, 1941, 4).

As V.A. Nesterenko notes, archival materials collected in Sumy region, show the development of theatrical art in the military zone. Dramatic theaters in Konotop, Sumy, Okhtyrka, Hlukhiv, Romny, Shostka were acting in Sumy Region, the performances took place in Krolevets, the drama group acted in the village of Chausy, Shostka district, and the puppet theater in Sumy. In Chernigiv region there are theaters in Chernigov, Nizhyn, Ostriv, Pryluky, Novgorod-Siversky. In the Kharkiv region, theaters were in Kharkiv (5 theaters), Krasnograd, Merefi, Bogoduhov. In Voroshilovgrad Region, theaters were in Voroshilovgrad (2 theaters), Lozovo Pavlivtsi, Krasnyi Luch, Popasna; theatrical circles in the villages Uspenka, Chuguev, Almazne. In the Donetsk region they were in Yuzivka (3 theaters), Bakhmuti, Kostyantynivka, Druzhkivtsi, Mariupol, Slavyansk and other cities and regional centers (Нестеренко, 2005, 55).

With the beginning of the German occupation in the cities of the Ukrainian SSR - Lviv, Kyiv, Dnipropetrivsk and others - artists who did not have time to evacuate or remained at their own discretion, sought from the German authorities the permission to open theaters. For example, there was an opera theater in Lviv, the "Standart Theater" was opened in Dnipropetrivsk, T. Shevchenko Theater in was opened in Mariupol and others.

Theater and concert activity in some areas of occupied Ukraine was quite active. The theaters acted not only in the cities, but also in the regional centers. For example, T.G. Shevchenko Theater showed 138 performances and 172 concerts, of which for the military -109 concerts during only one year activities in Mariupol (Титаренко, 2004, 167).

In Dnipropetrovs'k, the "Variete Theater", the Ukrainian Drama Theater, the Doll Theater, and the M. Lysenko Chorus Chapel acted. Most of these theaters worked not only for the Wehrmacht armies, but also for the local population and for the "Ostarbeiter" in the Reich. Repertoire of the Choir Chapel consisted of 100 performances in which Ukrainian songs in artistic processing were. Only the march of the Wagner's Tangaiser Operetta was performed in German language (Шайкан, 2005, 326-327).

The activities of local theatrical groups had an important place in the spiritual life of the Reichskommissariat "Ukraine" and the zone of military 
administration. Their repertoire consisted mainly of folk household performances. So in Vinnitsa Ukrainian Theater on September 7, 1941 a big concert took place, where a large number of residents of not only the city but also the environs were gathered. Prominent Ukrainian artists of the ballet Meribel and Peresolov and singers Gutnikova and Kovalska performed there (Вінницькі вісті, 1941, 3).

The performance of Hulak-Artemovsky's opera "Zaporozhets after the Danube" (ukr. Zaporozhets za Dunaem) was demonstrated on two acts in the City Theater on September 14, 1941 (Вінницькі вісті, 1941, 4). On Saturday, October 4, the Ukrainian audience was offered a performance entitled "Wedding in the Goncharivka" (ukr. Svatannia na Goncharivtsi), where the soloists and the whole composition of the ballet were involved (Ведєнєєв, 2003 , 4). Both performances gathered a significant number of residents, most of whom perceived the restored activities of theater groups as a revival of cultural life in Ukraine.

Comedy performances were quite popular among the local population during this period, and the German occupation authorities immediately drew attention and encouraged their first showing. Confirmation of this was the show of "May Night" for the 4 actions in February 1942 in Starytsky City Theater of Comedy. The inhabitants of the city came to such performances, often not only in order to watch the performance, but also to communicate, hear news, and more. (Вінницькі вісті, 1942, 8).

The repertoire of the theaters in Donetsk and the region was diverse. It included works by Western European, Ukrainian, Russian playwrights, composers. As already noted, the local occupation authorities allowed theaters to predominantly entertain performances, avoiding appearances with politicoideological content. The performance and demonstration of the performance depended on the material base of one or another theater. Taking into account the material support and staffing of the theaters, the Yuzovsky Musical Drama Theater and T. Shevchenko Mariupol Music and Drama Theater were the most popular. The repertoire of Mariupol Music and Drama Theater consisted of 18 plays, and Yuzovsky Music and Drama Theater consisted of 17 performances and concert programs. (Гайдабура, 1998, 34-35, 61). This indicates that the Nazi occupation authorities paid attention to this type of propaganda activity.

The plan of conducting performances of the Kyiv Opera House in April 1942 shows that the performances were shown not only to the viewers of Kyiv, but also for inhabitants of the cities and towns of the Kyiv region (Державний архів Київської області, 189).

From the correspondence of the standard commissant with the commandant department of the 393 Main Field Commandant's Office on the 
theater group "Power through Joy" we can see the confirmation of performances during 1942. Among them, the repertoire of the Small Drama Theater: "From Kyiv to Shanghai", "Everything goes by ...". The performance "Hotchpotch" (ukr. Vsiaka Vsiachyna) was demonstrated an Kyiv and the oblast - in the cities of Fastov, Bila Tserkva, Lubny, Khorol, Yagotin, Brovary and others (Державний архів Київської області, 8, 61).

In the German propaganda among the population, the theater was given an extremely important role. It was one of the most influential means of agitation and propaganda that was used by the Nazi authorities in the occupied territories. Activities of theaters were an important part of public life which actively influenced the consciousness of the local population.

On the other hand, it was during the period when the national theater directed its spiritual energy to contacts with its own nation. The theater became such an artistic center that helped Ukrainians to preserve national artistic traditions.

Summing up, it should be noted that the authorities of the Third Reich before the Second World War, and especially the Great Patriotic War, had modern technical means, technologies and methods of forming the information space. The most relevant in this context was the use of broadcasting, cinema and theater activities.

In order to place on own side the creative Ukrainian intelligentsia, the Nazi authorities created the conditions for their activities, which during the initial period of the war gave the possibility to honour national traditions, open educational institutions, dream of an independent Ukraine, and so on. In this regard, the methods of psychological action were used when the occupation administration compared the repressive policy of the Soviet power with its own; a method of distorted truth when the work in Germany was propagated as for the future of Ukraine; misinformation about the real state on the fronts, which led to the loss of hope among intelligentsia for the liberation from the Nazi invaders.

\section{REFERENCES}

1. Энциклопедия третьего рейха. 1996. Москва : Локид-Миф.

2. Родс Э. 2008. Пропаганда. Плакаты, карикатуры и кинофильмы Второй мирововй войны 1939-1945. Москва : Эксмо.

3. Державний Російський воєнний архів. Фонд 1358. Оп. 1. Спр. 1.

4. Энциклопедия третьего рейха. 1996. Москва : Локид-Миф.

5. Федеральний архів Німеччини (Bundesarchiv). Фонд R 55/606.

6. Окороков A. 2007. Особый фронт. Немецкая пропаганда на Восточном фронте в годы Второй мировой войны. Москва : Русский путь. 
7. Салата О.О. 2009. Кінопропаганда як складова інформаційного простору сформованого на окупованій території України в 1941-1944 pp. Збірник наукових праць. Серія «Історія та географія». Харків: Видавництво Національного педагогічного університету імені Г.С. Сковороди.

8. Федеральний архів Німеччини (Bundesarchiv). Фонд R 55/1470.

9. Нове Запоріжжя. 1942. № 112.

10.Гальчак С.Д. 2004. «Східні робітники» з Поділля у Третьому рейху: Документи, нацистська каторга, опір поневолювачам. Український національний фонд “Взаєморозуміння і примирення” та ін. Вінниця: Книга-Вега.

11. Державний архів Київської області. Фонд 2356. Оп. 1. Спр. 6.

12. Центральний державний кінофотофоноархів України імені Г.С. Пшеничного. 1942. Фонд Арх. № 3254. ЦФО, УФА (Німеччина) Кіножурнал.

13. Центральний державний кінофотофоноархів України імені Г.С. Пшеничного. 1943.Арх. № 3274. ЦФО, УФА (Німеччина) Кіножурнал.

14. Центральний державний кінофотофоноархів України імені Г.С. Пшеничного. 1943. Арх. № 3276. ЦФО, УФА (Німеччина) Кіножурнал.

15. Двинов Д. 1950. Власовское движение в свете документов. НьюЙорк.

16. Сумський вісник. 1941. № 2.

17. Сумський віник. 1941. № 6.

18. Сумський вісник. 1941. № 4.

19. Центральний державний архів громадських об’єднань України. Фонд 1. Оп. 22. Спр. 81.

20. Центральний державний архів громадських об'єднань України. Оп. 23. Спр. 531.

21. Українське слово. 1941. 12 жовтня.

22. Українське слово. 1941. 30 жовтня.

23. Вінницькі вісті. 1941. № 21.

24. Титаренко Д.М. 2005. Театральне життя в Донбасі в період нацистської окупації. Науковий журнал: Історичні і політологічні дослідження. № 1. Донецьк: Видавництво Донецького національного університету.

25. Державний архів Житомирської області. Фонд 1153. Оп. 1. Спр. 9.

26. Державний архів Київської області. Фонд 2356. Оп. 1. Спр. 11.

27. Шайкан В.О. 2005. Колабораціонізм на території рейскомісаріату «Україна» і військової зони в роки Другої світової війни. Монографія. Кривий Ріг: Мінерал. 
28. Безсмертя. Книга Пам'яті України. 1941-1945 2000. Київ : Пошуково-видавниче агенство «Книга Пам'яті України».

29. Волинь. Часопис для Волині. 1941. 1 вересня.

30. Нестеренко В.А. 2005. Сценічне мистецтво у військовій зоні України в 1941-1943 рр. Сторінки воєнної історії України. Збірник наукових статей. - Випуск 9, Частина 3. Київ : Інститут історії України НАН України.

31. Титаренко Д.Н. 2004. Образование и культура Донетчины в 1941-1943 гг. Всеукраинская конференция «Межэтнические связи: история, этнография, культура». Донецк: Донецкий национальний университет.

32. Вінницькі вісті. 1941. № 5.

33. Вінницькі вісті. 1941. № 7.

34. Ведєнєєв Д.В. 2003. Розвідувальна діяльність Української повстанської армії (1943-1945 рр.). Проблеми історії України: Факти, судження, пошуки: Міжвідомчий збірник наукових праць. Вип. 10. Київ : Інститут історії України НАН України. 2003.

35. Вінницькі вісті. 1942. № 11.

36. Гайдабура В.М. 1998. Театр, захований в архівах: Сценічне мистецтво в Україні періоду німецько-фашистської окупації (1941-1944). Київ : Мистецтво.

37. Державний архів Київської області. Фонд 2356. Оп. 1. Спр. 6. 


\section{SECTION 4. \\ INFORMATION CONFLICT AND ITS INFLUENCE \\ ON THE MORAL-PSYCHOLOGICAL CONDITION \\ OF THE POPULATION IN THE REICHSKOMMISSARIAT \\ "UKRAINE" AND IN THE ZONE \\ OF MILITARY ADMINISTRATION}

Needs of working in the conditions of the new information mode forced both Germany and the Soviet Union to create a special system of informational and analytical activity. Considering that both states had totalitarian mode this process considerably became simpler and accelerated. The formation of the information space became more active in Germany. As far as the Soviet Union the process of foundation of information space I was began in the 17-20th years of the 20th century and was caused by Bolshevist ideology.

In occupied territories tasks of the formation of specialized system institutions and divisions, various military, propaganda organizations and analytical services started developing from the first period of the occupation. Informational and analytical services appeared to be in all spheres and began activities in Germany and much earlier in the Soviet Union. Their main aim was to concentrate and process powerful information flows for the purpose of the political and economic problems connected with influence on the population of occupied territories.

There were certain differences between the German and Soviet information and analytical services and conditions in which they were forced to work scurried about. The Hitler's leadership had an opportunity to create in occupied territories libraries and to deliver necessary books and newspapers, to distribute necessary information also directly through broadcastings and cinema. The Soviet leadership worked only through "partisan movement" and "Soviet underground" from among local population by way of the distribution of leaflets and brochures. The Soviet leadership hoped that the "Nonaggression Pact" signed 1939 would constrain Hitler's army from aggression. A evidence of that there was a document prepared and addressed to Stalin by G. Zhukov with the assistance of S. Tymoshenko and A. Vasilevsky. There was one copy. It is told: "I report on your discretion of a reason according to the plan of the strategic expansion of Armed Forces of the 
Soviet Union on a war case with Germany and its allies". But, according to G. Zhukov, Stalin was very careful and therefore regarded this document for an attempt to provoke Germans (Король, 2002, 27-28).

The fascist leadership of Germany understood that completely it was impossible to hide large-scale military preparations from the attention of the Soviet and the other countries researches, therefore. It was examined carefully and prepared the plan of actions on their covers. Disinformation was carried out by the government's administration: "Ministry of National Education and Propaganda", "Ministry of East Occupied Territories" and "Ministry of Foreign Affairs". Hitler, Goering, Goebbels, Ribbentrop directly participated in the development of these actions.

The German propaganda made the first great progress in 1940 in the period of the occupation of France. Several months prior to invasion into France Germans began to use actively so-called "black" transmitters giving them for the French radio stations. Through these stations there were spread critic information about the French government to form the uncertainty and panic moods among the population and the French army. As a result of such active promotion before the German troops, the moral and combat spirit of the French army was undermined and they could not show serious resistance to the opponent (Daugherty, Janowitz, 2001, 671).

After the conclusion of the "Soviet-German Non-Aggression Pact" on August 23, 1939 in the structure of the German propaganda concerning the USSR, there was a cardinal reorganization. Misinformation of soviet leadership was the main objective of this reorganization. According to the specified purpose Goebbels gave the instruction to abstain from open attacks to the Soviet Union. "The opponent needs to be held in information disinformation about plans of Germany" (Панарин 2006, 152) The "Ministry of National Education and Propaganda" established cruel censorship on all materials where there was any information about the USSR and demanded from mass media to show restraint in publications about Russian achievements. In the confidential instruction of Goebbels of January 30, 1940 it was spoken and about expediency to place in periodicals any "positive materials about Russia... because thanks to policy of last years readers are ready absolutely in a different way and would be absolutely confused by sudden change of the direction of contents of publications in the press" (Панарин, 2006, 152). This statement, one of the biggest mistakes of the USSR and a victory of the German propaganda and diplomacy.

Such information policy brought invaluable benefit to Hitler's leadership. The Soviet Union responded to it by own means of anti-fascist propaganda. Attempts of separate newspapers to give an objective assessment to events 
which took place in Germany were exposed to sharp criticism. A last plea in misinformation of the country was the statement of agency "TASS" of June 14, 1941 in which it was said about "obvious senselessness" massed in foreign the seals of rumors about "proximity of war between the USSR and Germany". It was claimed that "rumors about attempt of Germany to begin attack on the USSR are deprived of any bases". But, despite unwillingness to go for confrontation with Germany in the spring of 1941 in Moscow there was decided to apply some "veiled" anti-German actions. In March in "Award meeting" Stalin gave awards authors of the feature film "Alexander Nevsky" (1938). It was the first Soviet movie which carried anti-German orientation. In April 1941 when there was a tension in the Balkans and there was an article about S.N. Eisenstein's creativity in the "Pravda newspaper" (Невежин, 2007, 265).

In March 1941 agency "TASS" began a direct preparation for informational wars against Goebbels's department. The corresponding materials were collected (excerpts from the book "Main Kampf" by Hitler, an article about Nazi "New order" in Poland and Yugoslavia, etc.). As a part of "TASS" there was a new edition of promotion led by Y. S. Hanson. At first, it worked secretly, officially developed the activity only after June 22, 1941.

For fascist Germany became obvious that the Soviet leadership had understood a situation which developed in the East of Europe and therefore stirred up the information and propaganda activity even more. 1940 became the year of extreme activity in propaganda activity of Germany on the Soviet Union. From the end of the year the German departments, carried out propaganda activity against the USSR, began active work on collection of information for the benefit of holding promotional campaigns: materials of the Soviet military newspapers of border military districts and other periodic literature, even large-circulation editions of the plants and departmental magazines were processed illegally receiving.

Those who well knew political, social and economic and cultural features of the people of the USSR, Russian and Ukrainian, in particular, were involved. They prepared analytical materials for propaganda, defined especially weaknesses of the Soviet military personnel, opened obvious problems of the Soviet society, developed recommendations on information and psychological impacts on the staff of the Red Army and the population taking into account national and psychological features, traditions and culture. Army intelligence known to all "Abwehr" banished on the territory of the Soviet Union with intelligence agents and saboteurs (except for the main objective, they had to spread the rumors compromising materials about the country leaders and the command structure of the Soviet Army) specially 
trained agents propagandists - the former emigrants, were fluent Russian, Ukrainian in languages and languages of other people of the USSR and also emissaries propagandists of various national organizations. So, one of "Abwehr" schools directed the first agents propagandists in February 1941, the second - in May 1941 Having received a task prior to military operations "to pave the way" for psychological actions against the fighting structure of the Red Army and the population, they began to act in border military districts. Agents for the performance of the tasks hired the persons offended or dissatisfied with the Soviet power, distributed through them leaflets, rumors, brochures with incriminating evidence of the Soviet government, promoted kindling of national discord and other (Панарин, 2006, 153).

At the end of 1940 the "Department of Propaganda prepared the Directive in the operation "Barbarossa". It also became the main document on the organization and conducting a psychological war against the USSR. In the Directive there were defined the purposes of propaganda, its forms and methods. On June 6, 1941, it was sent to troops.

The USSR also understood the international situation and therefore much attention was paid to the strengthening of ideological and political work among the staff of the Red Army and the population. In particular, on May 13, 1941, at a meeting of film committee of the USSR V.V. Vishnevsky proposed certain measures which according to him should be immediately carried out for comprehensive preparation of cinema for a war. Vishnevsky stopped on an image of the enemy in a future war. He emphasized: "In skilled, skilful hands of writers and directors of film editors, materials will turn into propaganda military movies" (Невежин, 2007, 286).

All types of promotion applied by the USSR actively affected the consciousness of the population. So, conversion propaganda influenced valuable reference points of people with the purpose to change their setups, attitude, thoughts and views, concerning country policy. During 1941-1945 the Soviet military and political leadership tried to convince the population of Germany and fighters of the German army that war from the German army was unfair and aggressive. It was announced that the Soviet Union did not show any aggression to the population of Germany. But, unfortunately, the propaganda of Hitler's leadership was so powerful that a considerable part of the staff of the German army until the end of war remained under the influence of fascist ideology.

Allies of the USSR used also propaganda of intergroup contradictions on the basis of religious, social, professional character for disunity of the opponent. Propaganda's content was being formed in the state circles. It could be the next example. The English propagandists dropped leaflets from the 
plane over Germany and that period a gauylyayter Erich Koch filed to the German people a petition for danger which threatened Hitler by the side of the opponents in Germany too. With such cards English propaganda tried to convince the population of Germany that not everything was so good in the leading circles of the "Third Reich" because the Hitler's leadership stated (Панарин, 2006, 159-160).

Captivity propaganda was the most widespread. It was used by both the German leaders, and the Soviet power. There was a straight line psychological impact on the consciousness of people directed to the formation of positive feelings in relation to surrender as reasonable and safe an exit from the current situation. The specified type of propaganda acted on the territories of Ukraine occupied by the fascist army. The set of leaflets with the corresponding content was distributed. As a rule, such cards were divided into two parts. In one it was told about a bad life in Ukraine under the power of "Bolsheviks" or what sense to shed the blood for the sake of Bolsheviks if the German army won anyway. In another part the admission according to which it was promised all fighters, officers of the Red Army and political commissars who would come over to the side of the German army of war and peaceful life to their relatives (Гитлеровская пропаганда юдофобии в прокламациях и карикатурах, 2005, 106-107). Similar addresses were also to commanders of the Red Army. The Hitler's military authorities convinced that their situation was hopeless and the fight was useless: They were promised: "You pass to Germans - there you are waited by good attitude and food and also fast homecoming" (Окороков, 2007, 30).

Trying to resist the information attack from the German occupational administration, the Soviet propagandists distributed the leaflets not less actively. Their contents were a bit different. So, in leaflets of the Central Committee of $\mathrm{RC}(\mathrm{b})$ for the Ukrainian youth there was said that all remembered how the Soviet people always dealt shortly with traitors. There was given an example, taken from famous literary Ukrainian heroes as Andrey's treason - the son of "Taras Bulba" - and punishment of the father over it (Центральний державний архів вищих органів влади та управління України, 200).

In the following card of the Head political department of the Red Army turned to the population of temporarily occupied territories. It was said: "Who will go to Germans - that will die". It is noted that the German army promptly receded under attacks of the Red Army, the Soviet power would not punish those who remained in the villages and the cities occupied by Germans. The head political department urged the population not to trust the German and the Soviet power and the Red Army had only one purpose: to clean the Ukrainian 
land from Hitler's army, as soon as possible to exempt its population from fascist bondage and to return quiet and joyful lives. Those appeals urged not to succumb to fascist provocation: "Make everything that Germans did not pursue you violently. You remember, companions. The business of Germans it is hopelessly lost. The Red Army successfully clears the Soviet land of fascist aggressors... Wait for arrival of your native Red Army and all means help it with the fight against Hitler. Do not allow Germans to take out the bread and to take away the cattle. Destroy bridges and roads on which Germans will run. Set fire to the German ammunition and food warehouses. Help guerrillas to beat fascist robbers" (Советская пропаганда в годы Великой Отечественной войны: “коммуникация убеждения” и мобилизационные механизмы, 2007, 492). Actually such propaganda was a lie and hypocrisy too. It is known that the people who remained in the territory occupied by the Fascist army or escaped from the German captivity were pursued the Soviet punitive machine ruthlessly (Сборник законодательных и нормативных актов о репрессиях и реабилитации жертв политических репрессий, 1993, 94-96). In this occasion there are many opinions, historians differently assess a situation in the conditions of war and operation of orders and resolutions of Stalin. Administration of "People's Commissariat for Internal Affairs" concerning the persons which left in due time the German environment and remained in the occupied territory or were prisoners. So "About members of traitors families" we see Resolutions of the State Committee of Defense No. GOKO-1926ss of June 24, 1942 , actions were applied by the Soviet power to prisoners of war and their families.

Firstly, to establish that full age members of families of the persons (the military personnel and civil) condemned by judicial authorities or the Special meeting at People's Commissariat for Internal Affairs of the USSR to a capital punishment according to Article 58-1 "a" to CC RSFSR and the relevant articles of the Criminal Code of other federal republics: for espionage in favor of Germany and other countries which were at war with us for transition to the enemy, treachery or assistance to the German invaders, service in retaliatory or administrative organizations of the German invaders in the territory occupied by them and for attempt of high treason and treacherous intentions, are subject to arrest and exile to the remote regions of the USSR for a period of five years.

Secondly, to establish that arrest and exile to the remote regions of the USSR for a period of five years are subject also families of the persons who are in absentia condemned to a capital punishment by judicial authorities or the Special meeting at People's Commissariat for Internal Affairs of the 
USSR for voluntary leaving with occupational troops at release of the territory occupied by the opponent.

Application of repressions concerning members of the families listed in Paragraphs 1 and 2 was carried out by societies of People's Commissariat for Internal Affairs on the basis of sentences of judicial authorities or decisions of the Special meeting at People's Commissariat for Internal Affairs of the USSR. As members of the family of the traitor could be considered to be the father, mother, the husband, the wife, children, daughters, brothers and sisters, if they lived together or were in his dependence by the time of crime execution or by the time of mobilization in army from the beginning of war (Сборник законодательных и нормативных актов о репрессиях и реабилитации жертв политических репрессий, 1993, 93-94).

Such attitude towards fighters and to their families of the Red Army got to captivity was confirmed by the shorthand report of interrogation sent to the "Chief of the Central Headquarters of the Soviet Partisan Movement at the Rate of General headquarters T. Ponomarenko. In the shorthand report of interrogation of the aide-de-camp for special instructions at the chief of staff of the movement A.D. Rusanov, it was noted that the former prisoners of war who came over to the side of guerrillas often were disarmed, sent to the back and destroyed. Sometimes, if there was a need, they would be left in guerrilla groups. But after the war they would be able to be checked waited by department of "People's Commissariat for Internal Affairs". Here A. Rusanov gave evidence that families of the Red Army men who were taken prisoner were pursued only if it was known that he was taken prisoner there and if it was considered the missing person, then the family was even supported (Безыменский, 1981, 418). The attitude of management towards prisoners of war was confirmed by order No. 270 of August 16, 1941. It was already mentioned above where it was said: "Commanders and political workers, which the during fight break signs of distinction from themselves and escape to the back or given in captivity to the enemy, to consider malicious deserters whose families are subject to arrest as families of deserters which broke the oath and betrayed the Motherland. All higher commanders and commissioners must shoot deserters on the place from a division" (Король, 2002, 49).

For the purpose of maintenance of patriotic feelings among guerrillas by the Political administration of the Red Army there was given the order to hide carefully true situation in the Soviet Union. Nobody had to know about hunger in the rear of the USSR and the compulsory mobilization of women and teenagers, people's losses and terror. For these reasons "Guerrillas movement" seemed to appear in the Soviet territory as a result of the arrival of the Red Army away. All possible measures were done to isolate Partisan's 
movement from other mass of Red Army with the aim not to get truth information from guerrillas who stayed in the German rear long time and had read the Nazi opponent's literature, learned about the true situation in the USSR and Stalin's criticism and the Bolshevism. The Soviet leadership recognized the danger of the situation in the Soviet Union and tried to avoid discontent among partisans and the population of the territories occupied by the German army. "Only an insignificant part of guerrillas - Soviet party workers and the staff of 'People's Commissariat for Internal Affair's, - which were specially sent to German rear for the purpose of underground work, sent to other occupied areas for propaganda activities" (Білас, 1994, 420).

The best specialists were involved. Among the, there were A.S. Scherbakov, L.Z. Mekhlis, M.A. Suslov, G.F. Alexandrov. They fixed mechanisms of fast a collection of the necessary information and its processing but often figures and materials which were collected were not true. So, for example, "the Message of the Soviet Information Bureau" prepared by A.S. Scherbakov gave figures of fighting losses. That digital material of messages was not true and consisted in the propaganda purposes. In the last release of the book "Great Patriotic War of 1941-1945". it was noted that losses of Germans in November 1941 in-ground forces were only 750 thousand people (Никулина, Сорока, 1999, 56-60). The following data presented in M.I. Meltyukhov's researches: was that Germans before the war with the USSR had only 3899 tanks and 4841 planes (Мельтюхов М.И. 22 июня 1941 г.: цифры свидетельствуют, 1991, 18). Thus, we see that A.S. Scherbakov's article "destroyed" military equipment of the military adversar approximately twice.

Insufficient knowledge of the enemy - fascist Germany was one of the main reasons for failures of the Soviet promotion among troops of the enemy. A large number of specialists "germanists" of the various profile was for this purpose involved and each hostile connection was accepted fields.

The work began among the population of the Soviet areas occupied by fascist troops. In the directive SNK USSR and Central Committee of the All-Union Communist Party (bolsheviks) of June 29, 1941, to the party and Soviet organizations of front-line areas in Stalin's speech on July 3, 1941, it was indicated the need to explain to workers their situation; to organize uncompromising fight with everyone: alarmists and spreaders of rumors (Бутырин, 2006, 3-4). For the dissemination of this and other information there were given newspapers Pravda, "Communist", "Izvestia", "For the Soviet Ukraine" in the rear the Soviet Army and also other central periodicals. Among the listed periodicals, regularly there was printed a "Vesti Iz Sovetskoy Rodiny" newspaper. It appeared big circulations in the Russian, Ukrainian and 
Belarusian languages for the population of Ukraine and Belarus. It was delivered to the occupied territory by planes and extended underground workers. It should be noted that this newspaper disturbed occupational administration very much which applied a set of means to its destruction.

In one of the special messages of fascist occupational administration, it was noted that the Soviet leadership used psychologically active actions and means of propaganda comparison with an initial stage of war. The special attention was given to newspapers leaflets which were regularly dropped from planes (Всенародное партизанское движение в Белоруссии в годы Великой Отечественной войны (июнь 1941- июль 1944), 1973, 247). The newspaper made the real threat for occupying authorities. The fact that, except satirical materials there were also drawings and documentary photographs which illustrated fight of guerrillas and courage of the Soviet soldiers in fights for Homeland freedom. Regular informing the Soviet people who appeared in occupation about events at the front and in the country, about world situation strengthened in them the confidence of quick freedom, promoted strengthening and activation of the guerrilla fight against the fascist army.

From the Order of the People's Defence Commissar September 5, 1942 "About problems of the guerrilla movement" and from the report of the Ukrainian Headquarters of the partisan's movement we can see that guerrilla groups of Fedorov, Saburov, Kovpak, Melnik and other "partisan" heads gave out and distributed among the population of the occupied areas of Ukraine newspapers and leaflets. Only Saburov's group issued more than 102 names of newspapers, leaflets and bulletins with a general circulation of 156183 copies. For strengthening of printing promotion directly 56 portable printing houses, more than 350 libraries and mobile movie theatres were brought. (Центральний державний архів вищих органів влади та управління України, 23).

From November 1942 to April 1, 1943, it was published and widespread in temporarily occupied territory 103 newspapers in Ukrainian with a general circulation of 8100000 . Besides, 1980000 are newspapers ("Communist", "Soviet Ukraine", "For Soviet Ukraine"). Planes with newspapers and leaflets went along such routes: Kharkiv-Poltava-Sumy, Nezhin-Kiev-VinnytsiaPriluki-Vorozhba, Kyiv-Zhytomyr-Chernihiv, Kharkiv-DnepropetrovskZaporozhye-Stalino-Lugansk, Kupyansk-Kharkiv-Poltava, etc. (Центральний державний архів вищих органів влади та управління України, 24).

Very effective results were yielded by mass and political work among the population during raids of guerrilla on the rear of the enemy. The Communist Party organized meetings, extended political literature. For example, from the shorthand report of a propaganda department meeting, from the report of 
guerrilla groups, we see that with the population of occupied territories discussions were led and then there were given answers to a set of questions. The population, according to heads of guerrilla units raised many questions. People had a keen interest in problems of a political situation as in the rear and at the front. It demonstrated that the population of occupied territories did not trust messages from newspapers of the occupying authority (Центральний державний архів громадських об'єднань України, 3)

Work of "underground" was fragmentary as most the organizations were destroyed by occupational troops. With the participation of the "Kiev city underground" secretary Rudchenko in October-November 6 underground district committees were arrested. The former secretary of Kyiv regional committee and a city town committee of "Komsomo" Kucherenko, the instructor of the regional committee of LKSM of Ukraine Pustovoytov, Aristarkhova coherent of an underground city town committee were traitors. 36 figures of the Kyiv administration in an underground were arrested. On the way of treachery there was also a secretary of the "Zaporizhia underground regional committee" Mosiyevich, He told about the structure of an underground and revealed the second secretary of regional committee Osipov, coherent Moshchenko, secretaries of underground district committees and itself continued to work for the enemy under the pseudonym "Konstantin" (Чайковський, 1994, 20).

Guerrillas provided underground political workers with the central and local newspapers, brochures and leaflets. As a result of it, counteraction to fascist propaganda in large settlements became more expressed, especially during 1943-1944 (Центральний державний архів громадських об'єднань України). Evidence of that what work was done by the Soviet leadership and "Guerrilla units in occupied territories were reports and information certificates of the propaganda content, mass agitation activities on areas in February-March, 1942. (Центральний державний архів громадських об’єднань України, 4-7).

"Guerrillas" widely applied various forms of verbal promotion. On numerous memoirs of participants of the "guerrilla, movement" there were mass meetings and even small demonstrations. So, for example, a broad success among the population received the meeting held on February 1942. In villages of the Sumy region - Dubovichi, the Gorozhanla, Gerasimovka, Shilinka - Putivlsky guerrilla group (Центральний державний архів вищих органів влади та управління України, 180).

The Ukrainian youth of temporarily occupied by fascist aggressors territory actively participated in the edition of brochures and leaflets (Центральний державний архів громадських об'єднань України, 15). 
Only from January to September 1942 it was given out and widespread special issues "Communist" with a circulation of 6 thousand, 31 card.Leaflets went to the occupied areas for the purpose of their distribution through Political Departments of Southwest and Southern fronts. Cards in large quantities extended mainly in Stalin, Kharkiv, Poltava, Sumy, Kyiv, Dnipropetrovsk and Zaporizhia, Voroshilovgrad regions. Except for cards, it was planned to distribute also brochures and newspapers (Центральний державний архів вищих органів влади та управління України, 95-96). Because a considerable part of political departments was liquidated, it became impossible.

The "Komsomol organizations" of the occupied areas included a youth which conducted active counter-propaganda in the back of the opponent. Such groups which bore personal responsibility for timely delivery of literature were organized on the occupied territory (Центральний державний архів громадських об'єднань України, 8, 11, 15, 23, 45).

According to the administration of "Wehrmacht" an important role in the dissemination of this or that information was played by an emotional spirit of the population which promotes the formation of the new power. commitment. Therefore the staff propaganda and troops of SS built the actions, considering first of all a moral and psychological condition of the local population. "Employees practically of all divisions with success used knowledge of psychology and policy, skillfully forwarding behavior of people to the necessary course. The success of Nazi propaganda was provided also with the ruse of the most modern materials and means of dissemination. In the Soviet propaganda activity was insufficiently equipment, materials and personnel. Only correspondents of the army newspaper "Krasnaya Zvezda" and the government newspaper "Izvestia" had planes. Correspondents work interfered because of institute department selfishness (Советская пропаганда в годы Великой Отечественной войны: “коммуникация убеждения” и мобилизационные механизмы, 2007, 32).

Nazi propaganda was carried out generally through periodicals, an air, motion picture art, exhibitions and also the distribution of small printed materials (leaflets, brochures, posters) on city streets, the enterprises, in educational institutions and so forth. Its large-scale character is explained by the application of similar methods in Germany which effectively affected public opinion. Defining the main propaganda objectives and the purposes of use of periodicals in temporarily occupied territory", Reykhskomissariat's leadership issued the special directive. In it, it was said: "The Ukrainian and other newspapers issued in "Reykhskomissariat" - an exclusive lever on the population promotion and policy, by order of "Reykhskomissar". They do not 
serve the national and cultural purposes of the population or even religion... Everyone their line has to help military occupational authorities with the implementation of a great mission of the Fuhrer in the creation of new Europe" (Коваль, 1988, 157-158). The German leaders cared for that antiSoviet propaganda captivated all space of the occupied areas and prevented the distribution of anti-Nazi propaganda.

For counteraction, to enemy propaganda, the special broadcasts prepared toward "underground newspapers". About it on September 16, 1942, at a meeting of Council of military-political propaganda of the Head Political Department of RKKA the issue "About Work among the Population of the Occupied Regions of the USSR" was discussed. It was offered to develop measures for improvement of work of broadcasting for the population of temporarily occupied areas (Партийное подполье в Белоруссии, 1941-1944: Страницы воспоминаний, 1984. 132, 236).

In this regard there was set the task to make the program schedule for all "Guerrilla Radio Committee". Their contents had to include the following questions:

- the materials characterizing situation at the front, statement of the message of "Sovinformburo", special messages of "Sovinformburo", losses of fascist troops;

- the materials characterizing the situation in the Soviet rear;

- fighting of "Partisan movement" of Ukraine;

- commenting of information obtained from abroad;

- articles exposing a lie of Hitler's propaganda;

- cards for the edition in "Guerrilla Units" (Ивлев, Юденков, 1988, 71-72).

Time for carrying out these or those transfers for "Reykhskomissariat's" population Ukraine and zones of military authorities was accurately determined.

Soviet counter-propaganda could not solve completely all problems of war conditions. It could not capture all citizens of the occupied by the fascist army territory. The technical base of the Soviet propaganda on temporarily occupied territories was much weaker than German due to the lack of a possibility of legal activity. Newspapers and leaflets which were distributed by dumping from the plane not always got there where they were most necessary. The guerrillas had to make leaflets for distribution among the local population.

Thus, information and ideological opposition between fascist Germany and the Soviet Union was not less powerful and significant, than armed struggle. At the level of information space, there was a fight for influence on soldiers of the Red Army and the population of the territories of Ukraine occupied by the fascist army. Informational opposition amplified counter180 
propaganda from nationalist forces, in particular, OUN, UPA and considerably weakened positions of both parties. Both Hitler's occupational administration and soviet leadership applied all methods, means and methods of information fight possible at that time, resorted to various dirty technologies, often discrediting themselves. Both opponents intimidating the population and promising it the desirable, used aspiration of the Ukrainian people to peaceful work and creation of own state. The severe morale psychological state of the population of "Reykhskomissariat Ukraine" and zones of military authorities became a consequence of information opposition of Nazi Germany and the Soviet Union. It was formed in the conditions of difficult military opposition between Nazi Germany and the Soviet Union. Difficult financial and economic situation of the population of the occupied areas had a great influence on it that led to the aggravation of a number of social problems.

Political passions of the most part of the population of occupied territories shared between three main forces, had opposite views of a political situation which developed. One part of the population was suppressed and did not represent the future under Nazi occupation, another - small frank hoped that the new power would bring a contribution to the development of the Ukrainian society and revival of culture. The third part of population would like to live in the independent Ukrainian state promised by Nazi power. Big regional differences were also peculiar to political sympathies. In the East, as it was already noted, a certain part of the population stood in opposition to occupational administration, cooperated with guerrillas and underground workers; in the West, where liberating traditions were still alive, the population, the intellectuals and peasants, wished for restoration of own state and solution of the land question.

The great influence on consciousness and moods of the population of Ukraine made carrying out within the 30th years of the policy of "military communism", violent collectivization, mass repressions, cultivation among the population the concept "enemy of the people" and prosecutions of all who fell under this category (Куманев, 2005, 143).

The events which were taking place in 1941 became the tragedy of improbable ranges that put the people and the Soviet Union on the edge of a chasm. The German tank columns which were followed by motor-infantry and were supported by aircraft managed to do irreparable harm to the Soviet troops in a short time. It is necessary to tell the German plans of fighting were implemented with some advancing. So, it was planned that boundary fights will last not less than four weeks (Загорулько, 1980, 7). By information, which Ukrainian historian V. Y. Korol gives us... "they ended in favor of the German 
side by July 10. In total for the first three weeks of war the Red Army lost 850 thousand soldiers, nearly 3.5 thousand planes, over 6 thousand tanks, 20 thousand mortars. Catastrophic defeat received more than 100 soviet divisions. Germans took away a half of the warehouses located in the territory of these districts including strategic importance. Germans took in warehouses 5400000 from a total 7600000 rifles. 191 thousand from a total of 240 thousand machineguns. It became the captivity reason of 329 thousand soldiers and commanders in the first two weeks of the war" (Король, 2001, 5).

The consequences of the first fights happened to be obvious because famous Soviet specialists engineers, officers of the Red Army were repressed even on the eve of war. In the first months of war to arrange production of new planes, specialists prisoners who were not managed to be shot or tortured yet were brought together in special scientific center-TsKB-29 where worked the famous aircraft designers and engineers - "enemies of the people" A. Tupolev, D. Tomashevich, R. Bartini, V. Petlyakov (about 30 people including from Ukraine) (Король, 2002, 14). Most of the minds of the large industrial enterprises in Ukraine were also repressed including the management of Azovstal, Krivorozhstal and others. It led to the fact that the majority of progressive engineering developers including the military sphere were not placed at production. Repressions on the West Ukrainian lands, the deportations of the civilian population which were carried out by the Soviet power led to the fact that a part of the population of Ukraine did not wish to struggle with aggressors. Therefore along with heroism of the Soviet people cases of panic escape from the battlefield of the whole military divisions of the Red Army were observed. (Костенко, 2002, 39). One more important aspect which influenced the population of occupied territories was forced the withdrawal of the Soviet troops Receding, the Soviet troops made an awful impression. Without any control, without observing leaving tactics, fighters mixed up broke into separate groups of badly armed, demoralized people who tried to leave. Not all managed it, but the majority that got on the territories occupied by the German army lost any hope and trust to soviet leadership.

The trust to Soviet leadership was lost also by inhabitants of temporarily occupied territories, in particular, Kyiv where after the withdrawal of "Bolsheviks", in cellars of People's Commissariat for Internal Affairs several hundreds of disfigured corpses with shot wounds were revealed, injured by something heavy. Among them, locals recognized the Ukrainian engineers, actors, famous in Kiev, etc. No less terrible spectacles were seen in the "Lukyanovsky prison" and in other premises of Kiev. There a large number of corpses of the tortured people were found. Not less awful events followed 
evacuation and of other cities. Some days before Odessa invading all criminals were released.

The last two-three days prison was protected by the strengthened groups of "People's Commissariat for Internal Affairs". "In the middle of the prison, there was some vanity. For the second day after the entry into the city of the Romanian army in numerous cellars of prison was revealed a large number of corpses" (Пігідо-Правобережний, 2002, 105, 107). When Germans found cruelly killed people they showed them to locals as the eloquent proof of the Soviet policy. It did not add the authority to the Soviet power.

A week after the beginning of the war, the considerable territory of Western Ukraine was occupied. Residents of these lands were confused and therefore the first had to adapt to new conditions. In the "Report of the 213th Security Division of Wehrmacht" of July 27, 1941 it was said that the Ukrainian population of the West Ukrainian lands at first apprehended arrival of the German troops as a relief from "Bolshevist" domination. Polish population also not refused to cooperate with the new power. But later the situation changed. Doctor of Historical Sciences of the Sorbon University (Paris) and Ukrainian Free University (Munich) Vladimir Kosik in the researches explains that Ukrainians had a long-awaited opportunity and conditions for the creation of own authorities and security. According to Nazi invaders, their political "will" began "to wake up". At first, Ukrainians really showed readiness for cooperation with the German authorities. But over time, when the German troops moved ahead further in occupied territories and decreased, the aspiration of the population of Western Ukraine to independence raised more. Most brightly this desire was shown at residents of such cities as Lutsk, Rivne, Kovel, Ostrog, etc. The same V. Kosik noted that after "Germans decided not to allow Ukrainian to make autonomy in General Governorship", they met rather serious difficulties in the relations with the population of the Western Ukraine, but "in East direction territories from the Soviet-Polish the population in the first weeks of war accepted Germans as liberators" (Косик, 1998, 181-182).

The important role in moods of civilians of the most part of the Ukrainian lands played "agrarian question" and the policy of the occupying authorities in the agricultural industry. Most of the peasants were hostile in relation to the German authorities in the first months of war and showed readiness for cooperation. A considerable part of Ukrainians expected that Germans wiould bring improvements in social life. Also, increased people agreement with proclaimed private property law (Ніколаєць, 1999, 44-45). Innovations of enemies in the sphere of agricultural industry were not always approvingly perceived in all territory of Ukraine. For example, in the territory of Donbass 
the German agrarian reforms met huge mistrust. The following was the main argument in this case: "Communists promised us so much, and so often deceived us, and Germans also only promise" (Ніколаєць, 1999, 54).

Political moods of the Ukrainian intellectuals in the occupied territory were not a less important factor. The analysis of agents special messages of "People's Commissariat for Internal Affairs" in the years of war allow to draw a conclusion of political moods in scientific, technical and creative layer. Intellectuals that already divided at the beginning of the war in two categories. Those who loyally treated the Soviet power and those who became puzzled from constant losses and starving.

Great efforts were required to the leadership of the USSR to recede from the administration mainline, about the leading role of the Russian people and to proclaim that the Soviet people were the citizens of the multinational state. At the same time, the country leaders urged Ukrainian and other people to protect the "Motherland" and its achievements. The reaction of the population of occupied territories to such changes in the policy of Soviet leadership was different. The behavior and political views of people depended on many factors: territories of accommodation, age, education, life experience, etc.

Most of the population of the" Left bank of Ukraine was loyally adjusted to the Soviet power. Most of the locals did not expect change from the German authorities, but at the same time, each person had own feelings, the aspirations which influenced his relationship to the events happening on the front line and the areas of Ukraine occupied by the fascist army. Each person had a miscellaneous attitude towards the enemy and to the Soviet power In the first days of war the resident of Kiev Anna Trukhan wrote in the letter to the son: "You can give that feeling of hatred to German clique which started this war... Firmly I believe in the wise leadership of our country. I'm happy that I could grow up the defender - you, the sonny. Be quiet, firm, you know well what to protect..." (Рибченко, 2008, 252).

Such mood of the woman was explained by the existence of ideological stereotypes. All life she faithfully worked for a "Bolshevist system" and trusted in its strong ideals which she gave to the son.

But among inhabitants of the "Left bank", there were those who after the withdrawal of the Soviet troops had absolutely other feelings. Among them there was a writer Arkady Lyubchenko who was pursued more than once by People's Commissariat for Internal Affairs after the withdrawal of the Soviet troops. He noted: "It was feeling of freedom, independence. There are no meetings, plenums, conferences... It is not necessary to hurry anywhere - you are free. It is not necessary to report, does not prevail over you awful despotic and bureaucratic fists - you are free! Nobody interferes with your private life, 
do that you want and as you want. Free! Nobody watches you though. But still, as a habit continue to look around, speak with lowered a voice, uncertainly, as the conspirator. Long-time I did not believe that it is already another reality, I can dispose of myself and the time as I want. Very pleasant feeling!" - he wrote in the diary (Рибченко, 2008, 253). Such feelings were short. As soon as the German administration began to show the true intentions, to kill people in large quantities, to send youth violently to Germany, to force to work for the sake of the "Third Reich", etc., people began to understand a true essence of activity of the Hitler's authority, and with it and to get rid of free life hopes and future welfare of the family and Ukraine.

From the report of the Minister of Foreign Affairs of Germany from August 31 till September 15, 1941, about a political and economic situation in Ukraine we see that the population of the Ukrainian SSR did not show a big political activity. Only an insignificant part pins hoped for the arrangement of the Ukrainian territory on arrival of the German army. In the report, it was also noted that Ukrainians expected, first of all, improvement of the financial position, realizing in what awful poverty they lived earlier. The population of "Eastern Ukraine" also did not show resistance. Moreover, the "Wehrmacht2 was satisfied with the support of the local population in the organization of public life and local authority (Косик, 1998, 322).

Change of a situation at the front and in moods of the population of occupied territories was confirmed by the Report No.191 of the Chief of the "Security Police and Security Service" ("SD") on events in the USSR. The report defined the heterogeneity of the local population mood. It was shown that the Ukrainian intellectuals and student's youth gathered hoping for the future independence of Ukraine. It should be pointed out the characteristic fact that a considerable part of the population did not have enough belief in a final victory of Hitler's Germany over Soviet. They waited for a breakdown in the confrontation of two sides in order Ukraine would become independent. As far as a rural population the question about the "Land law" was in the first place. Political problems interested them much less. The population of the Central and Eastern Ukraine more depressed by the shortage of food and a question of survival in the conditions of occupation. In this part of Ukraine, a large number of the Soviet activists blowing up the power of the German administration which had not fixed on places yet.

The negative attitude of the local population to the occupying authority since the end of 1942 had been caused also by the destruction of their housing and personal plots. The greatest damage to a dwelling stock was caused in villages of Left-bank Ukraine. So, in 197 areas from 10295 rural settlements, 
the fascist power burned and destroyed 6226 country estates. Destruction of countryside estates was caused by a variety of reasons: The discontent of peasants who arose because of robberies and violence, the manifestation of disobedience from the local population, a failure to follow orders of occupational administration, evasion from labor service, departure to Germany and many other things (Перехрест, 2005, 138-139).

The occupational policy of a Nazi government during this period was shown in two directions: robbery of the local population and its operation; the exile of people from own houses and their mass export for work in fascist Germany. On "East lands", during 1942 all population: old men, women, pupils of schools were mobilized for forced labor. Corporations and factories made products only for Germans. Officers occupied places of the Ukrainian citizens and took them to hard work in Germany. It revolted the local population very much. People, as soon as could, evaded from sending for forced labor, disappeared, ran in guerrilla groups. The Ukrainian children peeled and hungry, wandered through the streets, and children of ethnic Germans - went out of town rest. The population was hostile to the Germans (Сергійчук, 2005, 54-55).

Miscellaneous was a moral and psychological condition of the population of Donbas, Poltavshchyna, Dnepropetrovshchina, Voroshilovgradshchina and the Kharkiv region. Not all Soviet citizens of this region of Ukraine believed that the German authorities wouldl bring long-awaited freedom and independence of Ukraine. The situation was complicated also that the Soviet power continued to pursue political prisoners, and from the beginning of war began to shoot them. The number of death penalties to political criminals sharply increased from 1649 people in 1940 up to 9011 people in 1941 and 23278 people in 1942. (Попов, 1992, 28).

According to the "Guerrilla groups", the moral and psychological condition and mood of the population of the Rivne, Zhytomyr and Kiev regions were such that the most part of the population looked forward to the Red Army. Even those who at the beginning of war waited for the arrival of the German army damned it and were ready to cooperate with guerrillas to bring closer arrival of the Soviet troops (Центральний державний архів вищих органів влади та управління України. Фонд, 72).

During the war, both soldiers and civilians suffered from terror of two sides. "About 8000000 Soviet servicemen and 20000000 civilians were killed, died of diseases, hunger and other reasons connected with war" (Шевьяков, 1991, 9-10).

The moral and psychological condition of the population was influenced also by the policy of Hitler's Germany and occupational administration by training 
and culture. At the first months of the attack, the occupational administration opened initial educational institutions, various professional schools, gymnasiums and other educational institutions but the real policy of Nazis was shown in November-December, 1941 (Добров, Бистра, 2003, 57-58).

The real aspiration and plans of fascist Germany on educations of the Ukrainian population were quite reflected in Hitler's words that "the general education is decomposing poison. Everyone will have their own education level. Broad masses of slaves would blessed to be illiterate" (Ноэль-Нойман, 1996, 13).

The policy pursued in temporarily occupied territories by Hitler's administration led to the fact that in all territory of "Reykhskomissariat Ukraine" and in a zone of military authorities began closing of all educational and educational institutions, stage-by-stage restriction of intellectual potential of the population of Ukraine and its opportunity to receive through some education. According to the historian Y. Y. Gritsak, during the German occupation in the territory of Ukraine 32930 schools, professional schools, technical schools, higher educational institutions and research institutions, 19200 libraries were destroyed and plundered. The majority of literature was taken out to Germany - 50 million. Books (Грицак, 1996, 30).

With the arrival of the fascist army on the territory of Ukraine and "Reykhskomissariat's Ukraine" the occupying authority allowed and even encouraged opening of the educational organizations, theatres and museums. It was caused by a variety of reasons. First, theatre put performances for the German soldiers, and, secondly, it was one more mechanism of dissemination of information among the population about helpful German state and its administration. Theatres were often used as the place for messages and the announcement of various resolutions and orders of occupational administration. Besides the loyal policy of Hitler's leadership to the Ukrainian theatrical activity, authorized commissioners carried out constant actions for inspection of actors and production directors on political reliability. As a result of such actions not only educational institutions but also theatres headed by the loyal to "new order" authorities. Most of the population watchfully treated visits to the theatre, tried to avoid them more often. Theatres in Zhytomyr, Sumy, Konotop, Dnipropetrovsk, Nezhin, Chernihiv, Mariupol, Kharkiv, etc. which worked in the first months of the Great Patriotic War in November-December, 1942 began to be closed or used only for Germans.

It was proved by publications in the monthly propaganda edition of OUN "Vilna Ukraina". In the article "Across Ukraine" which appeared on September 8, 1943, it was noted that "the German terror did not stop. Germans burn down villages. It is burned northern areas of Kyiv region. Lately, Hitler's government in Kyiv destroyed all manifestations of the 
Ukrainian culture, all monuments... Cultural and educational life almost does not exist. Theatres and cinemas keep the German shelves only to catch the local population and to send to Germany...". A similar situation took place in Kirovohrad, Dnipropetrovsk, Kamyanets-Podilsky and in Lutsk (Державний архів Рівненської області, 14-15). Bright picture of the real cultural policy of the German occupational administration and its influence on a moral and psychological condition into the Ukrainian population was shown also in the brochure of OUN "For Independence". Here we read that in Kirovohrad cultural life faded. Newspapers appeared only in places of "Gebitskomissariat". The Ukrainian intellectuals, students and youth of school age which were not taken out to Germany had to be expelled for work. The work mode was toughened, frequent audits of food and reserves of grain were carried out.

The activity of occupational administration led to the fact that a considerable part of residents of the occupied areas began to think and compare the Soviet mode to existing. It directed to that Ukrainian citizens began support of Guerrilla movement. The "Nationalist Organizations" began the open fight against the occupying authority and troops of "Wehrmacht". In spring of 1942 in the Polesia forests of Rivne there were first paramilitary groups which would act as the Ukrainian Insurgent Army (UIA). Generally, in this military organization, there were active participants of the Ukrainian liberation movement and youth which threatened for work to Germany (Поліщук, 1998, 152-153).

Reports of propaganda of battalions analyzed the population attitude to religion, that the occupying authority created favorable conditions for activity of all faiths and received the favor of local population (Титаренко, 2005, 168-169). The revival of religiousness of the population of Ukraine under Nazi occupation was explained by the fact that at the time of political and economic problems when the faith in the power was lost, the person needed to hope for himself or for God. It was quite natural that in the conditions of Nazi occupation and hope for protection from the Soviet power people even more often began to address God. It should be noted that religious liberty of inhabitants was possible for two main reasons: tolerance towards believers from the German authorities and partial liberalization in the field of religious policy from the Soviet power. Except for the main faiths, during the German occupation actively began to carry out the promotion among the population various religious trends which activity was banned earlier. The historian, Y. Zinko claimed that revitalization of religious life, especially "Protestant Christian Communities" became an important consequence of the war in the USSR and Ukraine. (Зиновьев, 1991, 251). Representatives of various 
religious trends carried out own promotion among the population. It was frequent even without the intervention of the occupying authorities. In the mentioned already German "Instruction on questions of carrying out the German policy in Ukraine". It was said that in questions of religion it was necessary to show tolerance (Муковський, 1996, 54). Church attendants had an opportunity to begin the process of revival of religion.

"Reykhskomissar of Ukraine" E. Koch influenced religious processes in Ukraine published the order which consisted of plans for separation "Orthodox Church" into several confessional associations.

Adhering on the religious controversy he ordered that the Ukrainian autocephalous church being under Influence of "UAPT" should be supported. For years of Soviet power it was completely destroyed. In period of Nazi occupation the autocephalous church was restored gradually. In Western Ukraine a certain part of clergy and believers, especially Greco-catholic, supported the idea of creation of the Ukrainian state. Hoping for the support of the occupying authority metropolitan A. Sheptitsky addressed on July 5, 1941 clergy and believers with the letter: "At will of the Almighty and Gracious God a new era begins in the life of our Motherland. We welcome the invincible German army which had occupied already the whole edge with pleasure and gratitude for liberation from the enemy. Everybody who feels Ukrainian and wants to work for the benefit of Ukraine let's forget about any dismantling". Lets work in unity and consent on the restoration of destroyed by "Bolshevik's our economic, educational and cultural life" (Вільне слово, 1941, 1). Similar moods dominated also among Autocephalous Ukrainian clergy at this time.

The youth who were sent to Germany incited against the German occupational policy. The assistant commissioner of the Sumy's Guerrilla Komsomol organization wrote in the report that the youth was disappointed in the occupying authority, nearly one and a half year it was forbidden to gather, sing the Ukrainian songs, to dance national dances, to speak loudly. With great desire, they came to evenings and discussions which were led by guerrillas, listened about achievements and victories of the Soviet Army (Центральний державний архів вищих органів влади та управління України, 180-183). As a result of such policy, a considerable part of youth ran away to guerrillas and participated in performances against Hitler's army, realizing consequences of Nazi domination on the Ukrainian lands.

Peasants were undeceived that agrarian reform would be undertaken and they were revolted that their land and property again were given to the new owners. On the general order No. 1 of July 9, 1941 collective-farm the cattle, cars, the arable land transfer to the German occupying authority. Besides, all 
collective-farm property, peasants managed to stretch after the departure of the Red Army. It was demanded to return to appropriate authorities (Центральний державний архів вищих органів влади та управління України, 131-132). Awful situation and hopes of peasants for the better life, independent managing which was scattered in ashes became a reality of life. That time they ignored instructions of the German administration, A thicket helped guerrillas and waited for the arrival of the Soviet army.

At the beginning of 1942 position of the Ukrainian peasantry in the territory of "Reykhskomissariat Ukraine" and moods of the population worsen. The occupying authority felt strengthening of resistance. Most of the population was dissatisfied with the policy of the German occupational administration because of the increase in the prices, frequent arrests in the cities, sending workers to Germany, the shortage of food. In the German report of May 31, 1942, it was noted that in Eastern Ukraine the population actively showed the discontent and even more often it was possible to hear the words of damnation towards the German occupying authority (Косик, 1998, 233).

Considerably the moral and psychological condition of the local population in the fall of 1943 worsened. From the report of the commander of "Security troops" to the commander of the operational rear region of a group of "The South" armies of September 4, 1943, we know about worsens moods of the population. By the end of 1943. - beginning of 1944 resistance of the local population to the occupying authorities amplified. The youth which forced to go to Germany run away to forests. The orders of local administration were not carried out (Історія застерігає, Трофейні документи про злочини німецько-фашистських загарбників та їхніх пособників на тимчасово окупованій території України в роки Великої Вітчизняної війни, 1986, 151-152). From the information report of "OUN" in Kirovogradshchina, Nikolaev and Umanshchina in the fall of 1943 we learn that most of the population was adjusted bolshevism. However, they were afraid of the approach of the front and evacuation in Living in a moment. The fear of the German repressions was more than in other territories. In villages, many disappeared and did not go to Germany. Lots of talks about guerrillas, however, were not always favorable (Сергійчук, 2005, 301).

Analyzing a situation which developed at the beginning of the Great Patriotic War, it is necessary to tell that short-sighted policy of the Stalin mode within which genocide of own people was carried out led to the fact that from the beginning of war against Nazi Germany, the Soviet people showed mistrust to the Soviet power, but also there were not mass actions against Hitler's. 
By the end of 1941 beginning of 1942 Stalin and Soviet government understood the need for special information space in the territory of the USSR, on occupied territories. What would convince the population that only the Soviet leadership was be able to create necessary conditions for a victory against the fascist army and development in the future of the state? Soviet leadership managed to create such information space thanks to which actually the victory also became indisputable. Fight of two conflicting military opponents led to considerable pressure upon a moral and psychological condition of the population of occupied territories. Therefore, the behavior of inhabitants of "Reykhskomissariat Ukraine" and zones of military authorities was different.

The problem of effectiveness of German propaganda is considered to be extremely important. Influence of the German propaganda was during certain periods of war and in different territories of occupied Ukraine. Strengthening or weakening of influence depended on the activity of the Soviet propaganda. Impact on the consciousness of ordinary Ukrainian depended on what attitude to the Soviet power he population of the occupied territories expressed during the pre-war period.

It is difficult to define the influence of information space quantitatively. It is rather behind the morale of the population, physical and a sort of their occupations. The Western Ukraine population the intellectuals and military caring had the idea of creation of the independent state. They were ready to cooperate with Nazi invaders. Rather Central and East regions, the intellectuals only partially supported the occupying authorities trying to survive somehow under trying conditions. The rural population underwent the influence of Nazi propaganda only because believed in the destruction of a collective-farm system, receiving own ground and opportunity to have an independent economy. It seemed to be an absolutely insignificant part of the population that Germany as the European country would help Ukraine to lift economic and social development and to lift culture to a high level. A certain part of the Ukrainian society, really, cooperated with the German occupational administration. It is known that in each settlement there was created Ukrainian auxiliary police. Its main objective was the organization of laborers and supervision of it, direct participation in executions. Ask ourselves a question. Is there any population in the world which during war did not cooperate with the purpose of protection of own life or maintaining statehood during war?

If you turn to address Jewish documents showing the position of Jews, they can confirm the participation of Ukrainian in punitive actions. It is not confirmed by indications of the "Ynzattsgruppa" operating in Northern and Central Ukraine. In the territory of "Reykhskomissariat Ukraine" in one of the 
reports, it was noted: "almost anywhere the population was not involved in actions against Jews". In another report it was written that "the population almost has no anti-Semitism and racist ideological character" and "that for repressions against Jews the Ukrainian population lacks leaders and a spiritual heat" (Косик 1998, 157).

Summing up, it should be noted that the influence of the German information space on the population of occupied territories was huge. It is proved also by measures which were applied by the Soviet power in the freed territories. "Regional committees of the Communist Party" of Ukraine undertook to restore a cultural and educational network of institutions in the shortest possible time, earlier functioned in the territory of the Ukrainian SSR. 2Regional committees" trained lecturers and speakers on gatherings of youth. Active work among pupils of schools and factory educational institutions was carried out. In those areas where recently there were German periodicals there was adjusted issue of large-circulation Soviet newspapers that period.

\section{REFERENCES}

1. Король В.Ю. 2002. Трагедія військовополонених на окупованій території України в 1941-1944 роках. Київ: Видавничий центр “Академія".

2. Daugherty W., Janowitz M.A. 2001. Psychological Warfare Casebook. Berlin.

3. Панарин И.Н. 2006. Информационная война, PR и мировая политика. Москва : Горячая линия “Телеком”.

4. Невежин В.А. 2007. Если завтра в поход... Москва : Яуза, Эксмо.

5. Невежин В.А. 2003. Застольные речи Сталина. Документы и материалы. Москва : АИРО-ХХ; Санкт-Петербург: Дмитрий Булат.

6. Жуков Г.К. 1985. Воспоминания и размышления. В 3-х т. Т. 1. Москва : Агенство печати "Новости".

7. Секреты Гитлера на столе у Сталина. 1995. Разведка и контрразведка о подготовке германской агрессии против СССР. Москва : Политиздат.

8. Военно-исторический журнал. 1995. № 2.

9. Григоренко П. 1981. "В подполье можно встретить только крыс...” Издательство “Детинец”. Нью-Йорк.

10. Панарин И.Н. 2006. Информационная война, PR и мировая политика. Москва : Горячая линия “Телеком”.

11. Невежин В.А. 2007. Если завтра в поход... Москва : Яуза, Эксмо.

12. Balfour Michael. 1979. Propaganda in War 1939-1945. Organisations, Policies and Publics in Britain snd Germany. London, Routledge \& Kegan Paul. 
13. Панарин И.Н. 2006. Информационная война, PR и мировая политика. Москва : Горячая линия «Телеком».

14. Окороков А. 2007. Особый фронт. Немецкая пропаганда на Восточном фронте в годы Второй мировой войны. Москва: Русский путь.

15. Гитлеровская пропаганда юдофобии в прокламациях и карикатурах 2005. Автор и составитель Авербух С.Л. Киев: Украинский Центр изучения Холокоста.

16. Центральний державний архів вищих органів влади та управління України Фонд. 4620 Оп. 3. Спр. 97.

17. Советская пропаганда в годы Великой Отечественной войны: «коммуникация убеждения» и мобилизационные механизмы 2007. Авторы и составители Лившин А.Я., Орлов И.Б. Москва : Российская политическая энциклопедия.

18. Сборник законодательных и нормативных актов о репрессиях и реабилитации жертв политических репрессий 1993. Москва : Издательство Верховного Совета РФ.

19. Безыменский Л.А. 1981. Разгаданные загадки Третьего Рейха, 1933-1941: Книга не только о прошлом. Москва : Издательство агенства печать "Новости".

20. Білас І.Г. 1994. Репресивно-каральна система в Україні. 19171953: Суспільно-політичний та історико-правовий аналіз: У 2 кн. Кн. 2. Київ : Либілдь - Військо України,

21. Центральний державний архів громадських об'єднань України. Фонд 1. Оп. 22. Спр. 53.

22. Центральний державний архів громадських об'єднань України. Фонд 1. Оп. 22. Спр. 26.

23. Никулина, Н.Ю., Сорока 3.Н. 1999. Советское Информационное Бюро в годы Великой Отечественной войны (анализ источников). Проблемы источниковедения и историографии. Калининград: Калининградский государственный университет.

24. Мельтюхов М.И. 22 июня 1941 г.: цифры свидетельствуют 1991. История СССР. № 3.

25. Бутырин О. 2006. Хронология войны в ежедневных информационных сводках / О. Бутырин. Москва : Мысль.

26. Всенародное партизанское движение в Белоруссии в годы Великой Отечественной войны (июнь 1941 - июль 1944). 1973. Документы и материалы В 3 т. Минск: Беларусь. Т. 2.

27. Центральний державний архів вищих органів влади та управління України Фонд. 4620. Оп. 3. Спр. 100. 
28. Центральний державний архів громадських об'єднань України. Фонд 1. Оп. 70. Спр. 12.

29. Шверник Н.М. 1943. Год Всесоюзного социалистического соревнования. Москва : Профиздат.

30. Центральний державний архів громадських об'єднань України. Фонд 1. Оп. 70. Спр. 10.

31. Чайковський А.С. 1994. Невідома війна (Партизанський рух в Україні 1941-1944 pp. мовою документів, очима історика). Київ : Україна.

32. Центральний державний архів громадських об'єднань України. Фонд 57. Оп. 4. Спр. 214, 225, 229.

33. Центральний державний архів громадських об'єднань України. Фонд 62. Оп. 1. Спр. 1627.

34. Wipperman W. 1989. Der konsequente Wahn. Ideologie und Politik Adolf Hitlers. Muenchen. München: Bertelsmann-Lexikon-Verl.

35. Центральний державний архів вищих органів влади та управління України. Фонд 4620. Оп. 3. Спр. 128.

36. Центральний державний архів громадських об'єднань України. Фонд 1. Оп. 22. Спр. 22.

37. Центральний державний архів вищих органів влади та управління України. Фонд 4620. Оп. 3. Спр. 106.

38. Центральний державний архів громадських об’єднань України. Фонд 57. Оп. 4. Спр. 185.

39. Партийное подполье в Белоруссии. 1941-1944: Страницы воспоминаний1984. Минская область и Минск. Минск: Издательство "Минск".

40. Ивлев И.А., Юденков А.Ф. 1988. Оружие контрпропаганды, Советская пропаганда среди населения оккупированной территории СССР. Сборник материалов. Москва : Мысль,

41. Куманев Г.А., Юденков А.Ф. 2005. Говорят сталинские наркомы. Смоленск: Русич.

42. Король В.Ю. 2001. Трагізм 1941-го року. До 60-річчя початку Великої Вітчизняної війни. Історія в школі, № 7.

43. Костенко Ю. 2002. Морально-психологічний стан Червоної армії в ході перших боїв (червень 1941 р.). Київ : Воєнна історія. № 3-4.

44. Пігідо-Правобережний Ф. 2002. Велика Вітчизняна війна. Київ : Смолоскип.

45. Косик В. 1998. Україна Другій світовій війні у документах: Збірник німецьких архівних матеріалів. Львів: Львівський національний університет ім. Івана Франка. Т. 2. 
46. Ніколаєць Ю.А. 1999. Становище та настрої населення України на початку німецько-фашистської окупації: [червень 1941 - липень 1942 рр.]. Вінниця: Тезис.

47. Пігідо-Правобережний Ф. 2002. Велика Вітчизняна війна. Київ : Смолоскип.

48. Костенко Ю. 2002. Морально-психологічний стан Червоної армії в ході перших боїв (червень 1941 р.). Київ : Воєнна історія. № 3-4.

49. Рибченко Л. 2008. Визволених територій Лівобережної України у 1941-1943 рр. Український історичний збірник. Рада молодих вчених. Вип. 11. Київ : Інститут історії України НАН України.

50. Допрос подсудимого Шпеера. 1946. Из стенограммы заседания Международного Военного Трибунала от 21 июня 1946 г. Доступ 16 жовтня 2019: http://historic.ru/books/item/f00/s00/z0000021/st018.shtml

51. Перехрест О.Г. 2005. Нищення житла в українському селі в період німецько-радянської війни 1941-1945 pp. Сторінки воєнної історії України: Збірник наукових статей. Вип. 9. Част. 3. Київ : Інститут історії України НАН України.

52. Сергійчук В. 2005. Український здвиг: Наддніпрянщина. 1941-1955. Київ : Українська Видавнича Спілка.

53. Попов В.П. 1992. Государственный террор в Советской Росии. 1923-1953 гг. (Источники и их инрпретация). № 2. Москва : Отечественные архивы.

54. Центральний державний архів вищих органів влади та управління України. Фонд 4620. Оп. 3. Спр. 100.

55. Шевьяков О. 1991. Гитлеровский геноцид на территориях СССР. Социологическое исследование. № 12. Москва: Социологический вестник.

56. Добров П.В., Бистра М.О. 2003. Національний компонент в політиці німецько-фашистської окупаційної влади на території України у галузі освіти. Історичні i політологічні дослідження: Матеріали IV Міжнародної наукової конференції молодих вчених та студентів «Нації та національні відносини в історії людства очима молодих дослідників» Донецьк : Видавництво ДонНУ. № 2(14).

57. Ноэль-Нойман Э. 1996. Общественное мнение: открытые спирали молчания. Москва : Пресс-Академия.

58. Державний архів Рівненської області. Фонд Р-30. Оп. 1. Спр. 25.

59. Титаренко Д. М. 2005. Звіти батальйону пропаганди U як джерело 3 питання про вплив нацистської пропаганди на населення окупованої України. Друга світова війна i доля народів України: Матеріали Всеукраїнської наукової конференції. Київ : Наукова думка. 
60. Зиновьев А. 1991. Гомо советикус. Москва : Московский рабочий. 61. Вільне слово. 1941.9 липня.

62. Центральний державний архів вищих органів влади та управління України. Фонд 4620. Оп. 3. Спр. 106.

63. Центральний державний архів вищих органів влади та управління України. Фонд 4620. Оп. 3. Спр. 97.

64. Історія застерігає. 1986. Трофейні документи про злочини німецько-фашистських загарбників та їхніх пособників на тимчасово окупованій території України в роки Великої Вітчизняної війни. Упорядник В.М. Нем'ятий. Київ : Видавництво політичної літератури України. 


\section{CONCLUSIONS}

Summarizing, it should be noted that the formation of the German information space in the territory of the Reich Commissariat "Ukraine" and in the area of military administration and its transformation took place in three stages, which were very different from each other.

In the initial period from June 1941 to March 1942, when Hitler's leadership realized that the war with the USSR would be complicated and long-lasting, the Nazi information policy aimed at convincing the population of the occupied regions of Ukraine and nationalist Ukrainian groups that the German war was over liberation from Bolshevik rule. Admittedly, she has had some success during this period. Some peasants and intellectuals believed that it was thanks to Germany that Ukraine would free itself from the Bolshevik regime and be able to independently build its own state and develop Ukrainian culture. The peasants were waiting for a solution to the painful land issue, and that is why the "agrarian reform" promoted by the Hitler administration attracted a large part of the peasants. During the same period, the occupation authorities created favorable conditions for the activities of the intelligentsia: educational institutions operated; theaters were opened showing performances of works by Ukrainian writers, mainly those whose works were banned in Soviet times; cultural and educational organizations were created and operated, including "Prosvita", in almost every oblast, district or city periodicals were published. In the press and cinematography, Nazi Germany was positioned as a highly developed cultural country, and so in the first months of the war there were willing people among the local population who went to the Reich voluntarily. A small part of the population, under the influence of Nazi propaganda and their own ideas about preserving their lives and the lives of their family members, deliberately went to cooperate with the German occupation administration.

Significant changes in the information policy of the German occupation power occurred in the second period - March-April 1942 - when the situation on the fronts for the German army worsened, the propaganda activities of representatives of the resistance movement, nationalist military groups increased. The German authorities immediately intensified the occupation regime, persecuting all those suspected of cooperating with the guerrillas, who did not want to go to work in Germany, who sabotaged the orders and orders of the local authorities, and so on. During this period, the propaganda slogans of Hitler's power changed dramatically. They no longer promised a happy life in their own state, no word was heard about the implementation of the 
"agrarian reform"; instead, educational, cultural and educational institutions were closed; the theaters worked mainly to entertain the Wehrmacht and the Volksdeutsche, became frequent raids in theaters and cinemas by locals and young people for forced labor in Germany, and increased violence with the locals as a result of the destruction of German soldiers and guerrillas. This situation could not leave people indifferent. The moral and psychological condition of the population was extremely difficult, the moods among the locals changed and people began to support the guerrillas and participate in the resistance movement organized by the OUN and UPA and the Soviet guerrillas. The main topic of German propaganda at this stage was the intimidation of local residents by punishment for cooperation with the guerrillas and the Soviet authorities. Despite the fact that since May 1942 the German army had been defeated by the Red Army, the newspapers maintained an optimistic mood among the population through reports of the benefits of the German army, the loss of the Soviet Army, and the defeat suffered by USSR allies on all fronts of the world.

The third period of information policy of Hitler's Germany was accompanied by difficult military and political conditions - defensive battles of the German army. Since the summer of 1943, under the pressure of the Red Army and as a result of the subversive activities of the guerrilla units, the Nazi leadership had to change its tactics and information policies on the territory of the Reich Commissariat of Ukraine and in the area of military administration. The content of the propaganda was filled with slogans calling on the local population not to respond to the guerrillas' calls for support of the Soviet authorities, in periodicals and leaflets it spoke about the massacre of the Bolsheviks with prisoners of war and their families, with those who remained in the occupied territories, in the occupied territories will be denied the opportunity to work on their own land, etc. In particular, the activity of the occupying power on the deployment of "agrarian reform", which had long been promoted by the German authorities but had not been implemented, intensified. In 1944, retreating, the Nazi troops urged the population of the Reich Commissariat and zones of the military administration to destroy all farms and retreat with the Wehrmacht troops.

The formation of the German information space in the occupied territories of Ukraine was accompanied by counter-propaganda by the Political Directorate of the Red Army. The Soviet leadership also applied methods and means of informational influence on the personnel of the German army and the population of the occupied territories.

The information-military confrontation between the two warring parties led to considerable pressure on the moral and psychological situation of the 
occupied territories, so the reaction in the behavior of the residents of the Reich Commissariat of Ukraine and the zone of military administration was different. Much of the population was oppressed by the new regime and held a passive expected position, others went to guerrilla units and promoted and subversive activities among the local population - among the occupying German officials.

Under the influence of Nazi propaganda and in the circumstances, most Ukrainians were forced to obey the invaders and passively obey German orders. However, a small part of the population actively, consciously cooperated with the invaders, and today historical science calls this phenomenon "collaboration." At that time, this phenomenon was quite clear. Most of the Ukrainian collaborators were mostly USSR citizens, repressed by the Soviet authorities. However, there were not many of them than among the Russians or other nations of the occupied countries.

In our view, the reasons for supporting part of the population of the Nazi occupying power were also the desire to at any cost free themselves from the Soviet regime and the collective farm system, which deprived the Ukrainians of all that they had.

In spite of the powerful information policy and active propaganda, the information space formed by Hitler's leadership was weakened by the brutal and careless policies of the Nazi administration in Ukraine. In pursuing a powerful information policy, the occupation administration could not hide the crimes it committed against the Ukrainian, Russian, Jewish, Roma, Tatars and other national minorities. This further increased the resistance of the local population against the occupying power. It should also be noted that Hitler's German policy toward the Slavic peoples was a major factor influencing the population of the Reich Commissariat of Ukraine and the zone of military occupation.

The study of the impact of German information policy on the population of the occupied territories and its behavior on propaganda depended on the following factors: different nature of German propaganda depending on the period of the war and the territory in which it took place; the strengthening or weakening of Nazi propaganda also depended on the activity of Soviet counter-propaganda; attitude of the population of Ukraine to the Soviet regime, formed in the pre-war period and at the beginning of the war.

Thus, it is impossible to determine the influence of the information space on the consciousness of the population of the Reich Commissariat of Ukraine and the zone of military administration quantitatively, faster by the state of the population and their occupation. In Western Ukraine, for example, the intelligentsia and the military, mostly concerned with the idea of creating an 
independent state, were ready to cooperate and seek their own. In the central and eastern regions of Ukraine, the intelligentsia, while trying to survive in difficult circumstances, only partially supported the occupying power. The rural population was influenced by Nazi propaganda only because they believed in the destruction of the collective farm system, the acquisition of their own land, and the ability to have an independent farm. It seemed to a very small part of the population that Germany, as a European country, would help Ukraine to raise economic and social development and elevate culture to a high stage, but these ideas were quickly dispelled by the genuine Third Reich policy.

It must be acknowledged that Nazi propaganda in the Reich Commissariat of Ukraine and in the area of military administration really contributed to the creation of a technologically powerful information space, in the formation of which the most modern mechanisms, means and methods of dissemination of information to the population were used at that time. The influence of this space is confirmed by the fact that some part of Ukrainian society really cooperated with the German occupation administration. But this collaboration was different in level and category. 


\section{LIST OF CONDITIONAL ABBREVIATIONS}

VKP (b) - Viskrievijas komunistiskā partija (boḷševiki).

Komjaunatne ir visas Krievijas L,enina komunistiskās jaunatnes savienība.

ZhSU - Ukrainas sieviešu dienests.

NKVD - Iekšlietu tautas komisariāts.

NKDB - Valsts drošības tautas komisariāts.

OUN - Ukrainas nacionālistu organizācija.

OUN-B - Ukrainas nacionālistu organizācija, kuru vada S. Bandera.

OUN-M - Ukrainas nacionālistu organizācija, kuru vada A. Melniks.

PFT - testēšanas un filtrācijas nometnes.

RNS - Tautas komisāru padome.

ROA - Krievijas atbrīvošanas armija.

CCU - Reiha komisariāts "Ukraina".

RSFSR - Krievijas Padomju Federatīvā Sociālistiskā Republika.

SA - Vācijas Nacionālsociālistu partijas uzbrukuma vien̄̄bas.

SD - nacistu slepenais drošības dienests, SS izlūkdienests.

SPD - Vācijas Sociāldemokrātiskā partija.

Smersh - Padomju pretizlūkošanas nodaḷa "Nāve spiegiem".

NVS - vācu meiteņu savienība.

SS ir Vācijas Nacionālsociālistu partijas elites drošības vienība.

UVO - Ukrainas militārā organizācija.

UNKVD - Iekšlietu tautas komisariāta birojs.

UNKDB - Valsts drošības tautas komisariāta birojs.

UNS - Ukrainas tautas pašaizsardzība.

UPA - Ukrainas nemiernieku armija.

PSRS - Ukrainas Padomju Sociālistiskā Republika.

CP (B) U Centrālā komiteja ir Ukrainas Komunistiskās partijas (boḷševiku) Centrālā komiteja.

PSKP Centrālā komiteja ir Padomju Savienības Komunistiskās partijas Centrālā komiteja. 
NOTES 
NOTES 
Publishing house "Liha-Pres"

9 Kastelivka str., Lviv, 79012, Ukraine 44 Lubicka str., Toruń, 87-100, Poland

Printed by the publishing house "Liha-Pres"

Passed for printing: August 25, 2020.

A run of 150 copies. 